\title{
World Nonbauxite Aluminum Resources Excluding Alunite
}

U.S. GEOLOGICAL SURVEY PROFESSIONAL PAPER 1076-O
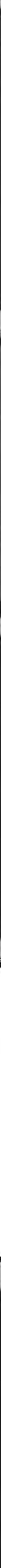
COVER PHOTOGRAPHS

\begin{tabular}{|c|c|c|c|c|}
\hline 1 & 2 & 3 & 4 & $\begin{array}{l}\text { 1. Asbestos ore } \\
\text { 2. Lead ore, Balmat Mine, N. Y. }\end{array}$ \\
\hline \multirow[t]{2}{*}{5} & & 6 & & 3. Chromite-chromium ore, Wash. \\
\hline & 7 & & 8 & 5. Banded iron formation, Palmer, \\
\hline 9 & & 10 & & 6. Ribbon asbestos ore, Quebec, Canada \\
\hline 11 & 12 & 13 & 14 & $\begin{array}{l}\text { 7. Manganese ore, banded } \\
\text { rhodochrosite }\end{array}$ \\
\hline
\end{tabular}

8. Aluminum ore, bauxite, Georgia

9. Native copper ore, Keweenawan Peninsula, Mich.

10. Porphyry molybdenum ore, Colo.

11. Zinc ore, Edwards, N. Y.

12. Manganese nodules, ocean floor

13. Botryoidal fluorite ore. Poncha Springs, Colo.

14. Tungsten ore, North Carolina 


\section{World Nonbauxite Aluminum Resources Excluding Alunite}

By JOHN W. HOSTERMAN, SAM H. PATTERSON, and ELIZABETH E. GOOD

G E O L O G Y A N D RE S O U R C E S O F A L U M I N U M

U.S. GEOLOGICAL SURVEY PROFESSIONAL PAPER 1076-C

A compilation of published information on the geology and worldwide distribution of nonbauxite resources that are potential sources of aluminum and on methods for extracting alumina from them

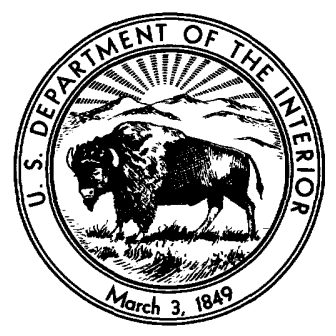




\title{
DEPARTMENT OF THE INTERIOR
}

MANUEL LUJAN, Jr., Secretary

\section{U.S. GEOLOGICAL SURVEY}

Dallas L. Peck, Director

\begin{abstract}
Any use of trade, product, or firm names in this publication is for descriptive purposes only and does not imply endorsement by the

U.S. Government
\end{abstract}

\section{Library of Congress Cataloging in Publication Data}

Hosterman, John W. (John Wallace), 1923-

World nonbauxite aluminum resources excluding alunite / by John W. Hosterman, Sam H. Patterson, and Elizabeth E. Good.

p. $\quad$ cm.-(U.S. Geological Survey professional paper ; 1076-C)

Includes bibliographical references.

Supt. of Does. no.: I 19.16:1076-C

1. Aluminum ores. 2. Aluminum ores-United States. I. Patterson, Sam H. (Sam Hunting). II. Good, Elizabeth E. III.

Title. IV. Series.

TN490.A5H67 1990

$553.4^{\prime} 926-\mathrm{dc} 20$

For sale by the Books and Open-File Reports Section, U.S. Geological Survey, Federal Center, Box 25425, Denver, CO 80225 


\section{CONTENTS}

Abstract

Introduction.......

History of Research on Nonbauxite Aluminum Resources in the United States.

Investigations by the U.S. Geological Survey

Investigations by the U.S. Bureau of Mines

Investigations by State Geological Surveys

Nonbauxite Aluminum Resources

High-Alumina Clay

United States.

Arkansas

South Carolina-Georgia-Alabama Kaolin Belt...... Argentina

Australia

Austria

Brazil

Bulgaria

Czechoslovakia

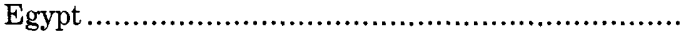

Federal Republic of Germany

France

German Democratic Republic

Guyana and Suriname.

India

Jamaica .

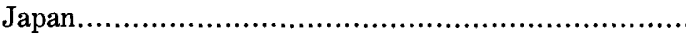

Pakistan

People's Republic of China

Saudi Arabia

South Africa

Spain.....

Tanzania and Other Countries in Africa ....................

United Kingdom.

U.S.S.R.

Aluminous Igneous Rocks-Anorthosite .....................

United States.

Canada

Finland .....

Greenland.

Norway....

South Korea

Sweden.....

U.S.S.R.

Other Countries

Aluminous Igneous Rocks-Nepheline Syenite and

Phonolite.

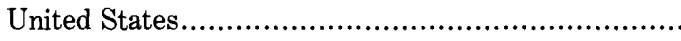

Canada

Egypt

Mexico

Norway.....

South Africa

United Kingdom

U.S.S.R.

Other Countries

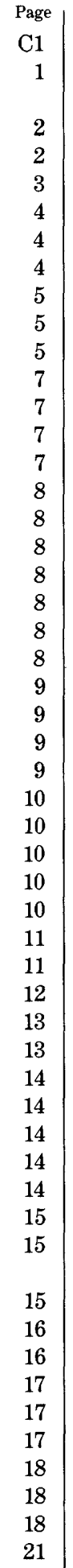

Nonbauxite Aluminum Resources-Continued

Aluminous Igneous Rocks-Leucite-Bearing Rocks ......... C21

Dawsonite-Bearing Rocks .................................... 21

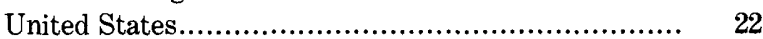

Geology ............................................ 22

Resources.............................................. 25

Other Countries ............................................ 25

Aluminous Phosphate Rocks................................. 26

United States................................................... 26

Senegal .................................................... 26

Other Countries ......................................... 27

Saprolite .......................................................... 27

United States.............................................. 28

Southeastern United States......................... 28

Arkansas................................................. $\quad 29$

Oklahoma ............................................. 29

Northwestern United States......................... 29

Hawaii ................................................... 29

Other Countries ....................................... 30

Aluminous Metamorphic Rocks ............................ $\quad 30$

United States............................................ 31

Canada ................................................... 31

Finland, Sweden, and Norway .......................... 32

India ...................................................... 32

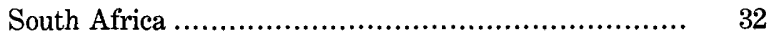

U.S.S.R............................................... 33

Zimbabwe .............................................. 33

Other Countries ............................................ 33

Aluminous Shale ............................................ 34

United States............................................. 34

Canada .................................................. $\quad 35$

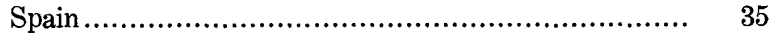

Sweden ..................................................... 35

Other Countries ......................................... 36

Coal Waste and Coal Ash...................................... 36

United States.............................................. 36

Canada ....................................................... 37

United Kingdom ............................................ 37

Other Countries ....................................... 37

Miscellaneous Sources of Alumina.............................. 37

Copper Leach Solutions .................................. 37

Gibbsitic Soils ........................................... 38

Zunyite................................................... 38

Alumina Extraction Research ...................................... 38

Research Before World War II ................................. 38

U.S. Research During World War II ........................ 39

Investigations by U.S. Government Agencies after

World War II......................................... 40

U.S. Bureau of Mines........................................ 40

Miniplant Studies....................................... 40

Other Studies........................................ 41

U.S. Department of Energy ............................. 42

U.S. Environmental Protection Agency ................... 42

U.S. Atomic Energy Commission ........................... 42 
Alumina Extraction Research-Continued

Investigations by U.S. Government Agencies after World War II-Continued

U.S. National Bureau of Standards....................... C43

Tennessee Valley Authority .............................. 43

Investigations by Companies ................................... 43

Aluminum Company of America .......................... 43

Anaconda Aluminum Company-Atlantic Richfield Company.

Kaiser Aluminum and Chemical Corporation

Reynolds Metals Company

Olin Mathieson Chemical Corporation.

Aluminium Pechiney

Alcan International, Ltd.

Toth Aluminum Corporation.

North American Coal Corporation

Allied Chemical Corporation.

Arthur D. Little, Inc

Kennecott Copper Corporation

Alumet

Other Companies

Investigations by U.S. Colleges and Universities

Investigations of U.S. Dawsonite

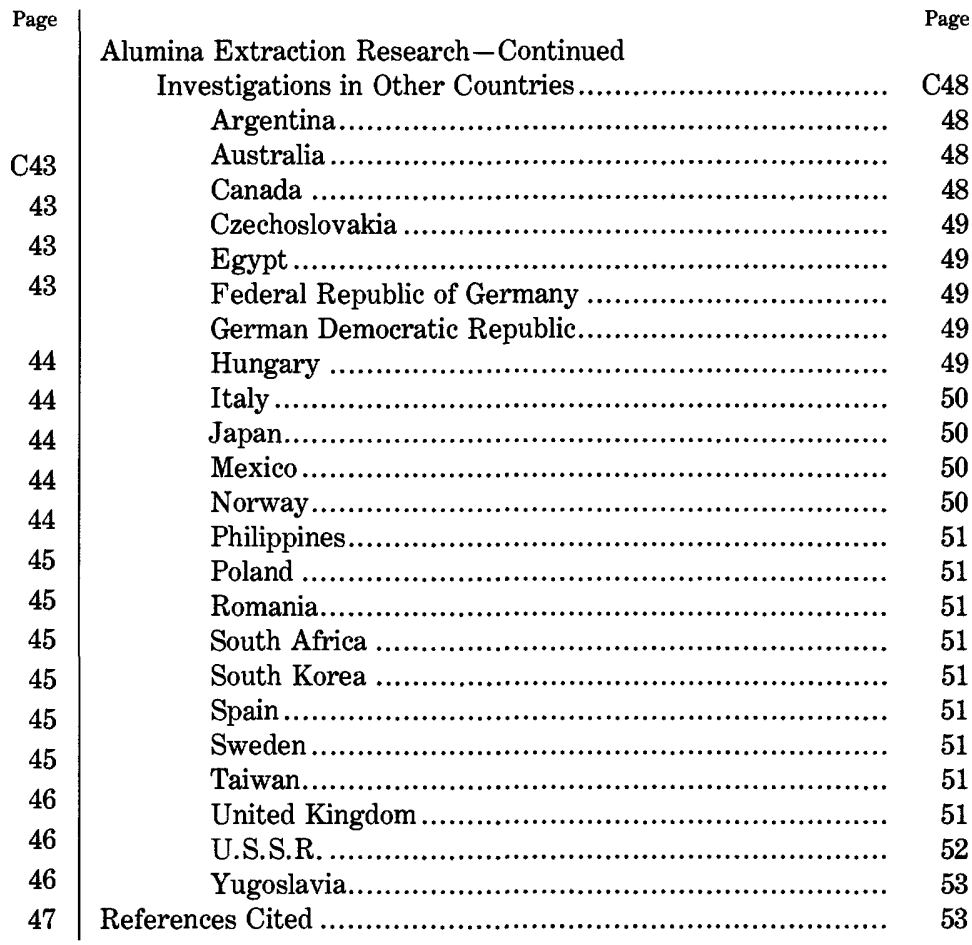

\section{ILLUSTRATIONS}

Figures 1-5. Maps showing locations of:

1. Six major kaolin districts in the South Carolina-Georgia-Alabama kaolin belt

2. Major anorthosite deposits in the United States

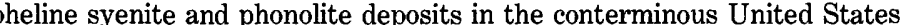

4. Nepheline syenite deposits in Ontario and Quebec Provinces, Canada ........

5. Major nepheline syenite deposits in the U.S.S.R., Finland, and Norway

6. Map showing the distribution of nahcolite and dawsonite in the Parachute Creek Member of the Green River Formation, Piceance Creek basin, northwestern Colorado.

7. Diagrammatic cross section through the Green River Formation in the Piceance Creek basin, northwestern Colorado.....

\section{TABLES}

TABLE 1. Nonbauxite aluminum resources used by Japan during World War II

2. Clays that are derived from Pleistocene volcanic ash and that may be a source of alumina in Japan-

3. Major aluminum-bearing materials in the United Kingdom

4. Chemical composition of some U.S. anorthosites

5. Major anorthosite bodies in the United States

6. Nonbauxite sources of alumina in Canada

7. Mineral composition of nepheline syenite

8. Chemical composition of nepheline syenite from Canada, Norway, and Scotland-

9. Major nepheline syenite and phonolite deposits in the United States

10. Mineral composition of samples from four sections of the Parachute Creek Member of the Green River Formation, Piceance Creek basin, northwestern Colorado 
11. Chemical analyses of seven samples from the aluminum phosphate zone in the Bone Valley Formation, Florida --_-_-_-_-_.- C27

12. Chemical composition ranges of saprolite from Spokane County, Washington-

13. Characteristics of the kyanite-group minerals - 30

14. Typical composition of anthracite culm in Pennsylvania -

15. Ranges in composition of coal-washing rejects in Kentucky and Pennsylvania - 44

\section{METRIC CONVERSION FACTORS}

This report uses the metric units listed below. To convert to inch-pound units, use the conversion factors given below.

\begin{tabular}{rll}
\hline Multiply & \multicolumn{1}{c}{ By } & To obtain \\
\hline centimeter $(\mathrm{cm})$ & 0.3937 & inch \\
meter $(\mathrm{m})$ & 3.281 & foot \\
kilometer $(\mathrm{km})$ & .6214 & mile \\
hectare $(\mathrm{ha})$ & 2.471 & acre \\
liter $(\mathrm{L})$ & .3861 & square mile \\
square kilometer $\left(\mathrm{km}^{2}\right)$ & 1.057 & quart \\
gram $(\mathrm{g})$ & 1.308 & cubic yard \\
metric ton & .03527 & ounce \\
cubic meter $\left(\mathrm{m}^{3}\right)$ & 1.102 & short ton $(2,000$ pounds $)$ \\
degree Celsius $\left({ }^{\circ} \mathrm{C}\right)$ & 1.8 and add 32 & degree Fahrenheit \\
kilojoule per kilogram $(\mathrm{kJ} / \mathrm{kg})$ & .4299 & British thermal unit per pound \\
\hline
\end{tabular}





\title{
WORLD NONBAUXITE ALUMINUM RESOURCES EXCLUDING ALUNITE
}

\author{
By John W. Hosterman, Sam H. Patterson, and Elizabeth E. Good
}

\begin{abstract}
The nonbauxite resources having the best potential for extraction of aluminum are alunite, high-alumina clay, and aluminous igneous rocks; those having less potential are dawsonite-bearing rocks, aluminous phosphate rocks, saprolite, aluminous metamorphic rocks, aluminous shale, coal waste, and coal ash. With the exception of alunite, which was discussed in the separately published Chapter A of this Professional Paper, all these resources are discussed in this report.

The high-alumina clays are composed of minerals of the kaolin group-kaolinite, halloysite, dickite, and nacrite. Kaolinite is by far the most abundant, and it is the major component in a variety of highalumina clays. High-alumina clays have a maximum alumina content of about 39 weight percent. However, no large deposits are pure, and most high-alumina clay deposits are $25-35$ weight percent alumina.

Igneous rocks exceptionally rich in alumina include anorthosite, nepheline syenite, phonolite, and leucite-bearing volcanic rocks. U.S. anorthosite contains 24-33 weight percent alumina, U.S. nepheline syenite contains 17-23 weight percent alumina, and Italian leucitebearing rocks contain 20-22 weight percent alumina.

The mineral dawsonite, which contains 35.4 weight percent alumina, occurs in oil shale but makes up no more than 12-25 weight percent of the rock. Therefore, any aluminum production from dawsonite must depend upon other products from the shale such as oil and soda ash derived from nahcolite.

The aluminous phosphate rock associated with phosphate deposits is the result of calcium phosphate being leached by meteoric waters. The alumina content of such phosphate rock in the United States ranges from about 6 to 15 weight percent, and the aluminum phosphate minerals make up 20-30 weight percent of the rock. Any aluminum production from this rock will depend on the recovery of other products such as phosphate and uranium. The Thiès region, Senegal, is the only place in the world where significant tonnages of aluminum phosphate are mined.

Saprolite is a decomposed rock formed in place by subaerial chemical weathering of any kind of rock; it retains the original structure and texture of the parent rock. Some saprolite is similar in chemical and mineral composition to high-alumina clay, and some saprolite contains gibbsite replacing kaolinite. Generally, saprolite that is a potential resource of alumina contains 20-38 weight percent alumina.

Aluminous metamorphic rocks contain the minerals kyanite, sillimanite, andalusite, topaz, or dumortierite. These minerals contain 55-64
\end{abstract}

Manuscript approved for publication, November 3, 1989. weight percent alumina. Aluminous metamorphic rocks may contain as much as 40 weight percent kyanite-group minerals, but generally they contain less than 15 weight percent.

Aluminous shales are sedimentary rocks formed by the consolidation of clay- and silt-sized material. Almost all shales contain some quartz and the clay minerals illite, kaolinite, and (or) smectite. The alumina content of shale that is a potential resource of alumina ranges from 20 to 40 weight percent.

Aluminous coal waste includes the claystone and shale removed from the coal during beneficiation by washing and shale or slate above the coal that is removed during the mining. Fly ash, the fine material, and other forms of ash collected from a coal-burning powerplant's combustion system are also aluminous and are potential sources of alumina. Some of these materials have an alumina content of about 30 weight percent, and because of the enormous amount of coal mined and burned annually, they represent a large potential resource of alumina.

Miscellaneous sources of alumina include copper leach solutions that have been used to extract copper from many of the porphyry copper mining operations. The U.S. Bureau of Mines estimated, before the closing of many U.S. copper mines, that 500,000 metric tons of alumina per year could have been produced in the United States from copper leach solutions. Other materials that have been considered sources of alumina are the gibbsitic soils of the U.S. Atlantic and Gulf of Mexico Coastal Plains and zunyite in Nevada. There are no estimates on the amount of alumina that these materials would yield.

None of the potential resources of aluminum are being exploited today in the United States. Currently, U.S. needs for alumina are met by bauxite from Arkansas and from imports.

\section{INTRODUCTION}

This report provides information on potential nonbauxite aluminum resources excluding alunite. It is the third, and last, of a series of reports on the resources of aluminum. These reports are separately published by the U.S. Geological Survey as Professional Papers 1076-A, $\mathrm{B}$, and $\mathrm{C}$. World bauxite resources were summarized in Chapter B (Patterson and others, 1986), and alunite resources were summarized in Chapter A (Hall, 1978). These three reports were prepared in response to the increasing demands for information on world aluminum resources that have resulted from the increased depend- 
ence of the United States on foreign sources for bauxite. Domestic reserves of bauxite are not sufficient to supply U.S. aluminum needs; therefore, the United States must rely on imports of bauxite, alumina $\left(\mathrm{Al}_{2} \mathrm{O}_{3}\right)$, and aluminum until the production of aluminum from nonbauxite sources becomes economical. This report, which emphasizes the United States, summarizes published information on the worldwide distribution and geology of materials containing sufficient alumina to be considered alternate sources of alumina were bauxite to become unavailable.

The nonbauxite resources (excluding alunite) having the best potential for extraction of alumina are highalumina clay and aluminous igneous rocks; those having less potential are dawsonite-bearing rocks, aluminous phosphate rocks, saprolite, aluminous metamorphic rocks, aluminous shale, coal waste, and coal ash. Highalumina clay is any clay containing an appreciable amount of aluminum that can be extracted as alumina. The common clay minerals that are high in alumina are members of the kaolin group, and the terms "kaolin" and "high-alumina clay" are used interchangeably. Igneous rocks exceptionally rich in aluminum include anorthosite, nepheline syenite, phonolite, and leucite-bearing volcanic rocks. Dawsonite, a hydrous sodium and aluminum carbonate mineral that contains 35.4 weight $^{1}$ percent alumina or 18.7 percent aluminum, is in the oil shale of the Green River Formation in Colorado. Aluminous phosphate rocks are the result of leaching and alteration by meteoric waters of phosphate deposits. Saprolite is a decomposed product of subaerial chemical weathering of any kind of rock in place; its principal aluminous minerals are of the kaolin group. Aluminous metamorphic rocks contain the kyanite-group minerals (kyanite, sillimanite, andalusite, topaz, and dumortierite), which contain 55-64 percent alumina. Aluminous shale and alum shale are fine-grained sedimentary rocks that contain enough alumina (20-40 percent) to be considered a potential resource. The recovery of alumina from coal waste and coal ash has received attention in many countries because the alumina content can be about 30 percent and because so much of this material is available. Alunite is mentioned only briefly in this report because it was discussed in detail by Hall (1978).

This report begins with a brief history of investigations of U.S. nonbauxite aluminum resources. The main part of the report is a discussion of each resource and the worldwide distribution of its potentially economic deposits. The last part of this report is a partial compilation of the enormous amount of research done to find the best method for extracting alumina from nonbauxite material. After a brief history, this compilation is organized by

\footnotetext{
${ }^{1}$ All percentages are by weight unless otherwise specified.
}

investigator, such as U.S. government agencies, U.S. and international companies, and U.S. colleges and universities. The compilation ends with a summary of extraction research in other countries. Our expertise is in geology, not metallurgy, but we gathered the scattered extraction data to provide future researchers with a background on the work available as a basis for further experiments.

\section{HISTORY OF RESEARCH ON NONBAUXITE ALUMINUM RESOURCES IN THE UNITED STATES}

\section{INVESTIGATIONS BY THE U.S. GEOLOGICAL SURVEY}

High-alumina clay.-The U.S. Geological Survey (USGS) investigated many high-alumina clay deposits during World War II, including those in the following areas:

Cowlitz County, Washington (Nichols, 1945);

King County, Washington (Nichols, 1946);

Spokane County, Washington (Scheid, 1946, 1947; Hosterman and others, 1960);

Molalla, Clackamas County, Oregon (Nichols, 1944);

Hobart Butte, Lane County, Oregon (Allen and others, 1951);

Latah County, Idaho (Scheid and Sohn, 1946; Hosterman and others, 1960);

Clearfield County, Pennsylvania (Foose, 1944); and Allegany and Garrett Counties, Maryland (Waagé, 1950).

During and after World War II, the USGS also investigated high-alumina clay deposits associated with bauxite in the Southern and Southeastern States in the following areas:

Pulaski and Saline Counties, Arkansas (Tracey, 1944; Gordon and others, 1958);

Tippah-Benton district, Mississippi (Tourtelot, 1964);

parts of eastern Mississippi exclusive of the TippahBenton district (Conant, 1965);

Margerum district, Alabama (Bergquist and Overstreet, 1965);

northeastern Alabama (Denson and Waagé, 1966);

Anniston, Fort Payne, and Ashville areas, Alabama (Cloud, 1966);

Rock Run and Goshen Valley areas, Alabama (Cloud, 1967);

Eufaula district, Alabama (Warren and Clark, 1965); northwestern Georgia (White and Denson, 1966); Warm Springs district, Georgia (White, 1965); Springvale district, Georgia (Clark, 1965);

Andersonville district, Georgia (Zapp, 1943, 1949, 1965); 
areas adjacent to and between the Springvale and Andersonville districts, Georgia (Zapp and Clark, 1965);

Irwinton district, Georgia (Warren, 1943; Thompson, 1944a, b; Lang and others, 1965);

central and eastern Tennessee (Dunlap and others, 1965); and

western Virginia (Warren and others, 1965).

After World War II, the USGS investigations of high-alumina clay continued in the following areas:

eastern Washington (Hosterman, 1969a);

Front Range, Colorado (Waagé, 1953, 1961);

Jackson Purchase region, Kentucky (Olive and Finch, 1969);

eastern Kentucky (Huddle and Patterson, 1961; Patterson and Hosterman, 1962);

Andersonville district, Georgia (Cofer and others, 1976; Cofer and Manker, 1983);

Macon-Gordon area, Georgia (Buie and others, 1979); and

Mount Holly Springs, Pennsylvania (Hosterman, 1969b, 1984).

The USGS published a map of alumina resources in the Columbia River Basin, Northwestern United States (Sohn, 1952), and a map and bibliography of high-alumina clay deposits in the United States exclusive of Alaska and Hawaii (Mark, 1963). Murray and Patterson (1976) summarized kaolin, ball-clay, and fire-clay resources in the United States and later expanded their study area when they (Patterson and Murray, 1984) summarized kaolin, refractory-clay, ball-clay, and halloysite resources in North America, Hawaii, and the Caribbean region.

Aluminous phosphate rocks. - The work by the USGS on aluminous phosphate deposits consisted of chemical and mineralogical investigations (Altschuler and others, 1956) and geologic studies (Cathcart and Houser, 1950; Cathcart and others, 1953; McKelvey and others, 1953; Cathcart, 1963; Espenshade and Spencer, 1963).

Aluminous igneous rocks. -The USGS also studied the resources of the igneous rocks that have been considered potential sources of alumina. The earliest work included study of nepheline-bearing rocks in the Little Belt Mountains, Montana (Weed and Pirsson, 1900); potash-bearing rocks in the Leucite Hills, Wyoming (Schultz and Cross, 1912); phonolite in the Black Hills, South Dakota (Darton and Paige, 1925); and anorthosite near Chester, Pennsylvania (Bascom and Stose, 1938). The more recent work includes reports on the anorthosite deposits in northern Idaho (Hietanen, 1963); the Stillwater Complex, Montana (Jones and others, 1960); the Laramie Range, Wyoming (Hagner, 1951; Newhouse and Hagner, 1957); and Roseland, Virginia (Herz, 1968; Herz and Force, 1984).
Nepheline syenite occurrences were studied in the following areas:

Selawik Hills, Alaska (Patton and Miller, 1968; Miller, 1972);

Granite Mountain, Alaska (Miller, 1972);

St. Lawrence Island, Alaska (Csejtey and Patton, 1974);

Shasket Creek, Washington (Parker and Calkins, 1964);

Lincoln County, Oregon (Snavely and Wagner, 1961);

Tin Mountain, Inyo County, California (McAllister, 1952);

Bearpaw Mountains, Montana (Pecora, 1942; Hearn and others, 1964);

McClure Mountain, Colorado (Parker and Hildebrand, 1963);

Cornudas Mountains, New Mexico (Holser, 1959);

Terlingua district, Big Bend area, Texas (Yates and Thompson, 1959);

Arkansas bauxite district (Gordon and others, 1958); and

Magnet Cove, Arkansas (Erickson and Blade, 1963).

Dawsonite-bearing rocks. - USGS studies of dawsonite from the Piceance Creek basin, Colorado, as a soure of aluminum include those by Donnell (1961), Hite and Dyni (1967), Dyni and Hite (1968), Hosterman and Dyni (1972), Dyni $(1974,1980)$, and Donnell and Smith (1980). USGS research resulted in two U.S. patents for extracting alumina from dawsonite in oil shale (Hite, 1969; Dyni, 1972); they were assigned to the Secretary of the Interior.

\section{INVESTIGATIONS BY THE U.S. BUREAU OF MINES}

The U.S. Bureau of Mines (USBM) and the USGS conducted many joint and separate investigations of nonbauxite aluminum resources during World War II. Most of this work was on high-alumina clay, but anorthosite and alunite were also investigated. Much of the USBM's work on high-alumina clay resources was published in more than 450 War Minerals Reports between 1942 and 1945. In 1953, the USBM, with the cooperation of the USGS, prepared a materials survey on bauxite for the National Security Resources Board (U.S. Bureau of Mines, 1953). The report has a chapter on bauxite substitutes and includes numerous additional references on nonbauxite resources and the methods of alumina recovery used before and during World War II. The joint work by the USGS and USBM on the alunite deposits was summarized by Hall (1978).

An extensive drilling program by the USBM in the Arkansas bauxite region revealed that large highalumina clay deposits are associated with the bauxite. These data were published in 18 reports by Malamphy 
and others (1948). The USBM also conducted several drilling projects in the South Carolina-Georgia-Alabama kaolin belt during the 1940's (Allen, 1949; Beck, 1949a-c; K.IM. Smith, 1949). The USBM contracted for the Georgia Institute of Technology to determine the alumina content of 120 kaolin samples from company drill holes in Georgia; 79 samples were from the Wrens district, 40 were from the Macon-Sandersville district, and 1 sample was from the Andersonville district (Husted, 1983).

The USBM did extensive work, both resource research and extraction research, on the anorthosite deposits of the Laramie Range, Wyoming (St. Clair and others, 1959), and of the San Gabriel Mountains, California (Lundquist, 1963). Much of what is presently known of the potential aluminum resource of dawsonite in the Piceance Creek basin, Colorado, was compiled by the USBM (J.W. Smith and Milton, 1966; J.W. Smith and Young, 1969, 1975; J.W. Smith and others, 1972; Beard and others, 1974; Beard and Smith, 1976; J.W. Smith, 1980). Other nonbauxite sources of aluminum investigated by the USBM include saprolite (Beg, 1982, 1984), coal-mine waste (Sorensen and Schaller, 1983), and copper leach solutions (George and others, 1968).

\section{INVESTIGATIONS BY STATE GEOLOGICAL SURVEYS}

Several State geological surveys have investigated the nonbauxite aluminum resources in their respective States. The Geological Survey of Alabama studied kaolin associated with bauxite in the Eufaula district (Clarke, 1972), kaolin in the Tuscaloosa Group (Clarke, 1964), and gibbsite in saprolite (Beg, 1984) and mapped the aluminous waste dumps that result from strip mining coal in Tuscaloosa County (Beg and others, 1978). The North Dakota Geological Survey investigated the alumina potential of three formations in the western part of the State (Hansen, 1959).

Other State geological surveys that have investigated high-alumina clays include those in the States listed below:

\begin{tabular}{|c|c|}
\hline State & Reference \\
\hline Arkansas . & Williams and Plummer, 1951. \\
\hline California. & Cleveland, 1957a, b. \\
\hline Florida.. & Calver, 1949. \\
\hline Georgia & $\begin{array}{l}\text { Smith, 1929; Munyan, 1938; Hetrick, 1982; Hetrick } \\
\text { and Friddell, 1982, 1983a, b. }\end{array}$ \\
\hline Illinois . & $\begin{array}{l}\text { Grim and Allen, 1938; Lamar, 1948; White, 1959; } \\
\text { Odom and Parham, } 1968 .\end{array}$ \\
\hline Kansas. & Plummer and Romary, 1947. \\
\hline Kentucky & Crider, 1913. \\
\hline Maryland. & Waagé, 1950. \\
\hline Minnesota & Parham, 1970. \\
\hline Missouri. . & McQueen, 1943. \\
\hline Nebraska. & Gould and Fisher, 1901. \\
\hline New York. & Brownell and others, 1951. \\
\hline North Caroli & Parker, 1946. \\
\hline
\end{tabular}

\begin{tabular}{|c|c|}
\hline State-Continued & Reference-Continued \\
\hline Ohio & Stout and others, 1923. \\
\hline Penn & $\begin{array}{l}\text { Leighton, 1941; Bolger and Weitz, 1952; Pennsyl- } \\
\text { vania Geological Survey, 1964; O'Neill and oth- } \\
\text { ers, 1965; Hoover and others, } 1971 \text {. }\end{array}$ \\
\hline Soutr & Gries, 1942; Rothrock, 1944. \\
\hline Virginia.. & $\begin{array}{l}\text { Calver, Hamlin, and Wood, 1961; Calver, Smith, } \\
\text { and LeVan, 1964; Johnson and others, 1965; } \\
\text { Johnson and Tyrrell, 1967; Sweet, } 1973 .\end{array}$ \\
\hline Wash & Glover, 1941; Livingston, 1971. \\
\hline We: & Tallon and Hunter, 1959. \\
\hline
\end{tabular}

The Minnesota Geological Survey (Grout and Schwartz, 1939) and the Wyoming Geological Survey (Hagner, 1951) published reports on the anorthosite deposits within their respective States. The Illinois Geological Survey made a comprehensive review of the literature on fly ash (Roy and others, 1981) and proposed a classification system that should aid in research efforts and environmental control.

Research on processes for the extraction of alumina from clays has also been done by some State geological surveys. The Illinois Geological Survey investigated the lime and lime-soda sinter processes for the extraction of alumina from several types of clay minerals (Grim and others, 1945). Two different processes for the extraction of alumina from clays in Kansas were investigated by the Kansas Geological Survey (Kinney, 1943; Waugh and others, 1964).

The State of Georgia offered an award of $\$ 250,000$ to the first company to build an alumina-extraction plant to process 300,000 metric tons per day from the large kaolin deposits within the State (Metals Sourcebook, 1974).

\section{NONBAUXITE ALUMINUM RESOURCES}

\section{HIGH-ALUMINA GLAY}

High-alumina clay is any clay containing an appreciable amount of aluminum that can be extracted as alumina. The common clay minerals that are high in alumina are members of the kaolin group, and the terms "kaolin" and "high-alumina clay" are used interchangeably. Kaolinite, $\mathrm{Al}_{2} \mathrm{Si}_{2} \mathrm{O}_{5}(\mathrm{OH})_{4}$, has a theoretical composition of $\mathrm{Al}_{2} \mathrm{O}_{3}, 39.5$ percent; $\mathrm{SiO}_{2}, 46.5$ percent; and $\mathrm{H}_{2} \mathrm{O}, 14.0$ percent; it is by far the most common mineral of the kaolin group. The other minerals in the kaolin group, not discussed in any detail here, are halloysite, dickite, and nacrite.

Kaolinite is the major constituent in a variety of high-alumina clays, such as ball clay, fire clay, and underclay. Ball clay is a secondary clay that contains organic matter, is highly plastic, has a high dry strength and long vitrification range, and is light colored when fired. Fire clay is resistant to heat at temperatures as 
high as $1,520^{\circ} \mathrm{C}$ and is usually slightly darker than ball clay when fired. Underclay normally underlies a coal or peat bed. Underclay is generally nonbedded and slickensided, fractures irregularly, and contains imprints of plant roots. Underclay is also called "seat earth" in England and is very similar to the material called "Tonstein" in German.

High-alumina clays in one form or another occur in most countries. In the following discussions, no attempt will be made to list or even summarize all of the world's high-alumina clay resources. Most of the discussions will be limited to those resources that have been investigated as potential sources of alumina or that are large enough to supply an alumina-extraction plant for many years. A realistic potential resource should contain at least 100 million metric tons of high-alumina clay.

\section{UNITED STATES}

The United States has many deposits of high-alumina clays. The extensive kaolin deposits in Arkansas and the kaolin belt of South Carolina, Georgia, and Alabama have by far the greatest potential for nonbauxite aluminum resources in the United States, and only they are discussed in this report. The Aluminum Company of America and Reynolds Metals Company own property in Arkansas, and four major aluminum companies control property in the South Carolina-Georgia-Alabama kaolin belt (Mining Journal, 1977). In both regions, the kaolin occurs in large areas that can be mined by inexpensive open-pit methods.

Many other high-alumina clay deposits throughout the United States are much smaller and lower grade and would probably be more costly to mine. During and after World War II, these deposits were investigated by the USGS and USBM as summarized above. Results were given in reports by Sohn (1952), the USBM (1953), Patterson (1967), Murray and Patterson (1976), Patterson and Murray (1984), and Hosterman (1984) and in other reports listed in the bibliography by Mark (1963).

\section{ARKansas}

The principal high-alumina clay deposits in Arkansas are associated with the bauxite deposits that fringe the buried nepheline syenite hills in Pulaski and Saline Counties (Gordon and others, 1958, p. 255). The bauxite bodies grade both laterally and vertically through bauxitic clay into the enclosing large masses of kaolin clay. These clays and the bauxite are a facies of the Berger Formation, the lower formation of the Wilcox Group of early Eocene age. The bauxite-kaolin zone attains a maximum thickness of $24 \mathrm{~m}$, but in most places, it does not exceed $18 \mathrm{~m}$. The typical kaolin zone in these deposits contains more than 35 percent $\mathrm{Al}_{2} \mathrm{O}_{3}$, less than 45 per- cent $\mathrm{SiO}_{2}$, and less than 5 percent $\mathrm{Fe}_{2} \mathrm{O}_{3}$. The clay is chiefly kaolinite, and the principal impurities are siderite, limonite, ilmenite, and carbonaceous material; biotite is common locally. According to a conservative estimate, the Arkansas bauxite region contains at least 100 million metric tons of kaolin that is covered by less than $15 \mathrm{~m}$ of overburden (Tracey, 1944); presumably, additional larger resources exist under greater thicknesses of overburden.

Numerous kaolin deposits also occur in a broad belt of Wilcox Group rocks extending southwest of the Arkansas bauxite region in parts of Grant, Hot Springs, Dallas, Ouachita, and Miller Counties (Williams and Plummer, 1951). The clay in this belt is in lenses ranging in thickness from $15 \mathrm{~cm}$ to $9 \mathrm{~m}$ and in areal extent from a few square meters to 16 ha or more. The clay lenses are enclosed by beds of chiefly unconsolidated sandstone, which contain appreciable quantities of lignite. Part of the clay is pure, and part is contaminated with silt, sand, and lignite. One sample examined by R.E. Grim consisted chiefly of kaolinite but also contained montmorillonite and quartz (Williams and Plummer, 1951, p. 6).

The Arkansas bauxite region and the belt of Wilcox Group rocks extending southwest of the bauxite region are estimated to contain 545 million metric tons of kaolin having an average alumina content of about 31 percent (U.S. Bureau of Mines, 1967, p. 38). This estimate is based on references cited in the foregoing two paragraphs and on the results of an extensive drilling program described in 18 U.S. Bureau of Mines Reports of Investigations (Malamphy and others, 1948).

South Carolina-Georgia-Alabama Kaolin Belt

The South Carolina-Georgia--Alabama kaolin belt extends for nearly $400 \mathrm{~km}$ from Aiken, S.C., to Eufaula, Ala. There are six major districts within this belt; from northeast to southwest, they are Augusta-Aiken, Wrens, Sandersville, Macon-Gordon, Andersonville, and Eufaula (fig. 1). All the kaolin deposits are in sedimentary rocks, and, except for a small outlier at Warm Springs, Ga., all are in the Coastal Plain. This belt is the world's leading producer of sedimentary kaolin, and more than 100 million metric tons of kaolin have been mined. Our description of this belt is derived mostly from that by Patterson and Murray (1984).

The resources of kaolin in the South CarolinaGeorgia-Alabama kaolin belt are estimated to be 7 billion-10 billion metric tons (Patterson and Murray, 1984, p. 7). This estimate may prove to be very conservative because meaningful estimates are available for only three of the six major districts in the kaolin belt.

The kaolin deposits in the South Carolina-GeorgiaAlabama belt are of Late Cretaceous and early Tertiary 


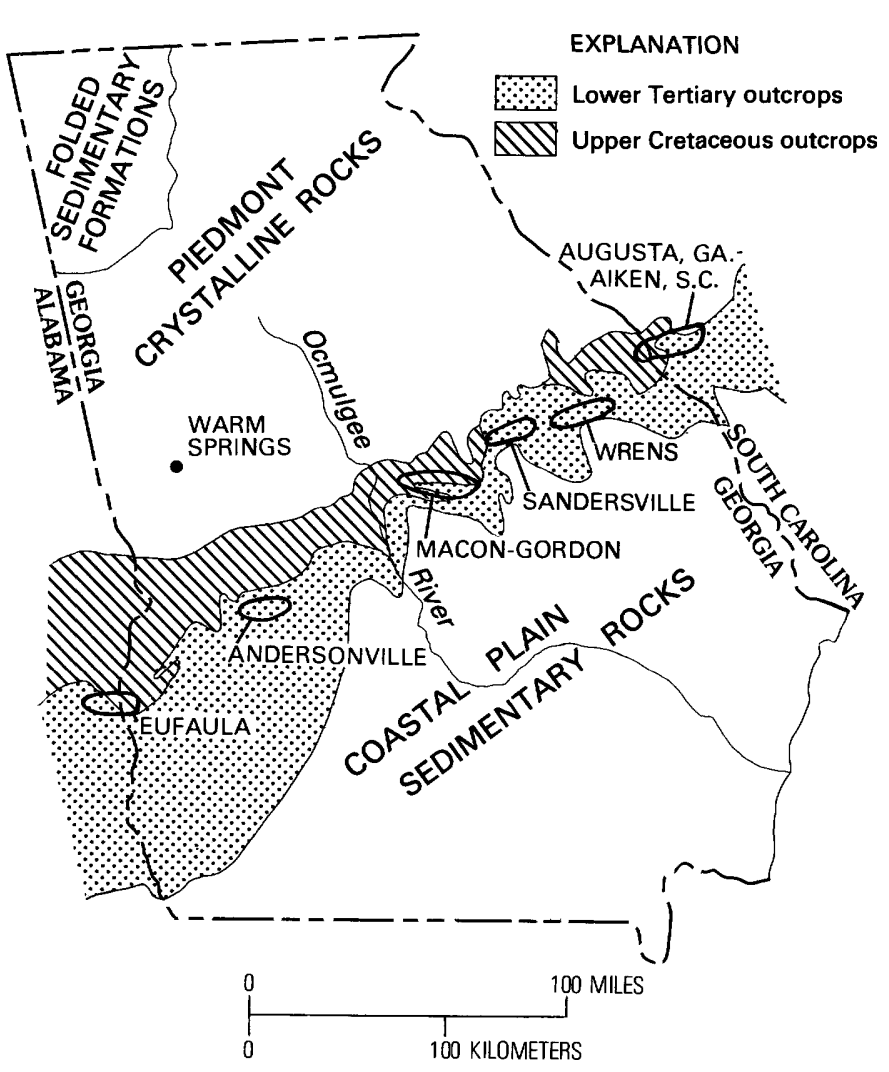

FIgURE 1.-Six major kaolin districts in the South CarolinaGeorgia-Alabama kaolin belt. Modified from Patterson and Murray (1984, fig. 3).

ages. Deposits of Late Cretaceous age occur in the Augusta-Aiken district, in the western part of the Sandersville district, and in the Macon-Gordon district. The kaolin deposits of this age are scattered throughout a wedge-shaped Upper Cretaceous sand unit that thickens downdip toward the ocean; more than $335 \mathrm{~m}$ of this unit was penetrated by a drill hole near Tarversville, Ga. (Buie and others, 1979, p. 8). Updip, the Upper Cretaceous sand unit is truncated by erosion.

Kaolin deposits of early Tertiary age, which are larger than the Upper Cretaceous deposits, occur in all six major districts (fig. 1). The Tertiary strata containing the kaolin are similar in lithology to the underlying Upper Cretaceous beds. The Cretaceous-Tertiary contact is unconformable, and at several localities, the Tertiary beds extend over pre-Cretaceous crystalline rocks.

Warm Springs district, Georgia. - The Warm Springs district contains small kaolin deposits dated as Paleocene by pollen studies (N.O. Frederiksen, oral commun., 1979). The deposits probably are mined out, and little is known about them other than that they were associated with small gibbsitic bauxite deposits in a downfaulted block of Tertiary sediments surrounded by crystalline rocks of the Piedmont region (White, 1965). The geographic location of the Warm Springs district strongly suggests that kaolin deposits were widespread north of Andersonville before extensive erosion of Tertiary and Upper Cretaceous beds.

Augusta, Ga.-Aiken, S.C., district.-Deposits in the Aiken district, South Carolina, were investigated by the U.S. Geological Survey (Lang and others, 1940), and 200 coreholes were drilled by the U.S. Bureau of Mines (K.M. Smith, 1949). Buie and Schrader (1982) completed more recent work in this district and found that most of the kaolin produced there is from the lower Tertiary Huber Formation, which is equivalent to the Claiborne Formation. Kaolin in the Augusta district, Georgia, was described by R.W. Smith (1929, p. 389-407). Resource estimates are not available.

Wrens district, Georgia.-The kaolin in the Wrens district is believed to be Eocene in age (Husted, 1983, p. 10). Husted (1983) estimated the kaolin under less than $55 \mathrm{~m}$ of overburden in the Wrens district to be 5.4 billion metric tons of material averaging 35.5 percent alumina. The study also revealed that the kaolin occurs as a single continuous body having an average thickness of $7.6 \mathrm{~m}$ and underlying $490 \mathrm{~km}^{2}$.

Sandersville district, Georgia.-The western part of the Sandersville district and the eastern part of the Macon-Gordon district were included in the Irwinton district of Lang and others (1965). This area also was studied by Warren (1943) and Thompson (1944a, b) and was drilled by the U.S. Bureau of Mines (Beck, 1949b). More recently, deposits in the Sandersville district were investigated by the Georgia Geologic Survey (Hetrick, 1982; Hetrick and Friddell, 1982, 1983a, b).

The commercial-grade kaolin in this district occurs in the Eocene Huber Formation and in the undifferentiated Cretaceous sediments (Hetrick and Friddell, 1983a). Resource estimates are not available.

Macon-Gordon district, Georgia.-Early studies of the Macon-Gordon district are mentioned under the Sandersville district above. More recent work has been done by Buie (1978), Buie and others (1979), and Husted (1983).

The lower Tertiary strata of the Macon-Gordon district are in the Huber Formation (Buie, 1978), which is typical of a tidal-flat environment of deposition. Channel-fill deposits are abundant, and most of the formation is intricately crossbedded. Ilmenite and other dark heavy minerals are abundant and are concentrated along bedding planes. Lignitic clays, which contain pollen, occur at many places, usually as single beds or as restricted lenses. Rounded boulders of pisolitic kaolin and gibbsitic kaolin, ranging in diameter from a few centimeters to more than $2 \mathrm{~m}$, are present in the upper part of the 
formation at many places. Many of these boulders are enclosed in sand, and they clearly indicate a high-energy environment of deposition.

Buie and others (1979, p. 31) estimated the total kaolin resources in the Macon-Gordon district to be greater than 100 million metric tons. Subeconomic resources were estimated to be an additional 700 million-900 million metric tons and undiscovered kaolin resources to be 700 million-1 billion metric tons. Accordingly, the total kaolin resources in the Macon-Gordon district are estimated to be 1.5 billion-2 billion metric tons.

Andersonville district, Georgia. -During World War II, the U.S. Geological Survey investigated kaolin and bauxite in the Andersonville district (Zapp, 1943, 1949, 1965), in the Springvale district (Clark, 1965), and in areas adjacent to and between the Springvale and the Andersonville districts (Zapp and Clark, 1965). The Springvale district, Georgia, is southwest of the Andersonville district. The U.S. Bureau of Mines drilled 1,192 coreholes in the Andersonville district (Beck, 1949a) and 388 coreholes in the Springvale district (Beck, 1949c). The kaolin deposits occur in the Paleocene Nanafalia Formation (N.O. Frederiksen, oral commun., 1979). The geology of the district was described by Cofer and Manker (1983).

A computerized study of approximately 2,500 drillhole records for the Andersonville district (Cofer and others, 1976, table 1) indicated reserves to be 290 million metric tons of kaolin containing 30-35 percent alumina. The study also indicated the presence of an equal amount of subeconomic sandy kaolin. Therefore, the total resource of kaolin was estimated to be 580 million metric tons.

Eufaula district, Georgia and Alabama.-During World War II, the U.S. Geological Survey (Warren and Clark, 1965) and the U.S. Bureau of Mines (Allen, 1949) investigated kaolin in the Eufaula district. The Geological Survey of Alabama (Clarke, 1972) and the refractories industry (Jones, 1972; Burst, 1974) also investigated the Eufaula district. The kaolin deposits occur in the Paleocene Nanafalia Formation (N.O. Frederiksen, oral commun., 1979). Resource estimates are not available.

\section{ARGENTINA}

Although information on the size of kaolin resources in Argentina is unavailable, kaolin deposits are known to occur at many places (N.I. Rosy, written commun., 1980). The deposits in central Neuquen Province apparently are the largest, and they were once considered to be the potential source of raw material for a proposed plant to extract alumina from kaolin (Engineering and Mining Journal, 1954). This kaolin is of sedimentary origin and was transported from a region of weathered basalt. Kaolin deposits in Chubut Province are also significant. The largest of these deposits consists of residual kaolin from pyroclastic volcanic rocks; other deposits were formed by hydrothermal alteration.

\section{AUSTRALIA}

Australia has many kaolin deposits. Gaskin (1969) listed the following occurrences: 36 in weathered granite and related rocks, 32 in kaolinized metamorphic rocks, 30 in kaolinized dike rocks, and 15 in kaolinized sedimentary rocks. Gaskin and others (1979) discussed the following six kaolin districts that presumably contain the most important kaolin deposits in Australia: (1) Gabbin, Western Australia, (2) Imbitch, South Australia, (3) Crawford, South Australia, (4) Gulong, New South Wales, (5) Pittong, Victoria, and (6) Egerton, Victoria. More recent work by Murray (1984) outlined very extensive kaolin deposits underlying the bauxite in the large Weipa district of Queensland. However, interest in recovering alumina from clay is unlikely to develop because Australia's bauxite reserves are measured in billions of metric tons.

\section{AUSTRIA}

The kaolin deposits of Austria occur on a deeply eroded and peneplained basement complex of granite and metamorphic rocks (Holzer and Wieden, 1969). The principal deposits occur at Kriechbaum and Weinzierl near the city of Schwertberg in Upper Austria and at Mallersbach and Niederfladnitz near the city of Retz in Lower Austria. These residual deposits formed by weathering, and they contain 35-45 percent kaolinite (Grim, 1979, p. 198). According to Vachtl $(1969$, p. 14), the kaolin resources of Austria are greater than 100 million metric tons. However, the small areas occupied by kaolinized rock (Holzer and Wieden, 1969, p. 27) make Vachtl's estimates suspect.

\section{BRAZIL}

Several large sedimentary kaolin deposits have been discovered in the Amazon Basin of Brazil (Souza Santos, 1976; Azevedo Branco, 1984). One district is along the Capim River about $240 \mathrm{~km}$ by road south of Belém, the capital of the State of Pará. It contains an estimated 560 million metric tons (Souza Santos, 1976). A second district is in Amapá Territory in the valley of the Jarí River, which flows into the Amazon River from the north. The kaolin in this district is presently being mined for use in the manufacture of paper and ceramics. Resources of kaolin in the Jarí district are estimated at 100 million metric tons (Souza Santos, 1976). The third district is at Ananindeua, near Belém, in Pará State. Approximately 
2 million metric tons of kaolin are mined there annually (Azevedo Branco, 1984). A reference clay sample (IPT28) from a deposit in this district contains 95 percent kaolinite and 5 percent quartz (Hosterman and others, 1987, p. 4). The large kaolin resources of the Amazon Basin have little foreseeable value as an alumina resource because of the large resources of bauxite that also are present.

\section{BULGARIA}

Numerous deposits of sandy kaolin in karst depressions occupy a total area of $3,000 \mathrm{~km}^{2}$ in northeastern Bulgaria between the towns of Russe and Varna (Manolov and others, 1969). Of the kaolin deposits, 30-60 percent are white, pale pink, and cream and contain less than 1.2 percent $\mathrm{Fe}_{2} \mathrm{O}_{3}$. According to Vachtl (1969, p. 15), the kaolin resources of Bulgaria are greater than 100 million metric tons. The average kaolinite content is 18-25 percent (Grim, 1979, p. 198).

\section{CZECHOSLOVAKIA}

Kaolinized granites and arkoses are widespread in western Bohemia and southern Moravia, Czechoslovakia. Kužvart (1969a, p. 71) estimated that the country has 163 million metric tons of known kaolin reserves, 370 million metric tons of probable reserves, and more than 1 billion metric tons of "prognostic" reserves. These reserve estimates are for material containing 10-25 percent alumina (Grim, 1979, p. 199).

\section{EGYPT}

During 1966-68, the Egyptian Geological Survey, in cooperation with Soviet experts, examined most of the known clay deposits in Egypt for nonbauxite sources of aluminum (Amer and others, 1970). The largest kaolin resources known at the time of these investigations were those in the Upper Cretaceous Budra deposits in the west-central Sinai. The probable reserves in these deposits are as follows: 23.4 million metric tons containing 32-35 percent alumina and 79.0 million metric tons containing 27-32 percent alumina. The kaolin resources in the other deposits investigated were much smaller than the probable reserves in the Budra deposits.

Other kaolin deposits in Egypt that have been investigated as possible sources of alumina occur at Wadi Kalabsha, about $105 \mathrm{~km}$ southwest of Aswan (Shaaban, 1971; El Badry and others, 1981). These deposits occur as a member of the Nubia Formation. Resources were estimated by El Ramly and others $(1971$, p. 19) to be 9.4 million metric tons of pisolitic kaolin, 6.6 million metric tons of concretionary kaolin, and 0.5 million metric tons of plastic kaolin.

\section{FEDERAL REPUBLIC OF GERMANY}

Kaolin deposits occur at several places in the Federal Republic of Germany (Lippert and others, 1969). The deposits most favorable for the extraction of alumina are those in Bavaria that were investigated by the Vereinigte Aluminium-Werke A.-G. (Belsky and others, 1981). These deposits are of Tertiary age; they formed by the transportation of clay from weathered granite into the Naab Valley. The deposits are estimated to contain more than 200 million metric tons of kaolin and are present chiefly in an area $20 \times 20 \mathrm{~km}$. The calcined kaolin contains 26-32 percent $\mathrm{Al}_{2} \mathrm{O}_{3}, 55-65$ percent $\mathrm{SiO}_{2}, 2.5-5$ percent $\mathrm{Fe}_{2} \mathrm{O}_{3}, 1.0-1.5$ percent $\mathrm{TiO}_{2}, 0.2-1.5$ percent $\mathrm{CaO}$, 0.4-2.5 percent $\mathrm{MgO}$, and 1.8-2.5 percent $\mathrm{K}_{2} \mathrm{O}$.

\section{FRANCE}

About 80 percent of the kaolin production in France comes from several areas in Brittany where kaolinized granitic rocks contain 25-45 percent kaolinite (Grim, 1979, p. 199). Numerous small kaolin deposits also occur around the Massif Central (Damiani and Trautmann, 1969). Total kaolin reserves in France are greater than 100 million metric tons (Vachtl, 1969, p. 14).

\section{GERMAN DEMOCRATIC REPUBLIC}

The largest kaolin resources in the German Democratic Republic are along the north side of Mittelgeberge (Störr and others, 1969), which is in the southwestern part of the country. Kaolin extends in a belt $10-50 \mathrm{~km}$ wide. Many deposits are present as residual kaolin on weathered granite and arkose (Grim, 1979, p. 199). According to Störr and others (1969), the kaolinite content of the residual rocks in the Mittelgeberge belt ranges from 15 to 35 percent. The total kaolin resources in the country exceed 100 million metric tons (Vachtl, 1969, p. 14).

\section{GUYANA AND SURINAME}

Large kaolin deposits are closely associated with highgrade bauxite in the Coastal Plain of Guyana and in the central and eastern parts of Suriname. The sedimentary kaolin is of Late Cretaceous to early Eocene age, and the interval of bauxite formation was from early Eocene to early Oligocene. Authorities agree that the kaolin beds are the immediate parent material of the bauxite, and Kersen (1956, p. 326) has presented mineralogical evidence supporting this theory. A description of these deposits by Moses and Michell (1963) shows that the kaolin is thicker than the bauxite and underlies it. The total bauxite reserves in Guyana and Suriname are estimated at 1.275 billion metric tons (Patterson and others, 1986, table 12), and the kaolin resources associ- 
ated with the bauxite probably are at least as large as the bauxite resources. Furthermore, thick kaolin deposits have been found in the swampy areas of the Coastal Plain of central and western Suriname where bauxite is not known to be present ( $R$. Cambridge, oral commun., 1977). The kaolin resources of Guyana and Suriname probably are much greater than a billion metric tons.

\section{INDIA}

A great many occurrences of high-alumina clay in India have been described by Arogyaswamy (1968). Most of the known occurrences are small, but some are apparently large enough to be considered potential economic sources of aluminum. One such deposit in the Quilon district, Kerala, may contain a few hundred million metric tons of kaolin (Arogyaswamy, 1968, p. 79). According to Ghosh (1986), the kaolin occurs in two beds separated by sandstone, and the lower bed is purer than the upper bed. Kaolinite makes up about 25 percent of the lower bed and is derived from the underlying Precambrian crystalline rocks (Arogyaswamy, 1968, p. 79; Ghosh, 1986).

Fire clay is associated with coal beds at several places in India and may constitute large resources of alumina (Aravamuthan and Sundaram, 1965).

\section{JAMAICA}

The interest in Jamaica about nonbauxite aluminum resources has been primarily concerned with the effect these materials would have on Jamaican bauxite production. Kaolinite and halloysite occur in minor amounts in the bauxite that is mined, but both of them are abundant in the low-grade, high-silica bauxite that is not mined yet. Davis (1975), of the Ministry of Mining and Natural Resources of Jamaica, published a report on the alternatives to bauxite and concluded that demand for bauxite was likely to remain strong. A later report by Ostojic (1980), of the International Bauxite Association, lists the nonbauxite materials on a worldwide basis that would have to compete with the low-grade, high-silica bauxite from Jamaica.

\section{JAPAN}

During World War II, Japan used alunite, aluminous shale, clay, and aluminous phosphate rock for aluminum resources (table 1). The most important kaolinitic clays in Japan are sedimentary varieties called Kibushi and Gairome or Gaerome clays. Kibushi means woody material, and the name is applied to clay containing organic matter such as pieces of lignite. Gairome or Gaerome means frog eye in Japanese, and the name is given to clays containing visible quartz and other impurities
TABLE 1.-Nonbauxite aluminum resources used by Japan during World War II

[Modified from Sato and others (1956, p. 197). If ores did not contain more than 30 percent alumina, the alumina content was raised to 30 percent by beneficiation]

\begin{tabular}{|c|c|c|}
\hline Resource & Locality & $\begin{array}{c}\mathrm{Al}_{2} \mathrm{O}_{3} \text { content } \\
\text { (weight percent) }\end{array}$ \\
\hline Aluminous shale & Manchuria & $35-70$ \\
\hline Alunite ........ & Japan and Korea & $15-30$ \\
\hline Aluminous clay & Japan & $20-35$ \\
\hline Aluminous phosphate rock & $\begin{array}{l}\text { North Daitō Island, } \\
\text { Japan. }\end{array}$ & $23-30$ \\
\hline
\end{tabular}

(Hideo Minato, written commun., 1982). Kibushi clay is abundant north of Nagoya in central Japan. Both Kibushi and Gairome clays are present in the Hirono and Iwaki areas north of Tokyo. Sedimentary clays occur in the Jōban coal field in northeastern Japan, in southern Japan, and elsewhere (Fujii and others, 1976). Both flint and plastic clays are mined at the Iwate mine in northeastern Honshu, which is one of the most active refractory clay mines in Japan (Fujii and others, 1976, p. 19).

The reserves of kaolin in Japan were listed by Fujii and others (1969) as follows: Gairome clay approximately 31 million metric tons and fire clay and kaolin approximately 88 million metric tons. Sato and others (1956) listed another 59 million metric tons of clay derived from volcanic ash that may be a source of alumina (table 2). The value of kaolin in Japan as a potential alumina resource is reduced because individual deposits and districts are small and widely scattered.

TABLE 2.-Clays that are derived from Pleistocene volcanic ash and that may be a source of alumina in Japan [Modified from Sato and others (1956, p. 197)]

\begin{tabular}{|c|c|c|}
\hline Unit name & Locality & $\begin{array}{c}\text { Reserves } \\
(\text { metric tons } \\
\times 1,000)\end{array}$ \\
\hline Hayakita clay & Iburi district, Hokkaidō Prefecture... & $.5,000-6,000$ \\
\hline Fukuban soil. & $\begin{array}{l}\text { Kurosawajiri, Waga-gun, Iwate } \\
\text { Prefecture. }\end{array}$ & 28,000 \\
\hline Kanuma soil & Imaichi, Tochigi Prefecture... & 20,000 \\
\hline Joshin clay.. & Azuma-gun, Gumma Prefecture...... & 300 \\
\hline Chikushi clay & Chikushi-gun, Fukuoka Prefecture... & 10 \\
\hline Yame clay. & Yame-gun, Fukuoka Prefecture. . & 5,000 \\
\hline
\end{tabular}

\section{PAKISTAN}

High-alumina clays have been investigated at several places in Pakistan. According to Ashraf and others (1976, p. 41), resources of bauxite, clay, and aluminous laterite in Pakistan amount to 500 million metric tons. Kaolin is undoubtedly a major component of these resources. Large deposits of clay are associated with bauxite in the Kala Chitta Range and in the central part of the Salt Range, Punjab Province (Ashraf and others, 1972). The Kala Chitta deposits occur within a sedimentary forma- 
tion of Jurassic age, and the Salt Range deposits are underlain by Permian rocks and overlain by strata of Paleocene age. Other deposits associated with bauxite occur in the North-West Frontier Province and in Azad Kashmir.

Fire-clay resources in Pakistan were estimated by Gauhar (1976, p. 13) to be more than 100 million metric tons. Gauhar listed fire clay in the Sargodha, Mianwali, and Campbellpur Districts of Punjab Province, in parts of the Tatta and Dadu Districts of Sind Province, and in Dera Ismail Khan District of the North-West Frontier Province. Faruqi (1966) described high-alumina fire clay from Skesar Hills, and Raza and Iqbal (1977) listed several other fire-clay districts.

\section{PEOPLE'S REPUBLIC OF CHINA}

The eastern part of the People's Republic of China (PRC) has many high-alumina clay deposits (Zheng Zhi, written commun., 1982). However, the PRC has large resources of diaspore bauxite, and probably recovery of alumina from high-alumina clay has not been considered. The largest deposits of high-alumina clay in the PRC are of sedimentary origin. One type occurs in basins near weathered crystalline rocks from which it has been derived. A second type is clay associated with coal beds; this type is similar to underclay in the United States. Some of this Chinese underclay is more than 90 percent kaolinite. A third type is high-alumina clay or mudstone, which, in places, is several tens of meters thick, and which occurs in Paleozoic, Mesozoic, and Cenozoic strata (Ikonnikov, 1984). Many of the high-alumina clays of Paleozoic age are associated with bauxite.

A large kaolin deposit was recently discovered in Fujian Province according to Dong Bi, Geologist with the Fujian Bureau of Geology and Mineral Resources (oral commun., July 21, 1989). The size of this deposit has not been determined.

\section{SAUDI ARABIA}

According to Black (1982, p. 72), approximately 1 billion metric tons of high-alumina clay are present in the Zabirah bauxite district, Saudi Arabia. The bauxite and clay are under no more than $80 \mathrm{~m}$ of overburden in an area larger than $250 \mathrm{~km}^{2}$ (Black and others, 1984, p. 619). The clay is mainly kaolinite, but it contains some gibbsite, a trace of boehmite, and several minor impurities. The clay is in two layers, each having an average thickness of $2 \mathrm{~m}$; the average partial composition of the clay is 45 percent $\mathrm{Al}_{2} \mathrm{O}_{3}$ and 24 percent $\mathrm{SiO}_{2}$ (Black and others, 1984).

\section{SOUTH AFRICA}

The largest deposits of kaolin in South Africa are in weathered shales of Devonian to Carboniferous age
(Coetzee, 1969). These deposits were formed by weathering that took place when the Grahamstown peneplain was formed. According to Coetzee (1969, p. 62), the reserves of kaolin in deposits related to the Grahamstown peneplain are very large. Murray and Smith (1973) reported that more than 60 million metric tons of kaolinized tillite at Grahamstown, Cape of Good Hope Province, contains as much as 80 percent kaolin.

Flint clay, containing as much as 44 percent alumina after calcination, occurs in a zone from Hammanskraal to Bronkhorstspruit in the Transvaal region (Brabers, 1974). A sulfuric acid leaching process can recover $85-90$ percent of the alumina in this clay in the form of aluminum sulfate (McCulloch, 1967, p. 38-39). However, flint-clay resources are not sufficiently large to be a significant resource of alumina.

\section{SPAIN}

Many kaolin deposits are known in Spain; Galán Huertos and Espinosa de los Monteros (1974, p. 93-111) listed more than 700 kaolin claims. Of the largest of these claim areas, 3 are 5,001-8,125 ha, 8 are $1,001-5,000$ ha, 7 are 751-1,000 ha, 12 are 501-750 ha, 13 are 401-500 ha, 22 are 301-400 ha, and 38 are 201-300 ha.

According to Martín Vivaldi (1969), the most important kaolin deposits in Spain belong to two main types. One type occurs in Cretaceous sandstone in eastern Spain in Zaragoza, Teruel, Cuenca, Valencia, Castellón, and Albacete Provinces. The kaolin formed by weathering of crystalline rock and was transported to the basin in which the sandstone accumulated. The kaolinitic Cretaceous sandstone underlies large areas, is $10-20 \mathrm{~m}$ thick, and probably consists of more than 1 billion metric tons of sandstone containing 5-25 percent kaolinite (Martín Vivaldi, 1969, p. 225; Galán Huertos and Martín Vivaldi, 1973, p. 742).

The other type occurs in Galicia in northwestern Spain and consists of kaolin formed by hydrothermal alteration of deformed granites. A few of these deposits were formed by transporting the kaolin after alteration to nearby basins of deposition. The kaolin reserves in Galicia are estimated to be 300 million metric tons (Martín Vivaldi, 1969, p. 225), and the total kaolin resources in Spain are on the order of 400 million metric tons (Galán Huertos and Martín Vivaldi, 1973, p. 737).

\section{TANZANIA AND OTHER COUNTRIES IN AFRICA}

The largest kaolin resources in Tanzania consist of white kaolin-rich sandstone of Neogene age in the Pugu Hills, near Dar es Salaam (Harris, 1969). This sandstone is about $183 \mathrm{~m}$ thick, and the kaolin resources are estimated to be 2 billion metric tons.

High-alumina clay deposits occur in many other countries in Africa (Kužvart, 1969b), but insofar as is pres- 
TABLE 3.-Major aluminum-bearing materials in the United Kingdom

[Modified from Christie and Derry (1976). n.a., not available]

\begin{tabular}{|c|c|c|c|c|}
\hline Material & Location & $\begin{array}{c}\mathrm{Al}_{2} \mathrm{O}_{3} \\
\text { content } \\
\text { (weight percent) }\end{array}$ & Reserves & Comments \\
\hline Bauxite. & Northern Ireland. & $\leq 50$ & Small & Mining costs high. \\
\hline Bauxitic clay . & Scotland......... & $30-45$ & n.a.. & Reserves small. \\
\hline Ball clay & Dorset, Devon . & $\leq 45$ & n.a.. & Ceramic value high. \\
\hline China clay & Cornwall, Devon. & $\leq 40$ & n.a. & Ceramic value high. \\
\hline Nepheline syenite. & Scotland.. & $\leq 30$ & Small & \\
\hline Anorthosite ....... & Scotland, Hebrides . & $25-30$ & n.a... & Size and (or) location unfavorable. \\
\hline Schist ...... & Scottish Highlands .... & $15-25$ & Large. & Alumina content variable. \\
\hline Shale. & Wales... & $15-25$ & Inexhaustible & Alumina content low. \\
\hline Marl. . & Northwest Scottish Highlands. & $20-24$ & Large... & Alumina content low. \\
\hline Seat earth & Coal fields . . . . . . . . . . . . & $\leq 22$ & n.a............ & Mining difficult. \\
\hline Clay....... & Southern England and Scottish Highlands & $15-20$ & Inexhaustible ...... & Alumina content low. \\
\hline
\end{tabular}

ently known, few deposits are large enough to be of interest as a source of aluminum. The absence of large kaolin deposits on a large continent having enormous tropical areas is difficult to understand. The apparent absence of such deposits may be due partly to the fact that large areas have not been investigated thoroughly. Africa has large bauxite resources, and, therefore, there is little reason to explore for high-alumina clays. Tanzania is the only African country known to have large kaolin resources, and South Africa and Egypt are apparently the only African countries where kaolinitic clays have been investigated as potential sources of alumina.

\section{UNITED KINGDOM}

High-grade kaolin in the United Kingdom is found in Cornwall and Devon in the southwestern part of the country (Bristow, 1969). The kaolin occurs in granite that has been hydrothermally altered and probably later weathered. The altered granite is composed of 20-30 percent kaolinite. Reserves are very large, but meaningful tonnage estimates are not available (table 3). In addition, deposits of ball clay in southern Devon contain 90 percent kaolinite. However, these deposits are too small to have any value as an alumina resource. Ball clay occurs in three early Tertiary basins in southwestern England (Highley, 1975) - at Bovey, southern Devon, at Petrockstow, northern Devon, and in the area around Wareham, southeastern Dorset.

Enormous deposits of fire clay associated with Carboniferous coal beds are present in central and northern England and in Scotland. Much of this fire clay is 80-90 percent kaolinite, and it can be considered a potential source of alumina. High-alumina fire clays occur in the Clackmannan syncline in Scotland (Read and Dean, 1978). Fire clays containing more than 30 percent alumina occur in the Coalbrookdale, North Wales, South Derbyshire, Northumberland, Durham, West Cumbria, East Pennines, Central, and Ayshire coal fields.
In County Antrim and in parts of adjoining Londonderry County of northern Ireland, a deeply weathered zone of basalt occurs below bauxite deposits (Eyles and others, 1952). This weathered zone contains kaolinite and probably halloysite, but it is not known to contain sufficient tonnage to be considered a source of alumina.

Common clay is widely distributed in the United Kingdom (Ridgway, 1982), and the deposits have a wide range of compositions, although few exceed 20 percent alumina. The most extensive common-clay deposits are in the Carboniferous coal measures and in Jurassic sedimentary rock (Highley, 1982).

\section{U.S.S.R.}

Kaolin deposits in the U.S.S.R. number in the hundreds (Petrov, 1969), but many are small and of little importance. The most important districts are in five regions - Ukraine, Ural Mountains, Kazakhstan, Uzbekistan, and south-central Siberia.

Kaolin occurs in weathered crusts of granite in the Ukrainian Precambrian shield and has been mined in several districts. The Ukraine is the leading producer of kaolin in the U.S.S.R. The Glukhovetskoye and Prosyasovitski districts are particularly productive. The alumina content of the weathered granite is between 20 and 25 percent (Grim, 1979, p. 201).

The kaolin in the Ural Mountains also occurs in weathered granite (Grim, 1979, p. 202). The Dombarkskoie district is the most important producer.

The kaolin deposits in Kazakhstan also occur in weathered granite (V.P. Petrov and F.V. Chukrov, written commun., 1982). Those in the Alekseevskoye district, northern Kazakhstan, formed from granite and quartz diorites.

The kaolin in the Angren district, Uzbekistan, is in porphyry and tuff (V.P. Petrov and F.V. Chukrov, written commun., 1982). The Angren district is about 120 $\mathrm{km}$ southeast of Tashkent and is $12 \mathrm{~km}$ long and $4-8 \mathrm{~km}$ wide. The kaolin zone is $10-15 \mathrm{~m}$ thick. 
The kaolin deposits in south-central Siberia are in the area of the headwaters of the $\mathrm{Ob}$ and Yenisey Rivers. Kaolinitic rocks in this region are reported to be 15-20 percent alumina (Petrov, 1969; Grim, 1979, p. 201).

\section{ALUMINOUS IGNEOUS ROCKS-ANORTHOSITE}

Anorthosite is an igneous rock consisting of 90 percent or more plagioclase feldspar, $(\mathrm{Na}, \mathrm{Ca}) \mathrm{Al}(\mathrm{Al}, \mathrm{Si}) \mathrm{Si}_{2} \mathrm{O}_{8}$, which is typically andesine or labradorite but may be as calcic as bytownite or as sodic as oligoclase. Andesine contains 24-28 percent $\mathrm{Al}_{2} \mathrm{O}_{3}$ and 56-61 percent $\mathrm{SiO}_{2}$; labradorite contains 28-31 percent $\mathrm{Al}_{2} \mathrm{O}_{3}$ and 51-56 percent $\mathrm{SiO}_{2}$. The minerals other than plagioclase that are commonly present in minor amounts are clinopyroxene, orthopyroxene, potassium feldspar (commonly intergrown with plagioclase), and quartz. Accessory minerals in anorthosite include iron and titanium oxides, apatite, zircon, and sphene. Metamorphosed anorthosite intrusions contain minor amounts of biotite, hornblende, garnet, and chlorite (National Research Council, 1979, p. 143). Anorthosite occurs in large Precambrian bodies (massifs) and as segregated layers in large intrusions. Table 4 gives the chemical composition of anorthosites from three areas in the United States.
TABLE 4.-Chemical composition (in weight percent) of some U.S. anorthosites

[LOI, loss on ignition; dash (-), data not available]

\begin{tabular}{|c|c|c|c|}
\hline & 1 & 2 & 3 \\
\hline $\mathrm{SiO}_{2} \ldots \ldots \ldots \ldots \ldots \ldots$ & $51.91-55.60$ & $47.06-53.47$ & 52.9 \\
\hline $\mathrm{Al}_{2} \mathrm{O}_{3} \ldots \ldots \ldots \ldots \ldots$ & $25.87-28.92$ & $26.82-32.61$ & 27.8 \\
\hline $\mathrm{Fe}_{2} \mathrm{O}_{3} \ldots \ldots \ldots \ldots \ldots \ldots$ & $.26-1.42$ & $.03-.26$ & 1.9 \\
\hline $\mathrm{FeO} \ldots \ldots \ldots \ldots \ldots \ldots$ & $.14-2.80$ & $.37-2.60$ & - \\
\hline $\mathrm{MnO} . \ldots \ldots \ldots \ldots \ldots$ & $.00-.05$ & $.01-.04$ & - \\
\hline MgO................. & $.04-2.20$ & $.13-2.58$ & .4 \\
\hline $\mathrm{CaO} \ldots \ldots \ldots \ldots \ldots \ldots$ & $9.18-10.78$ & $11.63-16.03$ & 9,5 \\
\hline $\mathrm{Na}_{2} \mathrm{O} \ldots \ldots \ldots \ldots \ldots \ldots$ & $4.26-5.20$ & $1.97-4.65$ & 5.8 \\
\hline $\mathrm{K}_{2} \overline{\mathrm{O}} \ldots \ldots \ldots \ldots \ldots \ldots$ & $.62-1.01$ & $.06-.40$ & .3 \\
\hline $\mathrm{TiO}_{2} \ldots \ldots \ldots \ldots \ldots$ & $.08-1.29$ & $.05-.09$ & .3 \\
\hline $\mathrm{H}_{2} \mathrm{O}^{-} \ldots \ldots \ldots \ldots \ldots \ldots$ & $.01-.05$ & $.03-.07$ & - \\
\hline $\mathrm{H}_{2} \mathrm{O}^{+} \ldots \ldots \ldots \ldots \ldots \ldots$ & $.39-.94$ & $.46-1.00$ & - \\
\hline $\mathrm{CO}_{2} \ldots \ldots \ldots \ldots \ldots \ldots$ & $.02-.82$ & $.00-.01$ & - \\
\hline LOI $\ldots \ldots \ldots \ldots \ldots \ldots$ & - & - & .7 \\
\hline $\mathrm{P}_{2} \mathrm{O}_{5} \ldots \ldots \ldots \ldots \ldots \ldots$ & $.04-.11$ & $.01-.05$ & - \\
\hline S............. & $.00-.04$ & - & - \\
\hline $\mathrm{BaO} \ldots \ldots \ldots \ldots \ldots \ldots$ & $.03-.06$ & - & - \\
\hline
\end{tabular}

1. Range in composition of samples from the Laramie Mountains, Wyo. (Hagner, 1951, table 1 , samples 1-5).

2. Range in composition of samples from Boehls Butte, Idaho (Hietanen, 1963, table 11 samples $949,1016,1015,611$ ).

3. Sample from the San Gabriel Mountains, Calif. (Lundquist, 1963, table 1).

TABLE 5.-Major anorthosite bodies in the United States

[Modified from National Research Council (1979, table 5.9). Dash (-), data not available. Do., ditto]

\begin{tabular}{|c|c|c|c|c|c|c|c|}
\hline $\begin{array}{l}\text { Locality } \\
\text { number } \\
\text { in } \\
\text { figure } 2\end{array}$ & Anorthosite body & County & State & $\begin{array}{l}\text { Area } \\
\left(\mathrm{km}^{2}\right)\end{array}$ & $\begin{array}{c}\text { Minimum } \\
\text { tonnage } \\
\text { (metric } \\
\text { tons } \\
\times 10^{9} \text { ) }\end{array}$ & $\begin{array}{c}\mathrm{Al}_{2} \mathrm{O}_{3} \\
\text { content } \\
\text { (weight } \\
\text { percent) }\end{array}$ & References \\
\hline 1 & San Gabriel Mountains.. & Los Angeles. . & California..... & 135 & 27 & 27 & $\begin{array}{l}\text { Oakeshott in Lundquist, 1963; } \\
\text { Carter and Silver, 1972; } \\
\text { Ryder and others, 1975. }\end{array}$ \\
\hline 2 & Piedmont. & New Castle & Delaware..... & - & - & - & Thompson, 1975. \\
\hline 3 & Boehls Butte.. & Shoshone, Clearwater.... & Idaho ......... & 150 & 2.6 & 29 & Hietanen, 1963. \\
\hline 4 & Keweenawan series..... & Cook, Lake ............ & Minnesota .... & 520 & .9 & 30 & Phinney, 1968; Green, 1972. \\
\hline 5 & Duluth Complex........ & Lake ................. & Minnesota .... & - & - & - & $\begin{array}{l}\text { Taylor, 1964; Davidson, 1972; } \\
\text { Phinney, 1968, 1969, 1972a,b. }\end{array}$ \\
\hline 6 & Stillwater Complex. & Stillwater, Sweet Grass . & Montana. . & 18 & 3.7 & 30 & Bowes and others, 1973. \\
\hline 7 & $\begin{array}{l}\text { Bitterroot Range....... } \\
\text { Adirondacks: }\end{array}$ & Ravalli...... & Montana...... & 2.5 & - & - & Berg, 1968. \\
\hline 8 & $\begin{array}{l}\text { Main body (Marcy } \\
\text { massif). }\end{array}$ & Essex, Franklin & New York.... & 3,300 & 342 & 26 & $\begin{array}{l}\text { Buddington, 1968, 1972; } \\
\text { Isachsen and Moxham, 1968; } \\
\text { Letteney, } 1968 .\end{array}$ \\
\hline 9 & Thirteenth Lake & Hamilton, Warren & New York.... & 235 & 10 & 26 & Do, \\
\hline 10 & Carthage ........... & Jefferson.......... & New York.... & 2 & .45 & 26 & Do. \\
\hline 11 & Rand Hill........ & Clinton ......... & New York.... & 15 & 2.6 & 25 & Do. \\
\hline 12 & Wichita Mountains ... & $\begin{array}{l}\text { Kiowa, Comanche, } \\
\text { Jackson. }\end{array}$ & Oklahoma .... & 40 & .9 & 28 & Scofield, 1975 . \\
\hline 13 & Honey Brook & Chester... & Pennsylvania & 40 & .18 & 27 & Crawford and others, 1971. \\
\hline 14 & Roseland .. & Nelson, Amherst. . & Virginia ...... & $<60$ & - & 24 & $\begin{array}{l}\text { Herz, 1968; Herz and Force, } \\
1984 .\end{array}$ \\
\hline 15 & Mineral Lake & Ashland. & Wisconsin & 120 & - & - & Olmsted, 1968. \\
\hline 16 & Laramie Range & Albany, Laramie. . & Wyoming..... & 518 & 32.8 & $25-30$ & $\begin{array}{l}\text { St. Clair and others, 1959; } \\
\text { Hagner, 1951; Newhouse and } \\
\text { Hagner, 1957; De Vore, } 1975 .\end{array}$ \\
\hline
\end{tabular}




\section{UNITED STATES}

Anorthosite bodies are widely scattered through the United States (table 5, fig. 2). The deposits that have been investigated most thoroughly as potential sources of alumina are the large bodies in the Laramie Range, Wyo., and in the San Gabriel Mountains, Calif. The anorthosite bodies in the Laramie Range underlie more than $518 \mathrm{~km}^{2}$ according to maps by Hagner (1951, fig. 1) and Newhouse and Hagner (1957). The total resources of anorthosite in these bodies that are less than $30 \mathrm{~m}$ below the average ground level are estimated to be 30.2 billion metric tons (St. Clair and others, 1959, p. 69). The total anorthosite present is many times this figure because the rock extends to depths of more than $228 \mathrm{~m}$. Most of this rock contains $25-30$ percent alumina, and it is also rich in calcium and sodium (table 4).
Anorthosite in the central part of the western San Gabriel Mountains, Calif., crops out or is near the surface in an area of $135 \mathrm{~km}^{2}$ (Oakeshott in Lundquist, 1963, p. 9); exposures are at altitudes ranging from 520 to 1,980 $\mathrm{m}$. Reserves are very large. The average alumina content of eight samples analyzed is 27.16 percent.

\section{CANADA}

Anorthosite is Canada's most abundant potential source of alumina, and the Canadian Centre for Mineral and Energy Technology (CANMET) has done considerable research on the extraction of alumina from anorthosite (Quon, 1976; Ripley, 1976; Hamer and others, 1978; Winer and Quon, 1979). Many of the anorthosite bodies in Canada have alumina contents of 24-28 percent (Hamer and others, 1978, p. 97), and parts of some bodies con-

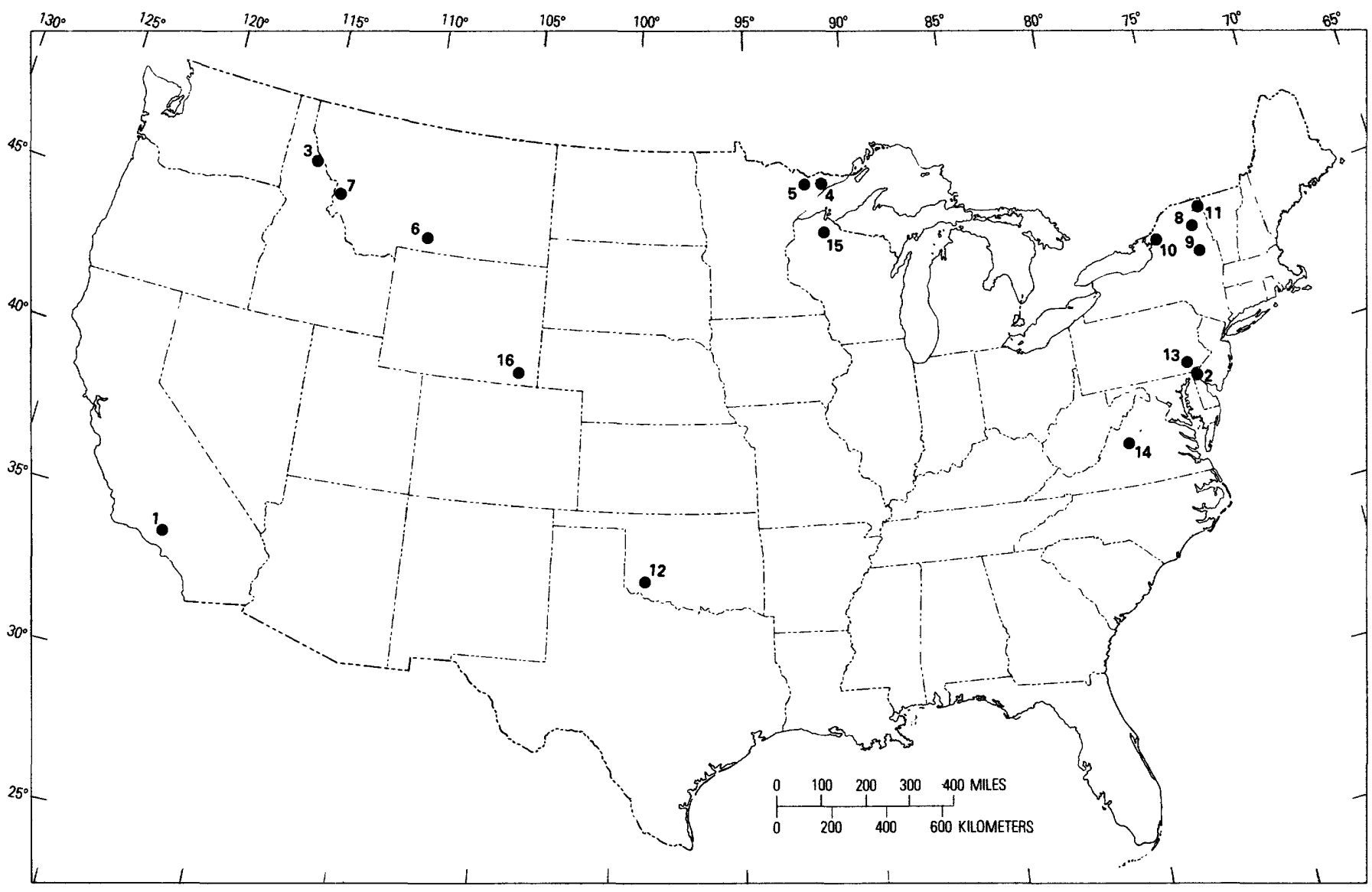

EXPLANATION
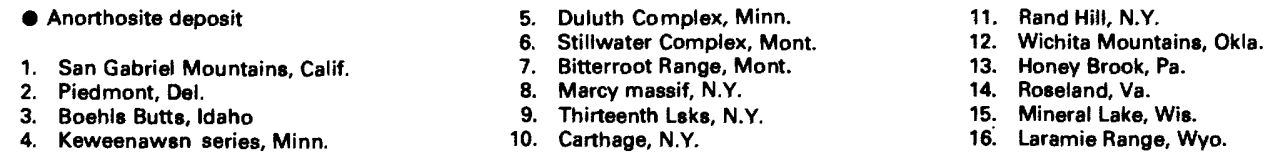

FIGURE 2. - Major anorthosite deposits in the United States. Modified from National Research Council (1979, fig. 5.14). Deposit sizes are provided in table 5 . 
tain as much as 30 percent alumina (table 6). Although only general geologic reconnaissance investigations have been completed in several large areas, the anorthosite bodies are known to underlie thousands of square kilometers. A report compiled by Anderson (1968) contains a table of the world anorthosite resources that gives estimates of the area covered by each anorthosite mass known at the time the work was done. At the time Anderson compiled his report, 55 anorthosite bodies were known in Canada. Most of these bodies are in Quebec and Labrador. Sixteen of these bodies underlie areas ranging from about $1,000 \mathrm{~km}^{2}$ to $20,000 \mathrm{~km}^{2}$. The total area underlain by the 16 bodies is about $80,000 \mathrm{~km}^{2}$. The known anorthosite resources of Canada are far greater than those of any other country. The aluminum in anorthosite bodies of Canada could supply the world's requirements for aluminum for many centuries if an alumina extraction process were to become feasible.

\section{FINLAND}

Shaikh (1977, p. 194) listed six bodies of anorthosite in Finland. The largest body is at Vaskojoki, which is west of Lake Inari in the northern part of Finland. The Vaskojoki anorthosite contains as much as 30 percent alumina. Other bodies of anorthosite occur at Repokaise, Nitsijärvi, Mustavaara, Otanmäki, and Avenisto.

\section{GREENLAND}

According to many authors (Windley, 1969; Walton, 1973; Upton, 1974; Bondam, 1976), anorthosite gabbros in the Fiskenaesset area of southwestern Greenland are potential nonbauxite sources of aluminum because they contain approximately 30 percent alumina and are very low in iron oxides. The anorthosite bodies are at the coast and, therefore, are readily accessible to ocean transport.

\section{NORWAY}

Shaikh (1977, p. 194) stated that " $[t]$ here are a number of anorthosite intrusions in Norway," but he provided information on only two. He reported the alumina contents of the anorthosites at Indre Sogn and Egersund as 28-30 percent and 24-26 percent, respectively, and he estimated that the two areas contained several billion metric tons of anorthosite. Anderson (1968, table 1) listed four anorthosite districts in Norway-the Egersund district, which he reported as having an area of 900 $\mathrm{km}^{2}$, the Vossestrand district, which has an area of 100 $\mathrm{km}^{2}$, and the Jotun and Lofoten districts, for which no sizes were available.

\section{SOUTH KOREA}

The South Korean Research Institute of Geoscience and Mineral Resources discovered a large anorthosite
TABLE 6.-Nonbauxite sources of alumina in Canada [From Winer (1977, table 1)]

\begin{tabular}{|c|c|c|c|}
\hline Material & $\begin{array}{l}\text { Aluminiferous } \\
\text { component }\end{array}$ & $\begin{array}{c}\mathrm{Al}_{2} \mathrm{O}_{3} \\
\text { content } \\
\text { (weight } \\
\text { percent) }\end{array}$ & Location \\
\hline Anorthosite .... & Plagioclase ..... & $24-30$ & $\begin{array}{l}\text { Quebec and southern } \\
\text { Ontario. }\end{array}$ \\
\hline $\begin{array}{l}\text { Nepheline } \\
\text { syenite. }\end{array}$ & Nepheline...... & $21-28$ & Ontario and Quebec. \\
\hline Clay...... & Kaolinite....... & $\begin{array}{l}20-22 \\
20-24 \\
10-16 \\
20-24\end{array}$ & $\begin{array}{l}\text { Nova Scotia. } \\
\text { Quebec. } \\
\text { Northern Ontario. } \\
\text { Southern } \\
\quad \text { Saskatchewan. }\end{array}$ \\
\hline Shale... & $\begin{array}{l}\text { Feldspar and } \\
\text { mixed clays. }\end{array}$ & $\begin{array}{c}20-25 \\
20 \\
24 \\
20\end{array}$ & $\begin{array}{l}\text { British Columbia. } \\
\text { Newfoundland. } \\
\text { Nova Scotia. } \\
\text { New Brunswick. }\end{array}$ \\
\hline $\begin{array}{l}\text { Coal shale and } \\
\text { coal-washing } \\
\text { rejects. }\end{array}$ & $\begin{array}{l}\text { Kaolinite and } \\
\text { feldspar. }\end{array}$ & $\begin{array}{l}\leq 29 \\
\leq 22 \\
\leq 36\end{array}$ & $\begin{array}{l}\text { Nova Scotia. } \\
\text { Saskatchewan. } \\
\text { Alberta and British } \\
\text { Columbia. }\end{array}$ \\
\hline Fly ash....... & $\begin{array}{l}\text { Mullite and } \\
\text { glass. }\end{array}$ & $\leq 30$ & British Columbia. \\
\hline
\end{tabular}

stock near Hadong in the southern part of South Korea. The discovery was erroneously reported in some trade journals as the finding of a billion metric tons of bauxite; Professor Byung Koo Hyun (written commun., July 20, 1976) informed us that it is definitely anorthosite. The institute investigated this anorthosite as a possible source of alumina.

Anderson (1968, table 1) listed only the Chingyo anorthosite deposit in southern South Korea. According to the geologic map by Kim and Kang (1965), the Chingyo deposit underlies about $32 \mathrm{~km}^{2}$ west of Hadong and east of Chinjoo. This is probably the same deposit mentioned by Professor Byung Koo Hyun. The anorthosite is composed mainly of anhedral andesine and labradorite and contains some hornblende (Kim and Kang, 1965, p. 7 of the English version).

\section{SWEDEN}

Anorthosite occurs at several places in Sweden (Shaikh, 1977, p. 194). The largest body is in the Ruotevare district, northwest of Kvikkjokk, where the intrusion underlies $70-100 \mathrm{~km}^{2}$. Iron deposits associated with the anorthosite contain 47 percent $\mathrm{Fe}_{2} \mathrm{O}_{3}, 11$ percent $\mathrm{TiO}_{2}$, and 0.26 percent $\mathrm{V}_{2} \mathrm{O}_{5}$. The second largest anorthosite body in Sweden underlies an area of $33 \mathrm{~km}^{2}$ at Nordingrå (Shaikh, 1977, p. 194). Three anorthosite masses occur northeast of Stockholm, and at least five small anorthosite bodies are known elsewhere in Sweden. 


\section{U.S.S.R.}

Much of the early work on anorthosite in the U.S.S.R. was cited by Anderson (1968) and was used in his compilation. A more recent volume on the subject is that edited by Bogatikov (1974). In this volume, Bogatikov and A.P. Birkis (p. 5-20) recognized seven widely distributed anorthosite regions in the U.S.S.R. - (1) Kola Peninsula, (2) Baltic region, (3) Ukraine, (4) VolgaUrals, (5) Anabar, (6) Aldan, and (7) Okhotsk.

Kola Peninsula region.-Gabbros and anorthosite rocks are widely distributed on the Kola Peninsula. These rocks occur on the Glavnyi (main) ridge and in intrusive rocks of the Keivy region and Sal'nyi, Kandalaksha, and Kolvitsa tundras (Bogatikov and Birkis in Bogatikov, 1974, p. 6; B.A. Yudin in Bogatikov, 1974, p. 21-29; E.V. Sharkov in Bogatikov, 1974, p. 30-41). The Glavnyi ridge massifs underlie an area of $1,000 \mathrm{~km}^{2}$ along the contact between metamorphosed Precambrian rocks and pyroxene schist.

Baltic region. - Numerous gabbro-norite-anorthosite massifs are associated with a large granitic pluton in western Latvia (Birkis and Bogatikov in Bogatikov, 1974 , p. 42-47). The total area underlain by anorthosite is more than 2,700 km ${ }^{2}$ (Bogatikov and Birkis in Bogatikov, 1974, p. 7).

Ukraine region.-More than 10 gabbro-noriteanorthosite massifs in the Ukraine underlie a total area of about $4,000 \mathrm{~km}^{2}$ (Bogatikov and Birkis in Bogatikov, 1974 , p. 7). These rocks were investigated by several Soviet geologists (V.N. Moshkin and I.N. Dagelaiskaya in Bogatikov, 1974, p. 48-56), who have shown that all anorthosite massifs are within two large plutons of granite and related igneous rocks that are younger than the anorthosite. These plutons were emplaced in the Archean-Early Proterozoic basement.

Volga-Urals region. - Three large anorthosite bodies, underlying a total area of $1,000 \mathrm{~km}^{2}$, have been found in the Volga-Urals region (S.V. Bogdanova in Bogatikov, 1974 , p. 57-69).

Anabar region. - The Anabar anorthosite occurs as batholithic massifs in the central Siberia Precambrian shield area north of the Arctic Circle. B.G. Lutts (in Bogatikov, 1974, p. 70-84) reported the following anorthosite massifs: (1) one in the central part of the region underlying $765 \mathrm{~km}^{2}$; (2) one in the northern part of the region underlying $180 \mathrm{~km}^{2}$; (3) one in the eastern part of the region underlying $100 \mathrm{~km}^{2}$; and (4) two in the southern part of the region, one underlying $14 \mathrm{~km}^{2}$, and the other, $8 \mathrm{~km}^{2}$.

Aldan region. - More than one anorthosite body is present in the Aldan region, but the Kalar massif has received the most attention (Bogatikov and Birkis in Bogatikov, 1974, p. 5-20; G.N. Bazhenova in Bogatikov,
1974, p. 85-99). The Kalar massif extends along the eastern margin of Early Proterozoic rocks in a northeasterly direction for as much as $150 \mathrm{~km}$. It ranges in width from 5 to $20 \mathrm{~km}$. The total area underlain by anorthosite is about $1,500 \mathrm{~km}^{2}$ (Bazhenova in Bogatikov, 1974, p. 86).

Okhotsk region.-The region in eastern Siberia extending west from the Okhotsk Sea, called the Okhotsk region by Bogatikov and Birkis (in Bogatikov, 1974 , p. 5-20), contains several anorthosite bodies of Precambrian age. Included are the very large Dzhugdzhur and the smaller Lavlin and Sekhtag anorthosite massifs. The host rocks are schists and gneisses that were metamorphosed to the granulite facies and somewhat younger igneous rocks including charnockites, syenites, and rapakivi granites (A.M. Lennikov in Bogatikov, 1974, p. 100-112).

\section{OTHER COUNTRIES}

In addition to the countries mentioned above, anorthosite occurs in 15 localities in India, 4 localities each in Tanzania and Madagascar, 3 localities in the People's Republic of China, 2 localities in Australia, and 1 locality each in the United Kingdom, Angola, Egypt, Mozambique, Antarctica, and Brazil (Anderson, 1968, table 1). Anorthosite also occurs in the Bushveld Complex and elsewhere in South Africa. The Bushveld Complex has been studied as a potential source of aluminum (Brabers, 1974).

\section{ALUMINOUS IGNEOUS ROCKS-NEPHELINE SYENITE AND PHONOLITE}

Coarsely crystalline nepheline syenite and its finegrained equivalent, phonolite, are igneous rocks composed chiefly of feldspar and nepheline. Nepheline, $(\mathrm{Na}, \mathrm{K}) \mathrm{AlSiO}_{4}$, is a feldspathoid mineral consisting of 21.8 percent $\mathrm{Na}_{2} \mathrm{O}, 35.9$ percent $\mathrm{Al}_{2} \mathrm{O}_{3}$, and 42.3 percent $\mathrm{SiO}_{2}$. Nepheline syenite bodies are more variable in composition than anorthosite, but generally feldspar and nepheline make up 80-90 percent of the rock. The remainder is primarily alkalic pyroxene and as much as 5 percent accessory minerals (table 7). Nepheline contents range from a trace to 40 percent. In some syenites, other feldspathoids such as analcime or sodalite substitute for nepheline.

Aluminous rock types related to nepheline syenite are urtite, which contains more than 70 percent nepheline and 0-29 percent mafic minerals, and ijolite, which contains 40-70 percent nepheline and 30-60 percent mafic minerals. Nepheline syenite and phonolite are deficient in silicon, calcium, magnesium, and iron, and they are enriched in aluminum (table 8). Because of the silica deficiency, alumina can be recovered from 
TABLE 7.-Mineral composition of nepheline syenite [Modified from National Research Council (1979, table 5.13)]

\begin{tabular}{|c|c|c|}
\hline Mineral & Formula & $\begin{array}{c}\text { Concen- } \\
\text { tration } \\
\text { range } \\
\text { (weight } \\
\text { percent) }\end{array}$ \\
\hline \multicolumn{3}{|l|}{ Principal minerals: } \\
\hline Nepheline...... & $\mathrm{Na}_{3} \mathrm{~K}\left[\mathrm{Al}_{4} \mathrm{Si}_{4} \mathrm{O}_{16}\right]$ & $0-40$ \\
\hline Alkalic feldspar..... & $(\mathrm{K}, \mathrm{Na})\left[\mathrm{AlSi}_{3} \mathrm{O}_{8}\right]$ & $0-50$ \\
\hline Alkalic pyroxene.... & $(\mathrm{Na}, \mathrm{Ca})\left(\mathrm{Fe}^{+3}, \mathrm{Fe}^{+2}, \mathrm{Mg}, \mathrm{Al}\right)\left[\mathrm{Si}_{2} \mathrm{O}_{6}\right]$ & $5-10$ \\
\hline Analcime........... & $\mathrm{NaAlSi}_{2} \mathrm{O}_{6} \cdot \mathrm{H}_{2} \mathrm{O} \ldots \ldots \ldots \ldots \ldots \ldots$ & $0-10$ \\
\hline Sodalite. . & $\mathrm{Na}_{8}\left[\mathrm{Al}_{6} \mathrm{Si}_{6} \mathrm{O}_{24}\right] \mathrm{Cl}_{2}$ & $0-5$ \\
\hline \multicolumn{3}{|l|}{ Accessory minerals: } \\
\hline Melilite........... & $\begin{array}{l}(\mathrm{Ca}, \mathrm{Na}, \mathrm{K})_{2} \\
\quad\left[\left(\mathrm{Mg}, \mathrm{Fe}^{+2}, \mathrm{Fe}^{+3}, \mathrm{Al}, \mathrm{Si}\right)_{2} \mathrm{O}_{7}\right]\end{array}$ & $0-5$ \\
\hline Sphene & $\mathrm{CaTi}\left[\mathrm{SiO}_{4}\right](\mathrm{O}, \mathrm{OH}, \mathrm{F}) \ldots \ldots \ldots$ & $0-5$ \\
\hline Apatite. & $\mathrm{Ca}_{5}\left(\mathrm{PO}_{4}\right)_{3}(\mathrm{OH}, \mathrm{F}, \mathrm{Cl})$ & $0-2$ \\
\hline Zircon. & $\mathrm{ZrSiO}_{4} \ldots \ldots \ldots \ldots$ & $0-2$ \\
\hline Pyrochlore . & $\left.(\mathrm{Na}, \mathrm{Ca})_{2}(\mathrm{Nb}, \mathrm{Ti})_{2} \mathrm{O}_{6} \mathrm{OH}, \mathrm{F}\right)$ & $0-$ ? \\
\hline Rutile & $\mathrm{TiO}_{2} \ldots \ldots$ & $0-?$ \\
\hline Magnetite.. & $\mathrm{Fe}_{3} \mathrm{O}_{4}$ & $0-1$ \\
\hline Perovskite... & $\left(\mathrm{Ca}, \mathrm{Na}, \mathrm{Fe}^{+2}, \mathrm{Ce}\right)(\mathrm{Ti}, \mathrm{Nb}) \mathrm{O}_{3}$ & $?$ \\
\hline Eudialyte... & $\mathrm{Na}_{4}\left(\mathrm{Ca}, \mathrm{Fe}^{+2}\right)_{2} \mathrm{ZrSi}_{6} \mathrm{O}_{7}(\mathrm{OH}, \mathrm{Cl})_{2} \ldots$ & ? \\
\hline \multicolumn{3}{|l|}{ Columbite- } \\
\hline tantalite & $(\mathrm{Fe}, \mathrm{Mn})(\mathrm{Ta}, \mathrm{Nb})_{2} \mathrm{O}_{6}$ & ? \\
\hline
\end{tabular}

feldspathoid-bearing rocks more readily than from other igneous rocks that are either low in alumina or high in silica, or both.

The U.S.S.R. was the first country to utilize nepheline syenite commercially for the production of aluminum. After World War II, the U.S.S.R. produced alumina and alkalies and cement from waste nepheline concentrates from the Kola apatite mines (Allen and Charsley, 1968, p. 98). Deposits of nepheline syenite in Egypt and in other countries have been investigated as a potential source of aluminum. Nepheline syenite is used in the manufacture of glass and ceramics in Canada and Norway and for roofing granules and crushed rock in the United States and in other countries (Allen and Charsley, 1968, p. 1). Phonolite was investigated as a source of alumina in Germany in 1939 (U.S. Bureau of Mines, 1939, p. 2), and phonolite is mined in the Federal Republic of Germany and Czechoslovakia for use in the manufacture of glass and ceramics (Allen and Charsley, 1968, p. 2).

\section{UNITED STATES}

Nepheline syenite bodies are widely distributed in the United States (fig. 3, table 9), and phonolite is present in several areas. Barker (1974, table 1) listed the occurrences of North American alkalic rocks, which include nepheline syenite and phonolite. Clearly, the United States would have ample resources if alumina could be recovered profitably from nepheline syenite. However, there have been no serious attempts in the United States to recover alumina from this rock. The alumina contents of U.S. nepheline syenite and anorthosite are 17-23 percent and 25-33 percent, respectively, and the silica contents of both rock types are approximately equal (tables 4, 9). U.S. anorthosite resources are very large. Therefore, aluminum recovery from nepheline syenite is unlikely in the United States.

\section{CANADA}

Hewitt (1957, p. 186) noted the following historical facts regarding interest in Canadian nepheline syenite as a possible source of alumina, "The earliest commercial interest in Ontario nepheline syenite began in 1912 when N.B. Davis sampled a nepheline deposit on Exolon Hill as a potential source of alumina." During World War II, the Aluminium Company of Canada (Alcan) and Ventures Limited became interested in nepheline syenite as a potential source of alumina, and considerable diamond drilling was undertaken in the Bancroft area (fig. 4).

For many years after 1936, Canada was the sole producer of nepheline syenite for the glass and ceramics industries. All but a small proportion of the production came from the Blue Mountain district (Allen and Charsley, 1968, p. 64) in Ontario about $151 \mathrm{~km}$ northeast of Toronto (fig. 4). Blue Mountain consists of a group of glaciated ridges that stand $61-107 \mathrm{~m}$ above the surround-

TABLE 8.-Chemical composition (in weight percent) of nepheline syenite from Canada, Norway, and Scotland [LOI, loss on ignition; dash (-), data not available]

\begin{tabular}{|c|c|c|c|c|c|}
\hline & \multirow{2}{*}{$\begin{array}{c}\text { Canada } \\
1\end{array}$} & \multicolumn{2}{|c|}{ Norway } & \multicolumn{2}{|c|}{ Scotland } \\
\hline & & 2 & 3 & 4 & 5 \\
\hline $\mathrm{SiO}_{2} \ldots \ldots \ldots$ & 59.18 & 52.37 & 52.73 & 55.1 & 51.2 \\
\hline $\mathrm{Al}_{2} \mathrm{O}_{3} \ldots \ldots$ & 23.06 & 23.22 & 23.71 & 22.7 & 22.9 \\
\hline $\mathrm{Fe}_{2} \mathrm{O}_{3} \ldots \ldots$ & 2.15 & 1.14 & 1.89 & 2.2 & 3.1 \\
\hline $\mathrm{FeO} \ldots \ldots \ldots$ & - & 1.86 & 1.04 & - & - \\
\hline $\mathrm{MnO} \ldots \ldots \ldots$ & - & .09 & .06 & - & - \\
\hline $\mathrm{MgO} \ldots \ldots \ldots$ & .17 & .25 & .24 & .4 & .3 \\
\hline $\mathrm{CaO} \ldots \ldots \ldots$ & .76 & 3.11 & 2.54 & 1.9 & 3.3 \\
\hline $\mathrm{Na}_{2} \mathrm{O} \ldots \ldots$ & 10.48 & 6.87 & 7.78 & 2.2 & 5.2 \\
\hline $\mathrm{K}_{2} \mathrm{O} \ldots \ldots \ldots$ & 3.94 & 8.30 & 8.08 & 12.8 & 8.8 \\
\hline $\mathrm{TiO}_{2} \ldots \ldots \ldots$ & .06 & .61 & .51 & - & - \\
\hline $\mathrm{H}_{2} \mathrm{O}^{-} \ldots \ldots \ldots$ & - & .04 & .05 & - & 一 \\
\hline $\mathrm{H}_{2} \mathrm{O}^{+} \ldots \ldots \ldots$ & - & .26 & .26 & - & - \\
\hline $\mathrm{CO}_{2} \ldots \ldots \ldots$ & - & 1.88 & .77 & - & - \\
\hline LOI. . . . . . . . & .4 & 一 & - & - & - \\
\hline $\mathrm{P}_{2} \mathrm{O}_{5} \ldots \ldots \ldots$ & .02 & .09 & .05 & - & - \\
\hline $\mathrm{Cl} \ldots \ldots \ldots$ & - & - & 一 & - & - \\
\hline $\mathrm{BaO} \ldots \ldots \ldots$ & - & .34 & .32 & - & - \\
\hline SrO . . . . . . . & - & .59 & .39 & - & - \\
\hline $\mathrm{ZrO}_{2} \ldots \ldots$ & .05 & - & - & 一 & 一 \\
\hline Total....... & 100.27 & 101.02 & 100.42 & 97.3 & 94.8 \\
\hline
\end{tabular}

1. Nepheline syenite from Blue Mountain, Ontario, Canada. From Derry and Phipps (1957, table 1) and Allen and Charsley (1968, p. 68).

2. Biotite nepheline syenite from Stjernöy, Norway. From Heier (1966, table 1) and Allen and Charsley (1968, p. 90).

3. Pyroxene-sphene nepheline syenite from Stjernöy, Norway. From same seurces as data in column 2.

4. Gray nepheline syenite from the Loch Borolan complex, Loynes Valley, Seotland. Average of 13 samples. From Allen and Charsley (1968, p. 46).

5. Gray nepheline syenite from the Loch Borolan complex, Aultivullin, Scotland. Average of nine samples. From Allen and Charsley (1968, p. 46). 
ing peneplain. The main mass of nepheline syenite exposed in Blue Mountain crops out in an area about 4.0 $\mathrm{km}$ long and $2.0 \mathrm{~km}$ wide (Hewitt, 1961).

Many Rosiwal modal analyses (Keith, 1939, p. 1806) show that the Blue Mountain nepheline syenite has the following representative mineralogical composition: 54 volume percent albite, 20 percent microcline, 22 percent nepheline, 2 percent muscovite, and 2 percent mafic minerals. The chemical composition of typical Blue Mountain nepheline syenite is given in table 8.

Nepheline syenite bodies also occur at numerous other places in Ontario, including Monteagle and elsewhere in the Haliburton-Bancroft area (Adams and Barlow, 1910; Moyd, 1949), Sioux Lookout (Allen and Charsley, 1968, p. 75), and the following eight districts discussed by Hewitt (1957): (1) Sturgeon Lake, (2) Port Coldwell, (3) Herman Lake, (4) Nemegosenda Lake, (5) Nemegos, (6) Otto, (7) French River, and (8) Callander Bay (fig. 4).

Nepheline syenite occurs in the following localities in Quebec: (1) Lake Albanel district (Neilson, 1953); (2) Gouin Reservoir basin (Laurin, 1965); (3) LabelleL'Annonciation area (Osborne, 1935); (4) Oka and Mount Royal area or Monteregian Hills, Montreal (Finley, 1930); and (5) St. Hilaire area (O'Neill, 1914).

In addition to the deposits in Ontario and Quebec, nepheline syenite occurs at scattered localities in British Columbia (Allen and Charsley, 1968, p. 75).

\section{EGYPT}

Thorough investigations of nepheline syenite in Egypt were conducted from 1966 to 1969 by the Egyptian Geological Survey with the cooperation of Soviet geologists and aluminum experts (El Ramly, Dereniuk, and others, 1970). The main nepheline syenite deposit investigated was in the Jabal Abū Khurūq (spelled Gabal Abu Khruq in some reports) massif about $140 \mathrm{~km}$ northeast of the Aswan Dam. This massif is an oval complex consisting of an incomplete ring of alkalic syenite intrusive bodies surrounding a group of conical or stocklike intrusive bodies of nepheline syenite. The part of the massif on which most of the field work was done contains 26 million metric tons of nepheline syenite in which the average content of the main components is 55.69 percent $\mathrm{SiO}_{2}, 21.08$ percent $\mathrm{Al}_{2} \mathrm{O}_{3}, 4.92$ percent $\mathrm{Fe}_{2} \mathrm{O}_{3}, 9.63$ percent $\mathrm{Na}_{2} \mathrm{O}$, and 5.08 percent $\mathrm{K}_{2} \mathrm{O}$ (El Ramly, Dereniuk, and others, 1970, p. 178-179). Another part of the massif that was less thoroughly investigated was estimated to contain an additional 40 million-50 million metric tons of rock of similar composition.

A large sample of the nepheline syenite was studied in U.S.S.R by the All Union Institute of Aluminum and Magnesium (VAMI) in Leningrad. The VAMI metallur- gical tests and similar tests by the Egyptian Geological Survey showed that alumina can be recovered from the Jabal Abū Khurūq nepheline syenite when it is mixed with Egyptian limestone. The VAMI process yields valuable byproducts. An annual production of 100,000 metric tons of alumina would yield the following byproducts: 1.5 million-1.6 million metric tons of portland cement, 75,000 metric tons of soda, and 30,000-35,000 metric tons of potash (El Ramly, Dereniuk, and others, 1970, p. 180).

The investigation also showed the presence of at least nine other igneous ring complexes between the Nile River and the Red Sea (El Ramly, Budanov, and others, 1970). At least four of these complexes contain nepheline syenite.

\section{MEXICO}

Nepheline syenite occurs near the town of San José about $64 \mathrm{~km}$ southeast of Linares in northeastern Mexico (Allen and Charsley, 1968, p. 130). It extends for $24 \mathrm{~km}$ south of the town of San José and forms part of the San Carlos Mountains. The Arroya Grande nepheline syenite, which is the most commercially interesting of the three types present in this area, contains, by volume, 60 percent orthoclase, 25 percent nepheline, 5 percent plagioclase, 1 percent augite, 8 percent magnetite, and 0.7 percent sphene. This nepheline syenite is probably the material that Industria Penoles SA planned to process for alumina when it acquired the U.S.S.R.'s VAMI process (Industrial Minerals, 1979a).

\section{NORWAY}

Norway is surpassed only by Canada and the U.S.S.R. in the production of nepheline syenite, which has all been obtained from one mine on the island of Stjernöy (fig. 5), $402 \mathrm{~km}$ north of the Arctic Circle (Allen and Charsley, 1968, p. 88). This deposit is thought to be a stocklike body having a lenticular outcrop $1,829 \mathrm{~m}$ long and about $244 \mathrm{~m}$ wide. Mining is by underground methods, and so the mine can be worked the entire year. Production began in 1961. Two grades of beneficiated nepheline syenite are produced, one for making glass and one for making ceramics.

Two types of nepheline syenite are recognized at Stjernöy (Heier, 1966; Allen and Charsley, 1968). Pyroxene-sphene nepheline syenite is more abundant and occupies the center of the outcrop. Biotite nepheline syenite is present primarily at the ends of the body. The chemical compositions are listed in table 8.

Allen and Charsley $(1968, p .88)$ noted the presence of several other nepheline syenite bodies in Norway. 


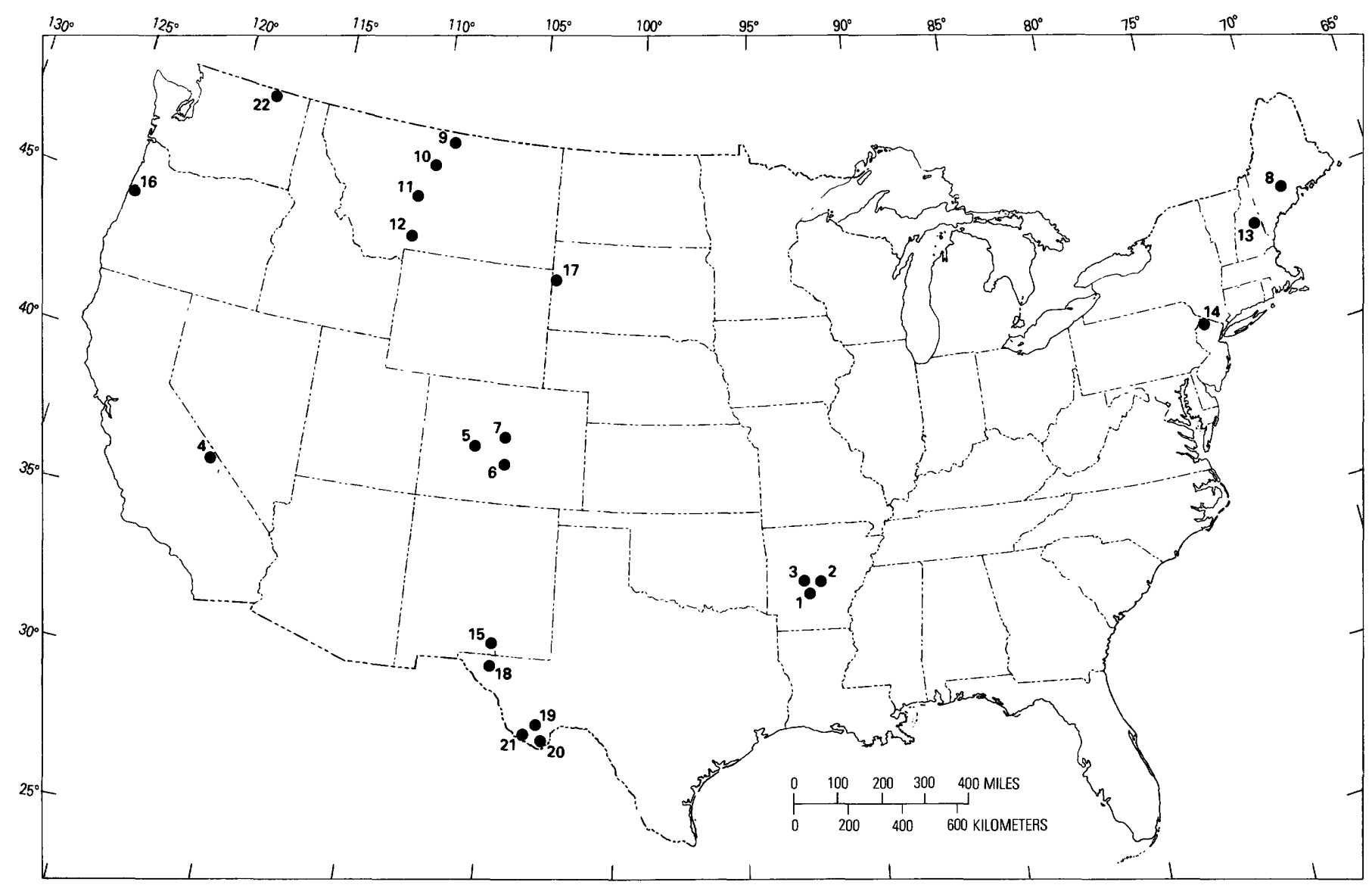

EXPLANATION

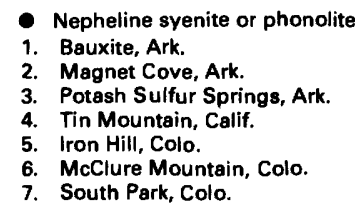

8. Litchfield, Maine 9. Bearpaw Mountains, Mont. 10. Highwood Mountains, Mont 11. Little Belt Mountains, Mont 12. Crazy Mountains, Mont. 13. Red Hill, N.H.

14. Beemerville, N.J.

15. Cornudas Mountains, N. Mex.

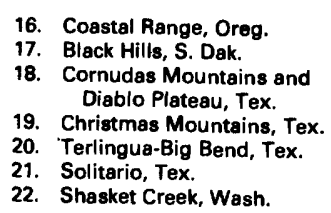

18. Cornudas Mountains and 19. Christmas Mountains, Tex.

20. Terlingua-Big Bend, Tex.

22. Shasket Creek, Wash

FIGURE 3. - Major nepheline syenite and phonolite deposits in the conterminous United States. Modified from National Research Council (1979, fig. 5.16). Number 17 is the only phonolite deposit plotted. Deposit sizes are provided in table 9.

\section{SOUTH AFRICA}

Nepheline-bearing rocks occur at several places in South Africa (Allen and Charsley, 1968; Mathias, 1974). Both nepheline syenite and phonolite are associated with several masses of alkalic rocks that are close to or within the Bushveld Complex in Transvaal. Nepheline-bearing rocks in the Spitskop area, eastern Transvaal, contain as much as 20.5 percent alumina (Brabers, 1974, table 8). In addition, nepheline syenite and associated carbonatite make up one of the major intrusive rock types in southwestern Africa.

\section{UNITED KINGDOM}

The United Kingdom has only one nepheline syenite deposit of economic importance; it is the Loch Borolan alkalic complex near Ledmor in Sutherland County, Scotland (Allen and Charsley, 1968, p. 45-47). Red syenite is the most common rock type in the igneous complex, and it contains less than 20 percent alumina. The less abundant gray nepheline syenite contains nearly 23 percent alumina (table 8).

\section{U.S.S.R.}

In the Kola Peninsula of the U.S.S.R., two large bodies of nepheline syenite (fig. 5 ) are separated by Lake Umbozero (Allen and Charsley, 1968). The Lovozero massif underlies $650 \mathrm{~km}^{2}$ and has not been mined. The Khibiny massif underlies $1,327 \mathrm{~km}^{2}$ and is the source of apatite and nepheline. The alumina contents of the nepheline syenite from the Lovozero and Khibiny mas- 
TABLE 9.-Major nepheline syenite and phonolite deposits in the United States

[Modified from Barker (1974) and National Research Council (1979, table 5.12). Dash (-), data not available]

\begin{tabular}{|c|c|c|c|c|c|c|c|}
\hline $\begin{array}{l}\text { Locality } \\
\text { number } \\
\text { in } \\
\text { figure } 3\end{array}$ & $\begin{array}{c}\text { Nepheline syenite } \\
\text { or } \\
\text { phonolite deposit }\end{array}$ & County & State & $\begin{array}{l}\text { Area } \\
\left(\mathrm{km}^{2}\right)\end{array}$ & $\begin{array}{l}\mathrm{Al}_{2} \mathrm{O}_{3} \\
\text { content } \\
\text { (weight } \\
\text { percent) }\end{array}$ & Rock type & References \\
\hline & Selawik Hills . . . . . . . & - & Alaska ........... & 200 & 22 & Nepheline syenite ..... & $\begin{array}{l}\text { Patton and Miller, 1968; } \\
\text { Miller, } 1972 .\end{array}$ \\
\hline & Granite Mountain. . . . . . & - & Alaska ... & 9.5 & - & Nepheline syenite .... . & Miller, 1972. \\
\hline & St. Lawrence Island ... & - & Alaska .......... & $44^{*}$ & $21-23$ & Nepheline syenite .... . & Csejtey and Patton, 1974. \\
\hline 1 & Bauxite .......... & Pulaski, Saline. .... & Arkansas ......... & 750 & $18-21$ & Nepheline syenite ..... & $\begin{array}{l}\text { Gordon and others, 1958; } \\
\text { Marks and Jackson, } 1975 .\end{array}$ \\
\hline 2 & Magnet Cove........ & Hot Spring. . . . . . . & Arkansas........ & 12 & 20 & $\begin{array}{l}\text { Sphene and garnet } \\
\text { nepheline syenite. }\end{array}$ & Erickson and Blade, 1963. \\
\hline 3 & Potash Sulfur Springs . . & Garland ......... & Arkansas ........ & 2 & - & Nepheline syenite .... . & Hollingsworth, 1967. \\
\hline 4 & Tin Mountain. ......... & Inyo . . . . . . . & California......... & - & 22 & Nepheline syenite .... . & McAllister, 1952. \\
\hline 5 & Iron Hill. . . . . . . . . & Gunnison ......... & Colorado ........ & 30 & - & Nepheline syenite .... . & Temple and Grogan, 1965. \\
\hline 6 & McClure Mountain..... & Fremont. ........ & Colorado ........ & 50 & - & Nepheline syenite .... & Parker and Hildebrand, 1963. \\
\hline 7 & South Park ........ & Park. ......... & Colorado ........ & - & 17 & Analcime syenite ..... & Jahns, 1938. \\
\hline 8 & Litchfield. . . . . . . . . & Kennebec. . . . . . . . & Maine. . . . . . . . . & 6 & - & Nepheline syenite . . . . & Barker, 1965. \\
\hline 9 & Bearpaw Mountains.... & Hill, Blaine . . . . & Montana......... & 780 & 18 & Nepheline syenite .... & $\begin{array}{l}\text { Pecora, 1942; Hearn and } \\
\text { others, } 1964 .\end{array}$ \\
\hline 10 & Highwood Mountains. . . & $\begin{array}{l}\text { Cascade, Chouteau, } \\
\text { Judith Basin. }\end{array}$ & Montana. ........ & 400 & 18 & Nepheline syenite ..... & Burgess, 1941. \\
\hline 11 & $\begin{array}{l}\text { Little Belt Mountains } \\
\text { (Otter Creek). }\end{array}$ & Meagher. ........ & Montana......... & - & - & $\begin{array}{l}\text { Analcime nepheline sye- } \\
\text { nite. }\end{array}$ & Weed and Pirsson, 1900. \\
\hline 12 & Crazy Mountains . . . . . . & Park. ... & Montana......... & 25 & 17 & Nepheline syenite .... . & Wolff, 1938. \\
\hline 13 & Red Hill. .......... & Carroll.......... & New Hampshire ... & $7.4^{*}$ & - & $\begin{array}{l}\text { Nepheline sodalite } \\
\text { syenite. }\end{array}$ & Quinn, 1937; Size, 1973. \\
\hline 14 & Beemerville . . . . . . . . & Sussex . . . . . . . & New Jersey . . . . . . & 2 & $20-22$ & Nepheline syenite ..... & Maxey, 1976. \\
\hline 15 & $\begin{array}{l}\text { Cornudas Mountains } \\
\text { (Wind Mountain). }\end{array}$ & Otero $\ldots \ldots \ldots \ldots$ & New Mexico...... & $8^{*}$ & - & $\begin{array}{l}\text { Porphyritic analcime } \\
\text { nepheline syenite. }\end{array}$ & Holser, 1959. \\
\hline 16 & $\begin{array}{l}\text { Coastal Range } \\
\text { (Blodgett Peak). }\end{array}$ & Lincoln. . . . . . . . & Oregon.......... & 250 & 19 & $\begin{array}{l}\text { Nepheline analcime } \\
\text { syenite. }\end{array}$ & Snavely and Wagner, 1961. \\
\hline 17 & Black Hills. . . . . . . . & Lawrence. & South Dakota. ... . . & 25 & 20 & Phonolite ........ & Darton and Paige, 1925. \\
\hline 18 & $\begin{array}{l}\text { Cornudas Mountains } \\
\text { and Diablo Plateau. }\end{array}$ & Hudspeth... & Texas.......... & 20 & 18 & $\begin{array}{l}\text { Nepheline analcime } \\
\text { syenite. }\end{array}$ & $\begin{array}{l}\text { Gross, 1965; Hodges, } 1975 ; \\
\text { Barker, 1977; Barker and } \\
\text { Hodges, 1977; Barker and } \\
\text { others, 1977. }\end{array}$ \\
\hline 19 & Christmas Mountains... & Brewster.. & Texas.......... & 10 & $18-19$ & Nepheline syenite ..... & $\begin{array}{l}\text { Swadley, 1958; Jenkins, 1959; } \\
\text { Joesten, } 1977 \text {. }\end{array}$ \\
\hline 20 & $\begin{array}{l}\text { Terlingua-Big Bend } \\
\text { (Sawmill Mountain). }\end{array}$ & Brewster. . & Texas........... & 500 & $18-19$ & Analcime syenite... . & Yates and Thompson, 1959. \\
\hline 21 & Solitario........... & $\begin{array}{l}\text { Brewster, } \\
\text { Presidio. }\end{array}$ & Texas........... & .2 & 18 & Analcime syenite... & Lonsdale, 1940. \\
\hline 22 & Shasket Creek....... . & Ferry..... & Washington...... & 2 & - & Nepheline(?) syenite . . . & Parker and Calkins, 1964. \\
\hline
\end{tabular}

* Actual area of exposed or shallowly buried nepheline syenite. Other values relate to area of the alkalic complex, of which nepheline syenite may represent only a small portion.

sifs average 17.39 and 21.26 percent, respectively (Gerasimovsky and others, 1974, table 2). The nepheline concentrate obtained by removal of apatite consists of 90-93 percent nepheline. According to Buroš and Wagner (1978), the major components of the concentrate are 29.5 percent $\mathrm{Al}_{2} \mathrm{O}_{3}, 43.5$ percent $\mathrm{SiO}_{2}, 3.5$ percent $\mathrm{Fe}_{2} \mathrm{O}_{3}$, 12.5 percent $\mathrm{Na}_{2} \mathrm{O}$, and about 7.8 percent $\mathrm{K}_{2} \mathrm{O}$. Alumina is recovered from the concentrate along with cement, soda $\left(\mathrm{Na}_{2} \mathrm{O}\right)$, and potash $\left(\mathrm{K}_{2} \mathrm{O}\right)$, whose recovery make the process economical.

The apatite-nepheline bodies being mined are in the southwestern part of the Khibiny massif in a curved zone $13 \mathrm{~km}$ long and as much as $200 \mathrm{~m}$ thick (Kalinkin, 1969). The reserves of the apatite-nepheline ore in the Khibiny massif are estimated to be 2.7 billion metric tons, from which 500 million metric tons of nepheline concentrate is recoverable (Buroš and Wagner, 1978, p. 45).
In Siberia, huge massifs of nepheline-bearing rocks are near Kemerovo and in the Krasnoyarsk region (fig. 5). Near Kemerovo are the Goryachegorsk and KiyaShaltyr massifs. The Kiya-Shaltyr deposit has been mined, and the Goryachegorsk deposit has been prepared for mining (Mikhaylov and others, 1977). In the Krasnoyarsk region, the Kiya complex of nepheline and alkalic syenites is near the Yenisey River (Mikhaylov and others, 1977), and nepheline syenite containing 21 percent alumina has been discovered in the Srednyaya and Pravaya Noyba interstream areas of the northern Yenisey Range (Nozhkin and Cherepnin, 1967). These nepheline syenite occurrences seem to correspond to the Central Tartar massif of Allen and Charsley (1968, p. 105). The Sangilen Range in southeastern Tuva contains nepheline rocks (Allen and Charsley, 1968, p. 106). The Synnyr complex north of Lake Baykal consists of 10 


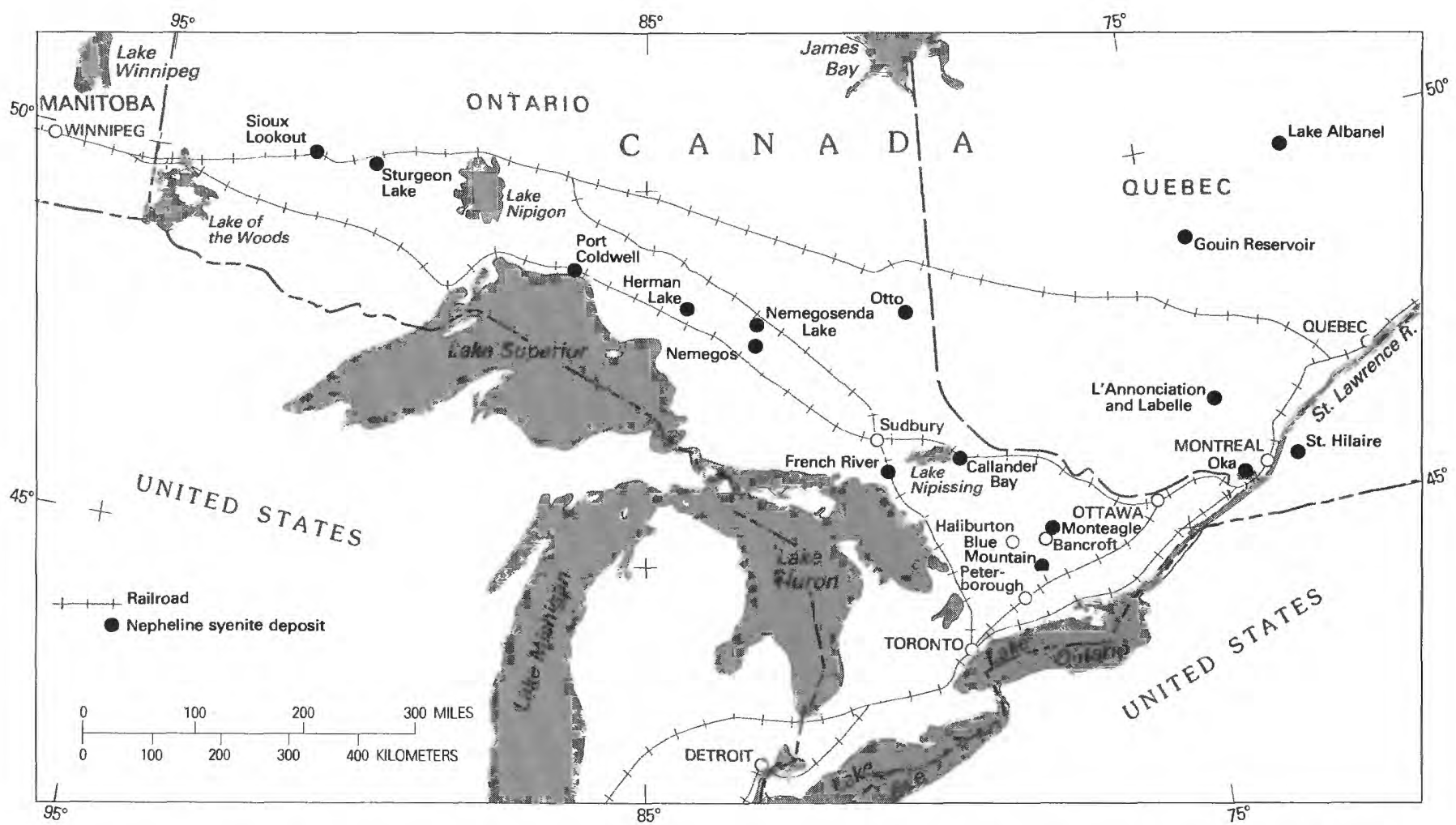

Figure 4.-Nepheline syenite deposits in Ontario and Quebec Provinces, Canada. Modified from Allen and Charsley (1968, fig. 6).

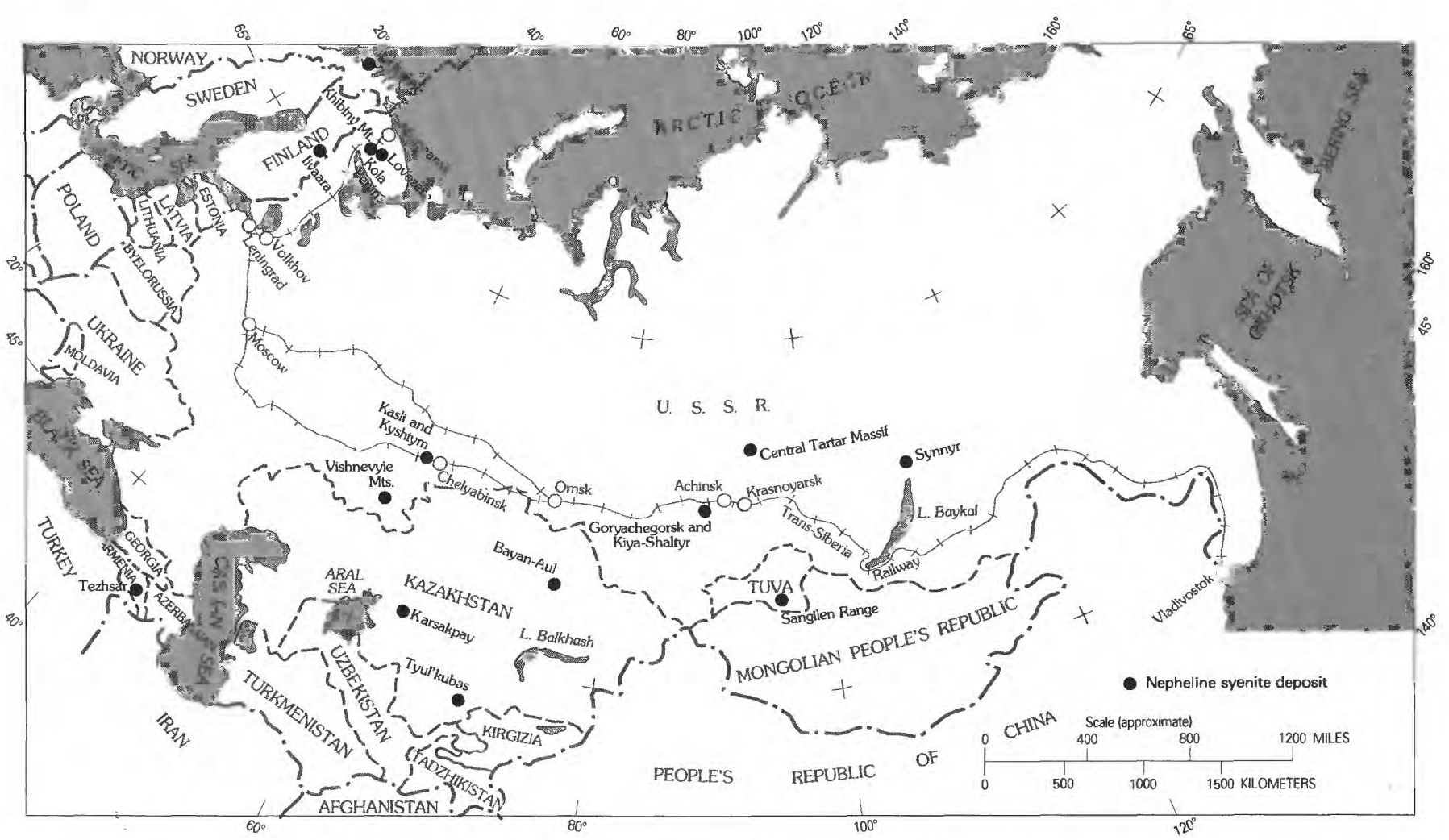

FIGURE 5. - Major nepheline syenite deposits in the U.S.S.R., Finland, and Norway. Modified from Allen and Charsley (1968) and Mikhaylov and others (1977). 
alkalic massifs, one of which contains the Synnyr deposit of nepheline and pseudoleucite syenites (Mikhaylov and others, 1977). Mikhaylov and others (1977) described other nepheline syenite massifs in Siberia.

In Kazakhstan, three areas are known to contain deposits of nepheline syenite-the Bayan-Aul, Tyul'kubas, and Karsakpay massifs (fig. 5) The Bayan-Aul nepheline syenites consist of pipes and dikes containing 26-44 percent nepheline; one sample contained 20 percent alumina (Allen and Charsley, 1968). The Tyul'kubas nepheline syenite contains 20-22 percent nepheline. One sample of nepheline syenite from the Karsakpay massif contained 24 percent alumina (Allen and Charsley, 1968, p. 107).

Several deposits of nepheline syenite occur in the southern Ural Mountains. One sample from the Vishnevyie Mountains near Orsk contained almost 22 percent alumina in rock that usually contains 25 percent nepheline and 65 percent alkalic feldspar and sodic plagioclase (Allen and Charsley, 1968, p. 107). Other nepheline syenite deposits are Kasli and Kyshtym near Chelyabinsk. Attempts have been made to beneficiate the nepheline syenite from these areas, but the results were not promising (Allen and Charsley, 1968).

\section{OTHER COUNTRIES}

Nepheline syenite and phonolite occur in many countries in addition to those mentioned above. Allen and Charsley (1968) described these rocks in 39 more countries, and probably their list is incomplete. The Sarhad Development Authority of Pakistan has proven 6 billion metric tons of nepheline syenite near Mardan (U.S. Embassy, Islamabad, Pakistan, written commun., 1983). In Greenland, nepheline syenite occurs in two large masses, each underlying more than $100 \mathrm{~km}^{2}$ (Allen and Charsley, 1968, p. 127-128; Upton, 1974). The only nepheline-bearing rocks in Finland are in the livaara intrusion (fig. 5) southeast of Kuusamo, near the Soviet border (Shaikh, 1977, p. 194). Their iron content makes the Iivaara rocks unlikely to be mined (Allen and Charsley, 1968, p. 86). In Zimbabwe, nepheline syenite is present in three igneous complexes in the Sabi River valley southeast of Harare (Allen and Charsley, 1968, p. 56).

Phonolite occurs in four areas in the Federal Republic of Germany, but only the extensive deposits in the Eifel region are mined (U.S. Bureau of Mines, 1939; Allen and Charsley, 1968, p. 87). In Czechoslovakia, phonolite deposits occur in the České Stř̌edohoří Mountains, about $72 \mathrm{~km}$ northwest of Prague, between the towns of Most and Bilina (Allen and Charsley, 1968, p. 83).

\section{ALUMINOUS IGNEOUS ROCKS-LEUGITE-BEARING ROCKS}

Leucite $\left(\mathrm{KAlSi}_{2} \mathrm{O}_{6}\right)$ is a feldspathoid mineral having a composition of 21.5 percent $\mathrm{K}_{2} \mathrm{O}, 23.5$ percent $\mathrm{Al}_{2} \mathrm{O}_{3}$, and 55.0 percent $\mathrm{SiO}_{2}$. It is common in fine-grained or porphyritic volcanic rocks; in some regions, it is in hypabyssal rocks.

Large leucite deposits are in the volcanic rocks in the Latium region and at Mount Vesuvius, Italy (Landi, 1975). Abbruzzese and Rinelli (1981, p. 23-24) estimated that the total alumina in these rocks is several billion metric tons. In 1918, it was estimated that the leucitebearing rocks in Italy contain enough alumina and potash to supply the world for several centuries (Blanc, 1931, $p$. 50). According to Blanc (1931), leucite-bearing rocks having particularly favorable physical and chemical compositions for the extraction of alumina are in the region of the Roccamonfina Volcano near Sessa Aurunca. Massacci (1978, p. 558) estimated that this region holds 100 million to 1 billion metric tons of leucite-bearing rock containing 20-22 percent $\mathrm{Al}_{2} \mathrm{O}_{3}$ and $10-11$ percent $\mathrm{K}_{2} \mathrm{O}$. Another region extends from Mount Cimini and the surrounding mountains to the crater of Vico. A part of this district near Civita Castellana contains several hundred million metric tons of leucite-bearing rocks (Massacci, 1978, p. 559 ).

Leucite occurs in several other countries. The largest known body of leucite-bearing rock in the United States is in the Leucite Hills, Sweetwater County, Wyo. Resource estimates indicate the presence of nearly 2 billion metric tons containing 200 million metric tons of $\mathrm{Al}_{2} \mathrm{O}_{3}$ and 200 million metric tons of $\mathrm{K}_{2} \mathrm{O}$ (Schultz and Cross, 1912, p. 35). Leucite-bearing rocks also occur in Sussex County, N.J.; near Magnet Cove, Ark.; in the Absaroka Range, Wyo.; and in the Bearpaw and Highwood Mountains, Mont. (Pirsson, 1905; Ford, 1932, p. 551; Burgess, 1941). Leucite is present in Western Australia (Wade and Prider, 1940); near Gnjilane, Kosovo, Yugoslavia (Logomerac and Crnko, 1981); and in southwestern Uganda and neighboring Zaire (Sahama, 1952).

Pseudoleucite-bearing rocks in the northern Baykal region, U.S.S.R., have been investigated as a possible source of alumina (Kostyun, 1975). Pseudoleucite is a pseudomorph after leucite composed of a mixture of nepheline, orthoclase, and analcime. Pseudoleucite also occurs with nepheline syenite in Arkansas, Montana, and Brazil.

\section{DAWSONITE-BEARING ROCKS}

Dawsonite, $\mathrm{NaAl}(\mathrm{OH})_{2} \mathrm{CO}_{3}$, a colorless or white, acidsoluble mineral, occurs in small needlelike crystalline aggregates or as fine-grained to microscopic crystals in 
several types of rocks. Dawsonite contains, by weight, 35.4 percent $\mathrm{Al}_{2} \mathrm{O}_{3}$ or 18.7 percent aluminum metal. When heated, dawsonite loses hydroxyl water and carbon dioxide to form a water-soluble sodium aluminate (Schmidt-Collerus and Hollingshead, 1968). Until the discovery of dawsonite in the Eocene oil shale of Colorado, the mineral was known to occur in small amounts at only a few localities in the world (Smith and Milton, 1966). Alumina for production of aluminum metal and sodium aluminate for use in water-pollution control are potential products of the dawsonite from oil shale (Hite and Dyni, 1967). This section summarizes the pertinent information on dawsonite as an aluminum resource.

\section{UNITED STATES}

The principal dawsonite resources in the United States occur in the oil shale of the Parachute Creek Member of the Eocene Green River Formation in northwestern Colorado. In some beds, large quantities of dawsonite are mixed with nahcolite $\left(\mathrm{NaHCO}_{3}\right)$, several other minerals, and kerogen (organic matter that yields oil when distilled) in the oil shale. In addition to kerogen, the oil shale in the Parachute Creek Member is made up chiefly of quartz, calcite, dolomite, and feldspar (table 10); analcime and clay minerals are minor constituents. The clay minerals present are illite and a trace amount of mixed-layer clays; the mixed-layer clays consist of illite and montmorillonite. The lack of kaolinite and the presence of illite suggest that the sedimentary material was deposited in a lake that had a reducing environment of slightly alkaline, brackish to saline waters. As discussed below, the oil shale contains potentially extractable alumina in some form other than dawsonite (Smith, 1980).

A great deal of research and money has been invested in finding ways to extract oil from the Green River Formation oil shale. Most of the effort has been concentrated in the Piceance Creek basin in northwestern Colorado. At least 45 different minerals have been identified from the Green River Formation (Milton and Eugster, 1959), and those unique to the Green River Formation are shortite, eitelite, bradleyite, reedmergnerite, garrelsite, and loughlinite. Parts of the Parachute Creek Member contain as much as 15-25 percent dawsonite. Large dawsonite concentrations have not been found in the Green River Formation in other basins in Colorado, Utah, and Wyoming.

For many years, the chemical analyses of the oil shale have been known to contain more alumina than could be accounted for by the aluminous minerals found in the oil shale (Desborough and Pitman, 1974, p. 85). This excess alumina was thought to be present in the form of gibbsite (DeVoto and others, 1970). Milton and others (1975) identified nordstrandite, a polymorph of gibbsite, in the oil shale. Smith (1980, p. 2) noted that "Nordstrandite in oil shale occurs everywhere with dawsonite." However, both minerals may not always be present together because Asai and others (1983, p. 4) described the Saline zone as containing 12 percent dawsonite (4 percent extractable alumina), essentially no nahcolite, and no detectable amounts of nordstrandite. In addition, three samples from the Parachute Creek Member contain dawsonite and no nordstrandite (table 10). Zen and Hammarstrom (1975) concluded that X-ray diffraction methods are not reliable for determining the amount of nordstrandite present in oil shale, and Desborough and others $(1974$, p. 6) noted that amorphous alumina is present. Therefore, the problems concerning the form in which the excess alumina occurs make it clear that much remains to be learned about aluminum in the Green River Formation oil shale. The reasons for the shortcomings in our knowledge of aluminum in shale include the following: (1) much of the dawsonite is very fine grained and cannot be isolated for study from the other finegrained minerals and organic matter; (2) variable amounts of aluminum in the shale are caused by the feldspars, by other nonclay alumina minerals, and by the clay mineral illite; and (3) most of the data on mineralogy and geochemistry of oil shale have been acquired by analyzing ashed samples (samples ashed in oxygen plasma at about $100^{\circ} \mathrm{C}$ ), and little is known about what happens during ashing to aluminous minerals associated with organic matter.

\section{Geology}

The Green River Formation is composed of dark shale and magnesian marl, both of which yield oil on distillation (Donnell, 1961, p. 847). Sandstone, siltstone, and limestone beds are also present in parts of the formation. Bedding is remarkably regular and tends to persist throughout large areas. In the Piceance Creek basin, the formation can be divided into five members, the first four of which are, from oldest to youngest, the Douglas Creek, Garden Gulch, Parachute Creek, and Evacuation Creek (Bradley, 1931, p. 9); the fifth member, the Anvil Points, is present along the east side of the basin and is laterally equivalent to the Douglas Creek, the Garden Gulch, and part of the Parachute Creek (Donnell, 1961, p. 848). The Parachute Creek Member is much richer in oil shale, dawsonite, and nahcolite than the other members.

The Parachute Creek Member ranges in thickness from about $260 \mathrm{~m}$ on the margins of the Piceance Creek basin to about $550 \mathrm{~m}$ in the central part of the basin (Hite and Dyni, 1967, p. 26-28). The lower part of the Parachute Creek Member is called the Saline zone. It is at 
TABLE 10.-Mineral composition of samples from four sections of the Parachute Creek Member of the Green River Formation, Piceance Creek basin, northwestern Colorado

[Modified from Hosterman and Dyni (1972, table 1). Mineral designations: Dol, dolomite; Cal, calcite; Daw, dawsonite; Qtz, quartz; Kfs, potassium feldspar; Naf, sodium feldspar, Anl, analcime; Ill, illite; Mix, mixed-layer clay. Depths were measured in feet. Do., ditto; tr, trace; dash (-), not detected]

\begin{tabular}{|c|c|c|c|c|c|c|c|c|c|c|c|}
\hline \multirow[t]{2}{*}{ Rock type } & \multirow[t]{2}{*}{ Color $^{1}$} & \multicolumn{3}{|c|}{$\begin{array}{c}\text { Carbonates }^{2} \\
\text { (percent) }\end{array}$} & \multicolumn{6}{|c|}{$\begin{array}{c}\text { Noncarbonates }^{3} \\
\text { (percent) }\end{array}$} & \multirow[t]{2}{*}{ Sample position } \\
\hline & & Dol & Cal & Daw & Qtz & Kfs & Naf & Anl & Ill & Mix & \\
\hline \multicolumn{12}{|c|}{ Sec. 36 , T. 7 S., R. 97 W. } \\
\hline Oil shale, dolomitic & $(5 Y 6 / 2)$ & 55 & - & - & 20 & 5 & 10 & 5 & 5 & $\operatorname{tr}$ & $15.5 \mathrm{ft}(4.72 \mathrm{~m})$ above Mahogany zone. \\
\hline Do. & $(2.5 \mathrm{Y} 6 / 2)$ & 40 & 10 & - & 25 & 5 & 10 & 5 & 5 & $\operatorname{tr}$ & $2.5 \mathrm{ft}(0.76 \mathrm{~m})$ above Mahogany zone. \\
\hline Do. & $(2.5 Y 6 / 1)$ & 40 & 15 & - & 20 & 5 & 10 & 5 & 5 & $\operatorname{tr}$ & $3 \mathrm{ft}(0.9 \mathrm{~m})$ below Mahogany zone. \\
\hline Do. & $(2.5 \mathrm{Y} 4 / 2)$ & 35 & - & - & 30 & 5 & 20 & 5 & 5 & $\operatorname{tr}$ & $12.5 \mathrm{ft}(3.81 \mathrm{~m})$ below Mahogany zone. \\
\hline \multicolumn{12}{|c|}{ Sec. 6, T. 4 S., R. 94 W. } \\
\hline Oil shale, dolomitic & $(2.5 \mathrm{Y} 6 / 1)$ & 30 & 5 & - & 30 & 15 & 10 & $\operatorname{tr}$ & 10 & $\operatorname{tr}$ & $46.5 \mathrm{ft}(14.2 \mathrm{~m})$ above Mahogany zone. \\
\hline Do. & $(2.5 Y 6 / 2)$ & 50 & - & - & 20 & $\operatorname{tr}$ & 10 & 15 & 5 & $\operatorname{tr}$ & $39 \mathrm{ft}(11.9 \mathrm{~m})$ above Mahogany zone. \\
\hline Do. & $(2.5 Y 5 / 2)$ & 40 & 10 & - & 20 & 5 & 10 & 10 & 5 & $\operatorname{tr}$ & $22.4 \mathrm{ft}(6.83 \mathrm{~m})$ above Mahogany zone. \\
\hline Do. & $(2.5 Y 4 / 2)$ & 30 & 10 & - & 25 & $\operatorname{tr}$ & 15 & 10 & 10 & $\operatorname{tr}$ & Mahogany zone. \\
\hline \multicolumn{12}{|c|}{ Sec. 14 , T. 1 N., R. 97 W. } \\
\hline Oil shale & $(5 Y 4 / 1)$ & 15 & - & 15 & 35 & 10 & 10 & 5 & 10 & $\operatorname{tr}$ & Not available. \\
\hline Do. & $(5 \mathrm{Y} 5 / 1)$ & 10 & - & 25 & 40 & 10 & 10 & $\operatorname{tr}$ & 5 & $\operatorname{tr}$ & Not available. \\
\hline Do. & $(5 Y 5 / 1)$ & 20 & - & 20 & 40 & 10 & 5 & $\operatorname{tr}$ & 5 & $\operatorname{tr}$ & Not available. \\
\hline Oil shale, dolomitic & $(2.5 \mathrm{Y} 6 / 1)$ & 40 & 5 & - & 20 & 5 & 15 & 10 & 5 & $\operatorname{tr}$ & $16.9 \mathrm{ft}(5.15 \mathrm{~m})$ above Mahogany zone. \\
\hline Do. & $(2.5 \mathrm{Y} 5 / 2)$ & 40 & 5 & - & 25 & 5 & 5 & 10 & 10 & $\operatorname{tr}$ & $4.3 \mathrm{ft}(1.3 \mathrm{~m})$ above Mahogany zone. \\
\hline Do. & $(5 \mathrm{Y} 4 / 1)$ & 25 & $\operatorname{tr}$ & - & 35 & 5 & 20 & 5 & 10 & $\operatorname{tr}$ & $1 \mathrm{ft}(0.3 \mathrm{~m})$ above Mahogany zone. \\
\hline Do. & $(5 \mathrm{Y} 5 / 1)$ & 25 & 5 & - & 35 & 5 & 10 & 10 & 10 & $\operatorname{tr}$ & Mahogany zone. \\
\hline Do. & $(5 \mathrm{Y} 4 / 1)$ & 25 & - & - & 40 & 10 & 5 & 10 & 10 & tr & $20 \mathrm{ft}(6.1 \mathrm{~m})$ below Mahogany zone. \\
\hline \multicolumn{12}{|c|}{ Sec. 34 , T. 2 S., R. 100 W. } \\
\hline Oil shale, dolomitic & $(5 \mathrm{Y} 6 / 2)$ & 30 & 10 & - & 20 & 5 & 10 & 15 & 10 & $\operatorname{tr}$ & $333.2 \mathrm{ft}(101.6 \mathrm{~m})$ above Mahogany zone. \\
\hline Do. & $(5 \mathrm{Y} 6 / 2)$ & 50 & $\operatorname{tr}$ & - & 20 & 5 & 10 & 10 & 5 & $\operatorname{tr}$ & $200.4 \mathrm{ft}(61.08 \mathrm{~m})$ above Mahogany zone. \\
\hline Do. & $(2.5 \mathrm{Y} 6 / 2)$ & 40 & 10 & - & 20 & 5 & 10 & 10 & 5 & $\operatorname{tr}$ & $15.5 \mathrm{ft}(4.72 \mathrm{~m})$ above Mahogany zone. \\
\hline Do. & $(5 \mathrm{Y} 4 / 2)$ & 30 & 5 & - & 25 & 5 & 20 & 10 & 5 & $\operatorname{tr}$ & Mahogany zone. \\
\hline Do. & $(10 \mathrm{YR} 5 / 1)$ & 40 & - & - & 15 & 15 & 15 & 5 & 10 & $\operatorname{tr}$ & $15.7 \mathrm{ft}(4.79 \mathrm{~m})$ below Mahogany zone. \\
\hline Do. & $(5 \mathrm{Y} 6 / 2)$ & 50 & - & - & 25 & 5 & 5 & 5 & 10 & $\operatorname{tr}$ & $334.7 \mathrm{ft}(102.1 \mathrm{~m})$ below Mahogany zone. \\
\hline Oil shale & $(10 \mathrm{YR} 4 / 2)$ & 40 & - & - & 35 & $\left({ }^{4}\right)$ & $\left({ }^{4}\right)$ & 5 & 10 & 5 & $405.3 \mathrm{ft}(123.6 \mathrm{~m})$ below Mahogany zone. \\
\hline
\end{tabular}

${ }^{1}$ Rock-color designations from Munsell Color Company (1929-60).

${ }^{2}$ The percentage of total carbonate minerals is based on weight loss after dilute $\mathrm{HCl}$ treatment. The kerogen content of the rock was not determined.

${ }^{3}$ The percentages of noncarbonate minerals are based on the peak-height ratios of the major peaks on the X-ray diffraction traces.

${ }^{4}$ Potassium feldspar and sodium feldspar total 5 percent.

least $215 \mathrm{~m}$ thick in the depositional center of the basin and contains the richest known dawsonite beds in the Green River Formation. The Saline zone penetrated by the USBM mine shaft in Horse Draw (fig. 6) was described by Cole and others (1982, fig. 6), who showed the dawsonitic oil shale to be about $130 \mathrm{~m}$ thick. Three thin persistent beds containing nahcolite are present near the base of the Saline zone (fig. 7). In the depositional center of the basin, two lenticular units of halite $(\mathrm{NaCl})$, each more than $30 \mathrm{~m}$ thick, are present in the upper part of the Saline zone. These units include thin layers of nahcolite that occur in cyclic fashion. Accessory minerals associated with the halite include wegscheiderite, $\mathrm{Na}_{2} \mathrm{CO}_{3} \cdot 3 \mathrm{NaHCO}_{3}$, shortite, $\mathrm{Na}_{2} \mathrm{CO}_{3} \cdot 2 \mathrm{CaCO}_{3}$, northupite, $\mathrm{Na}_{2} \mathrm{CO}_{3} \cdot \mathrm{MgCO}_{3} \cdot \mathrm{NaCl}$, searlesite, $\mathrm{NaBSi}_{2} \mathrm{O}_{6} \cdot \mathrm{H}_{2} \mathrm{O}$, and possibly trona, $\mathrm{Na}_{2} \mathrm{CO}_{3} \cdot \mathrm{NaHCO}_{3} \cdot 2 \mathrm{H}_{2} \mathrm{O}$ (Hite and Dyni, 1967, p. 31). The top of the Saline zone is marked by a dissolution surface on the upper halite unit.
Overlying the Saline zone is the Leached zone, which is several hundred meters thick. The Leached zone consists of broken and brecciated oil shale that has abundant solution cavities. Most of the soluble saline minerals have been removed by ground water. The zone is water bearing, and water-soluble minerals are probably still being removed. The drill cores from $\mathrm{CR}-1$ and $\mathrm{CR}-2$ (fig. 6) penetrated several dawsonitic units (Donnell and Smith, 1980, fig. 3), which are mostly in the lower half of the Leached zone. The concentration of dawsonite in the Leached zone is generally not as great as that in the underlying Saline zone.

Above the Leached zone is the Mahogany zone, which includes the resistant Mahogany ledge in outcrops; the Mahogany zone is bounded by the A groove (above) and the B groove (fig. 7). The grooves are the reentrants in cliffs formed by the erosion of thin tuffaceous beds. The Mahogany zone is about $61 \mathrm{~m}$ thick locally (Brobst and 

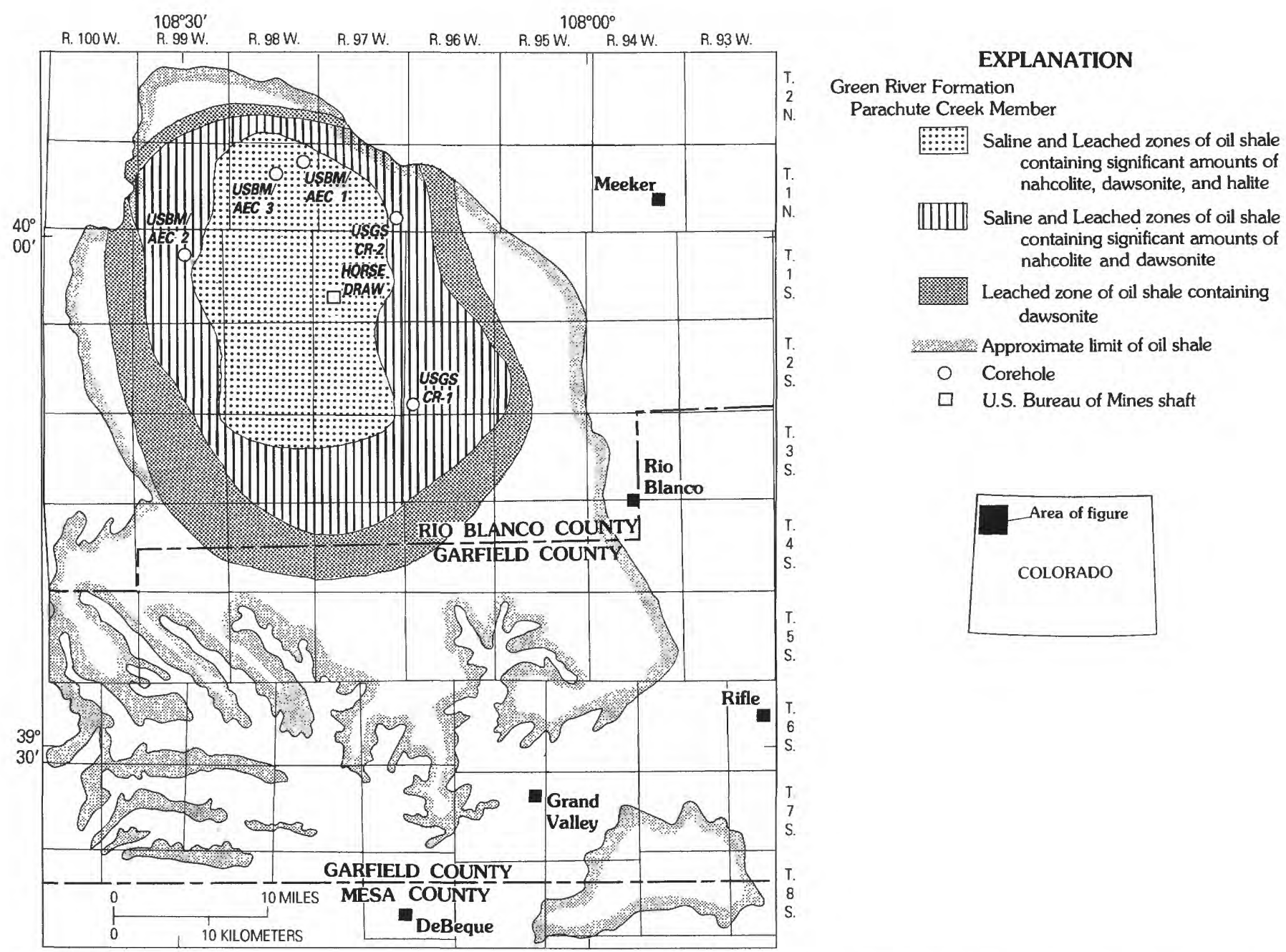

FiguRE 6.-Distribution of nahcolite and dawsonite in the Parachute Creek Member of the Green River Formation, Piceance Creek basin, northwestern Colorado. Modified from Weichman (1974b, fig. 3) and Dean and others (1981, fig. 1).

Tucker, 1973, p. 5), and it is one of the richest oil shale units in the Parachute Creek Member (Stanfield and others, 1957). Hosterman and Dyni (1972, table 1; this report, table 10) found that three surface samples from the Mahogany ledge lacked dawsonite, and Brobst and Tucker (1973, tables 4 and 5) also found no dawsonite in most surface samples. Desborough and others (1974) found dawsonite in core samples of the Mahogany zone, and Beard and others (1974, p. 103) noted that small amounts of dawsonite are present in the Mahogany zone.

The Parachute Creek Member above the Mahogany zone is called the Upper Oil Shale zone (Cole and others, 1982, fig. 3) and consists chiefly of tuffaceous marl and oil shale (Donnell, 1961, p. 856-857). These beds have numerous cavities resulting from the solution of crystals of gypsum, anhydrite, and saline minerals. Brobst and Tucker (1973, fig. 6) found only a minor amount of dawsonite in this zone.
All three saline minerals, nahcolite, dawsonite, and halite, are present in the Saline and Leached zones in the center of the Piceance Creek basin (fig. 6). Around this central area are an inner belt, in which only nahcolite and dawsonite are present, and an outer belt of Leached zone, in which only dawsonite is present. Dawsonite in the Saline zone crops out in the northern part of the basin (Brobst and Tucker, 1973, p. 42), but nahcolite has been found only in the subsurface (Dyni, 1974; Desborough and Pitman, 1974). According to Cole and others (1982), nahcolite is most abundant in oil-rich zones, and dawsonite tends to be more abundant in the zones that are lean in oil shale. The bulk sample of dawsonitic oil shale investigated by Asai and others (1983) and White and others (1985) was taken from the $640-\mathrm{m}$ level of the USBM mine shaft; it was about 12 percent dawsonite, which is equivalent to about 4 percent recoverable alumina. According to Cole and others (1982, fig. 6), the 


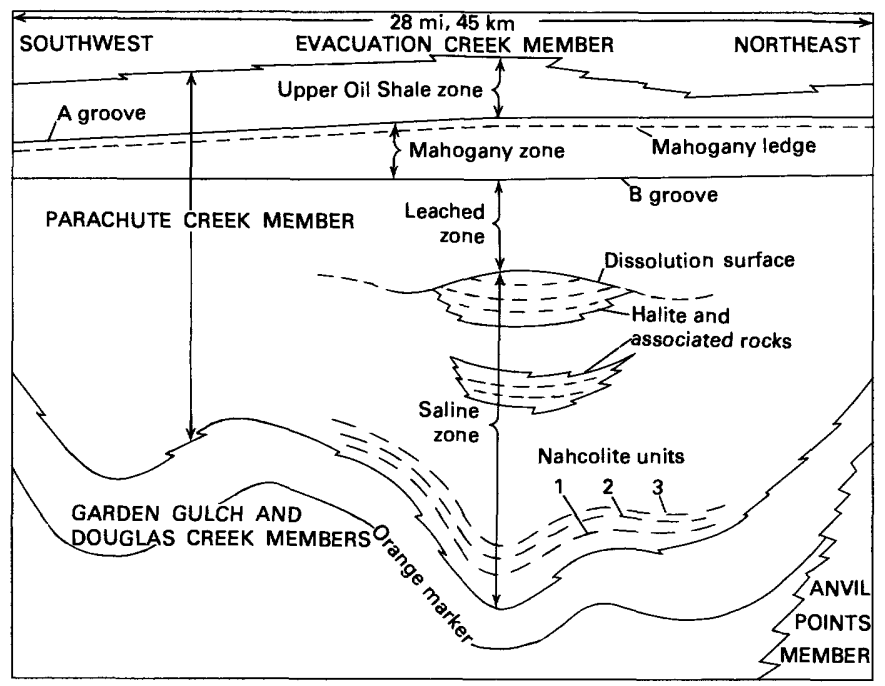

FIgURE 7.-Diagrammatic cross section through the Green River Formation in the Piceance Creek basin, northwestern Colorado. Modified from Dyni and Hite (1968, fig. 2).

beds at this level are in lean oil shale of the Saline zone and contain only a small amount of nahcolite and a little more than an average amount of dawsonite.

\section{RESOURCES}

Estimates of the dawsonite resources in the Piceance Creek basin have been made. Dyni and Hite $(1968$, p. 23) and the U.S. Department of the Interior $(1968$, p. 27) listed the total dawsonite in the basin as 24.5 billion metric tons containing 8.5 billion metric tons of alumina. Beard and others (1974, p. 103-108) and Patterson and Dyni $(1973$, p. 40) estimated the total dawsonite in the Saline zone of the Parachute Creek Member to be 17 billion metric tons, which could yield 6 billion metric tons of alumina. This estimate excluded the small amounts of dawsonite in the Mahogany and Leached zones.

The estimate by Beard and others (1974, p. 103-108, table 1, figs. 1-11) was based on analyses of samples of the Saline zone taken from 22 drill holes. Thickness of the Saline zone sampled ranged from about $91 \mathrm{~m}$ to more than $360 \mathrm{~m}$. The average dawsonite content from 14 holes ranged from 1.9 to 5.9 percent. Oil shale having a dawsonite content of 5 percent or more underlies approximately $161 \mathrm{~km}^{2}$ in the depositional center of the basin. According to Desborough and others $(1974$, p. 6), some of the units in the center of the basin contain more than 12 percent dawsonite.

Recovery of oil from shale would be less expensive if other products could also be produced. Dawsonite and nahcolite are possible coproducts. Cameron and Jones, an engineering company, proposed that alumina (from dawsonite) and soda ash $\left(\mathrm{Na}_{2} \mathrm{CO}_{3}\right.$, from nahcolite) could be recovered as coproducts with oil from shale (Nielsen,
1969; National Materials Advisory Board, 1970, p. 45-46). The Superior Oil Company patented a process for the recovery of oil, alumina, and soda ash (Weichman, 1974a). Beard and Smith (1976) outlined a process for the in-place recovery of dawsonite and other mineral products from the Saline zone in the Piceance Creek basin.

Nahcolite has received much attention because it can remove sulfur dioxide from flue gas of coal-fired electricity-generating plants (Dyni, 1980, p. 1855). For this use, the mineral is thermally decomposed to form anhydrous sodium carbonate, which reacts with sulfur dioxide in the flue gas to form sodium sulfate. To evaluate nahcolite as a desulfurizing agent, Multi Minerals Corporation tested 500 metric tons from a bed in the Saline zone of the Parachute Creek Member of the Green River Formation (Dyni, 1980, p. 1857). This material, containing 70 percent nahcolite, removed $75-80$ percent of the sulfur from the flue gas in a coal-fired powerplant.

Because of the many mining problems in the recovery of dawsonite from the Green River Formation of the Piceance Creek basin, it is presently considered to be a hypothetical resource of aluminum. The Upper Oil Shale zone, the kerogen-rich Mahogany zone that does not contain much dawsonite, and the Leached zone would have to be mined before the underlying dawsonite-rich Saline zone could be mined. The base of the Saline zone is at a depth of about $900 \mathrm{~m}$ in the center of the basin (Beard and Smith, 1976). The Leached zone contains saline water that is the result of the dissolution of nahcolite, dawsonite, and halite. The saline water in this aquifer could be a serious problem if it were encountered during mining because it cannot be discarded into the surface drainage (Smith, 1980, p. 2). Miners of the Saline zone would have to prevent saline water inflows from the overlying Leached zone.

\section{OTHER COUNTRIES}

When dawsonite was identified in the Green River Formation, U.S.A. (Smith and Milton, 1966), it was known to occur in Montreal, Canada; Tuscany, Italy; the Drin Valley, Albania; Alger, Algeria; and the Olduvai Gorge, Tanzania. Since then, dawsonite has been found in California, where it is a daughter product of fluid inclusions in gold-quartz veins in the Alleghany district (Coveney and Kelley, 1971). It has also been found in several other countries, including (1) Canada, where dawsonite is in feldspathic sills at two localities in Quebec (Stevenson and Stevenson, 1978; Jambor and others, 1976); (2) Hungary, where dawsonite is in andesite breccia (Baksa and others, 1975); (3) Japan, where dawsonite is in fossiliferous marine mudstone associated with tuff (Aikawa and others, 1972); (4) Mauritania, where dawsonite is in analcimite in Adrar (Blanc and others, 
1971); (5) Australia, where dawsonite is in Permian marine strata (Goldbery and Loughnan, 1970) and the Singleton coal measures (Loughnan and Goldbery, 1972) in the Sydney basin and the coal measures in the Muswellbrook district, New South Wales (Loughnan and See, 1967); and (6) the U.S.S.R. (Batalin and others, 1975), where dawsonite is in the Donets, Pripet, Kuznetsk, and Solotyinsk regions. Dawsonite is present in Carboniferous rocks in the Pripet basin in Byelorussia, where it occurs in kaolinitic clays interbedded with siderite and anhydrite (Dmitriyev and others, 1975). Amounts present range from 21 to 74 percent of the rock. Dawsonite in the Kuznetsk basin is in coal-bearing rocks (Volkova and Rekshinskaya, 1975). It occurs in shales, silty shales, and carbonate rocks in amounts ranging from a few percent to as much as 40 percent of the rock (Volkova and Rekshinskaya, 1975). Dawsonite has also been found in the Carpathians (Gabinet and Lozynyak, 1975) and in the Transcarpathian region (Lazarenko and Mel'nikov, 1969). The only place in the U.S.S.R. where dawsonite occurs with sodium-bearing minerals is in the bottom sediments of the present-day lakes in the TransVolga region (Mikhaylov and others, 1977, p. 1222).

\section{ALUMINOUS PHOSPHATE ROCKS}

Many aluminous phosphate rocks result from the leaching and alteration of aluminous calcium phosphate. Slightly leached zones contain carbonate-fluorapatite, $\mathrm{Ca}_{10}\left(\mathrm{PO}_{4} \mathrm{CO}_{3}\right)_{6} \mathrm{~F}_{2-3}$ (Altschuler and others, 1956, p. 499). More thoroughly leached zones contain crandallite $\left(\mathrm{CaAl}_{3}\left(\mathrm{PO}_{4}\right)_{2}(\mathrm{OH})_{5} \cdot \mathrm{H}_{2} \mathrm{O}\right)$, which replaced apatite or kaolinite $\left(\mathrm{Al}_{2} \mathrm{Si}_{2} \mathrm{O}_{5}(\mathrm{OH})_{4}\right)$, and millisite $\left((\mathrm{Na}, \mathrm{K}) \mathrm{CaAl}_{6}\left(\mathrm{PO}_{4}\right)_{4}\right.$ $(\mathrm{OH})_{9} \cdot 3 \mathrm{H}_{2} \mathrm{O}$ ), which may have replaced montmorillonite. The most completely altered zones are dominated by wavellite, $\mathrm{Al}_{3}\left(\mathrm{PO}_{4}\right)_{2}(\mathrm{OH}, \mathrm{F})_{3} \cdot 5 \mathrm{H}_{2} \mathrm{O}$.

\section{UNITED STATES}

Aluminous phosphate rock occurs at several localities in the Southeastern United States. The principal deposits are in the land-pebble phosphate district, which is centered in Polk and Hillsborough Counties east of Tampa Bay, Florida (Catheart and Houser, 1950). The deposits extend northward through the hard-rock district, Florida (Espenshade and Spencer, 1963), into southern Georgia (Sever and others, 1967). They constitute the leached upper part of the Bone Valley Formation of Pliocene age. The leached, or aluminum phosphate, zone has a maximum thickness of about $18 \mathrm{~m}$ and overlies the calcium phosphate pebbles mined for fertilizer (Cathcart and others, 1953, p. 77). The leached zone is overlain by a blanket of sandy soil 1-6 $\mathrm{m}$ thick. The amount of overburden stripped annually during mining of the phosphate pebbles was estimated in 1957 to be 15 million metric tons (Calver, 1957, p. 52).

The leached zone, discarded by the mining operation, contains uranium in addition to phosphate and alumina, and the recovery of all three commodities may be an attractive possibility. Although much of this rock contains only 6-15 percent alumina (table 11 ), both the alumina and phosphate content can be increased by removing the quartz, which is coarser grained than the phosphatic material (Cathcart, 1963, p. 46). Aluminum phosphate coating the quartz grains would be lost unless the leached zone material were digested in $\mathrm{Na}_{2} \mathrm{CO}_{3}$ before the quartz was removed (National Materials Advisory Board, 1970, p. 52). The aluminum phosphate minerals usually make up 20-30 percent of the rock in the leached zone; of the remainder, 60 percent or more is sand-sized quartz grains (Altschuler and others, 1956).

In the early 1950's, these resources were estimated to contain 800 million metric tons of aluminum phosphate (McKelvey and others, 1953). Probably at least half of these aluminum resources have been lost as a result of mining the calcium phosphate pebbles since the estimate was made.

\section{SENEGAL}

The Thiès region, Senegal, includes the Pallo deposit, $14 \mathrm{~km}$ north of Thiès, the Lam-Lam deposit, $12 \mathrm{~km}$ north-northeast of Thiès, and a small occurrence near Popenguine, south-southwest of Thiès (Brückner, 1957, p. 248-250). Aluminum phosphate is now mined at Pallo by the Société Sénégalaise des Phosphates de Thiès (SSPT), a company jointly owned by Pechiney and the Senegal Government (Mining Annual Review, 1988). The deposits contain aluminum phosphate, calcium aluminum phosphate, and tricalcium phosphate. Information on the relative abundance of the three types is not available. Deposits are of middle Eocene to Oligocene age and contain the phosphate minerals carbonate-fluorapatite, crandallite, millisite, and wavellite (Capdecomme, 1953; Flicoteaux and others, 1977). The phosphate in the Thiès region, like that in Florida, contains uranium (Capdecomme and Pulou, 1954; Latrilhe, 1959, p. 81). Reserves of aluminum phosphate rock in the Pallo deposit are estimated to be 100 million metric tons (Mining Annual Review, 1988). The Thiès region is the only place in the world where significant tonnages of aluminum phosphate are mined. The Mining Annual Review (1988) reported that the 1985 production of aluminum phosphate, used for fertilizer, was 355,300 metric tons.

Aluminous phosphate rocks in the Taïba district, north of the Thiès region, are reported to consist chiefly of 
WORLD NONBAUXITE ALUMINUM RESOURCES EXCLUDING ALUNITE

TABLE 11.-Chemical analyses (in weight percent) of seven samples from the aluminum phosphate zone in the Bone Valley Formation, Florida [From Altschuler and others (1956, p. 501). Analyst: F. Cuttitta, U.S. Geological Survey]

\begin{tabular}{|c|c|c|c|c|c|c|c|}
\hline & Ho-20 & Ho-20A & Ho-21 & Ho-22 & $\mathrm{Ho}-23$ & Ho-24 & Ho-25 \\
\hline $\mathrm{SiO}_{2} \ldots \ldots \ldots \ldots \ldots \ldots \ldots$ & 51.48 & 62.60 & 40.92 & 57.24 & 69.46 & 68.08 & 51.32 \\
\hline $\mathrm{Al}_{2} \mathrm{O}_{3} \ldots \ldots \ldots \ldots \ldots \ldots$ & 8.26 & 5.98 & 12.48 & 14.17 & 8.16 & 9.40 & 14.91 \\
\hline $\mathrm{Fe}_{2} \mathrm{O}_{3}{ }^{\mathrm{a}} \ldots \ldots \ldots \ldots \ldots \ldots$ & 2.76 & 2.86 & 2.61 & 2.17 & 1.32 & 1.33 & 2.19 \\
\hline $\operatorname{MnO} \ldots \ldots \ldots \ldots \ldots \ldots \ldots$ & .70 & .53 & 2.14 & .16 & .16 & .14 & .13 \\
\hline$\ldots \ldots, \ldots, \ldots, \ldots, \ldots$ & .01 & .01 & .01 & .01 & .01 & .01 & .01 \\
\hline n.w. & 8.98 & 8.25 & 8.00 & 3.10 & .90 & .20 & 1.20 \\
\hline $\mathrm{Na}_{2} \mathrm{O}$ & .23 & .13 & .12 & .15 & .06 & .04 & .03 \\
\hline $\mathrm{K}_{2} \mathrm{O} \ldots \ldots \cdots \cdots \cdots \cdots \cdots \cdots$ & .00 & .00 & .00 & .00 & .00 & .00 & .00 \\
\hline$\ldots \ldots, \cdots, \cdots, \cdots$, & .37 & .40 & .63 & .63 & .31 & .42 & .65 \\
\hline$\ldots, \cdots, \cdots, \cdots, \cdots$, & 19.72 & 13.60 & 20.79 & 12.79 & 11.61 & 11.32 & 16.35 \\
\hline $\mathrm{LOI}^{\mathrm{b}} \ldots \ldots \ldots \ldots \ldots \ldots \ldots$ & 6.76 & 6.09 & 11.72 & 9.96 & 7.91 & 9.18 & 13.24 \\
\hline $\mathrm{CO}_{2} \ldots \ldots \ldots \ldots \ldots \ldots \ldots$ & .80 & .24 & .26 & .05 & .02 & .02 & .05 \\
\hline$\ldots \ldots \ldots \ldots \ldots \ldots \ldots$ & 1.15 & .52 & .63 & .59 & .51 & .70 & .53 \\
\hline Cl.. . & .03 & .02 & .04 & .01 & .03 & .02 & .01 \\
\hline $\mathrm{SO}_{3}{ }^{\mathrm{c}} \ldots \ldots \ldots \ldots \ldots \ldots \ldots \ldots$ & .01 & .01 & .01 & .01 & .01 & .01 & .01 \\
\hline $\mathrm{Cr}_{2} \mathrm{O}_{3} \ldots \ldots \cdots \cdots \cdots \cdots \cdots \cdots$ & .01 & .01 & .01 & .01 & .01 & .01 & .01 \\
\hline $\mathrm{V}_{2} \mathrm{O}_{5} \ldots \ldots \ldots \ldots \ldots \ldots \ldots \ldots$ & .00 & .00 & .00 & .00 & .00 & .00 & .00 \\
\hline $\mathrm{U}^{\mathrm{d}} \ldots \ldots \ldots \ldots \ldots \ldots \ldots \ldots \ldots$ & .01 & .03 & .02 & .01 & .01 & .01 & .01 \\
\hline Total $\ldots \ldots \ldots \ldots \ldots \ldots \ldots$ & 101.28 & 101.28 & 100.39 & 101.06 & 100.49 & 100.89 & 100.65 \\
\hline
\end{tabular}

${ }^{2} \mathrm{Fe}_{2} \mathrm{O}_{3}$ represents total iron, some of which may be present as ferrous iron.

${ }^{b}$ The figures for loss on ignition (LOI) include adsorbed water $\left(\mathrm{H}_{2} \mathrm{O}^{-}\right)$and exclude $\mathrm{CO}_{2}$.

${ }^{c} \mathrm{SO}_{3}$ represents total sulfur; no sulfides were found.

${ }^{\mathrm{d}}$ Uranium is reported as a metal, as its valence state was not determined.

crandallite and to contain 25-32 percent $\mathrm{Al}_{2} \mathrm{O}_{3}$ (Slansky and others, 1964).

\section{OTHER COUNTRIES}

Aluminous phosphate rocks occur in several countries other than the United States and Senegal, which have the largest known resources. Deposits of phosphatic bauxite on Trauira Island in the delta of the Maracassumé River, Maranhão, Brazil, are reported to contain 10 million metric tons of rock (Brazil Divisão de Fomento da Produção Mineral, 1943, p. 26-27) having 31 percent $\mathrm{Ai}_{2} \mathrm{O}_{3}$ and 30 percent $\mathrm{P}_{2} \mathrm{O}_{5}$ (Paiva and others, 1937, p. 147). Another deposit, at Pircãua near the coast in northeastern Maranhão, is reported to contain 10 million metric tons that are 40 percent $\mathrm{Al}_{2} \mathrm{O}_{3}$ (Harrington and others, 1966, p. 35). An aluminous phosphate layer is present locally between the bauxite and the underlying limestone in Jamaica (Eyles, 1958, p. 1367). Deposits of aluminous phosphate rock having some economic potential occur in the Los Islands, Guinea, and near Abeokuta, Nigeria (Russ, 1924; Arnaud, 1945, p. 85-86). The deposits in Nigeria contain 25-29.7 percent $\mathrm{Al}_{2} \mathrm{O}_{3}$ and 26.3-33 percent $\mathrm{P}_{2} \mathrm{O}_{5}$ (Russ, 1924). Aluminous phosphate rocks are present in the Saldanha Bay area, South Africa (Visser and Schoch, 1973). Aluminous phosphate rock on North Daitō Island, Japan, which contains 23-30 percent $\mathrm{Al}_{2} \mathrm{O}_{3}$, was investigated as a source of aluminum during World War II (Sato and others, 1956, p. 197). Resources of aluminous phosphate rock in this area and elsewhere in
Japan are too small to be considered a viable source of aluminum in peacetime. Aluminous phosphate rock occurs in association with bauxite in Jurassic rocks in the northern Urals, U.S.S.R. (Bushinsky and Bogolyubova, 1960 ), and crandallite occurs in supergene phosphate deposits in the Karatau basin (Zanin and others, 1977).

\section{SAPROLITE}

"Saprolite," a term introduced by Becker (1895, p. $289)$, means rotten rock. Saprolite is an earthy, decomposed product of the subaerial chemical weathering of any kind of rock in place (Overstreet, 1961, p. 447). Textural, structural, planar, and linear features of the original rock are preserved in saprolite. The term "saprolite" has about the same meaning as the British term "lithomarge." However, Tardy and Nahon (1985, p. 869-871) suggested that the name "saprolite" be applied to weathered rock containing some of the unweathered minerals of the parent rock, whereas lithomarge refers to weathered rock in which all the original parent rock minerals have been replaced or destroyed.

The principal aluminous minerals in saprolite include kaolinite (39.5 percent $\mathrm{Al}_{2} \mathrm{O}_{3}, 46.5$ percent $\mathrm{SiO}_{2}$, and 14.0 percent $\mathrm{H}_{2} \mathrm{O}$ ), halloysite (34.7 percent $\mathrm{Al}_{2} \mathrm{O}_{3}, 40.8$ percent $\mathrm{SiO}_{2}$, and 24.5 percent $\mathrm{H}_{2} \mathrm{O}$ ), and gibbsite (65.4 percent $\mathrm{Al}_{2} \mathrm{O}_{3}, 34.6$ percent $\mathrm{H}_{2} \mathrm{O}$ ). Generally, saprolite that is a potential resource of alumina contains $20-38$ percent $\mathrm{Al}_{2} \mathrm{O}_{3}$. 


\section{UNITED STATES}

Saprolite in the United States occurs in the Piedmont region of the Southeastern States, is associated with the bauxite deposits of Arkansas, is present in Oklahoma, and is developed on basalt in the Northwestern States (Oregon, Washington, and Idaho) and Hawaii. Although these areas of saprolite contain large amounts of alumina resources and although considerable research has been devoted to the extraction of alumina from saprolite, producing aluminum from saprolite is currently too costly.

\section{Southeastern United States}

In the Piedmont region of the Southeastern States, saprolite was investigated by major aluminum companies in 1957 (Chemical Week, 1957). Piedmont Properties, affiliated with Alcoa, obtained an option on 10,000 ha in the Spartanburg-Rutherfordton region, North Carolina and South Carolina. Palmetto Lands Company acquired land for Kaiser Aluminum in the same region. Gibbsite Corporation of America, a subsidiary of Colonial Oil and Gas Corporation, patented a process for separating gibbsite, $\mathrm{Al}_{2} \mathrm{O}_{3} \cdot \mathrm{H}_{2} \mathrm{O}$, from saprolite for use in aluminum production and obtained options on thousands of hectares of land in northwestern North Carolina and southwestern Virginia (Engineering and Mining Journal, 1970). Environmentalists in North Carolina opposed this effort, and two newspapers in Winston-Salem won a 1971 Pulitzer Prize in recognition of their successful efforts to prevent strip mining of saprolite in North Carolina (Winston-Salem Journal, 1971). After a period of inactivity, the Gibbsite Corporation of America leased 4,047 ha of gibbsite-bearing land near Galax, Va., and announced plans to construct a plant (American Metal Market, 1981). The plant was not built, and it is unlikely that one will ever be built because of a Final Judgment of Permanent Injunction by Consent that was filed in February 1982 (United States Court, Western District of New York, 1982, Civ.-82-0018B(C)).

The saprolite examined by the companies in the Spartanburg-Rutherfordton region, North Carolina and South Carolina, formed on sillimanite and biotite schists and igneous rocks (Overstreet and Griffitts, 1955). Councill and Llewellyn (1959) summarized the results of chemical analyses of 90 samples of saprolite, mostly from a large area in South Carolina south and east of the area investigated by the aluminum companies. These samples are from saprolite developed on various types of mica schist, rocks of the slate belt, granite, pegmatite, sillimanite schist, and hornblende-bearing rocks. The analyses indicate 2-16 percent free $\mathrm{Al}_{2} \mathrm{O}_{3}$ in gibbsite, 2-11 percent $\mathrm{Fe}_{2} \mathrm{O}_{3}$, and 8-26 percent total $\mathrm{Al}_{2} \mathrm{O}_{3}$.
As part of a reconnaissance investigation, the authors collected 12 samples of saprolite in the vicinity of Shelby, N.C., and northwest of Gaffney, S.C. Both areas are in the belt investigated by aluminum companies. These samples were analyzed by $\mathrm{X}$-ray fluorescence and were found to contain 25-36 percent $\mathrm{Al}_{2} \mathrm{O}_{3}$. Some of these samples contained more gibbsite than required to account for the small amount of free alumina reported by Councill and Llewellyn (1959). In addition to gibbsite, the saprolite contains halloysite, altered mica, quartz, and iron-bearing minerals. Most of the gibbsite is very fine grained and intimately mixed with clay minerals so that it is extremely difficult to make a gibbsite concentrate. The saprolite in the region where these samples were collected also contains minor quantities of monazite, zircon, ilmenite, sillimanite, rutile, and garnet (Overstreet and others, 1963). No information is available on the total size of these deposits, but they are known to extend irregularly over many tens of square kilometers, and if the average thickness is only a few meters, they contain many hundreds of millions of metric. tons of aluminous rock.

Saprolite occurs on many types of sedimentary, metamorphic, and igneous rocks in the Piedmont from southcentral Pennsylvania in the north to north-central Alabama in the south. Alexander and others (1942) recognized gibbsite in soils developed on saprolite derived from the following types of bedrock: (1) amphibolite in Hall County, Ga., and Rutherford County, N.C.; (2) norite in Mecklenburg and Rowan Counties, N.C.; (3) epidote-bearing greenstone schist in Chatham County, N.C.; (4) diabase in Fauquier County, Va.; and (5) biotite-muscovite schist in Hall County, Ga., and Pickens County, S.C. The gibbsite contents in whole-soil samples collected from above the five rock types were low, but in the clay-sized fraction, the gibbsite content was as high as 33 percent.

Other investigations of gibbsite in saprolite and soil in the Southeastern United States include those of (1) Bryant and Dixon (1964), who studied the soil from the Alabama Piedmont area; (2) Clarke (1963), who worked on several types of residual materials from the Alabama Piedmont; (3) Cady (1951), who described saprolite formed from diorite in Rowan County, N.C.; (4) Calvert and others (1980), who studied saprolite in a quarry at Raleigh, N.C.; (5) Cate and McCracken (1972), who found gibbsite in both soil and saprolite of a micahornblende gneiss and a mica gneiss in Caldwell and Rutherford Counties, N.C.; and (6) McCracken and others (1971) and Losche and others (1970), who discussed gibbsite in surficial materials in the southern Piedmont and Appalachian basin.

Saprolite in Coosa County, Ala., and at Ennice in Alleghany County, N.C., was investigated as a possible 
substitute for refractory-grade bauxite (White, 1984). Additional investigations of gibbsite in saprolite in eastcentral Alabama were conducted by Beg $(1982,1984)$. Saprolite formed from feldspathic hornblende gneiss in three areas in Chambers County, Ala., contains 915,225 metric tons of gibbsite (Beg, 1984, table 4). The gibbsite content in the saprolite ranges from 10.0 to 19.25 percent.

Extensive titaniferous aluminous saprolite in the weathered parts of the Roseland Anorthosite in Nelson and Amherst Counties, Va., is a potential important source for both alumina and titania $\left(\mathrm{TiO}_{2}\right)$. Rutile $\left(\mathrm{TiO}_{2}\right)$ and ilmenite $\left(\mathrm{Fe}^{2+} \mathrm{TiO}_{3}\right)$ have been recovered from this saprolite. The inferred reserves of saprolite exceed 20 million metric tons and contain an average of 7 percent $\mathrm{TiO}_{2}$ (Fish, 1962, p. 38). No information on the alumina content of saprolite in this area has been published, but part of the saprolite contains considerable kaolin and, therefore, is rich in alumina.

\section{Arkansas}

The saprolite associated with the bauxite in Arkansas has not been adequately investigated, and little is known of its extent or quality. However, information presented by Gordon and others (1958, p. 255) indicates that reserves of kaolin in saprolite are probably large enough to supply a large alumina plant. Two samples of kaolinbearing saprolite derived from the nepheline syenite underlie the bauxitic clay and contain 37.2-39.6 percent $\mathrm{Al}_{2} \mathrm{O}_{3}$ and $42.9-44.0$ percent $\mathrm{SiO}_{2} ; 13.5-14.4$ percent of the samples was lost on ignition (Gordon and others, 1958, table 10, samples 15 and 16).

\section{OKLAHOMA}

Large deposits of clay and underlying saprolite occur on the anorthosite and other igneous rocks in Kiowa County, Okla. Knox (1948, p. 4) described this saprolite as having formed by the decomposition of anorthosite and gabbro in place. An analysis of a composite sample of saprolite from this area (Knox, 1948, p. 17) shows 21.89 percent $\mathrm{Al}_{2} \mathrm{O}_{3}$, whereas the clay above the saprolite contains 26.34 percent $\mathrm{Al}_{2} \mathrm{O}_{3}$. The low alumina content of these rocks limits their potential as a source of aluminum.

\section{NORThWESTERN UNited STATES}

Deposits of aluminous saprolite and associated ferruginous bauxite are on weathered basalt in Oregon and Washington. The saprolite underlies the bauxite and varies considerably in thickness. According to Allen (1952, fig. 2), one drill hole in Oregon showed $34 \mathrm{~m}$ of basalt saprolite overlain by approximately $14 \mathrm{~m}$ of baux- ite. Valentine and Huntting (1960, p. 16) reported that bauxite in Washington is as much as $6 \mathrm{~m}$ thick and is underlain by $6 \mathrm{~m}$ or more of basalt saprolite. According to chemical analyses, much of this saprolite contains 25-30 percent $\mathrm{Al}_{2} \mathrm{O}_{3}, 25-35$ percent $\mathrm{Fe}_{2} \mathrm{O}_{3}$, and 5-7 percent $\mathrm{TiO}_{2}$. This saprolite consists chiefly of halloysite and iron oxide minerals and contains minor amounts of gibbsite, ilmenite, and titaniferous magnetite.

In eastern Washington and northern Idaho, two types of aluminous saprolite (called high-alumina clay by some researchers) occur-(1) saprolite derived from the Columbia River Basalt Group of Miocene age and (?) saprolite derived from granodiorite and related intrusi ' $\mathrm{e}$ rocks of the Idaho batholith of Late Jurassic or Cret $x-$ ceous age. The basalt saprolite is composed of white halloysite, which is commonly colored blue or gray y ilmenite and which, in places, is stained brown iy limonite or green by nontronite. The granodiorite saprolite consists predominantly of kaolinite and quartz (Ho:terman and others, 1960). Table 12 summarizes the range in chemical composition for 41 granodiorite saprolite samples and 59 basalt saprolite samples. The thickness of the granodiorite saprolite is reported to be at least $30 \mathrm{~m}$ (Wilson and Goodspeed, 1934, p. 8). According to Scheid (1946), there are 11.3 million metric tons of saprolite in Spokane County, Wash. Scheid and Sohn (1946) reporte : 9.8 million metric tons of transported clay and saprolit: in Latah County, Idaho; 40 percent of this estimater? resource is saprolite. Several of the saprolite deposits in Latah County have been mined for use as a paper filler.

TABLE 12.-Chemical composition ranges of saprolite from Spokane County, Washington

[Modified from Hosterman (1969a, tables 1, 3, 19). LOI, loss on ignition]

\begin{tabular}{|c|c|c|}
\hline & $\begin{array}{l}\text { Granodiorite saprolite } \\
\text { (41 samples) }\end{array}$ & $\begin{array}{l}\text { Basalt saprolite } \\
\text { (59 samples) }\end{array}$ \\
\hline 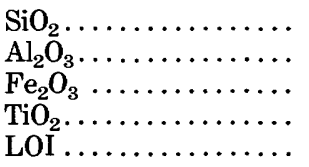 & $\begin{array}{l}48-73 \\
15-29 \\
0.4-12.7 \\
0.1-2.0 \\
1.5-11.1\end{array}$ & $\begin{array}{l}26-70 \\
14-38 \\
0.4-24 \\
0.8-9.7 \\
7.2-14.6\end{array}$ \\
\hline
\end{tabular}

HaWAII

Large deposits of aluminous saprolite are associated with low-grade bauxite on the islands of Kauai and Maui, Hawaii. The saprolite occurs below the bauxite as well as in many areas where bauxite is absent. This saprolite consists chiefly of fine-grained mixtures of halloysite, gibbsite, and iron- and titanium-bearing minerals. The deposits on Kauai have weathered from olivine basalt and feldspathoid-rich rocks; those in eastern Maui are from olivine basalt, and those in western Maui are from andesite and soda trachytes. The potential resource of aluminous saprolite on Kauai is estimated to be 500 
milion metric tons (Patterson, 1971, p. 1, 42). This saprolite contains approximately 20 percent $\mathrm{SiO}_{2}, 27$ percent $\mathrm{Al}_{2} \mathrm{O}_{3}, 27$ percent $\mathrm{Fe}_{2} \mathrm{O}_{3}$, and 5 percent $\mathrm{TiO}_{2}$. At least 200 million metric tons of gibbsitic and halloysitic saprolite in western Maui contain approximately 20 percent $\mathrm{SiO}_{2}, 33$ percent $\mathrm{Al}_{2} \mathrm{O}_{3}, 22$ percent $\mathrm{Fe}_{2} \mathrm{O}_{3}$, and 4 pei sent $\mathrm{TiO}_{2}$ (Patterson, 1971, p. 66). More than 200 mil ion metric tons of gibbsitic and halloysitic saprolite in eas sern Maui contain about 15 percent $\mathrm{SiO}_{2}, 31$ percent $\mathrm{Al}_{2} \mathrm{O}_{3}, 27$ percent $\mathrm{Fe}_{2} \mathrm{O}_{3}$, and 6 percent $\mathrm{TiO}_{2}$ (Patterson, 1971, p. 66).

\section{OTHER COUNTRIES}

Yery extensive deposits of aluminous saprolite underlie most major bauxite areas of the world except those that are associated with limestone. Extensive saprolite deposits occur in tropical areas where bauxite is absent (Tardy, 1969), and many deposits underlie the widespread ferruginous laterites (Sivarajasingham and others, 1962, p. 24-39). The world's aluminous saprolite derosits are probably many times larger than the total bal xite deposits. There is no information in the literature to indicate that aluminous saprolite deposits outside the United States have been considered as possible sources of aluminum.

\section{ALUMINOUS METAMORPHIC ROCKS}

sluminous metamorphic rocks contain kyanite and related minerals, known as the kyanite- or sillimanitegrc up minerals; these high-alumina minerals are used in the manufacture of refractory materials and a few other prc ducts. The three most common members of the group are kyanite, sillimanite, and andalusite, all of which have the chemical composition $\mathrm{Al}_{2} \mathrm{O}_{3} \cdot \mathrm{SiO}_{2}\left(63.2\right.$ percent $\mathrm{Al}_{2} \mathrm{O}_{3}$ anc 36.8 percent $\mathrm{SiO}_{2}$ ). Topaz is also a member, and durnortierite is related to this group (table 13) in composition and thermal behavior. All five minerals convert to mullite $\left(3 \mathrm{Al}_{2} \mathrm{O}_{3} \cdot \mathrm{SiO}_{2}\right)$ and free silica, usually cristobalite, at ¿bout $1,200-1,600{ }^{\circ} \mathrm{C}$ (Foster, 1960). Natural mullite is very rare, but large amounts of synthetic mullite are used for refractory purposes and ceramic products.

Kyanite-group minerals occur chiefly in metamorphic rocks such as schists and gneisses, but they also occur in quartz veins and pegmatites. They are locally abundant in placer deposits. Kyanite is the principal mineral of the group that is mined.

As described by Espenshade (1973), the kyanite-group minerals are very common in many parts of the world in aluminous metamorphic rocks that have recrystallized at elevated temperatures. Each mineral in this group forms at certain distinctive temperature and pressure conditions (Bell, 1963). Kyanite forms in schists and gneisses at fairly high temperatures and pressures under conditions of strong metamorphism. Andalusite forms at lower pressures and is common in contact metamorphic zones of large intrusions of granite or gabbro. Sillimanite forms during both regional and contact metamorphism and indicates higher temperatures than does andalusite. Topaz and dumortierite, which are much less common than the other three minerals, are most abundant in quartz-rich rocks such as granite and gneiss and in hydrothermally altered volcanic rocks. Metamorphic rocks may contain as much as 40 percent kyanite-group minerals, but generally the content of these minerals is less than 15 percent (Espenshade, 1973, p. 309). Ordinarily, only one of the kyanite-group minerals is present, but two of them do occur together in some deposits, and kyanite, andalusite, and sillimanite have been found together in a few deposits.

The United States is the world's leading producer of kyanite, and kyanite is the only mineral of its group being mined on a commercial scale in the country. Brazil has the potential to become a major kyanite producer; its kyanite reserves are at least 3 million metric tons (Potter, 1985, p. 427). India has been a major kyanite producer but has restricted exports to conserve limited reserves of high-grade residual lumps of kyanite (Potter, 1985 , p. 426, 428). Significant kyanite deposits are also present in Australia, Austria, Bulgaria, Canada, Fin-

TABLE 13.-Characteristics of the kyanite-group minerals

[From Ford (1921, p. 612-617, 637)]

\begin{tabular}{|c|c|c|c|c|c|}
\hline \multirow{2}{*}{ Mineral } & \multicolumn{2}{|c|}{ Theoretical content ${ }^{1}$} & \multirow{2}{*}{ Specific gravity } & \multirow{2}{*}{ Hardness } & \multirow{2}{*}{ Crystal system } \\
\hline & $\mathrm{Al}_{2} \mathrm{O}_{3}$ & $\mathrm{SiO}_{2}$ & & & \\
\hline Ky: nite............ & 63.2 & 36.8 & $3.56-3.67$ & $5-7.25$ & Triclinic. \\
\hline Anc alusite $\ldots \ldots \ldots \ldots$ & 63.2 & 36.8 & $3.16-3.20$ & 7.5 & Orthorhombic. \\
\hline Sill:manite. & 63.2 & 36.8 & $3.23-3.24$ & $6-7$ & Orthorhombic. \\
\hline Dui ortierite $^{2}$ & 64.5 & 28.5 & $3.26-3.36$ & 7 & Orthorhombic. \\
\hline Top $z^{3} \ldots \ldots \ldots \ldots \ldots \ldots \ldots \ldots \ldots$ & 55.4 & 32.6 & $3.4-3.6$ & 8 & Orthorhombic. \\
\hline Mulite......................... & 72.8 & 27.2 & 3.23 & $6-7$ & Orthorhombic. \\
\hline
\end{tabular}


land, Kenya, Liberia, Namibia, Norway, South Africa, Spain, Sweden, the U.S.S.R., and Zimbabwe.

South Africa is the world's leading producer of andalusite, and its reserves of andalusite and sillimanite are about 105 million metric tons (Potter, 1985, p. 427). Sillimanite deposits are also present in Australia, India, and the U.S.S.R. Andalusite deposits are also present in France, Spain, and Swaziland.

Nearly all of the kyanite-group minerals that have been mined were prepared for use as refractory materials, and the iron and steel industry was the principal consumer (Radcliffe, 1976). Minor uses of kyanite include blown alumina silicate, high-temperature insulation, brake linings, foundry mold facings, pyrometer tubes, electric porcelain insulators, spark plug insulators, mortars, grinding media, and welding rod coating (Potter, 1980). The extraction of alumina from kyanite-group minerals has been investigated by Sweden and the U.S.S.R. This research is discussed in the "Alumina Extraction Research" section.

\section{UNITED STATES}

The kyanite-group minerals occur in almost every large area of metamorphic rocks in the United States (Espenshade and Potter, 1960; Espenshade, 1961, 1962, 1973). Members of this group have been found in at least 30 States, as documented in a bibliography by Grametbaur (1959). Many of the known occurrences of these minerals are in deposits that are too small or too impure to be classified as resources (Espenshade, 1973). Only those deposits containing at least 10 percent kyanitegroup minerals are of potential value. Total identified and hypothetical resources of kyanite-group minerals in the United States were estimated by Espenshade (1973, table 62) to be a little more than 2 billion metric tons. According to Industrial Minerals (1985, p. 50), the identified resources of kyanite in the United States are 30 million metric tons, which represent 28 percent of the world's total.

Most kyanite-group minerals in the United States occur in micaceous schist and gneiss, but 95 percent of the U.S. production of these minerals has come from quartzose deposits, such as quartzite and quartz-rich igneous rock, which contain no more than 5 percent of the total U.S. resource (Espenshade, 1973, p. 309). Most of the domestic production of kyanite has come from large quartzose deposits in the Southeastern States. Similar, though much smaller, deposits have been mined in the Western States. Quartzose deposits in the Western States include kyanite in Imperial County, Calif. (Wright, 1957), andalusite at White Mountain, Mono County, Calif. (Kerr, 1932), and dumortierite and andalusite near Oreana, Nev. (Kerr and Jenney, 1935).
The most recently active mines in the Southeast are the Wills Mountain and East Ridge mines in Buckingham County, Va., which have been operated since 1922 and which are the only active U.S. mines today; the Henry Knob mine in York County, S.C., which was operated from 1948 through 1969; and the Graves Mountain mine in Lincoln County, Ga., which was operated from 1963 to September 1986 (Potter, 1980, 1988).

Minor kyanite and sillimanite deposits in schists and gneisses are widely distributed in the Appalachian region from Maine to Alabama. The principal deposits are near New Hartford, Conn. (Espenshade, 1973), near Spruce Pine, N.C. (Brobst, 1962), in central Maine (Espenshade and Boudette, 1967), and in Hart County, Ga. (Teague, 1950). Kyanite-group minerals are also widely distributed in schists and gneisses in Montana (Groff, 1963), Washington (Thorsen, 1966), Oregon (Espenshade, 1973), the Black Hills, S.D. (Redden and Norton, 1975), the Sierra Nevada Mountains, Calif. (Wright, 1957), and the east-central Front Range, Colo. (Marsh and Sheridan, 1976). The largest known deposits in the Western States that are sufficiently large and rich to be considered a major resource are the kyanite-sillimanite deposits at Woodrat Mountain, Idaho (Hietanen, 1956; Van Noy and others, 1970). These deposits contain an estimated 5.1 billion metric tons of micaceous gneiss that is 15 percent kyanite and sillimanite (Van Noy and others, 1970, table 7).

Minor quantities of kyanite-group minerals occur in clastic sedimentary rocks in the Coastal Plains bordering the Atlantic Ocean and the Gulf of Mexico. Kyanite and sillimanite occur in small amounts in beach sands of Florida, Georgia, and New Jersey (Browning and others, 1956; Espenshade, 1973, p. 310). Potter reported (1985, p. 425,426$)$ that kyanite and sillimanite were recovered from Pleistocene beach sands in Florida from 1968 to 1973 , and he estimated (1985, p. 432) that an additional 10 million metric tons of kyanite and sillimanite could be recovered from the Florida beach sands as a coproduct with zircon and titanium-bearing minerals.

Small amounts of kyanite-group minerals and other heavy minerals are present in Florida in the phosphate rock. Stow (1968) estimated that about 200,000 metric tons of heavy minerals containing about 16 percent kyanite and sillimanite are discarded yearly from the Florida phosphate mining operations.

\section{CANADA}

The Canadian Department of Mines and Technical Surveys described kyanite deposits in Ontario and British Columbia (Haw, 1954), and its successor, the Canadian Centre for Mineral and Energy Technology (CANMET), investigated kyanite deposits as a possible 
alumina resource (Collings and Brown, 1976). The kyanite at Mattawa, Ontario, occurs as disseminated crystals in a gneiss, and of two samples analyzed, the higher grade was only 14.6 percent kyanite (Haw, 1954, p. 29). The kyanite in the Sudbury district, Ontario, occurs as coarse blades making up 15-30 percent of a kyanitegarnet-biotite-quartz-feldspar gneiss (Haw, 1954). According to Industrial Minerals (1985, p. 50), the identified resources of kyanite in Canada are 45 million metric tons, which represent 42 percent of the world's total.

\section{FINLAND, SWEDEN, AND NORWAY}

Metamorphic rocks containing sillimanite, kyanite, and andalusite are found at various places in Finland (Shaikh, 1977, p. 195; Sotka and Soderholm, 1980). According to Industrial Minerals (1985, p. 50), the identified resources of kyanite in Finland are 300,000 metric tons. Deposits of kyanite-group minerals were listed by Sha:kh (1977, p. 195). In 1977, kyanite in a sericite schist in tie Hallavaara area was investigated. Some zones cont ain 16-21 percent kyanite. A deposit at Mantovaara, min $a$ for use in a cement plant, contains as much as 30 percent andalusite. Other denosits at Tohmajärvi and Hat wa contain 10-15 percent andalusite. Deposits containi... 3 percent sillimanite are at Kursukyllä and Pahar.m.

Nam sumanite, andalusite, and lyanite deposits occur in Sveden; the largest is ? hyanite doposit at Halisjovergê, Vamiand (Slaikh, 1977, p. 195). This deposit, which consists of kyanite-bearing micaceous quartitie, has a known reserve of 22 million metric tons and a pentiat esoure of an additional 25 million metric tons. ilar assits containing 5-30 areent kyanite also occur in Norway (Shaikh, i27\%, p. 195 ,

\section{INDIA}

Kyanite-group minerals are distributed widely in India, and India was formerly among the world's leading producers and exporters of kyanite-group minerals (Varley, 1965). According to a market survey (Indian Bureau of Nines, 1975 ; is 1975 India had reserves of 20.2 million metric tons of ryanite in quartzose rocks and 132 milion metric tons of sililmanite in Eeach sands. The Incian government now sererely restuicts be export of xeractory mine."a's, and production is now small ifotter, 3982, 1985: The rancipal kyanite distrints of Trdia are in Bihar, an most sillimanite denosite are $\cdots$ " Bengal and $A, s \sin ^{2}$.

Varle $1965.62-70)$ sescriber the most important kyanite depostis of Sinar. These de osits are in the

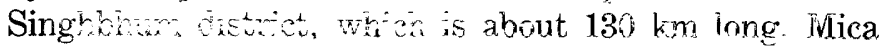

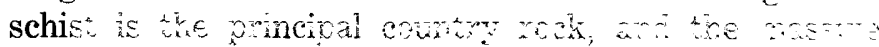

kyanite is associated with quartz-kyanite rock or granulite. The most productive deposits in this district were at Lapsa Buru, where the best grade material was found in massive boulders. The kyanite is in medium to large crystals, many of which are radiating. India's identified resources of kyanite are more than 3.8 million metric tons (Industrial Minerals, 1985, p. 50).

The principal sillimanite deposits in West Bengal are in the Purulia district (Varley, 1965, p. 79; Potter, 1982) and consist of heavy-mineral sand deposits having an average thickness of about $1.2 \mathrm{~m}$. The sillimanite content of the sand is $0.80-1.00$ percent, and the sand contains similar percentages of ilmenite and monazite and lesser amounts of zircon, rutile, and other heavy minerals.

The principal sillimanite deposits in Assam are on the Khasi Hills plateau, and these deposits have been the source of most of India's production (Varley, 1965, p. 68). The typical deposit consists of boulders, weighing as much as 100 metric tons each and containing massive sillimanite and a little corundum. Some boulders are almost wholly corundum, and several have been found that are wholly sillimanite. A typical boulder of commercial interest from this area averages 61 percent $\mathrm{Al}_{2} \mathrm{O}_{3}(58$ percent minimum), averages 1.0 percent $\mathrm{Fe}_{2} \mathrm{O}_{3}$ (1.8 percent maximum), and has a maximum loss on ignition of 2.0 percent.

Sillimanite-bearing beach sand occurs in many places and is most abundant in the States of Kerala and Madras in southernmost India (Varley, 1965, p. 73-74). It varies considerably in composition from place to place but generally consists of 75-95 percent heavy minerals. This beach sand is estimated to contain 12 million-14 million metric tons of sillimanite (Varley, 1965, p. 66).

\section{SOUTH AFRICA}

Kyanite-group minerals are widely distributed in South Africa, and this country is the world's leading producer of andalusite (Potter, 1985, p. 425). South Africa's reserves of andalusite and sillimanite are about 105 million metric tons (Potter, 1985, p. 427). In 1365, kyanite had not been found in economic quantities iVarley, 1965, p. 96), but in 1985, Industrial Minerals $(1985$, p. 50) estimatea the identified kyanite resources to pe 12 million metric tons, which had not been mined commercially.

ilost of the andalusite production comes from andalusite-bearing shales and alluvial deposits in the Transvaal region (Industrial Minerals, 1985, p. 41). The alluvial deposits contain andalusite eroded from shales of the Pretoria Group in the contact metamorphic zone surrounding the Bushveld Complex (Varley, 1965, p. 97). Anjelusite, liberated from the parent rock by weather- 
ing, was transported by flood waters to a more level terrain where it was upgraded by strong winds that removed the fine-grained, light-weight material. The alluvial deposits contain 10-50 percent andalusite with 53-58 percent alumina, and the shale contains 7-15 percent andalusite with 52-60 percent alumina (Industrial Minerals, 1985, table 2). In 1965, reserves of material containing at least 50 percent andalusite were conservatively estimated to be 800,000 metric tons in the Marico district, Transvaal (Varley, 1965, p. 97). According to a review by Brabers (1974, p. 12-13) of the potential aluminum resources of South Africa, some of the very large resources of andalusite in the contact metamorphic zone surrounding the Bushveld Complex are associated with staurolite, which contains about 16 percent iron oxide that would make alumina extraction difficult. Industrial Minerals (1985, table 2) estimated that the Transvaal region contains 50.5 million metric tons of andalusite reserves and 106.5 million metric tons of resources.

Irregular lenticular bodies of corundum-sillimanite rocks have been mined in the Namaqualand region in the northwestern part of the Cape of Good Hope Province (Varley, 1965). The sillimanite reserves of this area were estimated by Jager (1963) to be only 126,000 metric tons, an amount that would last only a few years at the 1963 rate of mining. Jager further estimated that the region contained 3 million metric tons of low-grade sillimanite rock containing 568,000-955,000 metric tons of sillimanite. Sillimanite production in South Africa has been steadily decreasing because the high-grade deposits have been depleted (Industrial Minerals, 1985, p. 45).

\section{U.S.S.R.}

The largest reserves of kyanite in the U.S.S.R. (and in the world) are in the elongated Keiv district in the central part of the Kola Peninsula (Kirpal' and Tenyakov, 1974, p. 320-322). A rich kyanite schist in this district ranges from 80 to $150 \mathrm{~m}$ in thickness and extends for 140 $\mathrm{km}$. Three grades of kyanite schist are recognized: (1) rich ores containing more than 40 percent kyanite, (2) medium-grade ores containing 30-40 percent kyanite, and (3) lean ores containing less than 20 percent kyanite.

Several deposits of kyanite and sillimanite in Siberia have been investigated as possible sources of alumina (Galaburda, 1958; Mikhaylov and others, 1977). Sillimanite deposits near Kyakhta, near the Mongolian border south of Lake Baykal, are among the most important deposits in the U.S.S.R. (Varley, 1965). Concentrates from these deposits are reported to contain 53.44 percent $\mathrm{Al}_{2} \mathrm{O}_{3}$ and 39.62 percent $\mathrm{SiO}_{2}$ (Varley, 1965, p. 92). Kyanite-group minerals also occur in the eastern Sayan Mountains west of Lake Baykal, in at least two areas north of Lake Baykal, and in several areas along the southern and western margins of the Aldan Shield in eastern Siberia. The identified resources of kyanite in the U.S.S.R. are 3.5 million metric tons (Industrial Minerals, 1985, p. 50).

Andalusite was formerly recovered as a byproduct of corundum mining in the Semiz-Bugu district, central Kazakhstan (Varley, 1965, p. 93). The deposits are in quartzites, which contain $30-80$ percent andalusite and 12-51 percent pyrophyllite. The highest grade material averaged 52 percent $\mathrm{Al}_{2} \mathrm{O}_{3}$, less than 2 percent $\mathrm{Fe}_{2} \mathrm{O}_{3}$, and less than 6 percent combined alkalies. These highgrade reserves were nearly depleted by 1949 . Reserves of lower grade material containing 18 or more percent andalusite were estimated to be 72 million metric tons (Varley, 1965, p. 93).

\section{ZIMBABWE}

Large deposits of kyanite are in northeastern Zimbabwe (Morrison, 1976; Manos. 1978). The top $30 \mathrm{~m}$ of the biotite-kyanite schist at the Ky mine contains an estimated 2 million metric tons of kyanite, which averages 61 percent alumina. The top $6 \mathrm{~m}$ of the biotite-garnetkyanite schist at Madecheche contains an estimated 2.7 million metris tons of lyanite, which contains $58-62$ percent alumina. The gamet could be a coproduct. Kyanite is also found at Masterpiece and Inyanga North, Zimbabwe, but the alunivia sontent and resources are not known. Although these areas are remote and relatively unexplored, they coula sustain a large refractory industry and possibly an aluminum industry.

\section{OTHER COUNTRIES}

Kyanite-group minerals occur in a great many more countries and are far more widely distributed than indicated in the foregoing discussion. For additional information on these minerals, the reader is referred to reports by Klinefelter and Cooper (1961), Varley (1965), and Espenshade (1973). The references in these reports and the bibliography by Grametbaur (1959) list many more reports on the kyanite-group minerals.

Kyanite-group minerals occur in several African countries other than South Africa and Zimbabwe. Andalusite in Swaziland (Davies and others, 1964) occurs as thin veinlets or small pods in the pyrophyllite zone of a diaspore deposit. The andalusite reserves in these rocks are estimated to be 240,000 metric tons (Davies and others, 1964, p. 9). Liberia has approximately 10 million metric tons of measured, indicated, and inferred reserves of metamorphic rock containing an estimated 2.5 million metric tons of kyanite (Stanin and Cooper, 1968, p. 2; Industrial Minerals, 1985, p. 50). 
Kyanite occurs at many places in Kenya (Temperley, 1953; Varley, 1965, p. 45) and was mined during the 1940 's and early 1950's. The best grade kyanite deposits are those in the Murka-Loosoito belt, a 14-km-long belt west of the Coastal Plain. The kyanite occurs in a kyanite-quartz schist. The kyanite shipped between June 1946 and February 1947 contained an average of 61.5 percent alumina (Varley, 1965, p. 46). The identified resources of kyanite in Kenya are 1.2 million metric tons (Industrial Minerals, 1985, p. 50).

Kyanite deposits occur at several places in Namibia. The highest grade material is in the Windhoek district. Other deposits such as those near Rehoboth in the Uisib Valley (Varley, 1965, p. 101-103) apparently have little or no commercial value. One particularly high grade body, about $91 \mathrm{~m}$ in diameter and $24 \mathrm{~m}$ high, of kyanite and corundum in the Windhoek district contained 81.25 percent alumina. The identified resources of kyanite in Namibia are 120,000 metric tons (Industrial Minerals, 1985 , p. 50).

Kyanite occurs in the Provinces of Salzburg, Styria, and Tyrol, Austria (Varley, 1965, p. 85). No kyanite has been produced, but the identified resources are 4 million metric tons (Industrial Minerals, 1985, p. 50).

French production of andalusite is second only to that of South Africa (Industrial Minerals, 1985, p. 45), although French reserves are much smaller than those of South Africa. The French andalusite is produced from Ordovician schist at one mine at Glomel, Brittany (Industrial Minerals, 1985). The French reserves were rerorted to be 3 million metric tons by Potter (1985, p. $42 \%$ and 4 million-5 million metric tons by Industrial Minerals (1985, p. 45).

The andalusite reserves in Spain are not known, but the.t country produced 5,500 metric tons of andalusite in 1983 (Potter, 1985, p. 426, 429). Kyanite production in Spain has been about 5,000 metric tons annually for some years (Industrial Minerals, 1985, p. 46). Kyanite fragments are dredged from alluvial deposits containing as much as 20 percent kyanite in La Corũna Province (Ir dustrial Minerals, 1985).

Lustralia has produced sillimanite from New South Wales, sillimanite and andalusite from South Australia, an a small amount of kyanite from Western Australia (V:rley, 1965, p. 79-84). No current resource data are aveilable for sillimanite and andalusite; the identified res jurces of kyanite in Australia are 3 million metric tons (Ir Justrial Minerals, 1985, p. 50). Australia is evaluating a large industrial topaz deposit in New South Wales, wr ch contains at least 400,000 metric tons of recoverable top $z$ (Potter, 1988, p. 575). According to Industrial Mi: rals (1985, p. 61), this topaz deposit is $30 \mathrm{~km}$ no *heast of Emmaville and contains more than 1.2 million metric tons of topaz in 6 million metric tons of quartz-rich rock known as silexite.

Kyanite and topaz occur in Brazil principally in the States of Minas Gerais and Sao Paulo (Varley, 1965, p. 123). The identified resources of kyanite in Brazil are 3 million metric tons (Potter, 1985, p. 427). Industrial Minerals (1985, p. 47) reported that a deposit of boulder kyanite close to the surface in the State of Goias contained measured reserves of 2 million metric tons.

\section{ALUMINOUS SHALE}

Shale is a fine-grained sedimentary rock formed by the consolidation of clay, silt, or mud; shale has a finely stratified structure that results in fissility that is approximately parallel to the bedding. Almost all shales contain some quartz and other impurities, and many contain organic matter. The most common clay mineral in most shales is illite, which is also called hydromica or sericite. Illite has the same structure as muscovite, which has a theoretical composition of 38.5 percent $\mathrm{Al}_{2} \mathrm{O}_{3}, 45.2$ percent $\mathrm{SiO}_{2}, 11.8$ percent $\mathrm{K}_{2} \mathrm{O}$, and 4.5 percent $\mathrm{H}_{2} \mathrm{O}$. Shale may also contain kaolinite $\left(39.5\right.$ percent $\mathrm{Al}_{2} \mathrm{O}_{3}, 46.5$ percent $\mathrm{SiO}_{2}$, and 14.0 percent $\mathrm{H}_{2} \mathrm{O}$ ), smectite (approximately 28.3 percent $\mathrm{Al}_{2} \mathrm{O}_{3}, 66.7$ percent $\mathrm{SiO}_{2}$, and 5 percent $\mathrm{H}_{2} \mathrm{O}$ ), mixed-layer clay (illite-smectite), or chlorite (approximately 17.6 percent $\mathrm{Al}_{2} \mathrm{O}_{3}, 31.4$ percent $\mathrm{SiO}_{2}, 37.6$ percent $\mathrm{MgO}$, and 13.4 percent $\mathrm{H}_{2} \mathrm{O}$ ). The Cambrian and Ordovician alum shale of Scandinavia chemically consists mainly of hydrated potassium aluminum sulfate (Industrial Minerals, 1977) and is, therefore, quite different in composition from the typical shale.

The aluminous shale and slate (metamorphosed shale) extracted during coal mining and processing are discussed in the following separate section even though they are identical to the aluminous shale discussed in this section. Although extraction of alumina from aluminous shale is not economic at the present time, extraction of alumina from coal waste (shale and slate) may become economic because the cost of mining has already been paid by coal producers.

\section{UNITED STATES}

Aluminous shales are widely distributed in the United States, but none are exceptionally rich in alumina. A thorough search of published and unpublished reports by the staff of the U.S. Bureau of Mines revealed only two districts having shale rich enough in alumina to be considered potential alumina resources (U.S. Bureau of Mines, 1967). One district in Missouri was estimated by Wheeler (1896) to contain 750 million metric tons of Ordovician shale having an average alumina content of 28 percent. The other district near Wenatchee, Wash., 
contains shale in the Swauk Formation of Cretaceous and Paleocene age; Glover (1941) reported its reserves to be between 20 million and 100 million metric tons having an average alumina content of 30-35 percent.

Unlimited quantities of shale are present in the Middle and Upper Cambrian Conasauga Shale, the Lower and Middle Silurian Red Mountain Shale, and the Upper Mississippian Floyd Shale in northwestern Georgia and northeastern Alabama. Most of these shales contain only about 20 percent alumina (Smith, 1931).

Shales of Pennsylvanian age are abundant in the areas where coal is produced in the Eastern United States. Some shales of Pennsylvanian age contain only 20-23 percent alumina (Clarke, 1924, p. 552; Patterson and Hosterman, 1962, table 8). Although too low grade to be an economic source of alumina, the shales of Pennsylvanian age in the United States amount to many billions of metric tons.

The United States also contains very large bodies of younger shale. Much of the 125 million metric tons of aluminous shale and clay in Kansas is of Cretaceous age and contains 20-40 percent alumina (Jewett and others, 1942, p. 129-131).

Extraction of alumina from the Upper Cretaceous Pierre Shale in South Dakota has been considered (Gries, 1942 , p. $63-66$; Rothrock, 1944 , p. 65-66), and chemical engineering students at the South Dakota School of Mines and Technology have studied this problem (Miller, 1959 , p. 26). The Pierre Shale, however, is not a potential source of aluminum because it contains only 12-18 percent alumina (Tourtelot, 1962, table 7).

Shales of Tertiary age occur in the southern and western parts of the United States. Glover (1941) listed several scattered deposits of Tertiary shale and clay in Washington in addition to those in the Wenatchee district.

\section{CANADA}

The Canada Department of Mines and Technical Surveys investigated the recovery of alumina from shales in Newfoundland, Nova Scotia, and New Brunswick (see table 6) (Thomas and Ingraham, 1959; Winer and Quon, 1979, table 2). Dean (1975) found that these shales are of Cambrian, Ordovician, and Pennsylvanian age and that most of the shales average 20-24 percent alumina. Upper Cretaceous shale that correlates with the Pierre Shale in the United States is present in the Canadian Great Plains region. This shale has received very little attention as a potential source of alumina because its alumina content is less than that of the Whitemud Formation in southern Saskatchewan; the Whitemud has a large shale resource that contains 20-24 percent alumina (Bell and Brady, 1976; Bell, 1978, 1979).

\section{SPAIN}

The Puentes de Garcia Rodriguez Tertiary clay and the Carboniferous slate in northwestern Spain were investigated by the Empresa Nacional del Aluminio and the Escuela Técnica Superior de Ingenieros de Minas (Sancho, Iglesias, and others, 1981; Sancho, Verdeja, and others, 1981). The alumina content of the clay is 20 percent, and that of the slate is 22 percent. The mineral composition of these materials is shown (in weight percent) in the following table from Sancho, Verdeja, and others $(1981$, p. 84,91$)$ :

\begin{tabular}{|c|c|c|}
\hline Component & $\begin{array}{l}\text { Puentes de Garcia } \\
\text { Rodriguez clay }\end{array}$ & $\begin{array}{c}\text { Carboniferous } \\
\text { slate }\end{array}$ \\
\hline Kaolinite & 24 & 11 \\
\hline Illite $\ldots, \ldots, \ldots, \ldots, \ldots$ & 31 & 46 \\
\hline Chlorite... & 0 & 9 \\
\hline Mixed-layer clay $\ldots \ldots \ldots \ldots$ & 0 & 6 \\
\hline Quartz $\ldots \ldots \ldots \ldots \ldots \ldots \ldots$ & 28 & 20 \\
\hline Organic matter............ & 2 & 0 \\
\hline Other.. & 15 & 8 \\
\hline Total... & 100 & 100 \\
\hline
\end{tabular}

\section{SWEDEN}

Sweden has very large resources of Cambrian and Ordovician alum shale, a marine black shale, in Väs ergötland, Östergötland, Närke, Öland, and Sc nia (Shaikh, 1977, p. 192). The sulfur-rich alum shale contains oil, vanadium, potassium, uranium, and alumi um (Duncan and Swanson, 1965, p. 25; Shaikh, 1977, p. 272 ). During the period 1942 to 1962 , about 10 million bar'els of oil were produced from the alum shale from $\mathrm{N}$.ke (Duncan and Swanson, 1965, p. 25). Byproducts of the alum shale included substantial amounts of combus ble gas, heat for electric power generation, sulfur, ammc ia, lime, and brick clay (Gejrot, 1958).

AB Svensk Alunskifferutveckling was formed by oliden $\mathrm{AB}$ and Luossavaara-Kirunavaera $\mathrm{AB}$ (LKAE in 1977 to mine alum shale in Sweden (Industrial Mine als, 1977). Plans were made to mine 6 million metric tor s of shale annually at Ranstad in Västergötland; that s ale would have contained about 355,000 metric tons of 1 luminum (Shaikh, 1977, p. 192). Information on whe her alum shale was ever used as a source of alumina is not available; however, almost all of Sweden's alum um production is from imported bauxite.

The alum shale of Sweden varies in composit: In places, it is rich in organic matter, and the ${ }^{\cdots}$ ina content is generally less than 20 percent (Shaikh, $\cdots, p$. 192). The Swedish National Board of Industry ID) has stated that the quantity of alum shales in $S_{-1}^{-1}$ is 600 billion metric tons, and additional resov.... are likely to be present in the mountain ridges

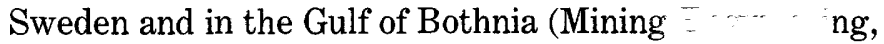
1977). 


\section{OTHER COUNTRIES}

The distribution of aluminous shale and slate throughout the world is poorly known. The alum shales that occur in Sweden are also in Denmark and Norway (Shaikh, 1977, p. 192). However, there is no information available to indicate that these shales were ever investigated as a source of alumina. The deposits in Denmark are on the island of Bornholm, and those in Norway are in the Oslo-Ringerike area and in the Mjösa-Ringsaker district. Aluminous slate occurs in Wales and Scotland and in Cornwall and the Lake District, England (Crocket, 1975). The Japanese recovered alumina during World War II from shales mined in Manchuria (table 1 ); these shales contained boehmite $\left(\mathrm{Al}_{2} \mathrm{O}_{3} \cdot \mathrm{H}_{2} \mathrm{O}\right)$ and diaspore $\left(\mathrm{Al}_{2} \mathrm{O}_{3} \cdot \mathrm{H}_{2} \mathrm{O}\right)$ and were, therefore, a type of bauxite.

\section{COAL WASTE AND COAL ASH}

Coal wastes are the several types of aluminous materials discarded during coal mining and treatment. Overburden or spoil is the material above the coal removed during strip mining. Washing rejects obtained during the purification or beneficiation process of washing the coal with water are the partings or bands of waste in the coal bed. Roof rock or draw slate is the soft shale or slate above the coal bed; it is extracted with the coal in some underground mines to provide headroom. Carbonaceous shale and impure fissile anthracite are called culm in the coal industry. Culm is discarded in piles known as banks, and if the banks burn by spontaneous combustion, then the resulting material is known as red dog.

Draw slate and washing rejects are the coal wastes most likely to be used as sources of alumina, and they are readily available in refuse stockpiles wherever coal is mined. Coal waste is an impure mixture consisting principally of fine coal, silicate minerals, including clay minerals, and iron minerals such as pyrite and siderite. Most of the alumina in coal waste is in the clay minerals kaolinite and illite. The alumina content of draw slate is reported to range from 15 to 35 percent (Shafer and Solomon, 1967); however, draw slates having alumina contents at the high end of the range probably are not very abundant. The alumina content of washing rejects is probably highly variable.

Coal-washing rejects obtained annually contain more alumina than the world produces annually. In 1973, the annual world production of coal was 2,200 million metric tons; washing rejects associated with this production were estimated to amount to 600 million-1,200 million metric tons that contained 120 million-240 million metric tons of alumina (Cohen and Mercier, 1976, p. 6). The world production of aluminum in 1976 was about 14 million metric tons per year (Cohen and Mercier, 1976, p. 3 ), which was obtained from about 26 million metric tons of alumina.

The noncombustible residues of coal are classed under the general term "ash." Fly ash is the fine-grained material carried out of the combustion chamber by draft and deposited in the quiet places of the furnace and flue system or discharged with the waste gases. The coarser material is usually called ash or bottom ash because most of it passes through the grates. Clinker is the fused or partly fused form of ash. Slag is formed in some furnaces when the bottom ash is dropped into water.

Recovery of aluminnm from ash from coal-fired powerplants has been studied, but such material is less attractive than coal waste because high temperature affects the alumina solubility. Shafer and Solomon (1967) have shown that the extractability of alumina from draw slate by use of sulfuric acid $\left(\mathrm{H}_{2} \mathrm{SO}_{4}\right)$ increases in material heated to $500{ }^{\circ} \mathrm{C}$ but drops off markedly in material heated higher than $500{ }^{\circ} \mathrm{C}$. This is the approximate temperature at which kaolinite and most illites lose their crystal structure and begin to form a high-temperature phase. Because fly ash and bottom ash or slag form at temperatures considerably above $500{ }^{\circ} \mathrm{C}$, the alumina is difficult to extract.

\section{UNITED STATES}

According to Sorensen and Schaller (1983, p. 2), about 80 million metric tons of shale are discarded annually from coal mines and coal treatment plants in the United States, and over the years, about 3 billion metric tons of this material have accumulated. The total ash produced annually is about 70 million metric tons, and about 500 million metric tons have accumulated. About 20 percent of this ash is bottom ash or slag, and fly ash accounts for 10-90 percent of the ash produced in the United States from coal that yields $3-30$ percent ash.

A study of coal waste by Sorensen and Schaller (1983, p. 12-13) led to the conclusion that of all coal waste in the United States, culm in the Anthracite district in eastern Pennsylvania is the most attractive potential source of alumina. These authors gave the following reasons for this conclusion: (1) anthracite waste materials have accu-, mulated in about 800 banks for a total of about 688 million $\mathrm{m}^{3}$; (2) these waste materials are unsuitable for construction materials, such as lightweight aggregate; (3) continued storage of the waste material containing coal and sulfides and other leachable compounds poses environmental pollution and combustion hazards, and the district has become more populated than most other coal districts; (4) the waste material in the Anthracite district generally has a higher alumina content than the wastes of other coal districts; and (5) most of the waste in the 
TABLE 14. - Typical composition of anthracite culm in Pennsylvania

[Data from Apa and others (1982). Heating value of ash is $6,745-10,700 \mathrm{~kJ} / \mathrm{kg}$ ]

\begin{tabular}{|c|c|}
\hline Constituent & Percent by weight \\
\hline \multicolumn{2}{|c|}{ Composition of culm } \\
\hline $\mathrm{C}$ & 21-32 \\
\hline $\mathbf{H}$ & $1.4-2.0$ \\
\hline 0 & $3.4-7.0$ \\
\hline $\mathbf{N}$ & $0.5-1.5$ \\
\hline S. . & $0.4-1.2$ \\
\hline Ash & $57-70$ \\
\hline
\end{tabular}

\begin{tabular}{|c|c|}
\hline \multicolumn{2}{|c|}{ Composition of culm ash } \\
\hline 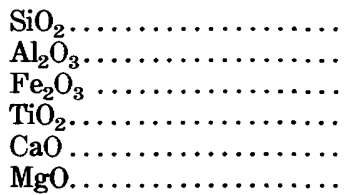 & $\begin{array}{c}50-57 \\
30-37 \\
3-10 \\
1-2 \\
1-2 \\
0-1\end{array}$ \\
\hline 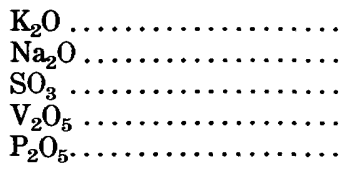 & $\begin{array}{c}1-3 \\
1-3 \\
0-1 \\
0.2-0.4 \\
0.2-0.4\end{array}$ \\
\hline
\end{tabular}

Anthracite district contains sufficient coal for the calcination step in the alumina extraction process.

Apa and others (1982) studied extraction of alumina from anthracite culm in the Pennsylvania Anthracite district; they estimated that 696 million $\mathrm{m}^{3}$ of culm is present in 863 separate banks and contains $30-40$ percent anthracite. The culm ash contains $50-57$ percent $\mathrm{SiO}_{2}$, 30-37 percent $\mathrm{Al}_{2} \mathrm{O}_{3}$, and 3-10 percent $\mathrm{Fe}_{2} \mathrm{O}_{3}$ (table 14).

Robl and Bland (1977, p. 98) found that shale and clay associated with coal in the Appalachian basin of eastern Kentucky contain 20.8-37.5 percent alumina. One particularly valuable low-sulfur coal (Hazard No. 4) has a clay parting that yields 1 metric ton of waste for every 2 metric tons of coal produced. Because of the demand for low-sulfur coal, large tonnages of Hazard No. 4 coal are mined, and large tonnages of waste are made available. An ashed sample of this waste contained 35.20 percent alumina (Robl and Bland, 1977, table 4).

\section{CANADA}

Table 6 shows Winer's (1977) estimates of the alumina content of Canadian coal wastes. Winer and Tibbetts (1976), of Canada's Centre for Mineral and Energy Technology (CANMET), evaluated the coal wastes in Canada as potential sources of alumina. They found that (1) the coal-mine waste and washing rejects from Alberta and British Columbia represent the best potential sources of alumina of all Canadian coal waste; (2) the Hat Creek district located $193 \mathrm{~km}$ northeast of Vancouver, British Columbia, is the best potential source of coalassociated alumina in Canada both qualitatively and quantitatively; and (3) in 1976, the amount of coal ash generated at any one place in Canada was not sufficient to be considered a potential source of alumina. However, large tonnages of ash may become available in the future when very large coal-fired powerplants are constructed in British Columbia and Alberta. Therefore, coal ash may become a potential nonbauxite source of alumina.

The British Columbia Hydro Power, Ltd., obtained a license to explore part of the Hat Creek coal district. This district has coal whose ash contains as much as 32 percent alumina (Winer, 1977, p. 104; Winer and Tibbetts, 1978). Estimated resources of lignite in the Hat Creek district in 1978 were 460 million metric tons of proved reserves, 572 million metric tons of indicated reserves, and 1,113 million metric tons of inferred reserves.

\section{UNITED KINGDOM}

Wills and Phillips (1977) reported that colliery spoil (coal-mine waste) is a potential source of alumina in the United Kingdom. Material available in 1966 included about 1.2 billion metric tons of unburned coal-mine waste containing 19.4 percent alumina, about 630 million metric tons of burning waste (no alumina analysis), and about 320 million metric tons of burned waste containing 21.2 percent alumina.

\section{OTHER COUNTRIES}

Roasting of shale associated with coal in France yields a product having a typical composition of 24.4 percent $\mathrm{Al}_{2} \mathrm{O}_{3}, 7.8$ percent $\mathrm{Fe}_{2} \mathrm{O}_{3}, 0.65$ percent $\mathrm{Na}_{2} \mathrm{O}, 4.4$ percent $\mathrm{K}_{2} \mathrm{O}, 1.9$ percent $\mathrm{MgO}, 0.25$ percent $\mathrm{P}_{2} \mathrm{O}_{5}, 0.9$ percent $\mathrm{TiO}_{2}$, and 57.9 percent $\mathrm{SiO}_{2}$ (Cohen and Mercier, 1976, p. 8). Fly ash tested in a pilot plant at the Tatabanya coal mines in Hungary has the following composition: 29-31 percent $\mathrm{Al}_{2} \mathrm{O}_{3}, 41-45$ percent $\mathrm{SiO}_{2}, 9-12$ percent $\mathrm{Fe}_{2} \mathrm{O}_{3}$, 6 percent $\mathrm{CaO}, 2$ percent $\mathrm{MgO}, 2$ percent $\mathrm{S}$, and $1-2$ percent loss on ignition (Gulyás and Vámos, 1976). Coal-mine waste from the Ekibastuz coal field in the U.S.S.R. contains $22-30$ percent $\mathrm{Al}_{2} \mathrm{O}_{3}$ (Sukhanova and Ponomarev, 1969).

\section{MISCELLANEOUS SOURCES OF ALUMINA}

\section{COPPER LEACH SOLUTIONS}

The USBM and the Kennecott Copper Corporation investigated the recovery of alumina from circulating solutions used to extract copper from waste dumps at many of the porphyry copper mining operations. These solutions contained 3.0-11.9 g/L alumina and could have yielded approximately 500,000 metric tons of alumina each year in the United States (Petrick and others, 1973) 
before many of the copper mines were closed. These figures are only estimated because of variations in leaching rates and concentration of alumina in the solutions.

George and others (1968) suggested that as much as 2,000 metric tons of alumina per day could have been recovered from copper leach solutions in the 1960's when 14 copper mines were active in the United States. Because many copper mines closed during the last three decades, copper leach solutions are not likely to provide significant amounts of alumina. Furthermore, the National Materials Advisory Board (1970, p. 60) concluded that, although extracting alumina from copper leach solutions may prove economic, this raw material is not a potentially large source of alumina.

\section{GIBBSITIC SOILS}

Gibbsitic soils are present in scattered deposits on the U.S. Atlantic Coastal Plain and occur in a broad belt on the U.S. Gulf of Mexico Coastal Plain; the belt extends $550 \mathrm{~km}$ from southern Mississippi to west-central Georgia (Clarke, 1971; White, 1984). Gibbsite $\left(\mathrm{Al}_{2} \mathrm{O}_{3} \cdot 3 \mathrm{H}_{2} \mathrm{O}\right)$ is most abundant in the clay- and silt-sized fractions of the $\mathrm{B}$ and $\mathrm{C}$ soil horizons. The clay and silt fractions made up 15-52 percent of the 10 samples examined by Clarke (1971, table 1), and the gibbsite content of the clay and silt fractions ranged from 15 to 45 percent. Other minerals in the clay and silt fractions were kaolinite, quartz, hematite, vermiculite, and illite. Alumina contents of the clay and silt fractions ranged from 28 to 43 percent. Over much of the two coastal plains, the gibbsite content in soils and saprolite is low to negligible; therefore, gibbsitic soils are not likely to become an important resource of alumina.

\section{ZUNYITE}

Zunyite, $\mathrm{Al}_{13} \mathrm{Si}_{5} \mathrm{O}_{20}(\mathrm{OH}, \mathrm{F})_{18} \mathrm{Cl}$, has an $\mathrm{Al}: \mathrm{Si}$ ratio of 13:5. The regional distribution of zunyite in the United States is similar to that of high-fluorine silicic volcanic rocks, and zunyite is commonly associated with alunite (Hall, 1978; Coats and others, 1979). It was originally described from the Zuni mine near Silverton, Colo. (Hillebrand, 1885).

One major occurrence of zunyite in the United States is in the south half of sec. 3, T. 40 N., R. 47 E., Elko County, Nev. It occurs in an outcrop approximately 365 $\mathrm{m}$ long and 3-18 $\mathrm{m}$ wide (Coats and others, 1979). The depth is not known, and no reserve estimates are available. The chemical analyses of two samples averaged 26.6 percent $\mathrm{SiO}_{2}, 58.2$ percent $\mathrm{Al}_{2} \mathrm{O}_{3}, 9.6$ percent $\mathrm{H}_{2} \mathrm{O}$, 2.5 percent $\mathrm{Cl}$, and 5.3 percent $\mathrm{F}$.

Coats and others (1979) reported that zunyite has been found in the United States at Butte, Mont.; in the Red Mountain district, Ouray County, Colo.; in the Bonanza district, Saguache County, Colo.; in the Tintic district, Utah; and in porphyry copper deposits, Puerto Rico. They also mentioned reports of zunyite from Ishidoriya district, Japan; Cerro de Pasco, Peru; Azrou-Melloul, Morocco; Beni-Embarek, Algeria; near Postmasburg, South Africa; and the U.S.S.R., where zunyite occurs in the Kabansk deposit of massive pyrite in the Ural Mountains and is associated with alunite in many localities. Worldwide, zunyite is a rare mineral, but local concentrations may one day be a source of aluminum and fluorine.

\section{ALUMINA EXTRACTION RESEARCH}

\section{RESEARCH BEFORE WORLD WAR II}

Probably the first preparation of aluminum from nonbauxite material was in Denmark in 1825 by H.C. Oersted, who produced aluminum by heating potassium amalgam with aluminum chloride and distilling the mercury from the resulting aluminum amalgam (Edwards and others, 1930, p. 2). Oersted called the aluminum "metal of clay," but the source and type of raw material are unknown, and so we are not certain that he used clay. Oersted's process was never used commercially. After the Bayer process for obtaining alumina from low-silica bauxite was developed in the late 1800 's, all aluminum was made by the reduction of alumina by the HallHéroult electrolytic method.

The following brief history on the production of alumina from nonbauxite material is from information published by Edwards and others (1930, p. 155-235). R.A. Tilghman received U.S. patent 5,383 in 1847 for a process to recover alumina from aluminum phosphate. In 1858, Le Chatelier applied for British patent 413 for a process using hydrofluosilic acid, made by passing steam over a heated mixture of fluorspar and silica, to recover soluble aluminum fluosilicate from clay. A process for the recovery of alkali aluminate from blast furnace slag was proposed in 1862. In 1871, J. Townsend applied for British patent 995 for a process to recover alumina from natural aluminum phosphates.

Between 1890 and 1910, only a few processes for the extraction of alumina from nonbauxite materials were proposed, but between 1910 and 1930, many processes were patented, including the following: (1) hydrochloric acid processes for recovering alumina from leucite (Italy), clay (United States), and calcined clay (England); (2) nitric acid processes for recovering alumina from leucite in Italy, England, and the United States and from labradorite in Norway; (3) a hydrofluoric acid process for treating clay or kaolin in the United States and feldspar in the United States and England; (4) a sulfuric acid 
process for recovering alumina from alunite in the United States; (5) the treatment of pulverized clay with sodium hydroxide under pressure in the United States (Bayer process); (6) the treatment of aluminum silicates such as leucite with concentrated sodium hydroxide and lime after part of the silica was removed with alkali hydroxide in France; (7) the digestion of feldspar with alkali carbonate under pressure to dissolve silica and leave alumina and iron oxide in the United States; (8) the digestion of clay with strong sodium hydroxide under pressure, then the separation of alumina and silica by fractional precipitation in the United States; (9) the treatment of alunite with barium hydroxide solution under pressure in the United States; (10) the digestion of aluminous iron ores by sodium hydroxide in the United States; (11) the roasting of cryolite and caustic lime and leaching in water in the United States; (12) the digestion of cryolite with calcium carbonate and alkali carbonate in Germany; (13) the digestion of natural aluminum phosphates with sodium or potassium hydroxide in Germany; (14) the treatment of aluminum chloride with alkali chloride in Japan; (15) the treatment of calcium aluminum phosphate with caustic soda solution and sodium silicate to combine with alumina in England; and (16) the leaching of a mixture of aluminum and calcium phosphate to form calcium aluminate and volatile phosphorus pentoxide in the United States. The foregoing is by no means a complete list of all the proposed processes for extracting alumina from nonbauxite material, and in addition, there are many patented modifications to both the alkali and acid digestion processes.

\section{U.S. RESEARCH DURING WORLD WAR II}

During World War II (1941-45), the United States had its bauxite imports from Suriname and Guyana seriously reduced by submarine warfare. As a consequence, the U.S. Government formed the Defense Plant Corporation and authorized the construction of four experimental plants at Laramie, Wyo., Harleyville, S.C., Salt Lake City, Utah, and Salem, Oreg. A fifth plant, at Oak Ridge, Tenn., was operated by the Tennessee Valley Authority (TVA) under the authorization of the War Production Board and under the direction of the Metallurgy Committee of the National Academy of Sciences. Also during World War II, the U.S. Bureau of Mines (USBM) developed a lime-soda sinter process for extracting alumina from low-grade materials. The materials studied included Wyoming anorthosite (Brown and others, 1947), South Carolina kaolin (Cservenyak, 1947), and nodular diaspore clay from Clearfield County, Pa. (Conley and others, 1947).

The plant $5 \mathrm{~km}$ south of Laramie, Wyo., was designed to recover alumina from anorthosite by an alkali-sinter process (St. Clair and others, 1959; Kirby and Barclay, 1981, p. 5-6). This plant was not finished when the program was terminated in 1945 . It sat idle until the U.S. Bureau of Mines reconditioned it and operated it from 1952 to 1954. The plant was designed for the USBM by the Dorr Company in cooperation with Monolith Portland Midwest Company. The process tested (St. Clair and others, 1959, p. 13-14) consisted of the following steps: (1) preparing a slurry of anorthosite, limestone, and soda by grinding to minus-200 mesh; (2) drying and sintering the slurry at about $1290{ }^{\circ} \mathrm{C}$; (3) grinding the dried material with a soda solution and removing the resulting sodium aluminate solution; (4) desilicating the sodium aluminate solution by pumping it under pressure through preheaters at $100{ }^{\circ} \mathrm{C}$, adding lime, and autoclaving at $160^{\circ} \mathrm{C}$; (5) carbonating the desilicated solution to precipitate alumina hydrate; and (6) purifying the alumina hydrate in a hydroseparator and calcining it at $1232{ }^{\circ} \mathrm{C}$ to recover alumina.

The plant at Harleyville, S.C., tested the extraction of alumina from South Carolina kaolin by the lime-sinter method (Archibald and Jackson, 1944; Archibald and Nicholson, 1949). The plant was built and operated for the Defense Plant Corporation by Ancor Corporation, which had been formed by Paraminas, Inc., and American Nepheline Corporation. Kaolin was sintered with limestone in a rotary kiln at $1315{ }^{\circ} \mathrm{C}$. The resulting material was ground and leached for 20 minutes at $70^{\circ} \mathrm{C}$ with a solution having a 2:1 mole ratio of $\mathrm{Na}_{2} \mathrm{O}$ to $\mathrm{Al}_{2} \mathrm{O}_{3}$ and a concentration equivalent to $85 \mathrm{~g} \mathrm{Al}_{2} \mathrm{O}_{3}$ per liter of solution. Desilication was increased by adding a colloidal agent to serve as collectors or crystal growth centers. This lime-sinter method required more than 2 metric tons of limestone to process 1 metric ton of kaolin.

The plant at Salt Lake City, Utah, was designed to produce 100 metric tons of alumina a day from alunite from the Marysville district, Utah (Fleischer, 1944; Hall, 1978, p. A10). The plant used the Kalunite process developed by Kalunite, Inc. The process involved the treatment of alunite with sulfuric acid and the production of potassium alum. By heat treatment under pressure, the potassium alum was converted to a water-insoluble compound, a basic alum precipitate, and sulfuric acid and potassium sulfate were regenerated. The basic alum precipitate was calcined to produce a mixture of potassium sulfate and alumina, which was separated by autoclave treatment. The Kalunite process was also tested on clays.

The plant at Salem, Oreg., tested the ammonium sulfate process on kaolin from the Western United States (Seyfried, 1949). In the process, which was designed by the Chemical Construction Corporation, the roasted clay was leached with molten ammonium bisulfate and water to form a slurry. During controlled cooling, nearly all of 
the alumina crystallized in the form of ammonium alum. Alumina was then recovered by a method similar to the one used by the Kalunite process described above.

The testing done by the Tennessee Valley Authority at Oak Ridge, Tenn. (Copson and others, 1944a, b; Hignett, 1947), was on the extraction of aluinina from clay by the lime-sinter modification of the Pedersen (1927) process. It involved the following steps: (1) heating a mixture of clay and limestone to form a sinter containing calcium aluminate and dicalcium silicate; (2) leaching of the sinter with a sodium carbonate solution to form a sodium aluminate solution and a residue of calcium carbonate and calcium silicate; (3) treating the sodium aluminate solution with carbon dioxide to precipitate aluminum trihydrate and regenerate sodium carbonate, which was recycled; and (4) calcining the aluminum trihydrate to produce alumina. The TVA investigated the geology and resources of the western Tennessee high-alumina clay deposits (Gildersleeve and Whitlatch, 1944) as a possible raw material for the extraction process described above.

\section{INVESTIGATIONS BY U.S. GOVERNMENT AGENCIES AFTER WORLD WAR II}

In 1970, the National Materials Advisory Board, which was part of the National Research Council, published a report reviewing the most promising processes for obtaining alumina from nonbauxite sources in the United States. The most promising method appeared to be an acid process for the treatment of kaolin. The report recommended that the U.S. Bureau of Mines, with help from the aluminum industry, build and operate pilot plants to test the hydrochloric acid and nitric acid processes for extracting alumina from kaolin.

\section{U.S. BUREAU OF MINES}

\section{Miniplant Studies}

After World War II, the U.S. Bureau of Mines continued to investigate many processes for extracting alumina from nonbauxite material, including the alkali-sinter process to obtain alumina from anorthosite near Laramie, Wyo. (see the section above, "U.S. Research During World War II"), and the lime-soda sinter process to obtain alumina from anorthosite in the San Gabriel Mountains, Calif. (Lundquist, 1963). Following the recommendation of the National Materials Advisory Board (1970), the USBM attempted to begin miniplant studies in July 1971 to reexamine the technology for recovering alumina from domestic nonbauxite sources, but lack of funds and insufficient industry interest caused negotiations to fail (Kirby and Barclay, 1981, p. 3). The USBM began the miniplant program in July 1973 a few months before the Organization of Petroleum Exporting Countries (OPEC) imposed an oil embargo on the United States. Fears that bauxite-producing countries would impose a similar embargo encouraged companies to respond to another invitation in January 1974 to participate in the miniplant program. Participants in the program between 1974 and its conclusion in 1982 were listed by Barclay (1984, p. 166) as (1) Alcan International, Ltd.; (2) Aluminum Company of America; (3) Anaconda Aluminum Company; (4) Amax Aluminum Company, Inc.; (5) Billiton International Metals; (6) Combustion Engineering, Inc.; (7) Consolidated Aluminum Corporation; (8) Kaiser Aluminum and Chemical Corporation; (9) Martin Marietta Aluıninum, Inc.; (10) Reynolds Metals Company; and (11) Vereinigte Aluminium-Werke A.-G. Six miniplants were to be constructed at Boulder City, Nev., but only two were actually built and operated (Barclay, 1984). The term "miniplant" was chosen to indicate a testing scale beyond the usual laboratory facilities but not as large as a pilot plant.

The objectives of the miniplant tests were to select the most favorable processes and raw materials, on the basis of relative costs and technical factors, and to make a preliminary design for a pilot plant to use the best process to treat 10-50 metric tons of ore per day (Bengston and others, 1978a, b, 1979, 1981; Nunn and others, 1979). The following six processes were chosen for study because they were believed to be the most promising: (1) nitric acid leaching of clay; (2) hydrochloric acid leaching of clay followed by evaporative crystallization of aluminum chloride hexahydrate; (3) hydrochloric acid leaching of clay followed by hydrochloric acid gas sparging crystallization of aluminum chloride hexahydrate; (4) sulfurous acid leaching of clay; (5) sintering anorthosite with limestone and leaching the dried material with a caustic solution; and (6) reducing alunite by roasting followed by caustic leaching.

Process 1, Nitric acid leaching of clay.-The nitric acid leaching of calcined clay was tested in the first miniplant (Olsen and others, 1983b; Barclay, 1984, p. 167-168). This process was selected because of the recommendation of the National Materials Advisory Board (1970) and because of the widespread interest in it. Between 1965 and 1975, 14 U.S. patents were issued for the recovery of alumina from clay by the nitric acid process. Five of these patents were assigned to Arthur D. Little, Inc. (George and Stone, 1965; Beutner and Huska, 1971; Flood, 1971; Hyde and Margolin, 1971; Huska and others, 1972), four to Allied Chemical Corporation (Amano and Taylor, 1968; Gerry and others, 1968; Kelly and Yodis, 1968; Yodis and Schnoor, 1968), and five to Reynolds Metals Company (Brown and Hrishikesan, 1966; Kelly and Bruen, 1971; Wise, 1971; Royce and 
Drown, 1974; Bruen and Kelly, 1975). The investigations of the nitric acid process by the USBM were described by Bengston and others (1978a, b), Sorensen (1982), and Olsen and others (1983b). With additional work, the USBM found that the consumption of nitric acid was excessive (White, Henry, and Traut, 1982; Turner and Rogers, 1983). Bengston and others (1978a, b) also found that the capital, operating, and energy costs for the nitric acid process were significantly higher than those for the two processes using hydrochloric acid. Technical research on the nitric acid leaching of clay has been outlined by the following: Eisele and others (1982), Sorensen (1982), White, Henry, and Traut (1982), Olsen and others (1983b), and Turner and Rogers (1983).

Process 2, Hydrochloric acid leaching of clay followed by evaporative crystallization of aluminum chloride hexahydrate. - The recovery of alumina from calcined clay by hydrochloric acid leaching followed by evaporative crystallization of aluminum chloride hexahydrate was initially selected for the second miniplant because considerable research had already been done on it by industry and by the USBM. A pilot plant designed to extract alumina from clay by the hydrochloric acid process was operated by Chemische Fabrik GriesheimElektron in Germany from 1924 to 1928 (Belsky and others, 1981, p. 102). However, this process was not tested in a miniplant because hydrochloric acid leaching followed by gas sparging crystallization was more efficient.

Process 3, Hydrochloric acid leaching of clay followed by hydrochloric acid gas sparging crystallization of aluminum chloride hexahydrate. - The second miniplant was built to test the hydrochloric acid leaching of calcined clay followed by hydrochloric acid gas sparging crystallization of aluminum chloride hexahydrate. This process has the greatest potential of the six studied to be commercially useful. Barclay (1984, p 171-172) cited 25 reports on the process, including USBM reports by the following authors: Good and others (1966), Singleton and others (1968), Eisele and others (1976, 1983), Eisele (1980), Sorensen and others (1981, 1983), Doerr (1982), Maysilles and others (1982), Olsen and others (1982, 1983a, c), Turner and others (1982), Miller and others (1983), Sawyer and others (1983), Hunter and others (1984), and Sorensen and Sawyer (1984). Additional research on the recovery of alumina from clay by the hydrochloric acid leach process was reported in the following references: Brown and others (1979), Gokcen (1980, 1983), Covino and others (1981), Shanks and others (1981), Schaller and others (1982), White, Henry, and Krogh (1982), Ko and others (1983), Rao and Soleiman (1983), Bauer and others (1984), and Bremner and others (1984).
Process 4, Sulfurous acid leaching of clay.-The USBM considered making miniplant tests of a sulfurous acid process applied to calcined clay but decided not to do so (Barrett and others, 1973; Barclay, 1984, p. 175-177). The process had been used on a semicommercial scale in Germany in 1938 (Anderson, 1940, p. 275) and during World War II, and patents were obtained in the 1930's and 1940's, as listed by Peters and others (1962, p. 21) and Raddatz and others (1981, p. 15). The decision not to build a miniplant to test the sulfurous acid process was based on a USBM laboratory study (Raddatz and others, 1981) and on cost evaluations (Kramer, 1983; Kramer and Peters, 1983) indicating that this process has high energy consumption, excessive capital and operating costs, and long leaching time. The process has only a 67 percent recovery of aluminum from clay, and the final product has contents of $\mathrm{K}_{2} \mathrm{O}, \mathrm{Cr}_{3} \mathrm{O}_{3}, \mathrm{P}_{2} \mathrm{O}_{5}$, and $\mathrm{SiO}_{2}$ higher than those specified for cell-grade alumina (alumina to be supplied to a cell for electrolytic production of aluminum metal).

Process 5, Sintering anorthosite with limestone and leaching the dried material with a caustic solution.USBM research on the extraction of alumina from anorthosite by the lime-sinter caustic leaching process was described by Hayashi (1982) and Edlund (1982). Miniplant support studies, not complete tests, were made of the process (Ampian, 1967; Hayashi, 1982; Barclay, 1984, p. 179-185). The objective of these studies was to resolve the problems that plagued the pilot plant operated by the USBM at Laramie, Wyo., shortly after World War II (St. Clair and others, 1959). Research on this problem (Edlund, 1982) was encouraging, but a miniplant was not built and operated because the Kaiser contract studies (Bengston and others, 1978a) showed this process to be as much as twice as costly as the two processes using hydrochloric acid to leach clay.

Process 6, Reducing alunite by roasting followed by caustic leaching. - The USBM had planned miniplant tests of the roasting of alunite followed by caustic leaching. When Alumet announced plans for a pilot plant to test this technology (see the Alumet section below), the USBM avoided duplicating Alumet's work (Kirby and Barclay, 1981, p. 7). However, the USBM did research on the reduction roast step in which fine alunite ore was pelletized and roasted (Riley and others, 1983).

\section{OTHer STUdies}

In addition to the six processes considered for miniplant tests, other processes have been studied by the USBM. Descriptions of USBM research on dawsonite are included in a separate section titled, "Investigations of U.S. Dawsonite." Work on the recovery of alumina from coal ash was done by Eisele and Bauer (1979), 
Gabler and Stoll (1983), and Sorensen and Schaller (1983). Apa and others (1982) studied extraction of alumina from anthracite culm in Pennsylvania. The culm ash content is given in table 14. After the ash was burned in a fluid-bed calciner and leached with sulfuric acid, about 80 percent of the alumina in the bed ash and 90 percent of the alumina in the cyclone fines were leached. The leaching efficiency was greatly reduced in culm that had been heated sufficiently to form mullite.

Dilute sulfuric acid has been used to leach copper from mine dumps and low-grade copper ores. This acid also removes aluminum and other metallic ions from the material (National Materials Advisory Board, 1970, p. 57-60). The USBM investigated the possibility of recovering the alumina from the acid-sulfate solution (George and others, 1968; Petrick and others, 1973). Additional research by the USBM on extracting alumina from copper leach solutions is described by Iverson and Leitch (1968) and May and Seidel (1976). However, no U.S. commercial extraction of alumina from copper leach solutions is known.

Sawyer and Turner (1985) developed a method of pressure leaching raw kaolin. Pressure leaching of kaolin has a potential for bypassing the calcining step that had been required in earlier investigations.

The USBM did some research on the recovery of alumina from aluminum chloride obtained by carbochlorination of high-alumina clay - that is, chlorination of clay in the presence of carbon or carbon monoxide (Good and others, 1966; Singleton and others, 1968; Kirby and others, 1970). Research on this process was summarized by Landsberg (1975, 1977, 1983) and Landsberg and Wilson (1984). Mah (1982) compiled the thermodynamic data for chlorination reactions, and Gokcen (1983) evaluated rates of chlorination of aluminous materials.

Alumina extraction from unsintered anorthosite by leaching with hydrochloric acid and fluoride was described by Bremner and others (1982) and Eisele and Bauer (1983). Leaching was followed by hydrochloric acid gas sparging. This process would save energy by avoiding sintering of anorthosite. However, the energy saved would be needed to recover chloride and fluoride ions for recycling. Recycling the chloride and fluoride would consume more energy than recycling chloride after process 3 described above.

\section{U.S. DEPARTMENT OF ENERGY}

In 1977, the U.S. Department of Energy (DOE) succeeded the U.S. Energy Research and Development Administration (ERDA), which had been formed in 1973. Both agencies have conducted and sponsored investigations related to the recovery of alumina from nonbauxite materials. Included are studies of dawsonite in oil shale by the Energy Technology Center, Laramie, Wyo., which are described in the section titled "Investigations of U.S. Dawsonite." Also included are studies of fly ash and other coal wastes by the Oak Ridge National Laboratory, Oak Ridge, Tenn. (DeCarlo and others, 1978; Egan and others, 1980; Kelmers and others, 1981; Seeley and others, 1981). DOE and ERDA sponsored bibliographies on dawsonite-bearing oil shale (U.S. Energy Research and Development Administration, 1977; Farris and Leland, 1978; Farris and Mains, 1978; George and Jackson, 1984) and on the recovery of alumina from coal wastes (Burnet and others, 1983, 1984).

ERDA shared with the Aluminum Company of America a $\$ 5$ million contract to investigate the technical feasibility of the carbothermic reduction of alumina-silica ores (Energy Research Digest, 1977; Russell, 1981, p. 207). The direct-reduction process was designed to produce an aluminum-silicon alloy, ferrosilicon, and carbon monoxide. This process has serious problems, and, before it can be used commercially, appropriate refining technology must be developed.

ERDA and DOE financed research at the Ames Laboratory, Energy and Minerals Resources Research Institute, Iowa State University, on the extraction of alumina from coal ash that resulted in several reports (Cavin, 1974; Chou, 1976; Chou and others, 1976; Murtha and Burnet, 1976, 1978, 1979; Burnet, 1977; Burnet and others, 1977, 1983, 1984; Wijatno, 1977) described in the section titled "Investigations by U.S. Colleges and Universities.”

\section{U.S. ENVIRONMENTAL PROTECTION AGENCY}

The U.S. Environmental Protection Agency (EPA) supported research on the recovery of alumina from fly ash by the sodium hydroxide-sodium carbonate leaching method. The research supported by this program included work by Ray and Parker (1977), who studied fly ash from coal-fired powerplants, and Lawrence and Coalgate (1973), who evaluated the recovery of alumina from fly ash.

\section{U.S. ATOMIC ENERGY COMMISSION}

In the 1950 's, the search for uranium resources led to considerable interest in aluminum phosphate, which commonly contains a trace amount of uranium. The objective of much of this work was to find methods of recovering uranium, alumina, and phosphate as coproducts (Mining World, 1953). The U.S. Atomic Energy Commission (AEC) investigated the uranium and aluminum content of the leached zone overlying the phosphate deposits in Florida (Mining World, 1953). Phosphate, uranium oxide, and alumina were successfully recovered in a pilot plant set up by the AEC in cooperation with the 
International Minerals and Chemical Corporation (Mining World, 1953; Dugger and others, 1955). Work by the AEC resulted in four U.S. patents for extracting alumina from aluminous phosphate rock (Piros, 1956; McCullough, 1959; McCullough and Adams, 1959; Oberg and Le Baron, 1959). The discovery of roll uranium deposits (Shawe, 1956) diminished the interest in recovering uranium and alumina from U.S. phosphate deposits.

\section{U.S. NATIONAL BUREAU OF STANDARDS}

The U.S. National Bureau of Standards (NBS) conducted research, including bench tests and the operation of a small pilot plant, on extracting alumina from Georgia kaolin by a lime-sinter process (Flint and others, 1946). The sinter was prepared by annealing a fired mixture of kaolin and limestone. Alumina was extracted with a solution containing about $200 \mathrm{~g}$ of $\mathrm{Na}_{2} \mathrm{CO}_{3}$ and $150 \mathrm{~g}$ of $\mathrm{NaCl}$ per liter. The extracted solution contained 70-80 g of $\mathrm{Al}_{2} \mathrm{O}_{3}$ and 1-2 $\mathrm{g}$ of $\mathrm{SiO}_{2}$ per liter. After the extract was boiled with a charge of synthetic sodalite, the silica content was reduced to 0.1 percent or less of the alumina content. Alumina was precipitated by passing carbon dioxide into the desilicated solution. The NBS also conducted pilot-plant investigations on the recovery of alumina from clay by the hydrochloric acid leach process (Hoffman and others, 1946).

\section{TENNESSEE VALLEY AUTHORITY}

The Tennessee Valley Authority (TVA) operated an experimental plant to extract alumina from clay and evaluated western Tennessee resources of high-alumina clay as described above in the section titled "U.S. Research During World War II." The TVA also investigated the extraction of alumina from aluminous phosphate rock (Hignett and others, 1957).

\section{INVESTIGATIONS BY COMPANIES}

\section{ALUMINUM COMPANY OF AMERICA}

The Aluminum Company of America (Alcoa) has had a long history of research on the nonbauxite sources of alumina, which has been discussed by Edwards and others (1930). In 1942, Alcoa was the first company to use its combination process on Arkansas bauxite; it involved the extraction of alumina from high-silica bauxite and kaolin after the alumina had been extracted from the gibbsite fraction of the ore. The combination process consisted of sintering and leaching the high-silica red mud discarded from the Bayer process (Edwards, 1949). The red mud was sintered with limestone and soda ash. The sinter was leached with a caustic soda solution, which dissolved most of the alumina but only a very small proportion of the silica. The leach solution was included with the next cycle of bauxite in the Bayer process. The combination process made possible the economic extraction of 85-90 percent of the alumina from the high-silica bauxites in Arkansas.

Much research has been done on obtaining aluminum chloride directly from nonbauxite materials for reduction to aluminum (Landsberg, 1983). Alcoa and the Atlantic Richfield Company (Arco) agreed in 1983 to develop a method for making aluminum chloride from kaolin (Aluminum Company of America, 1984). The two companies jointly operated a pilot plant at Arco's research and development facility in Tucson, Ariz.

Alcoa's other activities related to obtaining alumina from nonbauxite sources included purchase of a 3,238-ha tract in the Laramie Range, Wyo., containing anorthosite (Rocky Mountain News, 1972) and research on the recovery of alumina from Wyoming anorthosite by a hydrothermal alkaline process (Hittner, 1981). According to Hamer and others (1978, p. 99), during the 1970's, Alcoa workers (Hudson and Swansiger, 1976; Hudson and others, 1977) researched the hydrochemical method proposed by Ponomarev and Sazhin (1959) for the extraction of alumina from high-silica ores.

Alcoa patented a carbothermic method of producing aluminum-silicon alloys (Cochran and others, 1977; Cochran, 1980). As mentioned above in the U.S. Department of Energy section, Alcoa and ERDA jointly funded a $\$ 5$ million research program in 1977 to make an aluminum-silicon alloy by carbothermic reduction (Energy Research Digest, 1977; Russell, 1981, p. 207).

Alcoa operated a pilot plant to investigate the extraction of alumina from coal waste (Beizer, 1974). In other work, both the lime-soda sinter process and a hydrochloric acid process were tested on coal-washing rejects and coal ash (Goodboy, 1976; Hudson, 1977). Hudson (1977, p. 82) concluded that alumina might be recovered economically from coal-washing rejects if (1) the rejects contained energy of approximately $9,304 \mathrm{~kJ} / \mathrm{kg}$, (2) the ash was approximately 30 percent alumina, and (3) the rejects could be obtained at no cost. Furthermore, the rejects would have to be adjacent to supplies of limestone and, perhaps, a source of high-alumina clay. The ranges in composition of coal-washing rejects investigated by Hudson (1977) are listed in table 15.

Workers in Alcoa laboratories also researched a hydrothermal alkaline process to extract alumina from anthracite coal waste near Shamokin, Pa. (Hsieh, 1981). This work was performed under a contract from the Appalachian Regional Commission.

Alcoa was one of the cooperating companies in the USBM miniplant program. 
TABLE 15.-Ranges in composition (in weight percent) of coalwashing rejects in Kentucky and Pennsylvania [Modified from Hudson (1977, table 2)]

\begin{tabular}{|c|c|c|c|}
\hline & $\begin{array}{l}\text { Western } \\
\text { Kentucky }\end{array}$ & $\begin{array}{c}\text { Eastern } \\
\text { Kentucky }\end{array}$ & $\begin{array}{c}\text { Western } \\
\text { Pennsylvania }\end{array}$ \\
\hline \multicolumn{4}{|c|}{ Coal-washing rejects } \\
\hline $\begin{array}{l}\text { Energy, in kJ/kg...... } \\
\text { Ash } \ldots \ldots \ldots \ldots \ldots \ldots \ldots \ldots \\
\text { S. . . . }\end{array}$ & $\begin{array}{c}8,490-20,700 \\
38-68 \\
3.0-13.8\end{array}$ & $\begin{array}{c}2,675-21,400 \\
36-82 \\
0.3-5.0\end{array}$ & $\begin{array}{c}2,908-18,143 \\
44-74 \\
0.6-4.3\end{array}$ \\
\hline \multicolumn{4}{|c|}{ Ash composition } \\
\hline 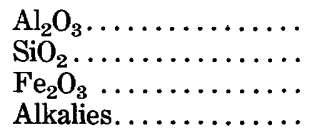 & $\begin{array}{r}10.5-20.8 \\
34.7-60.9 \\
9.0-34.0 \\
4.4-13.8\end{array}$ & $\begin{array}{c}15.0-23.4 \\
48.2-66.7 \\
3.7-14.0 \\
4.3-8.1\end{array}$ & $\begin{array}{c}19.3-27.8 \\
51.7-64.1 \\
3.4-17.0 \\
2.9-9.4\end{array}$ \\
\hline
\end{tabular}

\section{ANACONDA ALUMINUM COMPANY-ATLANTIC} RICHFIELD COMPANY

The Anaconda Aluminum Company patented a hydrochloric acid leaching process to recover alumina from kaolin (Holderreed and Sullivan, 1960; Laist, 1960a, b); it is similar to the process considered most promising by the National Materials Advisory Board (1970). Anaconda operated a pilot plant at Butte, Mont., that processed 5 metric tons a day in 1963. The first kaolin that Anaconda investigated intensively was from Latah County, Idaho (American Metal Market, 1963). This kaolin contained 26-27 percent alumina (Mining Engineering, 1963). Anaconda shifted its search to Georgia in order to obtain kaolin that had a higher alumina content. Anaconda and the Thiel Kaolin Company evaluated kaolin from Glasscock, McDuffie, and Warren Counties, Ga. (Georgia Mineral Newsletter, 1963), and shipped kaolin from Georgia to Butte for pilot-plant testing (Engineering and Mining Journal, 1963). Anaconda announced that a plant capable of producing significant quantities of alumina from kaolin was to be built in Georgia (Mining Journal, 1965). However, no such plant was ever constructed.

Anaconda was an original cooperator in the USBM miniplant program beginning in 1974. The Atlantic Richfield Company later bought Anaconda.

\section{KAISER ALUMINUM AND CHEMICAL CORPORATION}

Kaiser Aluminum and Chemical Corporation and its affiliate, Kaiser Engineers Corporation, constructed and operated the two USBM miniplants (Bengston and others, 1981; Barclay, 1984, p. 167) discussed above in the section titled "Miniplant Studies." Kaiser also investigated the extraction of alumina from kaolin by a hydrochloric acid process (Sawyer and Turner, 1985, p. 9-10) and investigated the extraction of alumina from aluminous phosphate resources (Porter, 1957, 1959). The Electric Power Research Institute (EPRI) awarded Kaiser a contract to study the recovery of alumina and other materials from coal fly ash by a hydrochloric acid process developed for the EPRI by DOE's Oak Ridge National Laboratory (Chemical Engineering, 1984; Baumgardner and Hough, 1985, p. 152). Kaiser estimated that $28,000-87,000$ metric tons of alumina could be obtained from each million metric tons of coal ash processed (Kaiser Engineers Corporation, 1986, v. 1, p. 4-1). Kaiser obtained a patent to form sodium dawsonite from the effluent of the Bayer alumina extraction process (Roberson and others, 1977).

\section{REYNOLDS METALS COMPANY}

The Reynolds Metals Company investigated the extraction of alumina from clay by a nitric acid process, as indicated by U.S. patents (Brown and Hrishikesan, 1966; Kelly and Bruen, 1971; Wise, 1971; Royce and Drown, 1974; Bruen and Kelly, 1975), and also did considerable research on the extraction of alumina from nonbauxite materials by an alkaline process (Kamlet, 1960; Brown, 1966) and a carbothermic process (Kibby, 1977). Reynolds also participated in the USBM miniplant program.

\section{OLIN MATHIESON CHEMICAL CORPORATION}

The Olin Mathieson Chemical Corporation developed a process for purifying aluminum sulfate that could be applied to the extraction of alumina from common clays or coal wastes (Light Metal Age, 1961; Higbie and others, 1963). The process involved the following steps: (1) leaching clay with sulfuric acid; (2) letting iron and aluminum sulfate crystallize and filtering out the large crystals; and (3) thermally decomposing aluminum sulfate crystals to form alumina and sulfur trioxide for making sulfuric acid.

Olin's affiliate Kalunite, Inc., developed the Kalunite process for treating alunite to produce alumina and potassium sulfate (Fleischer, 1944, p. 267). The process was used in Salt Lake City, Utah, during World War II as described above in the section titled "U.S. Research During World War II."

\section{ALUMINIUM PECHINEY}

Aluminium Pechiney investigated several techniques for the extraction of alumina from nonbauxite materials. The most advanced research was on the $\mathrm{H}+$ process (Bliss, 1976; Cohen and Mercier, 1976; Cohen and Adjemian, 1978a, b), which utilizes a two-stage acid attack. Sulfuric acid dissolves aluminum from the raw material. Impure aluminum sulfate is precipitated and then is converted to aluminum chloride hexahydrate by treatment with hydrochloric acid. The aluminum chloride 
hexahydrate is decomposed to alumina, and the hydrochloric acid is recycled.

Pechiney tested the $\mathrm{H}+$ process in the laboratory beginning in 1964 and in a small pilot plant beginning in 1968. In 1976, Pechiney cooperated with Alcan in the construction of a plant near Marseilles, France, having the capacity to produce 15-20 metric tons of alumina per day (Cohen and Mercier, 1976, p. 16). Shale associated with coal in France and kaolin from Georgia were tested in the plant. The process is suitable for use on several different aluminous materials, including clay, shale, and coal-mine waste, but not on those that contain appreciable quantities of alkalies, such as anorthosite. Although the $\mathrm{H}+$ process is effective in extracting alumina from some nonbauxite materials, it is not competitive with the Bayer process for extracting alumina from bauxite.

Pechiney and Alcan announced a feasibility study for a demonstration plant 10-20 times larger than the one at Marseilles (Barclay, 1984, p. 177). In 1982, the French Government nationalized Pechiney Ugine Kuhlmann, the parent company of Aluminium Pechiney, and plans for the demonstration plant were terminated.

As a partner with the Senegal Government, Pechiney has mined aluminous phosphate rock and has investigated the extraction of alumina from it (Mining Annual Review, 1988). Two French patents (Beja and Vincent, 1958; Jardin, 1959) may be products of Pechiney research on the extraction of alumina from aluminous phosphate rock.

Other research by Pechiney includes investigations of a process of continuous treatment of clay or shale by sulfuric acid (Maurel and Duhart, 1975) and a hydrochloric acid process (Maurel and Duhart, 1971)

\section{ALCAN INTERNATIONAL, LTD.}

Alcan International, Ltd. (Alcan), prepared several reports on the potential nonbauxite resources of alumina in Canada (Gummer, 1952; Bliss, 1976; Greig and Adams, 1977). As noted above, Alcan participated with Aluminium Pechiney in the construction of a pilot plant for extracting 15-20 metric tons of alumina per day from nonbauxite materials by the $\mathrm{H}+$ process (Cohen and Mercier, 1976). Alcan also investigated the hydrochloric acid process for extracting alumina from nonbauxite materials (Dewing and others, 1978). Alcan participated in the USBM miniplant program.

\section{TOTH ALUMINUM CORPORATION}

In 1967, Charles Toth applied for the first U.S. patent $(3,615,359)$ for the Toth process (Toth, 1969; Engineering and Mining Journal, 1973). Toth received other patents, including one in 1975 (Toth, 1975). The process consists of chlorination of calcined kaolin with recycled chlorine to form aluminum trichloride, which is reduced by manganese powder at about $230^{\circ} \mathrm{C}$ to aluminum powder. Iron is removed as a sandlike mixture in the form of ferric chloride and ferro-aluminum compounds, and the byproduct manganese dichloride is decomposed by an oxidation-reduction method into manganese metal powder and chlorine, which are recycled (Engineering and Mining Journal, 1973). U.S. patents obtained by the Toth Aluminum Corporation include those by Lippman and others (1976), Nemecz and others (1976a, b), and Lippman and Sebenik (1978). By 1984, the Toth Aluminum Corporation had constructed a carbochlorination plant at Vacherie, La., to recover aluminum from kaolin (Baumgardner and Hough, 1984, p. 142, 1985, p. 152; McCawley and Stephenson, 1984, p. 84).

\section{NORTH AMERICAN COAL CORPORATION}

The first effort in the United States to recover an aluminous product from shaly coal-mine waste was made by the North American Coal Corporation in cooperation with the Strategic Materials Corporation (Mining Journal, 1959). They built a pilot plant at Powhatan Point, Ohio, to extract aluminum and aluminum sulfate from shaly roof rock removed in the mining of the Pittsburgh coal bed. This plant used a sulfuric acid process and had an annual capacity for treating about 40,000 metric tons of shale, but it produced only a small quantity of aluminum sulfate in 1962 (Wilmot and others, 1960, p. 239; Higbie and others, 1963, p. 291). Extraction was not profitable, and the plant was dismantled (American Metal Market, 1964; Mining Journal, 1964).

\section{ALLIED CHEMICAL CORPORATION}

The Allied Chemical Corporation did considerable research on the extraction of alumina from clay and other nonbauxite materials, as is indicated by several U.S. patents for methods devised by Amano and Taylor (1968), Gerry and others (1968), Kelly and Yodis (1968), and Yodis and Schnoor (1968).

\section{ARTHUR D. LITTLE, INC.}

Arthur D. Little, Inc., patented several methods for extracting alumina from nonbauxite materials by using the nitric acid process. The patented methods were devised by George and Stone (1965), Beutner and Huska (1971), Flood (1971), Hyde and Margolin (1971), Huska and others (1972), Huska and Meissner (1974), and Margolin and Hyde (1974).

\section{KENNECOTT COPPER CORPORATION}

The Kennecott Copper Corporation obtained two U.S. patents relating to the recovery of alumina from copper 
leach solution (Spedden and Schellinger, 1969a, b). One patent was for removing multivalent impurities from the solution, and the other patent was for producing highpurity alumina.

\section{ALUMET}

Alumet is a partnership of National Steel Corporation, Southwire Company, and Earth Sciences, Inc. Since 1971, Alumet has evaluated the recovery of alumina from alunite. Pure alunite, $\mathrm{KAl}_{3}\left(\mathrm{SO}_{4}\right)_{2}(\mathrm{OH})_{6}$, is 37 percent $\mathrm{Al}_{2} \mathrm{O}_{3}, 38.6$ percent $\mathrm{SO}_{4}, 11.4$ percent $\mathrm{K}_{2} \mathrm{O}$, and 13.0 percent $\mathrm{H}_{2} \mathrm{O}$. A preliminary evaluation indicated that more than 100 million metric tons of rock in the Wah Wah Mountains, Utah, contained more than 35-40 percent alunite (Walker and Stevens, 1974). A pilot plant was constructed in 1973 near Golden, Colo., to test the recovery of alumina from alunite by roasting and leaching the alunite ore to remove potassium sulfate and then using a modified Bayer method to recover cell-grade alumina. Further information can be obtained from reports by the National Research Council (1979) and Barclay (1984, p. 183-186).

\section{OTHER COMPANIES}

Companies that did not participate in the USBM miniplant program described above but that have done research pertinent to the recovery of alumina from nonbauxite materials can be identified from the U.S. patents issued, as follows: (1) Phillips Petroleum Company (Arnold, 1945); (2) Kerr-McGee Corporation (Rado, 1981); (3) the Public Service Company of Albuquerque, N. Mex. (Reynolds and Williams, 1981); (4) Waldo Foundry of Bridgeport, Conn. (Gooch, 1896); (5) Monolith Portland Midwest Company (Spence, 1961); and (6) several German companies (Specketer and others, 1924; Marburg, 1930; Jonas and others, 1931; Messner, 1976). Houdry Process Corporation was granted a patent (Milliken, 1957) for a process to recover alumina from aluminum phosphates. Other companies are mentioned below in the sections on alumina extraction research done in different countries.

\section{INVESTIGATIONS BY U.S. COLLEGES AND UNIVERSITIES}

The Mining Experiment Station and State Electrometallurgical Research Laboratories of Washington State College (now University) investigated the recovery of alumina from high-alumina clay in the 1930's (Parkman, $1935)$ and early 1940 's. Woody (1943) prepared a bibliography on the extraction of alumina from clay. March $(1943 a, b)$ worked on the beneficiation of residual clays to upgrade the alumina content and a method of producing alumina from kaolin by sulfate leaching. Redlich and others (1946) investigated the recovery of alumina from clays in the Pacific Northwest by a sulfurous acid leaching process.

The extraction of alumina from high-alumina clays in Pennsylvania was investigated by the Pennsylvania State University (Sun and others, 1967). The extraction from clays was either by sulfuric acid or gaseous sulfur trioxide. Iron was removed by selective leaching of clay by hydrochloric acid or by electrolysis of the aluminum sulfate leach liquor. Fetterman (1961) and Fetterman and Sun (1962) investigated the extraction of alumina from diaspore clays by an ammonium sulfate process. The Pennsylvania State University's Coal Research Section released the results of literature surveys by Spicer (1971) on the uses of Pennsylvania anthracite waste and by Sun and others (1971) on chemical elements in anthracite waste. These surveys include information on alumina extraction from coal waste.

The Mining and Mineral Resource Research Institute of the University of Utah used grants from the USBM to investigate three methods of extracting alumina from coal waste (Sohn, 1983). The methods were the lime-soda sinter process, the carbothermic reduction of alumina to aluminum nitride, and the separation of alumina by the volatilization of silica. The waste material investigated came from the York Canyon coal mine, New Mexico. This material, which included both overburden and waste from the coal preparation plant, consisted of coal, quartz, muscovite, kaolinite, feldspar, pyrite, and other minor constituents. The preparation plant waste contained 22.8 percent alumina, and the overburden contained 17.9 percent alumina.

The Engineering Experiment Station of Georgia Institute of Technology investigated raw materials containing aluminum and methods of extracting alumina from kaolin (Ward and others, 1972; Husted, 1977; Ward and Husted, 1977). Husted (1974) reviewed the potential nonbauxite resources of alumina in the United States.

In the 1970's, workers at the Ames Laboratory at Iowa State University studied three processes for recovering alumina from fly ash from which as much as 85 percent of the iron oxide had been removed by magnetic separation; the processes were lime sinter, hydrochemical, and hightemperature chlorination (Burnet and others, 1977, p. 83). Cavin (1974) extracted alumina from the nonmagnetic fraction of powerplant fly ash by first sintering it with limestone, then leaching it with sulfuric acid. Other research was described by Chou (1976), Chou and others (1976), Murtha and Burnet (1976, 1978, 1979), Burnet (1977), and Wijatno (1977). Burnet and others (1983, 1984) prepared a bibliography on the recovery of metals from coal ash. Goodwin (1978) used magnetic separation and the method described by Chou and others (1976) for sintering fly ash with limestone, then leaching with a 
$\mathrm{Na}_{2} \mathrm{CO}_{3}$ solution. Goodwin (1978) estimated that this method would recover 98 percent of the iron, 98 percent of the alumina, and 85 percent of the calcium silicate from the fly ash.

Research on alumina extraction from coal waste has been done at the Coal Research Bureau of West Virginia University (Condry, 1976; Akers and others, 1978; Coalgate, undated) and the Institute for Mining and Minerals Research, University of Kentucky (Robl and Bland, 1977).

\section{INVESTIGATIONS OF U.S. DAWSONITE}

Information on dawsonite in oil shale of the Green River Formation can be found in publications of the Colorado School of Mines (CSM), the American Institute of Mining, Metallurgical, and Petroleum Engineers (AIME), and the Rocky Mountain Association of Geologists (RMAG). CSM, in cooperation with the Colorado School Research Foundation, Inc., and the Laramie Energy Technology Center, sponsored 18 symposia on oil shale. Although the primary subject was the distribution of oil in the oil shale, each symposium volume has several papers describing dawsonite and nahcolite in the shale (Colorado School of Mines, 1964, 1965, 1966, 1967, 1968; Gary, 1970, 1974, 1975, 1976, 1977, 1978, 1979, $1980,1981,1982,1983,1984,1985)$. More information on dawsonite can be found in various bibliographies (Mullens, 1973; Chronic and Matsushita, 1974; U.S. Energy Research and Development Administration, 1977; Farris and Leland, 1978; Farris and Mains, 1978; George and Jackson, 1984).

The USBM issued a contract to the Harrison-Western Corporation for drilling a mine shaft having a 2.4-m diameter at a site known as Horse Draw in the Piceance Creek basin, $37 \mathrm{~km}$ southwest of Meeker, Colo. (Cox, 1979). The Multi Minerals Corporation, under an agreement with the USBM, developed the mine (Cole and others, 1982). The purpose of the shaft and mine was to develop new mining techniques, to collect mine safety and environmental data, and to provide large samples of oil shale for research and process testing. A 100-metricton sample from the $640-\mathrm{m}$ level contained about 12 percent dawsonite, which is equivalent to about 4 percent recoverable alumina.

The DOE Laramie (Wyo.) Energy Technology Center, formerly the USBM Laramie Energy Research Center until 1975 and the ERDA Laramie Energy Research Center until 1977, has done a great deal of work on dawsonite resources and the recovery of alumina from dawsonite. The first published report on the large resources of dawsonite in the Green River Formation was by Smith and Milton (1966). Stanfield and others (1957) presented information on the stratigraphic units that contain dawsonite. Smith and Young (1969, 1975), Young and Smith (1970), and Robb and Smith (1974) analyzed dawsonite and nahcolite and determined their content in the oil shale. Young and others (1975) investigated the carbonate minerals, including dawsonite, in the oil shale because the thermal activity of carbonates is important when oil shale is retorted. Trudell and others (1970) reported on the distribution of dawsonite in the Piceance Creek basin, and the U.S. Bureau of Mines (1972a, b) made economic studies on the recovery of oil, nahcolite, and dawsonite from shale. Smith and others (1972) devised a method of estimating nahcolite and dawsonite in oil shale from the oil-yield data. Huggins and others (1973) evaluated methods of determining amounts of dawsonite and nahcolite in oil shale. Beard and others (1974) estimated the tonnage of nahcolite and dawsonite in the Piceance Creek basin to be 29 billion and 19 million metric tons, respectively. Robb and others (1978) investigated the mineral and hydrocarbon distributions across part of the Green River Formation in the Piceance Creek basin. Johnson and others (1977) determined potential oil yields and dawsonite, nordstrandite, and nahcolite contents of oil shale. Beard and Smith (1976) outlined a plan for the in-place recovery of dawsonite and other mineral products from the Saline zone in the Piceance Creek basin. Asai and others (1983) and White and others (1985) investigated the extraction of alumina from dawsonite. Jackson and others (1972) found ways of synthesizing dawsonite. Ferrante and others (1976) investigated the thermodynamic properties of synthetic dawsonite.

The mineralogy and properties of dawsonite have been investigated by Frueh and Golightly (1967), Estep and Karr (1968), Müller-Vonmoos and Bach (1969), Harris and others (1971), Tomilov and others (1971), Jackson and others (1972), and Huggins and Green (1973). Synthetic dawsonite has been made by the decomposition of sodium aluminate solutions by bubbling carbon dioxide into the sodium aluminate solution containing carbonate ions (Cada and others, 1972). Dawsonite has also been made synthetically in Japan (Kwon and others, 1971), France (Besson and others, 1973), Germany (Bader, 1938; Bader and Esch, 1944), and the United States (Jackson and others, 1972). Kim and Ishikawa (1974) investigated the changes in properties of synthetic dawsonite caused by thermal treatments. A U.S. patent has been issued for a process to form sodium dawsonite as a byproduct of the cleanup of effluent from a Bayer alumina extraction plant (Roberson and others, 1977); the dawsonite would be recycled to produce additional alumina.

The Superior Oil Company tested a process to produce nahcolite, oil, alumina (from dawsonite), and soda ash from oil shale (Weichman, 1974a, b, 1976). Nahcolite, 
more friable than the host shale, was to be removed as the fine material after crushing. Oil was to be recovered by retorting the oil shale, and the alumina and soda ash were to be recovered by leaching of the retorted shale followed by selective precipitation. The Oil Shale Corporation (TOSCO) also devised a process for recovering alumina from dawsonite (Haas and Atwood, 1975). The following list of U.S. patents gives an indication of the many studies that were made on the recovery of alumina from dawsonite in oil shale: (1) TOSCO patented methods for recovering alumina and sodium aluminate from oil shale (Hall and Haas, 1970; Haas, 1975); (2) Shell Oil Company patented methods for recovering oil and dawsonite from oil shale (Prats, 1970; Templeton, 1971; Papadopoulos and Ueber, 1972; Closmann and Suman, 1974), and Shell International patented a process for recovering alumina (Middelhoek and others, 1977); (3) Sinclair Research, Inc., patented a process for recovering aluminum from retorted shale (Van Nordstrand, 1968); (4) Marathon Oil Company patented a method of extracting dawsonite and nahcolite from crushed oil shale (Tackett, 1970); and (5) MacMillan and Jackson (1972) patented an alkaline method of extracting alumina from oil shale.

\section{INVESTIGATIONS IN OTHER COUNTRIES}

\section{ARGENTINA}

In 1954, Argentina was reported to have plans to build a plant at Comodoro Rivadavia, Chubut Province, that would have cost approximately $\$ 25$ million (Engineering and Mining Journal, 1954). This plant was to recover alumina from clay from Neuquén Province, but it was never built.

Later, plans were made for the extraction of alumina from lateritic clays in Misiones Province (U.S. Bureau of Mines, 1965). An Argentine firm obtained a license to use the Australian Commonwealth Scientific and Industrial Research Organization (CSIRO) process for the extraction of alumina from clays that was developed in 1962 (Scott, 1962). No plant was built (Kimbell, 1967, p. 148).

The Mining Annual Review (1971) reported that the Alto Parana Mining Company did pilot-plant tests on extracting alumina from laterite in Misiones Province. Apparently that work never led to a commercial plant.

\section{AUSTRALIA}

The Australian Commonwealth Scientific and Industrial Research Organization (CSIRO) developed a twostage process for the recovery of alumina from clay or low-grade bauxite ores that are high in silica or iron (Scott, 1962). The process involved digestion of the ore by acid at $180^{\circ} \mathrm{C}$, modification of the liquor at $130{ }^{\circ} \mathrm{C}$ by dissolution of more alumina to make the liquor slightly basic, reduction of iron oxide by sulfur dioxide, hydrolysis at about $200^{\circ} \mathrm{C}$ to precipitate basic aluminum sulfate crystals, calcination of the residual sulfur, and absorption of the sulfurous gases to form acid for reuse. Research on the extraction of alumina from clay ceased in the late 1960's because Australia's large bauxite deposits were developed; the total bauxite resources of Australia are presently estimated to be 6 billion- 8 billion metric tons (Patterson and others, 1986, p. B128).

\section{CANADA}

During World War II, Canada, like other bauxitedeficient, aluminum-producing countries, was concerned about possible substitutes for bauxite. As reported by Gummer (1952, p. 605), "At one time during the last war, Aluminium Limited [which became Alcan] and its affiliates fielded a large group of geologists, mineralogists, engineers, and chemists, who applied their combined efforts to new untried sources of the metal." Canadian governmental agencies, provincial bureaus of mines and geological surveys, and corporations such as Aluminium Company of Canada, Limited (Alcan), and the American Nepheline Corporation participated in the wartime effort. The rocks investigated included laterite, residual clay, sedimentary clay and shale, nepheline rocks, anorthosite, andalusite schist, muscovite schist, pyrophyllite schist, and alunite. According to Gummer (1952, p. 610), the results of this work could be summarized as follows:

The relation of alumina to other constituents of the ore will be important; alumina can be recovered from some compounds more easily than from others. A rock with medium alumina and high alkalies (such as the nepheline rocks) might be preferable to one with high alumina and low alkalies. On the basis of our present knowledge of aluminum-bearing rocks other than bauxites, the most likely Canadian sources of aluminum in a case of emergency or radically modified economics appear to be anorthosite and nepheline syenite. Both these rocks have been successfully processed on the pilot-plant scale. There are enormous bodies of both rocks in Canada, and anorthosite is one of the most abundant types adjacent to the great Arvida power and production centre.

Clays are treatable by more than one method, and alumina can be recovered from them, but the results of our surveys show that they cannot have the same potential importance for the aluminum industry of Canada as they appear to have for that of other countries; as a consequence, their utilization has been given less emphasis in process development studies.

In the 1970's, the Canadian Centre for Mineral and Energy Technology (CANMET) did considerable research on the recovery of alumina from nonbauxite materials. The following processes applied to anorthosite were researched: (1) alkali sinter (Winer and Quon, 1979); (2) hydrochemical (Hamer and others, 1978); (3) acid leaching of melted and quenched anorthosite (Hamer and others, 1978); (4) acid extraction (Hamer and 
others, 1978); and (5) lime sinter (Quon, 1976; Ripley, 1976). In tests of the sulfuric and hydrochloric acid processes, 90 percent of the alumina was recovered from Saskatchewan clays (Hamer and others, 1978). A hydrochloric acid process applied to coal-mine wastes recovered 90 percent of the alumina (Hamer and others, 1978). CANMET has investigated the recovery of alumina from coal waste in the Hat Creek coal district, British Columbia; the methods studied were hydrochloric acid leaching of ash (Hamer, 1977), hydrochloric acid and hydrofluoric acid leaching of ash (Ripley, 1979a), and a modified lime-sinter process applied to coal waste (Ripley, 1979b).

\section{CZECHOSLOVAKIA}

During World War II, an experimental plant at Stramberk used a lime-sinter method to recover hydrated alumina from coal ash (Tomka, 1974, p. 196). The plant had a production capacity of about 5,000 metric tons of hydrated alumina per year and used ash from the Ostrava powerplant. The ash contained about 20 percent $\mathrm{Al}_{2} \mathrm{O}_{3}$ and 28 percent $\mathrm{SiO}_{2}$. The plant was expensive and was closed when low-grade Hungarian bauxite became available (Tomka, 1974).

Because Czechoslovakia has no bauxite, research on nonbauxite sources of alumina has continued. Hubacek and Svejda (1965) described how to produce portland cement and recover alumina from clay and coal ash after sintering the source material with limestone and then leaching with $\mathrm{Na}_{2} \mathrm{CO}_{3}$ solution.

\section{EGYP'T}

The Alexandria University, Egypt, supported the study of the extraction of alumina from kaolin by the hydrochloric acid method (Bakr and El-Abd, 1969). The Metallurgy Department, National Research Centre (Cairo), researched the extraction of alumina from kaolin by the lime-soda sintering process (Hussein and others, 1974). The kaolin tested was from Sabba, in northern Egypt, and Aswan, in southern Egypt. The Sabba kaolin contained 36.9 percent alumina and 44.0 percent silica, and the Aswan kaolin contained 27.4 percent alumina and 57.2 percent silica (Hussein and others, 1974, p. 85).

From 1966 to 1969, the Egyptian Geological Survey and the U.S.S.R. investigated the nepheline syenite of the Jabal Abū Khurūq area, Egypt. Metallurgical tests showed that alumina can be recovered from the nepheline syenite when it is mixed with Egyptian limestone; the process is technologically feasible and results in valuable byproducts - portland cement, soda, and potash (El Ramly, Dereniuk, and others, 1970).

Rehim (1974), of Alexandria University, also studied the alkali-sinter process for recovering alumina from the Jabal Abū Khurūq nepheline syenite. Hussein and others
(1974) researched lime sintering of the same rock. The sample tested by Hussein and others (1974, p. 97) contained the following major components: 21.6 percent $\mathrm{Al}_{2} \mathrm{O}_{3}, 55.2$ percent $\mathrm{SiO}_{2}, 5.1$ percent $\mathrm{Fe}_{2} \mathrm{O}_{3}, 10.1$ percent $\mathrm{Na}_{2} \mathrm{O}$, and 5.0 percent $\mathrm{K}_{2} \mathrm{O}$.

\section{FEDERAL REPUBLIC OF GERMANY}

A sulfurous acid process for extracting alumina from clay was attempted on a semicommercial scale in Germany in 1938 (Anderson, 1940, p. 275; Kramer, 1983, p. 2). The resulting alumina was too impure to be cell grade, and the Bayer process was used to reduce the impurities.

Phonolite was investigated as a source of alumina in Germany in 1939 (U.S. Bureau of Mines, 1939, p. 2). The method considered involved mixing ground phonolite with alkali and limestone, sintering the mixture at 1,200 ${ }^{\circ} \mathrm{C}$, and leaching with soda. The products of this method are potassium-sodium aluminate, from which alumina would be obtained, potassium and sodium carbonate, and calcium silicate used to make cement.

Several U.S. patents for alumina extraction methods were awarded to German companies during the period 1934 to 1941 (Staufer and Konopicky, 1934; Wiedbrauck and Büche, 1934, 1935; Fulda and others, 1935; Fulda, Wiedbrauck, and Büche, 1938, 1941; Büche and Ginsberg, 1941; Fulda, Wrigge, and Logemann, 1941). In 1955, the Vereinigte Aluminium-Werke A.-G. (VAW) obtained a British patent for a process to recover aluminum from coal fly ash (VAW, 1955). A German patent (Huber and Rohlfs, 1957) suggests that Chemische Werke Albert did some work on the recovery of alumina from aluminum phosphates. A U.S. patent for the extraction of alumina from nonbauxite materials was awarded to VAW (Belsky, 1974); leaching aluminum silicates with an aqueous solution of hydrochloric and fluosilicic acids eliminated the need for calcination of the ore. VAW surveyed potential nonbauxite aluminum resources (Bielfeldt and others, 1978; Belsky and others, 1981) and found large available quantities of coal wastes and kaolin. VAW investigated a hydrochloric acid process for extracting alumina from lignite-bearing kaolin (Belsky and others, 1981).

\section{GERMAN DEMOCRATIC REPUBLIC}

According to Belsky and others (1981, p. 102), VEB Elektro-Chemisches Kombinat operated experimental plants in the German Democratic Republic for several years after World War II; the plants tested a hydrochloric acid process for extracting alumina from clay.

\section{HUNGARY}

The Hungarian Ministry of Heavy Industry, the Institute of Energetics, and the Tatabanya coal mines coop- 
erated with Professor Grzymek of Poland in research on a self-disintegration process for recovering alumina from aluminum silicates (Gulyás and Vámos, 1976; Kapolyi and others, 1981). The Tatabanya coal mines operated a large pilot plant to test a modification of Professor Grzymek's process for the extraction of alumina from fly ash from powerplants (Gulyás and Vámos, 1976). The pilot-plant process involved sintering of the ash with limestone and the extraction of alumina with a $\mathrm{Na}_{2} \mathrm{CO}_{3}$ solution. The modified process requires less energy than the original but still produces 10 metric tons of portland cement for each metric ton of alumina. This modified process is patented in the United States (Kapolyi and others, 1980).

\section{ITALY}

When the supplies of potash from German and Alsatian mines were cut off during World War I, attempts were made to recover potash and aluminum chloride from leucite in Italy on a "semi-commercial scale" (Edwards and others, 1930, p. 57). The process first used was a hydrochloric acid method developed by Blanc (1931, p. 53). The leucite was ground in a plant at Sessa Aurunca, which is a few kilometers northwest of Naples. In 1931, a plant designed to extract potash and alumina from leucite by a nitric acid process was built at Civitavecchia by Aluminium Limited (Blanc, 1931, p. 56).

The Società Italiana Potassa (SIP) modified the Jourdan lime-sinter process to recover alumina from leucite at the Bagnoli plant in 1942-43 (Abbruzzese and Rinelli, 1981 , p. 24). The Jourdan process was patented in Italy in 1926 (Jourdan, 1926).

Interest in the extraction of alumina from Italian leucite developed again in the 1970's and 1980's, when considerable research was done (Cocco and others, 1978, 1981; Massacci, 1978; Abbruzzese and Rinelli, 1981; Massacci and others, 1981). Tests were made on the extraction of alumina from leucite by the alkali-sinter process (Landi, 1975), by the direct carbothermic process (Landi, 1981; Landi and others, 1984), and by a carbochlorination process (Bombara and Tanzi, 1984). According to World Mining (1980), Alumetal planned to build a plant to process leucite in Sardinia.

The extraction of alumina from coal fly ash at the Porto Vesme powerplant was investigated by the Institute of Mineral Processing in Rome (Abbruzzese, 1983). The ash contained only 13.8 percent alumina, but large quantities were available.

According to Hall (1978, p. A23), preliminary research has been undertaken to determine the feasibility of using alunite as a source of aluminum. However, commercial development seems unlikely in the near future.

\section{JAPAN}

During World War II, alumina was extracted from alunite, clay, shale, and aluminous phosphate rock in Japan (Sakamoto, 1951; Sato and others, 1956, p. 197). Only material that contained or could be upgraded by beneficiation to 30 percent or more alumina was used (table 1).

A process for extracting alumina from coal fly ash was patented shortly after the war (Hiku, 1947); the ash was sintered with limestone and a small amount of $\mathrm{NaCl}$ and was leached with sulfuric acid. Sulfuric acid processes were also studied by Funaki (1950) and Arimori (1952). More recent studies in Japan include (1) research at an experimental plant operated by the Mitsui Group to test the direct smelting of bauxite or aluminous clay with coke and chemicals (Mining Journal, 1981) and (2) research on a chloric acid process for extracting alumina from Japan's 1 billion metric tons of colloidal earth (high-alumina clay) and using the byproduct silica to make glass (Mining Journal, 1971).

\section{MEXICO}

Industria Penoles S.A. planned to use nepheline syenite as a source of alumina in Mexico. This company acquired the U.S.S.R.'s VAMI process for extracting alumina from nepheline syenite (Industrial Minerals, 1979a).

A process to extract alumina, aluminum sulfate, sulfuric acid, and potassium ammonium sulfate from alunite was developed on a laboratory scale at the University of Guanajuato (Hall, 1978, p. A20-A21). The plan to erect a full-scale plant at Salamanca, Guanajuato, to process alunite has been suspended.

\section{NORWAY}

A plant was built at Høyanger, Norway, in 1928 to recover alumina from anorthosite consisting predominantly of labradorite (U.S. Bureau of Mines, 1953, p. VII-8). In the Pedersen process used, the labradorite was mixed with limestone and coke in an electric furnace to produce a calcium aluminate-calcium silicate sinter. The sinter was then leached with sodium carbonate to put the alumina in solution as sodium aluminate. After removal of the insoluble residue, the alumina was precipitated by carbon dioxide. Iron was a byproduct.

During the 1970's, a research company called Anortal was set up by Norway's aluminum producers to investigate nonbauxite sources of aluminum (Industrial Minerals, 1979b). The work was primarily on anorthosite (apparently from the Vossestrand district), although Norway is one of the world's few producers of nepheline syenite. 
Kurtz (1978, p. 211) reported that two Norwegian aluminum companies, A/S Aardal og Sunndal Verk and Elkem Spigerverket, had constructed a pilot plant to test a new process for extracting alumina from anorthosite.

\section{PHILIPPINES}

The Philippines Bureau of Mines (1978) investigated the recovery of alumina from clay deposits on Batag Island, northern Samar. It was found that the pulp viscosity, calcining temperature, and leaching temperatures are the most critical factors controlling leaching of alumina from these clays. The test results showed the recovery of 72 percent of the alumina in clay as sodium aluminate compounds.

\section{POLAND}

Two processes for the recovery of alumina from nonbauxite raw material have been developed in Poland. One process, developed by Professor Grzymek (1976, 1978), is applied to fly ash or coal waste. It is based on an automatic disintegration of a sinter containing calcium aluminates and dicalcium silicate. The dust is mixed with water and sodium carbonate and undergoes a complicated series of chemical treatments including carbonization and water scrubbing to produce alumina and portland cement in the approximate ratio of 1:12. The other process, known as Professor Bretsznajder's process (Nowak, 1974), is an acid leach process. Sulfuric acid is added to aluminous material (clay or fly ash) and heated with high-pressure steam. Complete disintegration takes place in about 30 minutes.

Two experimental alumina plants were constructed in Poland (Kurtz, 1972, p. 222; 1976, p. 214). A plant between Glogów and Lubin was designed to process clay with acid. The other plant, near Kielce, tested production of alumina and portland cement by Professor Grzymek's process.

\section{ROMANIA}

Investigations were made in Romania of a process for the recovery of alumina and iron oxide from carbonaceous shale, kaolin, and powerplant coal fly ash (Sarbu and others, 1981). The process included sintering the aluminous material with $\mathrm{NaCl}$, quenching the sinter with water, and leaching the remaining sinter with hydrochloric acid.

\section{SOUTH AFRICA}

Several nonbauxite materials have been considered as potential sources of alumina in South Africa (McCulloch, 1967; Brabers, 1974). They include diaspore-bearing shale, several types of igneous rocks, muscovite clay, flint clay, and sericite. Pressure leaching of fly ash with an alkali solution has also been investigated (Adrian and McCulloch, 1966).

\section{SOUTH KOREA}

The South Korean Research Institute of Geoscience and Mineral Resources investigated the extraction of alumina from alunite (Cho and Son, 1978) and from a large anorthosite stock near Hadong (Professor Byung Koo Hyun, written commun., July 20, 1976). The South Korean National Industrial Research Institute studied the preparation of polyaluminum chlorides from anorthosite, kaolin, and alunite (Kim and Kim, 1969).

\section{SPAIN}

The aluminum company owned by the Spanish Government, Empresa Nacional del Aluminio, Madrid, and the Escuela Técnica Superior de Ingenieros de Minas, Oviedo, investigated the extraction of alumina from the Puentes de Garcia Rodriguez Tertiary clay in La Corũna and from Carboniferous coal-bearing slate in Asturias (Brime and others, 1978; Sancho, Iglesias, and others, 1981; Sancho, Verdeja, and others, 1981). Investigations of kaolin also were made by the Spanish universities (Galán Huertos and Martín-Vivaldi, 1973; Galán Huertos and Espinosa de los Monteros, 1974).

\section{SWEDEN}

A plant at Sundsvall, Sweden, erected to recover alumina from andalusite by the Pedersen process, produced about 8,000 metric tons per year of alumina from 1942 to 1947 (Bracewell, 1962, p. 54, 156; Barr, 1977, p. C64). In 1977, two of Sweden's largest mining groups, Boliden $\mathrm{AB}$ and Luossavaara-Kirunavaera $\mathrm{AB}$ (LKAB), formed a subsidiary for the purpose of developing the country's alum shale deposits (Industrial Minerals, 1977; Mining Engineering, 1977).

\section{TAIWAN}

The National Tsing Hua University, Taiwan, investigated the extraction of alumina from kaolin that had been calcined and then treated with hydrochloric acid (Lin and Chen, 1978).

\section{UNITED KINGDOM}

The resources and alumina extraction of nonbauxite material were investigated by the British Geological Survey, formerly known as the Institute of Geological Sciences (Varley, 1965; Allen and Charsley, 1968; Crocket, 1975; Highley, 1975, 1982; Read and Dean, 1978; Ridgway, 1982), by the Camborne School of Mines 
(Wills and Phillips, 1977; Phillips and Wills, 1979), and by the Warren Spring Laboratory (Christie and Derry, 1976). Some materials that have been considered as possible sources of alumina in the United Kingdom are listed in table 3. Other materials considered include coal waste, coal fly ash, mica-rich residue from china clay washings, and fly ash from refuse incineration.

\section{U.S.S.R.}

The first significant peacetime use of nonbauxite material for producing alumina was the use of nepheline syenite in the U.S.S.R. The material used was the tailings that remained after apatite, used in fertilizer, was extracted from nepheline syenite (Shabad, 1976a). Apatite mining began in 1931, and the syenite used was from the Khibiny pluton on the Kola Peninsula. The possibility of using nepheline syenite tailings as a source of alumina was demonstrated experimentally in 1932 . In 1939 , a concentrator was built, but it was not until after World War II that nepheline syenite was used as a source of alumina.

In 1949, the first nepheline syenite tailings were shipped from Khibiny to the Volkhov alumina plant 112 $\mathrm{km}$ east of Leningrad, and the technology was finally mastered in 1954 (Shabad, 1976a). The Volkhov alumina plant, which originally processed bauxite from the Boksitogorsk district, was converted to use nepheline syenite. Nepheline syenite was also used in the Pikalevo alumina plant commissioned in 1959 about $240 \mathrm{~km}$ southeast of Leningrad. According to Shabad (1976a), in 1976, the annual alumina production at Volkhov was 50,000 metric tons and that at Pikalevo was 300,000 metric tons. Stankovich (1978, table 2) estimated the annual capacities of these plants in 1976-80 as 130,000 metric tons of alumina for the Volkhov plant and 500,000 metric tons for the Pikalevo plant.

The Kandalaksha plant in the Murmansk region of the Kola Peninsula also processed nepheline syenite. Stankovich (1978, table 2) estimated its capacity to be 70,000 metric tons of alumina per year.

Two other plants for extracting alumina from nepheline syenite or similar material were designed (Shabad, 1976a, p. 228-229). A plant at Achinsk, which is about $150 \mathrm{~km}$ west of Krasnoyarsk, Siberia, has an annual capacity of 800,000 metric tons of alumina (Stankovich, 1978, table 2). It was to process nepheline syenite from Goryachegorsk, but a richer deposit at Belogorsk on the - Kiya-Shaltyr River $206 \mathrm{~km}$ southwest of Achinsk became the source of ore (Shabad, 1976a, p. 228). Apparently the plant at Achinsk was partly converted to bauxite and never reached its full capacity using nepheline syenite (Shabad, 1976b).
The second plant was in Armenia and was to be supplied with nepheline syenite from Tezhsar near Razdan. Construction of the plant in Armenia progressed slowly, and the plant may have been converted to processing imported bauxite before it was completed (Shabad, 1976b).

According to Stankovich (1978), the alumina output from at least three of the Soviet plants processing nepheline syenite was 700,000 metric tons in 1976 .

The process for extracting the alumina from nepheline syenite at the Volkhov plant, which is apparently the process used in the other Soviet plants processing nepheline syenite and similar raw materials, was described by Allen and Charsley (1968, p. 103-104). The nepheline tailings are finely ground with limestone in water to form a sludge. This sludge is dried and calcined at about $1,300{ }^{\circ} \mathrm{C}$ to produce a sinter consisting mainly of dicalcium silicate and aluminates of sodium and potassium. The sinter is ground to 40-50 mesh and treated with caustic soda solutions to leach out the alkali aluminates and to leave a residue that is called nepheline slurry. The solution containing the aluminates is treated with carbon dioxide to precipitate aluminum hydroxide, which is converted to alumina by calcining. Sodium and potassium are recovered from the solutions. The quality of the alumina from nepheline syenite is reported to be similar to that of the alumina extracted from bauxite; the principal impurities are 0.12 percent $\mathrm{SiO}_{2}, 0.31$ percent $\mathrm{Fe}_{2} \mathrm{O}_{3}$, and 0.37 percent $\mathrm{Na}_{2} \mathrm{O}$.

The nepheline slurry at the Volkhov plant contains solids consisting mainly of calcium silicate, some aluminum, iron, and sodium oxides, and traces of titanium and phosphorus oxides (Allen and Charsley, 1968, p. 104). To manufacture portland cement clinker, the slurry is mixed in the proportion of 45 parts (dry) with 49 parts ground limestone, 4 parts bauxite, and 2 parts pyrite clinker. After calcining, the cement clinker contained the following major components: 21.83 percent $\mathrm{SiO}_{2}, 64.95$ percent $\mathrm{CaO}, 4.97$ percent $\mathrm{Al}_{2} \mathrm{O}_{3}, 4.33$ percent $\mathrm{Fe}_{2} \mathrm{O}_{3}$, and 1.62 percent $\mathrm{MgO}$. Allen and Charsley (1968, p. 103) reported that, in 1955, 150,000 metric tons of nepheline concentrates were used to produce 40,000 metric tons of alumina, 30,000 metric tons of soda and potash, and 300,000 metric tons of portland cement.

In addition to nepheline syenite, alunite is also used as a source of alumina in the U.S.S.R. The deposits mined are in the Zaglik district near Kirovabad in Transcaucasia. The initial process for extracting alumina from alunite was designed by Georgiy V. Labutin (Shabad, $1976 \mathrm{a}$, p. 230) to yield 1 metric ton of alumina, 1.15 metric tons of sulfuric acid, and 0.2-0.235 metric ton of potassium sulfate from 6.6-6.7 metric tons of ore containing 50 percent alunite. In this process, the alunite ore is crushed, ground, and roasted to drive off water of 
crystallization (National Research Council, 1979, p. 128). Sulfates of potash and alumina are dissolved and selectively precipitated to recover alumina, potash, and sulfuric acid. The All Union Scientific-Research and Designing Institute for Aluminium, Manganese, and Electrode Industry (VAMI), Leningrad, modified the process and claimed to have attained 95-97 percent alumina recovery (Šmorgunenko and Vlasov, 1981). According to Shabad (1976a, p. 230), construction of the alunite processing plant at Kirovabad began in 1955; the plant reached 40 percent of capacity in 1969 and full capacity in 1973. In 1973 , the plant is reported to have produced 550,000 metric tons of sulfuric acid, about 200,000 metric tons of alumina, and 40,000 metric tons of potassium sulfate. Stankovich (1978) described other alumina plants processing alunite and estimated total Soviet alumina production from alunite as 650,000 metric tons in 1976 .

The U.S.S.R. has also investigated the alumina recovery from nonbauxite materials other than nepheline syenite and alunite. A pilot plant was operated from 1968 to 1972 at the Alimalyk metallurgical complex in Uzbekistan to test a lime-sinter process proposed in the 1950 's for extracting alumina from kaolin from the Angren district (Shabad, 1976a, p. 231). Cement was a byproduct.

In 1933 , a process for the extraction of alumina from ash of the Moscow basin coal was patented (Gusev and others, 1933). The extraction of alumina from coalwashing rejects by a nitric acid process was investigated by Korshunov and Shmuk (1957). The alumina content of the rejects was $30-35$ percent. Mine waste from the Ekibastuz coal field contained $22-30$ percent alumina, which was extracted by Sukhanova and Ponomarev (1969) by a sulfuric acid-ammonium sulfate process. In a pilot plant at Alma-Ata, 90 percent of the $\mathrm{Al}_{2} \mathrm{O}_{3}$ and 90 percent of the $\mathrm{Na}_{2} \mathrm{O}$ were recovered from coal fly ash sintered with $\mathrm{CaO}$ and $\mathrm{Na}_{2} \mathrm{CO}_{3}$ (Nurmagambetov and others, 1977).

The recovery of alumina from sillimanite in the Kyakhta district, near the Mongolian border south of Lake Baykal, was investigated during the 1950's by the Rare Metals Research Institute at Irkutsk (Varley, 1965, p. 92). The Kyakhta deposits are among the largest nonbauxite alumina resources in the U.S.S.R. (Varley, 1965). Sillimanite from the Kyakhta deposit was suggested in the late 1950's as a possible raw material for the Irkutsk alumina plant at Shelekhov, but the work probably did not go beyond the pilot-plant stage (Shabad, 1976a, p. 231).

Research on processes for recovering alumina from kyanite has been done by Shul'gin and others (1975). The Kola Branch of the Academy of Sciences of the U.S.S.R. recommended that kyanite concentrates from the Shuur- urta deposits on the Kola Peninsula be used for direct electrothermal reduction to aluminum-silicon alloys (Shabad, 1976a, p. 231).

\section{YUGOSLAVIA}

Paulin and others (1981), working at the Edvard Kardelj University, Ljubljana, Yugoslavia, conducted research on the chlorination of low-grade aluminous materials. Logomerac and Črnko (1981), working at the University of Zagreb, Sisak, investigated the recovery of rare-earth elements and alumina from leucite near Gnjilane, Kosovo, Yugoslavia.

\section{REFERENCES CITED}

Abbruzzese, C., 1983, Hydrochemical extraction of alumina from coal ash: Comité International pour l'Étude des Bauxites, de l'Alumine et de l'Aluminium Travaux, no. 18, p. 305-314.

Abbruzzese, C., and Rinelli, G., 1981, Leucite bearing rocks as an alternative source for alumina production in Italy: Comité International pour l'Étude des Bauxites, de l'Alumine et de l'Aluminium Travaux, no. 16 , p. 23-30.

Adams, F.D., and Barlow, A.E., 1910, Geology of the Haliburton and Bancroft areas, Province of Ontario: Canada Geological Survey Memoir 6, $419 \mathrm{p}$.

Adrian, A.B., and McCulloch, H.W., 1966, Pressure leaching of ores with particular reference to the upgrading of aluminate solutions. II, Alkaline pressure leaching of Sasol fly ash: South Africa Government Metallurgical Laboratory Report C.13/65, 13 p.

Aikawa, Nobuyuki, Yoshida, Masaru, and Ichikawa, Koichiro, 1972, Discovery of dawsonite and alumohydrocalcite from the Cretaceous Izumi Group in Osaka Prefecture, southwest Japan: Japanese Association of Mineralogists, Petrologists, and Economic Geologists Journal, v. 67 , no. 11, p. 370-385.

Akers, D.J., McMillan, B.G., and Leonard, J.W., 1978, Coal minerals bibliography, final report: U.S. National Technical Information Service [Report] FE-2692-5, $230 \mathrm{p}$.

Alexander, L.T., Hendricks, S.B., and Faust, G.T., 1942, Occurrence of gibbsite in some soil-forming materials: Soil Science Society of America Proceedings, 1941, v. 6, p. 52-57.

Allen, J.B., and Charsley, T.J., 1968, Nepheline-syenite and phonolite: London, Great Britain Institute of Geological Sciences, Mineral Resource Division, $169 \mathrm{p}$.

Allen, S.A., 1949, Bauxite investigations, Eufaula district, Barbour and Henry Counties, Ala.: U.S. Bureau of Mines Report of Investigations $4521,85 \mathrm{p}$.

Allen, V.T., 1952, Petrographic relations in some typical bauxite and diaspore deposits: Geological Society of America Bulletin, v. 63, no. 7 , p. $649-688$.

Allen, V.T., Loofbourow, J.S., Jr., and Nichols, R.L., 1951, The Hobart Butte high-alumina clay deposit, Lane County, Oregon: U.S. Geological Survey Circular 143, 11 p.

Altschuler, Z.S., Jaffe, E.B., and Cuttitta, Frank, 1956, The aluminum phosphate zone of the Bone Valley Formation, Florida, and its uranium deposits, in Page, L.R., Stocking, H.E., and Smith, H.B., comps., Contributions to the geology of uranium and thorium by the United States Geological Survey and Atomic Energy Commission for the United Nations International Conference on Peaceful Uses of Atomic Energy, Geneva, Switzerland, 1955: U.S. Geological Survey Professional Paper 300, p. 495-504. 
Aluminum Company of America, 1984, Alcoa annual report 1983: Pittsburgh, Pa., 45 p.

Amano, C.K., and Taylor, M.L., 1968, Selective extraction of alumina from bauxite with nitrogen peroxide and water at high temperature and pressure: U.S. Patent $3,387,921$, assigned to Allied Chemical Corporation, $3 \mathrm{p}$.

Amer, A.F., Krinstov, M.I., and Hanna, F.L., 1970, Assessment of the Egyptian clay deposits, in Studies on some mineral deposits of Egypt; Part III, Nepheline syenite project: Cairo, United Arab Republic Geological Survey, p. 209-218.

American Metal Market, 1963, Process evaluated on alumina from clay cost: American Metal Market, v. 70, no. 110, p. 16.

-1964, North American Coal [Corporation] drops alumina from clay project: American Metal Market, v. 71, no. 4, p. 11.

-1981, Gibbsite [Corporation of America] leases Va. tract for extraction of alumina: American Metal Market, v. 88 , no. 18 , p. 8 .

Ampian, S.G., 1967, Lime soda sinter process-Correlation of reaction products with extractability of alumina from anorthosite: U.S. Bureau of Mines Report of Investigations 6933, $44 \mathrm{p}$.

Anderson, A.T., Jr., 1968, Massif-type anorthosite-A widespread Precambrian igneous rock, in Isachsen, Y.W., ed., Origin of anorthosite and related rocks: New York State Museum and Science Service Memoir 18, p. 47-55.

Anderson, R.J., 1940, The German aluminium industry: Mining Magazine, v. 62 , p. 201-212, 274-284.

Apa, R.P., Grimmett, E.S., Keller, F.R., and McFee, J.N., 1982, Alumina extraction from anthracite culm with energy recovery: U.S. Bureau of Mines Open File Report 121-83, 86 p.

Aravamuthan, Veeraragava, and Sundaram, M., 1965, Extraction of alumina from Neyveli clay: Indian Industries, v. 9, no. 5, p. 21-23.

Archibald, F.R., and Jackson, C.F., 1944, Alumina from clay by the lime-sinter method: American Institute of Mining and Metallurgical Engineers Transactions, v. 159, p. 227-240.

Archibald, F.R., and Nicholson, C.M., 1949, Alumina from clay by the lime-sinter method II: American Institute of Mining and Metallurgical Engineers Transactions, v. 182, p. 14-38.

Arimori, Tsuyoshi, 1952, The manufacture of pure alumina from aluminous shale by the acid-alkali process: Chemical Society of Japan, Industrial Chemistry Section, Journal, v. 55, p. 55-59.

Arnaud, Gilbert, 1945, Les resources minières de l'Afrique Occidentale: French West Africa Direction des Mines Bulletin 8, 100 p.

Arnold, P.M., 1945, Purifying anhydrous aluminum chloride: U.S. Patent 2,387,228, assigned to Phillips Petroleum Company.

Arogyaswamy, R.N.P., 1968, Clays: India Geological Survey Bulletins, Series A, no. 29, 220 p.

Asai, Gene, Mauser, J.E., Lincoln, R.L., and Henry, J.L., 1983, Caustic extraction of alumina and soda from dawsonite-bearing oil shale: U.S. Bureau of Mines Report of Investigations 8796, 20 p.

Ashraf, Mohammad, Ahmad, Mushtaq, and Faruqi, F.A., 1976, Jurassic bauxite and kaolinite deposits of Chhoi area, Kala Chitta Range, Punjab, Pakistan: Punjab University Geological Bulletin, no. 12 , p. $41-54$.

Ashraf, Muhammad, Chohan, N.A., and Faruqi, F.A., 1972, Bauxite and clay deposits in the Kattha area, Salt Range, Punjab, West Pakistan: Economic Geology, v. 67, no. 1, p. 103-110.

Azevedo Branco, P.C. de, 1984, Principais depósitos minerais-Conceitos, metodologia e listagem, in Schobbenhaus, Carlos, Almeida Campos, Diogenes de, Derze, G.R., and Asmus, H.E., coords., Geologia do Brasil: Brasilia, Brazil Departamento Nacional da Produção Mineral, p. 359-419.

Bader, Erich, 1938, Über die Bildung und Konstitution des Dawsonits und seine synthetische Darstellung [On the formation and constitution of dawsonite and its synthetic preparation]: Neues Jahrbuch für Mineralogie, Geologie und Palaontologie, Abt. A, v. 74, no. 3 , p. $449-465$.
Bader, Erich, and Esch, U,, 1944, Versuche zur Drucksynthese des Dawsonits [Experiments on the pressure synthesis of dawsonite]: Zeitschrift für Elektrochemie, v. 50, nos. 11-12, p. 266-268.

Bakr, M.Y., and El-Abd, M.A.Z., 1969, Extraction of alumina from Egyptian kaolins and clays. Part IV, Alumina extraction by the hydrochloric acid method: Indian Journal of Technology, v. 7, no. 12 , p. 405-409.

Baksa, Cs., Bognár, L., and Lovas, Gy., 1975, Occurrence of dawsonite at Recsk (Mátra Mountains, North-Hungary): Acta Geologica (Budapest), v. 19, nos. 3-4, p. 281-286.

Barclay, J.A., 1984, Current status of R \& D on alumina from domestic nonbauxitic resources, in Jacob, Leonard, Jr., ed., Bauxite, Proceedings of the 1984 Bauxite Symposium, Los Angeles, California, February 27-March 1, 1984: New York, American Institute of Mining, Metallurgical, and Petroleum Engineers, Society of Mining Engineers, p. 165-199.

Barker, D.S., 1965, Alkalic rocks at Litchfield, Maine: Journal of Petrology, v. 6, p. 1-27.

1974, Alkaline rocks of North America, in Sørensen, H., ed., The alkaline rocks: New York, John Wiley and Sons, p. 160-171. 1977, Northern Trans-Pecos magmatic province-Introduction and comparison with the Kenya rift: Geological Society of America Bulletin, v. 88, no. 10, p. 1421-1427.

Barker, D.S., and Hodges, F.N., 1977, Mineralogy of intrusions in the Diablo Plateau, northern Trans-Pecos magmatic province, Texas and New Mexico: Geological Society of America Bulletin, v. 88, no. 10 , p. $1428-1436$.

Barker, D.S., Long, L.E., Hoops, G.K., and Hodges, F.N., 1977, Petrology and $\mathrm{Rb}-\mathrm{Sr}$ isotope geochemistry of intrusions in the Diablo Plateau, northern Trans-Pecos magmatic province, Texas and New Mexico: Geological Society of America Bulletin, v. 88, no. 10 , p. 1437-1446.

Barr, L.F.K., 1977, Alumina production from andalusite by the Pedersen process: Institution of Mining and Metallurgy (London) Transactions, sec. C, v. 86, p. C64-C70.

Barrett, P.J., Johnson, P.W., and Peters, F.A., 1973, Methods for producing alumina from clay-An evaluation of a sulfurous acidsulfuric acid process: U.S. Bureau of Mines Report of Investigations $7758,40 \mathrm{p}$.

Bascom, Florence, and Stose, G.W., 1938, Geology and mineral resources of the Honeybrook and Phoenixville quadrangles, Pa.: U.S. Geological Survey Bulletin 891, 145 p.

Batalin, Y.V., and others, 1975 [Dawsonite and perspectives of its search in the USSR]: Sovetskaya Geologiya, 1975, no. 3, p. 30-39. (In Russian.)

Bauer, D.J., Shanks, D.E., and Eisele, J.A., 1984, A strong acid-weak acid method for producing aluminum chloride hexahydrate from kaolinitic clay: U.S. Bureau of Mines Report of Investigations $8908,7 \mathrm{p}$.

Baumgardner, L.H., and Hough, R.A., 1984, Bauxite and alumina: U.S. Bureau of Mines Minerals Yearbook 1983, v. 1, p. 131-142. 1985, Bauxite and alumina: U.S. Bureau of Mines Minerals Yearbook 1984, v. 1, p. 141-152.

Beard, T.N., and Smith, J.W., 1976, In-place recovery of multiple products from Colorado's saline-mineral-bearing Piceance Basin, in Smith, John Ward, and Atwood, M.T., eds., Oil shale and tar sands: New York, American Institute of Chemical Engineers, p. $32-38$.

Beard, T.N., Tait, D.B., and Smith, J.W., 1974, Nahcolite and dawsonite resources in the Green River Formation, Piceance Creek basin, Colorado, in Murray, D.K., ed., Energy resources of the Piceance Creek basin, Colorado: Rocky Mountain Association of Geologists Field Conference, 25th, Guidebook, p. 101-109. 
Beck, W.A., 1949a, Investigation of the Andersonville bauxite district, Sumter, Macon, and Schley Counties, Ga.: U.S. Bureau of Mines Report of Investigations $4538,150 \mathrm{p}$.

1949b, Investigation of the Irwinton bauxite district, Wilkinson County, Ga.: U.S. Bureau of Mines Report of Investigations 4495, $16 \mathrm{p}$.

$1949 \mathrm{c}$, Investigation of the Springvale bauxite district, Randolph County, Ga.: U.S. Bureau of Mines Report of Investigations $4555,20 \mathrm{p}$.

Becker, G.F., 1895, Reconnaissance of the gold fields of the southern Appalachians: U.S. Geological Survey Annual Report 16, pt. 3, p. 251-319.

Beg, M.A., 1982, Evaluation of ceramic and refractory grade raw materials in Alabama-Gibbsite in saprolites of east-central Alabama: U.S. Bureau of Mines Open File Report 118-82, $80 \mathrm{p}$. 1984, Gibbsite in saprolites of the Alabama Piedmont, eastcentral Alabama: Alabama Geological Survey Circular 121, 107 p.

Beg, M.A., and others, 1978, Mineral resources of Tuscaloosa County, Alabama: Alabama Geological Survey Map 185, 78 p., 2 maps, scale about $1: 125,000$.

Beizer, James, 1974, Alcoa pilot plant changes coal waste to alumina: Iron Age, v. 213, no. 6, p. 47.

Beja, Maurice, and Vincent, Jean, 1958, Treatment of aluminum phosphates: French Patent 1,158,823, assigned to Pechiney.

Bell, K.E., 1978, The resource potential of the Whitemud Formation in Saskatchewan as a non-bauxite source of alumina: Canada Centre for Mineral and Energy Technology CANMET Report MRP/MSL 78-102(IR).

-1979, Canadian clay resources for alumina-Summary report: Canada Centre for Mineral and Energy Technology CANMET Report MRP/MSL 79-52(IR).

Bell, K.E., and Brady, J.G., 1976, A summary of Canadian clay and shale resources as sources of $\mathrm{Al}_{2} \mathrm{O}_{3}$ : Canada Centre for Mineral and Energy Technology CANMET Report MRP/MSL 76-120(OP).

Bell, P.M., 1963, Aluminum silicate system-Experimental determination of the triple point: Science, v. 139, no. 3559, p. 1055-1056.

Belsky, Milan, 1974, Method of processing aluminum-containing ores; hydrochloric and fluosilicic acids: U.S. Patent $3,816,605$, assigned to Vereinigte Aluminium-Werke A.-G.

Belsky, M., Schwind, F.A., and Winkhaus, G., 1981, A concept for alumina extraction from lignite-bearing clay with hydrochloric acid: Comité International pour l'Étude des Bauxites, de l'Alumine et de l'Aluminium Travaux, no. 16, p. 99-108.

Bengston, K.B., and others, 1978a, Alumina process feasibility study and preliminary pilot plant design. Task 1 final report, Comparison of six processes: U.S. Bureau of Mines Open File Report 18-78, $253 \mathrm{p}$.

1978b, Alumina process feasibility study and preliminary pilot plant design. Task 2 report, Comparison of two processes: U.S. Bureau of Mines Open File Report 49-78, $159 \mathrm{p}$.

-1979 , Alumina process feasibility study and preliminary pilot plant design. Task 3 report, Preliminary design of 25 ton per day pilot plant. Volume 1, Process technology and costs: U.S. Bureau of Mines Open File Report 122(1)-80, 232 p.

-1981, Some technical and economic comparisons of six processes for the production of alumina from non-bauxitic ores: Comité International pour l'Étude des Bauxites, de l'Alumine et de l'Aluminium Travaux, no. 16, p. 109-132.

Berg, R.B., 1968, Petrology of anorthosites of the Bitterroot Range, Montana, in Isachsen, Y.W., ed., Origin of anorthosite and related rocks: New York State Museum and Science Service Memoir 18, p. 387-398.

Bergquist, H.R., and Overstreet, E.F., 1965, Bauxite deposits of the Margerum district, Alabama: U.S. Geological Survey Bulletin 1199-D, $23 \mathrm{p}$.
Besson, H., Caillère, S., and Hénin, S., 1973, Remarques sur la transformation de quelques minéraux en milieu alcalin, in Serratosa, J.M., ed., Proceedings of the International Clay Conference [4th], 1972, Madrid, Spain: Madrid, Consejo Superior de Investigaciones Científicas, Division de Ciencias, p. 361-365. (English abstract.)

Beutner, H.P., and Huska, P.A., 1971, Stripping ions from an ionexchange liquid: U.S. Patent 3,586,476, assigned to Arthur D. Little, Inc., $5 \mathrm{p}$.

Bielfeldt, Klaus, Lotze, Jürgen, and Winkhaus, Günter, 1978, Ton-ein Aluminiumrohstoff? [Clay-A raw material for aluminum?]: Erzmetall, v. 31, no. 3, p. 105-110. (English summary.)

Black, R.Y., 1982, Zabirah bauxite project, phase 1 and phase 2 evaluation: Saudi Arabia Ministry of Petroleum and Mineral Resources Open-File Report RF-Of-02-6, $80 \mathrm{p}$.

Black, R.Y., Lozej, G.-P., and Maddah, S.S., 1984, Geology and mineralogy of the Zabirah bauxite, northern Saudi Arabia, in Jacob, Leonard, Jr., ed., Bauxite, Proceedings of the 1984 Bauxite Symposium, Los Angeles, California, February 27-March 1, 1984: New York, American Institute of Mining, Metallurgical, and Petroleum Engineers, Society of Mining Engineers, p. 619-638.

Blanc, G.A., 1931, Leucite as a source of alumina, potash and silica: Institution of Chemical Engineers (London) Transactions, v. 9, p. 49-62.

Blane, Philippe, Pomerol, Charles, and Maury, Roger, 1971, Présence de dawsonite dans les analcimolites des Richât (Adrar de Mauritanie): Académie des Sciences (Paris) Comptes Rendus, ser. D, v. 272 , no. 8, p. 1041-1043.

Bliss, N.W., 1976, Non-bauxite sources of alumina-A survey of Canadian potential: Canadian Mining and Metallurgical Bulletin, v. 69 , no. 774, p. $75-85$.

Bogatikov, O.A., ed., 1974, Anortozity SSR [Anorthosites of the USSR]: Moscow, Nauka, 122 p. (Translated into English by Canada Department of the Secretary of State Translation Bureau, 159 p.)

Bolger, R.C., and Weitz, J.H., 1952, Mineralogy and origin of the Mercer fireclay of north-central Pennsylvania, in Problems of clay and laterite genesis-Symposium at the annual meeting of American Institute of Mining and Metallurgical Engineers, St. Louis, Missouri, February 19-22, 1951: p. 81-93.

Bombara, Giuseppe, and Tanzi, Rocco, 1984, Prospects for carbochlorination in aluminum recovery from Italian leucitites: Journal of Metals, v. 36 , no. 1 , p. $74-78$.

Bondam, Jan, 1976, Greenland: Mining Journal, Mining Annual Review, 1975, p. 464.

Bowes, D.R., Skinner, W.R., and Skinner, D.L., 1973, Petrochemistry of the Stillwater igneous complex, Montana: Geological Society of South Africa Transactions, v. 76, pt. 2, p. 153-163.

Brabers, A.J.M., 1974, Sources of aluminium in the Republic of South Africa: South Africa Geological Survey Bulletin 59, $89 \mathrm{p}$.

Bracewell, Smith, 1962, Bauxite, alumina and aluminium: London, Great Britain Overseas Geological Survey, Mineral Resources Division, $235 \mathrm{p}$.

Bradley, W.H., 1931, Origin and microfossils of the oil shale of the Green River Formation of Colorado and Utah: U.S. Geological Survey Professional Paper 168, 58 p.

Brazil Divisão de Fomento da Produção Mineral, 1943, Brasil 1942, recursos minerais: Brazil Divisão de Fomento da Produção Mineral Boletim 56, 74 p.

Bremner, P.R., Eisele, J.A., and Bauer, D.J., 1982, Aluminum extraction from anorthosite by leaching with hydrochloric acid and fluoride: U.S. Bureau of Mines Report of Investigations 8694, $7 \mathrm{p}$.

Bremner, P.R., Nicks, L.J., and Bauer, D.J., 1984, A basic chloride method for extracting aluminum from clay: U.S. Bureau of Mines Report of Investigations 8866, 8 p. 
Brime, C., Sancho, J.P., and Verdeja, F., 1978, Possible utilization of some Spanish Terciary clays as alumina ore: 4th International Congress for the Study of Bauxites, Alumina, and Aluminum, Athens, October 9-12, 1978, Proceedings, v. 3, p. 18-30.

Bristow, C.M., 1969, Kaolin deposits of the United Kingdom of Great Britain and Northern Ireland: International Geological Congress Report of the Twenty-Third Session, Czechoslovakia, 1968, Proceedings of Symposium I, Kaolin Deposits of the World, AEurope, p. 275-288.

Brobst, D.A., 1962, Geology of the Spruce Pine district, Avery, Mitchell, and Yancey Counties, North Carolina: U.S. Geological Survey Bulletin 1122-A, 26 p.

Brobst, D.A., and Tucker, J.D., 1973, X-ray mineralogy of the Parachute Creek Member, Green River Formation, in the northern Piceance Creek basin, Colorado: U.S. Geological Survey Professional Paper 803, $53 \mathrm{p}$.

Brown, R.A., and others, 1947, Recovery of alumina from Wyoming anorthosite by the lime-soda sinter process: U.S. Bureau of Mines Report of Investigations 4132, $127 \mathrm{p}$.

Brown, R.R., Daut, G.E., Mrazek, R.V., and Gokcen, N.A., 1979, Solubility and activity of aluminum chloride in aqueous hydrochloric acid solutions: U.S. Bureau of Mines Report of Investigations $8379,17 \mathrm{p}$.

Brown, William H., 1966, Production of alumina: U.S. Patent 3,240,561, assigned to Reynolds Metals Company, $6 \mathrm{p}$.

Brown, William H., and Hrishikesan, K.G., 1966, Production of alumina: U.S. Patent 3,240,562, assigned to Reynolds Metals Company, $7 \mathrm{p}$.

Brownell, W.E., Broughton, J.G., and Peterson, R.B., 1951, The clays and shales of New York State: Albany, State of New York Department of Commerce, $349 \mathrm{p}$.

Browning, J.S., Clemmons, B.H., and McVay, T.L., 1956, Recovery of kyanite and sillimanite from Florida beach sands: U.S. Bureau of Mines Report of Investigations 5274, $12 \mathrm{p}$.

Brückner, W.D., 1957, Laterite and bauxite profiles of West Africa as an index of rhythmical climatic variations in the tropical belt: Eclogae Geologicae Helvetiae, v. 50, no. 2, p. 239-256.

Bruen, C.P., and Kelly, D.H., 1975, Alumina monohydrate from basic aluminum nitrates: U.S. Patent $3,864,462$, assigned to Reynolds Metals Company, $7 \mathrm{p}$.

Bryant, J.P., and Dixon, J.B., 1964, Clay mineralogy and weathering of a red-yellow podzolic soil from quartz mica schist in the Alabama Piedmont, in Bradley, W.F., ed., Clays and clay minerals-Proceedings of the Twelfth National Conference on Clays and Clay Minerals ***, Atlanta, Georgia, 1963: New York, Macmillan Co., p. $509-521$.

Büche, Karl, and Ginsberg, Hans, 1941, Extraction of alumina from clay with acid such as $\mathrm{HCl}$ : U.S. Patent $2,267,490$, assigned to Th. Goldschmidt A.-G.

Buddington, A.F., 1968, Adirondack anorthositic series, in Isachsen, Y.W., ed., Origin of anorthosite and related rocks: New York State Museum and Science Service Memoir 18, p. 215-232.

-1972, Differentiation trends and parental magmas for anorthositic and quartz mangerite series, Adirondacks, New York, in Shagam, R., and others, eds., Studies in earth and space sciences: Geological Society of America Memoir 132, p. 477-488.

Buie, B.F., 1978, The Huber Formation of eastern central Georgia, in Short contributions to the geology of Georgia: Georgia Geologie Survey Bulletin 93, p. 1-7.

Buie, B.F., Hetrick, J.H., Patterson, S.H., and Neeley, C.L., 1979, Geology and industrial mineral resources of the Macon-Gordon kaolin district, Georgia: U.S. Geological Survey Open-File Report 79-526, 41 p., 2 pls., scale 1:62,500.

Buie, B.F., and Schrader, E.L., 1982, South Carolina kaolin, in Nystrom, P.G., Jr., and Willoughby, R.H., eds., Geological inves- tigations related to the stratigraphy in the kaolin mining district, Aiken County, South Carolina-Carolina Geological Society Field Trip Guidebook, October 9-10, 1982: Columbia, S.C., South Carolina Geological Survey, p. 1-20.

Burgess, C.H., 1941, Igneous rocks of the Highwood Mountains, Montana. Part IV, The stocks: Geological Society of America Bulletin, v. 52, no. 11, p. 1809-1828.

Burnet, George, 1977, Alumina from fly ash, in Ruth, B.F., ed., Chemical Engineering Research Symposium, Ames, Iowa: U.S. National Technical Information Service [Report] IS-M-143, Paper $3,14 \mathrm{p}$.

Burnet, George, Murtha, M.J., and Dunker, J.W., 1983, Recovery of metals from coal ash, an annotated bibliography: Iowa State University, Ames Laboratory, Fossil Energy Report IS4833 UC$90,115 \mathrm{p}$.

-1984, Recovery of metals from coal ash, an annotated bibliography (revised): Iowa State University, Ames Laboratory, Fossil Energy Report IS4833 UC-90 (revised), $115 \mathrm{p}$.

Burnet, George, Murtha, M.J., and Wijatno, H., 1977, Recovery of alumina from fly ash by high-temperature chlorination, in Rose, J.G., ed., Proceedings, Third Kentucky Coal Refuse Disposal and Utilization Seminar, May 11-12, 1977, Lexington, Ky.: Lexington, Ky., University of Kentucky, p. 83-88.

Buroš, Juraj, and Wagner, Hermann, comps., 1978, UdSSR-Aluminium: (Federal Republic of Germany) Bundesanstalt für Geowissenschaften und Rohstoffe, Rohstoffwirtschaftliche Länderberichte 17, 86 p. (English, French, and Russian summaries.)

Burst, J.F., 1974, Genetic relationship of the Andersonville, Georgia, and Eufaula, Alabama, bauxitic kaolin areas: American Institute of Mining, Metallurgical, and Petroleum Engineers Transactions, v. 256 , p. $137-143$.

Bushinsky, G.I., and Bogolyubova, L.I., 1960, Konkretsii fosfatizirovannogo boksita iz nizhneyurskogo ugolnogo plasta v okrestnostyakh g. Karpinska na severnom Urale [Phosphatized bauxite concretions in the lower Jurassic coal seam in the vicinity of Karpinsk in the northern Urals]: Akademiya Nauk SSSR, Izvestiya, Seriya Geologicheskaya, 1960, no. 1, p. 49-55. (English translation in Academy of Sciences of the USSR Bulletin, Geologic Series, 1960, no. 1 , p. 41-46.)

Cada, R.B., Ishijima, Itaru, and Saeki, Yozo, 1972, Formation of dawsonite by decomposition of sodium aluminate solution with carbon dioxide: Philippines Bureau of Mines Report of Investigation $72,20 \mathrm{p}$.

Cady, J.G., 1951, Rock weathering and soil formation in the North Carolina Piedmont region: Soil Science Society of America Proceedings 1950 , v. 15 , p. 337-342.

Calver, J.L., 1949, Florida kaolins and elays: Florida Geological Survey Information Circular 2, $59 \mathrm{p}$.

1957, Mining and mineral resources: Florida Geological Survey Bulletin 39, $132 \mathrm{p}$.

Calver, J.L., Hamlin, H.P., and Wood, R.S., 1961, Analyses of clay, shale and related materials-Northern counties: Virginia Division of Mineral Resources, Mineral Resources Report 2, $194 \mathrm{p}$.

Calver, J.L., Smith, C.E., and LeVan, D.C., 1964, Analyses of clay, shale and related materials - West-central counties: Virginia Division of Mineral Resources, Mineral Resources Report 5, $230 \mathrm{p}$.

Calvert, C.S., Buol, S.W., and Weed, S.B., 1980, Mineralogical characteristics and transformations of a vertical rock-saprolite-soil sequence in the North Carolina Piedmont. I, Profile morphology, chemical composition, and mineralogy. II, Feldspar alteration products-Their transformations through the profile: Soil Science Society of America Journal, v. 44, no. 5, p. 1096-1112. 
Capdecomme, Laurent, 1953, Étude minéralogique des gîtes de phosphates alumineux de la région de Thiès (Sénégal): International Geological Congress, 19th, Algiers, 1952, Comptes Rendus, sec. 11 , pt. 11, p. 103-117.

Capdecomme, Laurent, and Pulou, René, 1954, Sur la radioactivité des phosphates de la région de Thiès (Sénégal): Académie des Sciences (Paris) Comptes Rendus, v. 239, no. 3, p. 288-290.

Carter, Bruce, and Silver, L.T., 1972, Structure and petrology of the San Gabriel anorthosite-syenite body, California: International Geological Congress, 24th, Montreal, 1972, Proceedings, sec. 2, p. 303-311.

Cate, R.B., and McCracken, R.J., 1972, Gibbsite in western North Carolina: Southeastern Geology, v. 14, no. 2, p. 107-112.

Cathcart, J.B., 1963, Economic geology of the Plant City quadrangle, Florida: U.S. Geological Survey Bulletin 1142-D, 56 p.

Cathcart, J.B., Blade, L.V., Davidson, D.F., and Ketner, K.B., 1953, The geology of the Florida land-pebble phosphate deposits: International Geological Congress, 19th, Algiers, 1952, Comptes Rendus, sec. 11 , pt. 11, p. 77-91.

Cathcart, J.B., and Houser, F.N., 1950, Development and distribution of leached rock in the land pebble phosphate district, Florida [abs.]: Geological Society of America Bulletin, v. 61, no. 12, pt. 2, p. $1449-1450$.

Cavin, D.C., 1974, A study of iron and aluminum recovery from power plant fly ash: Ames, Iowa State University, Ph.D. thesis, 121 p. (Released as U.S. National Technical Information Service [Report] IS-T-611.)

Chemical Engineering, 1984, Recovery of alumina and other minerals from coal flyash could be profitable: Chemical Engineering, v. 91, no. 17, p. 20.

Chemical Week, 1957, Mineral bonanza brewing in Carolinas?: Chemical Week, August 31st, p. 39-40.

Cho, M.S., and Son, Y.U., 1978 [Studies on the extraction of alumina from alunite (Part 1)]: Chawŏn Kaebal Yŏn'guso Chosa Yŏn'gu Pogo [South Korea Research Institute of Geoscience and Mineral Resources Report], v. 4, p. 197-216. (In Korean; English abstract.)

Chou, K.S., 1976, A study of the extractability of alumina from fly ash by the lime-sinter process: U.S. National Technical Information Service [Report] IS-T-716, $127 \mathrm{p}$.

Chou, K.S., Klemm, W.A., Murtha, M.J., and Burnet, George, 1976, The lime sinter process for the production of alumina from fly ash, in Spencer, J.D., and Whieldon, C.E., eds., Fourth International Ash Utilization Symposium Proceedings: U.S. Department of Energy, DOE/MERC/Sp-76/4, p. 433-449.

Christie, P., and Derry, R., 1976, Aluminium from indigenous UK resources-A review of possibilities: Stevenage Engineering, Warren Spring Laboratory, Report LR 219, 114 p.

Chronic, John, and Matsushita, Hiromi, 1974, Selected bibliography of the geology of northwestern Colorado, with special emphasis on oil shale geology and technology, in Murray, D.K., ed., Energy resources of the Piceance Creek basin, Colorado: Rocky Mountain Association of Geologists Field Conference, 25th, Guidebook, p. 261-274.

Clark, L.D., 1965, Bauxite deposits of the Springvale district, Georgia: U.S. Geological Survey Bulletin 1199-F, 24 p.

Clarke, F.W., 1924, The data of geochemistry (5th ed.): U.S. Geological Survey Bulletin 770, 841 p.

Clarke, O.M., Jr., 1963, Residual clays of the Piedmont province in Alabama: Alabama Geological Survey Circular 20-A, 60 p.

1964, Clay deposits of the Tuscaloosa Group in Alabama, in Bradley, W.F., ed., Clays and clay minerals-Proceedings of the Twelfth National Conference on Clays and Clay Minerals ***, Atlanta, Georgia, 1963: New York, Macmillan Co., p. 495-507.
1971, Gibbsite in Coastal Plain soils, southeastern United States: Southeastern Geology, v. 13, no. 2, p. 77-90.

1972, Bauxite and kaolin in the Eufaula bauxite district, Alabama: Alabama Geological Survey Bulletin 100, 90 p.

Cleveland, G.B., 1957a, Aluminum, in Wright, L.A., ed., Mineral commodities of California: California Division of Mines Bulletin 176 , p. 29-33.

1957b, Clay, in Wright, L.A., ed., Mineral commodities of California: California Division of Mines Bulletin 176, p. 131-152.

Closmann, P.J., and Suman, G.O., Jr., 1974, Recovery of oil from oil shale: U.S. Patent 3,804,172, assigned to Shell Oil Company, 5 p.

Cloud, P.E., Jr., 1966, Bauxite deposits of the Anniston, Fort Payne, and Ashville areas, northeast Alabama: U.S. Geological Survey Bulletin 1199-0, 35 p.

1967, Geology and bauxite deposits of the Rock Run and Goshen Valley areas, northeast Alabama: U.S. Geological Survey Bulletin $1199-\mathrm{N}, 74 \mathrm{p}$.

Coalgate, J.L., undated, Literature survey-Coal associated wastes 1900-1972: West Virginia University Coal Research Bureau Report 115, $124 \mathrm{p}$.

Coats, R.R., Consul, Jerry, and Neil, S.T., 1979, Masive zunyite rock from western Elko County, Nevada: U.S. Geological Survey Open-File Report 79-764, $10 \mathrm{p}$.

Cocco, A., Colussi, I., and Meriani, S., 1978, Potential exploitation of leucite-bearing rocks for alumina extraction-A laboratory approach: 4th International Congress for the Study of Bauxites, Alumina and Aluminum, Athens, October 9-12, 1978, Proceedings, v. 3, p. $31-43$.

1981, An overall evaluation of a new process for alumina production from leucite-bearing rocks: Comité International pour l'Étude des Bauxites, de l'Alumine et de l'Aluminium Travaux, no. 16, p. 31-37.

Cochran, C.N., 1980, Method of carbothermically producing aluminumsilicon alloy: Aluminium (Düsseldorf), v. 56, no. 3, p. 233.

Cochran, C.N., Das, S.K., and Milito, R.A., 1977, Method of carbothermically producing aluminum-silicon alloys: U.S. Patent $4,053,303$, assigned to Aluminum Company of America.

Coetzee, C.B., 1969, Kaolin deposits of the Republic of South Africa: International Geological Congress Report of the Twenty-Third Session, Czechoslovakia, 1968, Proceedings of Symposium I, Kaolin Deposits of the World, B-Oversea Countries, p. 61-65.

Cofer, H.E., Jr., and Manker, J.P., 1983, Geology and resources of the Andersonville, Georgia, kaolin and bauxite district: U.S. Geological Survey Open-File Report 83-580, 98 p., 3 oversize sheets, scale 1:24,000.

Cofer, H.E., Jr., Wright, N.A., and Carey, M.A., 1976, Preliminary report on the kaolin and bauxite deposits of the Andersonville district, Georgia: U.S. Geological Survey Open-File Report $76-682,23 \mathrm{p}$.

Cohen, Joseph, and Adjemian, Alain, 1978a, Pure alumina: German Patent 2,807,850, assigned to Aluminium Pechiney, $33 \mathrm{p}$.

-1978b, Very pure alumina: German Patent 2,807,862, assigned to Aluminium Pechiney, 29 p. (This process also received U.S. Patent 4,124,680.)

Cohen, Joseph, and Mercier, Henri, 1976, Recovery of alumina from non-bauxite aluminum-bearing raw materials, in Leavitt, S.R., ed., Light metals 1976-Proceedings of sessions, 105th AIME annual meeting, Las Vegas, Nevada: New York, American Institute of Mining, Metallurgical, and Petroleum Engineers, v. 2, p. 3-18.

Cole, R.D., Daub, G.J., and Weichman, B.E., 1982, Geology of the Horse Draw nahcolite and oil-shale mine, Piceance Creek basin, Colorado, in Gary, J.H., ed., Fifteenth Oil Shale Symposium proceedings: Golden, Colo., Colorado School of Mines Press, p. $15-28$. 
Collings, R.K., and Brown, G.A., 1976, Alumina resources in CanadaNepheline syenite and kyanite: Canada Centre for Mineral and Energy Technology CANMET Report MRP/MSL 76-142(OP).

Colorado School of Mines, 1964, First symposium on oil shale: Colorado School of Mines Quarterly, v. 59, no. 3, 163 p.

-1965 , Second symposium on oil shale: Colorado School of Mines Quarterly, v. 60, no. 3, 200 p.

1966, Third symposium on oil shale: Colorado School of Mines Quarterly, v. 61, no. 3, 170 p.

1967, Fourth symposium on oil shale: Colorado School of Mines Quarterly, v. 62, no. 3, 173 p.

-1968, Fifth symposium on oil shale: Colorado School of Mines Quarterly, v. 63, no. 4, $167 \mathrm{p}$.

Conant, L.C., 1965, Bauxite and kaolin deposits of Mississippi, exclusive of the Tippah-Benton district: U.S. Geological Survey Bulletin $1199-\mathrm{B}, 70 \mathrm{p}$.

Condry, L.Z., 1976, Recovery of aluminum from coal refuse-An annotated bibliography: West Virginia University Coal Research Bureau Report 130, 8 p.

Conley, J.E., and others, 1947, Production of metallurgical alumina from Pennsylvania nodular diaspore clays: U.S. Bureau of Mines Bulletin 465, $193 \mathrm{p}$.

Copson, R.L., Walthall, J.H., and Hignett, T.P., 1944a, Extraction of alumina from clays by the lime-sinter modification of the Pedersen process: [U.S.] National Academy of Sciences War Metallurgy Committee Research Report W-103, 114 p.

1944b, Extraction of alumina from clays by the lime-sinter modification of the Pedersen process: American Institute of Mining and Metallurgical Engineers Transactions, v. 159, p. 241-254.

Councill, R.J., and Llewellyn, C.M., Jr., 1959, Alumina content of some residual soils in the Piedmont of South Carolina [abs.]: North Carolina Academy of Science Proceedings, in Elisha Mitchell Scientific Society Journal, v. 75, no. 2, p. 68.

Coveney, R.M., and Kelley, W.C., 1971, Dawsonite as a daughter mineral in hydrothermal fluid inclusions: Contributions to Mineralogy and Petrology, v. 32, no. 4, p. 334-342.

Covino, B.S., Jr., Rosen, Murray, and Riley, W.D., 1981, Corrosion resistance of materials in the aqueous hydrochloric acid environments associated with the recovery of aluminum from kaolinitic clays: U.S. Bureau of Mines Report of Investigations 8565, 28 p.

Cox, K.C., 1979, Experiences in equipping a 96-inch-diameter shaft, and mining bulk samples of oil shale, dawsonite and nahcolite, in Gary, J.H., ed., Twelfth Oil Shale Symposium proceedings: Golden, Colo., Colorado School of Mines Press, p. 179-183.

Crawford, W.A., Robelen, P.G., and Kalmbach, J.H., 1971, The Honey Brook anorthosite: American Journal of Science, v. 471, no. 4, p. 333-349.

Crider, A.F., 1913, The fire clays and fire clay industries of the Olive Hill and Ashland districts of northeastern Kentucky: Kentucky Geological Survey, ser. 4, v, 1, pt. 2, p. 589-711.

Crocket, R.N., comp., 1975, Slate: Great Britain Institute of Geological Sciences, Mineral Resources Consultative Committee, Mineral Dossier 12, $26 \mathrm{p}$.

Csejtey, Béla, Jr., and Patton, W.W., Jr., 1974, Petrology of the nepheline syenite of St. Lawrence Island, Alaska: U.S. Geological Survey Journal of Research, v. 2, no. 1, p. 41-47.

Cservenyak, F.J., 1947, Recovery of alumina from kaolin by the lime-soda sinter process: U.S. Bureau of Mines Report of Investigations $4069,59 \mathrm{p}$.

Damiani, L., and Trautmann, F., 1969, Les dépôts de kaolins français: International Geological Congress Report of the Twenty-Third Session, Czechoslovakia, 1968, Proceedings of Symposium I, Kaolin Deposits of the World, A-Europe, p. 141-178.
Darton, N.H., and Paige, Sidney, 1925, Description of the central Black Hills [South Dakota]: U.S. Geological Survey Geologic Atlas, Folio 219, 34 p., 7 maps.

Davidson, D.M., Jr., 1972, Eastern part of Duluth Complex, in Sims, P.K., and Morey, G.B., eds., Geology of Minnesota, a centennial volume: St. Paul, Minn., Minnesota Geological Survey, p. 354-360.

Davies, D.N., Urie, J.G., Jones, D.H., and Winter, P.E., 1964, The alumina, pyrophyllite, and silica deposits in the Insuzi Series, Mahlangatsha and Mkopeleli areas, Shiselweni and Manzini districts: Swaziland Geological Survey and Mines Department Bulletin 4, p. 5-22.

Davis, C.E. [1975], Alternatives to bauxite, in Proceedings of Bauxite Symposium III [Kingston, Jamaica], May 1975: Geological Society of Jamaica Journal, Special Issue, p. 38-43.

Dean, R.S., 1975, Mineralogy of ceramic clays and shales of the Atlantic provinces: Canada Centre for Mineral and Energy Technology Scientific Bulletin CM 75-8, 97 p.

Dean, W.E., Pitman, J.K., and Harrach, G.H., 1981, Geochemical and mineralogical analyses of U.S. Geological Survey oil-shale core CR-2, Piceance Creek basin, Colorado: U.S. Geological Survey Open-File Report 81-596, $93 \mathrm{p}$.

DeCarlo, V.A., and others, 1978, Evaluation of potential processes for the recovery of resource materials from coal residues-Fly ash: U.S. Department of Energy, Oak Ridge National Laboratory Report ORNL/TM-6126.

Denson, N.M., and Waagé, K.M., 1966, Some bauxite and clay deposits in northeastern Alabama: U.S. Geological Survey Bulletin 1199-P, $27 \mathrm{p}$.

Derry, D.R., and Phipps, C.V.G., 1957, Nepheline syenite deposit, Blue Mountain, Ontario, in Canadian Institute of Mining and Metallurgy, Industrial Minerals Division, The geology of Canadian industrial mineral deposits: Toronto, Commonwealth Mining and Metallurgical Congress, 6th, 1957, p. 190-195.

Desborough, G.A., and Pitman, J.K., 1974, Significance of applied mineralogy to oil shale in the upper part of the Parachute Creek Member of the Green River Formation, Piceance Creek basin, Colorado, in Murray, D.K., ed., Energy resources of the Piceance Creek basin, Colorado: Rocky Mountain Association of Geologists Field Conference, 25th, Guidebook, p. 81-89.

Desborough, G.A., Pitman, J.K., and Huffman, Claude, Jr., 1974, Concentration and mineralogical residence of elements in rich oil shales of the Green River Formation, Piceance Creek basin, Colorado, and the Uinta basin, Utah-A preliminary report: U.S. Geological Survey Open-File Report 74-77, $14 \mathrm{p}$.

De Vore, G.W., 1975, The role of partial melting of metasediments in the formation of anorthosite-norite-syenite complex, Laramie Range, Wyoming: Journal of Geology, v. 83, no. 6, p. 749-762.

DeVoto, R.H., Stevens, D.N., and Bloom, D.N., 1970, Dawsonite and gibbsite in the Green River Formation: Mines Magazine, v. 60, no. 5 , p. 17-21.

Dewing, E.W., Huni, J.P.R., Sood, R.R., and Southam, F.W., 1978, Process for the production of aluminum: U.S. Patent 4,099,959, assigned to Alcan Aluminium International Limited.

Dmitriyev, F.L., and others, 1975 [Dawsonite in the lower Carboniferous formation of the Pripet basin in Byelorussia], in Bushinskiy, G.I., ed., Problemy genezisa boksitov [Problems of bauxite genesis]: Moscow, Nauka, p. 291-302.

Doerr, R.M., 1982, Laboratory studies on the treatment of ferric chloride stripping liquor from a clay-hydrochloric acid leaching process: U.S. Bureau of Mines Report of Investigations 8725, $7 \mathrm{p}$.

Donnell, J.R., 1961, Tertiary geology and oil-shale resources of the Piceance Creek basin between the Colorado and White Rivers, northwestern Colorado: U.S. Geological Survey Bulletin 1082-L, p. 835-891. 
Donnell, J.R., and Smith, M.C., 1980, Acid-extractable alumina and water-soluble sodium analyses and histograms of Eocene Green River Formation from U.S. Geological Survey coreholes CR-1 and CR-2, Piceance Creek basin, Rio Blanco County, Colorado: U.S. Geological Survey Open-File Report 80-663, 50 p.

Dugger, G.L., Adams, J.B., and Bart, Roger, 1955, Digestion and filtration of leached zone in pilot plant: U.S. Atomic Energy Commission [Report] RMO-2044, $35 \mathrm{p}$.

Duncan, D.C., and Swanson, V.E., 1965, Organic-rich shale of the United States and world land areas: U.S. Geological Survey Circular 523, $30 \mathrm{p}$.

Dunlap, J.C., Bergquist, H.R., Craig, L.C., and Overstreet, E.F., 1965, Bauxite deposits of Tennessee: U.S. Geological Survey Bulletin 1199-L, 37 p.

Dyni, J.R., 1972, Extracting aluminum compounds from dawsonite and dawsonitic oil shale: U.S. Patent $3,642,433$, assigned to the Secretary of the Interior, $3 \mathrm{p}$.

1974 , Stratigraphy and nahcolite resources of the Saline facies of the Green River Formation in northwest Colorado, in Murray, D.K., ed., Energy resources of the Piceance Creek basin, Colorado: Rocky Mountain Association of Geologists Field Conference, 25th, Guidebook, p. 111-122.

-1980, Colorado nahcolite deposits-Geology and outlook for development: American Institute of Mining, Metallurgical, and Petroleum Engineers, Society of Mining Engineers, Transactions, v. 270 , p. $1853-1859$.

Dyni, J.R., and Hite, R.J., 1968, Potential resources of dawsonite and nahcolite in the oil-shale deposits of the Green River Formation, northwest Colorado, USA: United Nations Symposium on the Development and Utilization of Oil Shale Resources, 1st, Tallinn, USSR, 1968, p. 1-26.

Edlund, V.E., 1982, Lime-sinter processing of anorthosite for the recovery of alumina: U.S. Bureau of Mines Report of Investigations $8714,21 \mathrm{p}$.

Edwards, J.D., 1949, The combination process for alumina: American Institute of Mining and Metallurgical Engineers Transactions, v. 182, p. 9-13.

Edwards, J.D., Frary, F.C., and Jeffries, Zay, 1930, Aluminum and its production, [v. 1] of The aluminum industry: New York, McGrawHill, $358 \mathrm{p}$.

Egan, B.Z., Seeley, F.G., and Kelmers, A.D., 1980, Chemistry of the calsinter process for recovery of aluminum from fly ash: American Institute of Mining, Metallurgical, and Petroleum Engineers, Society of Mining Engineers, Reprint 80-47, $11 \mathrm{p}$.

Eisele, J.A., 1980, Producing alumina from clay by the hydrochloric acid process, a bench-scale study: U.S. Bureau of Mines Report of Investigations $8476,21 \mathrm{p}$.

Eisele, J.A., and Bauer, D.J., 1979, Evaluation of technology for the recovery of metallurgical-grade alumina from coal ash: U.S. Bureau of Mines Information Circular 8791, $9 \mathrm{p}$.

1983, Recovery of alumina from anorthosite by HCl-F-gas sparging crystallization process: U.S. Bureau of Mines Report of Investigations $8806,11 \mathrm{p}$.

Eisele, J.A., Bauer, D.J., and Shanks, D.E., 1983, Bench-scale studies to recover alumina from clay by a hydrochloric acid process: Industrial and Engineering Chemistry, Product Research and Development, v. 22, no. 1, p. 105-110.

Eisele, J.A., Schultze, L.E., Berinati, D.J., and Bauer, D.J., 1976, Amine extraction of iron from aluminum chloride leach liquors: U.S. Bureau of Mines Report of Investigations 8188, $10 \mathrm{p}$.

Eisele, J.A., Smith, F.R., and Bauer, D.J., 1982, Iron extraction from simulated aluminum nitrate leach liquor: U.S. Bureau of Mines Report of Investigations 8634, $9 \mathrm{p}$.

El Badry, Oussama, Hassaan, M., and El Sheimi, A., 1981, Contribution to geochemistry of some claystones and kaolinites of Kalabsha,
Egypt: Comité International pour l'Étude des Bauxites, de l'Alumine et de l'Aluminium Travaux, no. 16, p. 325-332.

El Ramly, M.F., Budanov, V.I., Hussein, A.A.A., and Dereniuk, N.E., 1970, Ring complexes in the south-eastern desert of Egypt, in Moharram, Osman, and others, eds., Studies on some mineral deposits of Egypt: [Cairo] United Arab Republic Geological Survey, p. 181-194.

El Ramly, M.F., Dereniuk, N.E., Armanicus, L.K., and Shaaban, A.S., 1970, Assessment and technological testing of the nepheline syenites of Gabal Abu Khruq [Jabal Abū Khurūq], in Moharram, Osman, and others, eds., Studies on some mineral deposits of Egypt: [Cairo] United Arab Republic Geological Survey, p. 155-180.

El Ramly, M.F., Kotb, Said, and Osman, Fathi, 1971, Geology of Wadi Kalabsha kaolin deposit, in Said, Kushdi, and Mansour, A.O., eds., The discovery of a new kaolin deposit in Wadi Kalabsha, Nubia, Egypt: Egypt Geological Survey and Mining Authority Paper 54, p. 1-38.

Energy Research Digest, 1977, ERDA funds aluminum making process: Energy Research Digest, v. 3, no. 19, p. 1, 3.

Engineering and Mining Journal, 1954, Argentina: Engineering and Mining Journal, v. 155 , no. 7, p. 148, 150.

1963, Georgia: Engineering and Mining Journal, v. 164, no. 8, p. 155 .

1970, Gibbsite Corp. hopes new patent will allow gibbsite mining for aluminum in South: Engineering and Mining Journal, v. 171, no. 2, p. 110.

1973, Aluminum plant using new Toth process to be built in Europe: Engineering and Mining Journal, v. 174, no. 8, p. 26.

Erickson, R.L., and Blade, L.V., 1963, Geochemistry and petrology of the alkalic igneous complex at Magnet Cove, Arkansas: U.S. Geological Survey Professional Paper 425, 95 p.

Espenshade, G.H., 1961, Resources, chapter 3, of Klinefelter, T.A., and Cooper, J.D., Kyanite, a materials survey: U.S. Bureau of Mines Information Circular 8040, p. 8-19.

1962, Pyrophyllite and kyanite and related minerals in the United States, exclusive of Alaska and Hawaii: U.S. Geological Survey Mineral Investigations Resource Map MR-18, scale $1: 3,168,000$.

1973, Kyanite and related minerals, in Brobst, D.A., and Pratt, W.P., eds., United States mineral resources: U.S. Geological Survey Professional Paper 820, p. 307-312.

Espenshade, G.H., and Boudette, E.L., 1967, Geology and petrology of the Greenville quadrangle, Piscataquis and Somerset Counties, Maine: U.S. Geological Survey Bulletin 1241-F, $60 \mathrm{p}$.

Espenshade, G.H., and Potter, D.B., 1960, Kyanite, sillimanite, and andalusite deposits of the southeastern States: U.S. Geological Survey Professional Paper 336, $121 \mathrm{p}$.

Espenshade, G.H., and Spencer, C.W., 1963, Geology of phosphate deposits of northern peninsular Florida: U.S. Geological Survey Bulletin 1118, $115 \mathrm{p}$.

Estep, P.A., and Karr, Clarence, Jr., 1968, The infrared spectra of dawsonite: American Mineralogist, v. 53, nos. 1-2, p. 305-309.

Eyles, V.A., 1958, A phosphatic band underlying bauxite deposits in Jamaica: Nature, v. 182 , no. 4646, p. 1367-1368.

Eyles, V.A., and others, 1952, The composition and origin of the Antrim laterites and bauxites: Belfast, Northern Ireland Geological Survey Memoir, $90 \mathrm{p}$.

Farris, C.B., and Leland, E.H., 1978, Dawsonite and nahcolite survey. Volume 2, Dawsonite and nahcolite bibliography with abstracts: U.S. Department of Energy, Division of Industrial Energy Conservation IDO-1683-1, $110 \mathrm{p}$.

Farris, C.B., and Mains, C.J., 1978, Dawsonite and nahcolite survey. Volume 1, Reserves, technology, economics, and market assess- 
ment: U.S. Department of Energy, Division of Industrial Energy Conservation IDO-1683-1, $156 \mathrm{p}$.

Faruqi, F.A., 1966, Mineralogical and ceramic investigations on a high alumina clay from Skesar Hills: Pakistan Journal of Scientific and Industrial Research, v. 9, no. 2, p. 146-149.

Ferrante, M.J., Stuve, J.M., and Richardson, D.W., 1976, Thermodynamic data for synthetic dawsonite: U.S. Bureau of Mines Report of Investigations 8129, $13 \mathrm{p}$.

Fetterman, J.W., 1961, Alumina extraction from a Pennsylvania diaspore clay by an ammonium sulfate process: University Park, Pa., Pennsylvania State University, Ph.D. thesis, $151 \mathrm{p}$.

Fetterman, J.W., and Sun, S.-C., 1963, Alumina extraction from a Pennsylvania diaspore clay by an ammonium sulfate process, in Proceedings of the International Symposium on the Extractive Metallurgy of Aluminum: New York, American Institute of Mining, Metallurgical, and Petroleum Engineers, v. 1, p. 333-349.

Finley, F.L., 1930, The nepheline syenites and pegmatites of Mount Royal, Montreal, Quebec: Canadian Journal of Research, v. 2, no. 4, p. 231-248.

Fish, G.E., Jr., 1962, Titanium resources of Nelson and Amherst Counties, Va. Part I, Saprolite ores: U.S. Bureau of Mines Report of Investigations 6094, $44 \mathrm{p}$.

Fleischer, Arthur, 1944, The Kalunite process: American Institute of Mining and Metallurgical Engineers Transactions, v. 159, p. 267-279.

Flicoteaux, René, Nahon, Daniel, and Paquet, Hélène, 1977, Genèse des phosphates alumineux à partir des sédiments argilophosphatés du Tertiaire de Lam-Lam (Sénégal). Suite minéralogique-Permanences et changements de structures: (Université Louis Pasteur de Strasbourg Institut de Géologie) Sciences Géologiques Bulletin, v. 30, no. 3, p. 153-174. (English summary.)

Flint, E.P., and others, 1946, Extraction of alumina from clays and high-silica bauxites: U.S. National Bureau of Standards Journal of Research, v. 36 , p. $63-106$.

Flood, H.W., 1971, Removal of ferric iron from aqueous solutions of aluminum salts dissolved in strong mineral acids: U.S. Patent $3,586,477$, assigned to Arthur D. Little, Inc., 3 p.

Foose, R.M., 1944, High-alumina clays of Pennsylvania: Economic Geology, v. 39, no. 8, p. 557-577.

Ford, W.E., 1932, A textbook of mineralogy by Edward Salisbury Dana (4th ed. revised and enlarged by W.E. Ford): New York, John Wiley and Sons, Inc., 851 p.

Foster, W.R., 1960, The sillimanite group-Kyanite, andalusite, sillimanite, dumortierite, topaz, in Gillson, J.L., and others, eds., Industrial minerals and rocks-Nonmetallics other than fuels (3d ed. completely revised): New York, American Institute of Mining, Metallurgical, and Petroleum Engineers, p. 773-789.

Frueh, A.J., Jr., and Golightly, J.P., 1967, The crystal structure of dawsonite $\mathrm{NaAl}\left(\mathrm{CO}_{3}\right)(\mathrm{OH})_{2}$ : Canadian Mineralogist, v. 9, pt. 1, p. 51-57.

Fujii, Noriyuki, Okana, T., and Shimazaki, Y., 1969, Kaolin deposits of Japan: International Geological Congress Report of the TwentyThird Session, Czechoslovakia, 1968, Proceedings of Symposium I, Kaolin Deposits of the World, B-Oversea Countries, p. 29-37.

Fujii, Noriyuki, Togashi, Yukio, and Igarashi, Toshio, 1976, An outline of kaolin, pyrophyllite and sericite clay deposits in Japan: Tokyo, Japan Geological Survey, 25 p. (To accompany Japan Geological Survey 1:2,000,000 Map Series [Map] 17-1.)

Fulda, Wilhelm, Wiedbrauck, Erich, and Büche, Karl, 1938, Process for the recovery of aluminum compounds from aluminiferous minerals: U.S. Patent 2,123,650, assigned to Th. Goldschmidt A.-G.

1941, Manufacture of monobasic aluminum sulfite: U.S. Patent 2,243,060, assigned to Th. Goldschmidt A.-G.
Fulda, Wilhelm, Wiedbrauck, Erich, and Wittig, R., 1935, Method of producing pure alumina: U.S. Patent 2,021,546, assigned to Vereinigte Aluminium-Werke A.-G. and Th. Goldschmidt A.-G.

Fulda, Wilhelm, Wrigge, Wilhelm, and Logemann, Heinrich, 1941, Separation of sulfur dioxide from aluminum sulfites: U.S. Patent $2,261,113$, assigned to Th. Goldschmidt A.-G.

Funaki, K., 1950, The sulfuric acid process for obtaining pure alumina from its ores: Tokyo Institute of Technology Bulletin, ser. B, no. $1,165 \mathrm{p}$.

Gabinet, M.P., and Lozynyak, P.Yu., 1975 [Dawsonite in the Carpathian flysch]: Mineralogicheskii Sbornik (Lvov), v. 29, no. 2, p. 33-35. (In Russian.)

Gabler, R.C., Jr., and Stoll, R.L., 1983, Removal of leachable metals and recovery of alumina from utility coal ash: U.S. Bureau of Mines Report of Investigations $8721,20 \mathrm{p}$.

Galaburda, S.G., 1958 [Raw deposits of light metals in eastern Siberia], in Bessolitsyn, E.P., and others, eds., Syrevye resursy legkikh metallov vostochnoi Sibiri, v. II: Akademiya Nauk SSSR, Vostochno-Sibirskii Filial, Trudy, no. 13, p. 19-31.

Galán Huertos, E., and Espinosa de los Monteros, J., 1974, El caolín en Espana-Características, identificación y ensayos cerámicos: Madrid, Sociedad Española de Cerámica y Vidrio, 229 p.

Galán Huertos, E., and Martín Vivaldi, J.L., 1973, Genetic classification of the Spanish kaolin deposits and their typology, in Serratosa, J.M., ed., Proceedings of the International Clay Conference [4th], 1972, Madrid, Spain: Madrid, Consejo Superior de Investigaciones Científicas, Division de Ciencias, p. 737-748.

Gary, J.H., ed., 1970, Synthetic liquid fuels from oil shale, tar sands, and coal: Colorado School of Mines Quarterly, v. 65, no. 4, 241 p. -ed., 1974, Proceedings of the seventh Oil Shale Symposium: Colorado School of Mines Quarterly, v. 69, no. 2, 231 p. ed., 1975, Proceedings of the eighth Oil Shale Symposium: Colorado School of Mines Quarterly, v. 70, no. 3, 313 p.

ed., 1976, Proceedings of the ninth Oil Shale Symposium: Colorado School of Mines Quarterly, v. 71, no. 4, 344 p.

ed., 1977, Tenth Oil Shale Symposium proceedings: Golden, Colo., Colorado School of Mines Press, $256 \mathrm{p}$.

ed., 1978, Eleventh Oil Shale Symposium proceedings: Golden, Colo., Colorado School of Mines Press, $389 \mathrm{p}$.

ed., 1979, Twelfth Oil Shale Symposium proceedings: Golden, Colo., Colorado School of Mines Press, 395 p.

ed., 1980, Thirteenth Oil Shale Symposium proceedings: Golden, Colo., Colorado School of Mines Press, 391 p.

ed., 1981, Fourteenth Oil Shale Symposium proceedings: Golden, Colo., Colorado School of Mines Press, 433 p.

ed., 1982, Fifteenth Oil Shale Symposium proceedings: Golden, Colo., Colorado School of Mines Press, $597 \mathrm{p}$.

ed., 1983, Sixteenth Oil Shale Symposium proceedings: Golden, Colo., Colorado School of Mines Press, 611 p. ed., 1984, Seventeenth Oil Shale Symposium proceedings: Golden, Colo., Colorado School of Mines Press, 440 p.

ed., 1985, Eighteenth Oil Shale Symposium proceedings: Golden, Colo., Colorado School of Mines Press, 354 p.

Gaskin, A.J., 1969, Kaolin deposits of Australia: International Geological Congress Report of the Twenty-Third Session, Czechoslovakia, 1968, Proceedings of Symposium I, Kaolin Deposits of the World, B-Oversea Countries, p. 115-150.

Gaskin, A.J., Darragh, P.J., and Loughnan, F.C., 1979, Australian kaolins, in Mortland, M.M., and Farmer, V.C., eds., International Clay Conference 1978, Proceedings of the VI International Clay Conference 1978 held in Oxford [England], 10-14 July 1978: New York, Elsevier, p. 591-599.

Gauhar, S.H., 1976, Mineral resources of Pakistan (Summary report for 1974): Geonews (Pakistan Geological Survey), v. 5, no. 1, p. 3-14. 
Gejrot, Claes, 1958, [Company report by] Svenska Skifferolje AB: Orebro, Sweden, 35 p.

George, D.R., Tame, K.E., Crane, S.R., and Higbie, K.B., 1968, Recovery and production of alumina from waste solutions by solvent extraction: Journal of Metals, v. 20 , no. 9, p. 59-63.

George, J.H.B., and Stone, E.W., 1965, Removal of $\mathrm{Fe}^{3+}$ from acidic solutions of aluminum nitrate or aluminum sulfate: U.S. Patent $3,211,521$, assigned to Arthur D. Little, Inc., 6 p.

George, M., and Jackson, L., 1984, Bibliographic data base on trace elements in oil shale and its products: U.S. National Technical Information Service [Report] DE85006038/XAB, $14 \mathrm{p}$.

Georgia Mineral Newsletter, 1963, Notes on industrial minerals and ores: Georgia Mineral Newsletter, v. 16, nos, 1-2, p. 43-44.

Gerasimovsky, V.I., Volkov, V.P., Kogarko, L.N., and Polyakov, A.I, 1974, Kola Peninsula, in Sørensen, H., ed., The alkaline rocks: New York, John Wiley and Sons, p. 206-221.

Gerry, H.T., Amano, C.K., and Yodis, A.W., 1968, Process for producing iron-free aluminum nitrate solutions: U.S. Patent $3,383,166$, assigned to Allied Chemical Corporation.

Ghosh, S.K., 1986, Geology and geochemistry of Tertiary clay deposits in South Kerala: Geological Society of India Journal, v. 27, no. 4, p. 338-351.

Gildersleeve, Benjamin, and Whitlatch, G.I., 1944, High alumina clays in western Tennessee: Tennessee Valley Authority Open File Report, $230 \mathrm{p}$.

Glover, S.L., 1941, Clays and shales of Washington: Washington Division of Mines and Geology Bulletin 24, $368 \mathrm{p}$.

Gokcen, N.A., 1980, Partial pressures of gaseous $\mathrm{HCl}$ and $\mathrm{H}_{2} \mathrm{O}$ over aqueous solutions of $\mathrm{HCl}, \mathrm{AlCl}_{3}$, and $\mathrm{FeCl}_{3}$ : U.S. Bureau of Mines Report of Investigations 8456, $18 \mathrm{p}$.

1983, Rates of chlorination of aluminous resources: U.S. Bureau of Mines Information Circular 8952, $14 \mathrm{p}$.

Goldbery, R., and Loughnan, F.C., 1970, Dawsonite and nordstrandite in the Permian Berry Formation of the Sydney Basin, New South Wales: American Mineralogist, v. 55, nos. 3-4, p. 477-490.

Gooch, F.A., 1896, Process of producing hydrous chloride of aluminum: U.S. Patent 558,725, assigned to Waldo Foundry, Bridgeport, Conn.

Good, P.C., Butler, M.O., and Yerkes, L.A., 1966, Electrodeposition of aluminum from fused-salt electrolytes containing aluminum chloride: U.S. Bureau of Mines Report of Investigations 6785, $13 \mathrm{p}$.

Goodboy, K.P., 1976, Investigation of a sinter process for extraction of $\mathrm{Al}_{2} \mathrm{O}_{3}$ from coal wastes: Metallurgical Transactions $\mathrm{B}, \mathrm{v} .7 \mathrm{~B}$, no. 4 , p. $716-718$

Goodwin, R.W., 1978, Design concept for the recovery of fly ash constituents: Resource Recovery and Conservation, v. 3, no. 1, p. $61-68$.

Gordon, Mackenzie, Jr., Tracey, J.I., Jr., and Ellis, M.W., 1958, Geology of the Arkansas bauxite region: U.S. Geological Survey Professional Paper 299, 268 p.

Gould, C.N., and Fisher, C.A., 1901, The Dakota and Carboniferous clays of Nebraska: Nebraska State Board of Agriculture Annual Report for 1900 , p. 184-194.

Grametbaur, A.B., 1959, Selected bibliography of andalusite, kyanite, sillimanite, dumortierite, topaz, and pyrophyllite in the United States: U.S. Geological Survey Bulletin 1019-N, p. 973-1046.

Green, J.C., 1972, North Shore Volcanic Group, in Sims, P.K., and Morey, G.B., eds., Geology of Minnesota, a centennial volume: St. Paul, Minn., Minnesota Geological Survey, p. 294-332.

Greig, E.W., and Adams, M.J., 1977, Non-bauxite sources of alumina, in World aluminium survey: London, Metal Bulletin Ltd., p. $73-82$.

Gries, J.P., 1942, Economic possibilities of the Pierre Shale: South Dakota Geological Survey Report of Investigations 43, 79 p.
Grim, R.E., 1979, World-wide kaolin resources: Comité International pour L'Étude des Bauxites, de l'Alumine et de l'Aluminium Travaux, no. 15, p. 193-208.

Grim, R.E., and Allen, V.T., 1938, Petrology of the Pennsylvanian underclays of Illinois: Geological Society of America Bulletin, v. 49 , no. 10 , p. 1485-1514.

Grim, R.E., Machin, J.S., and Bradley, W.F., 1945, Amenability of various types of clay minerals to alumina extraction by the lime sinter and lime-soda sinter processes; Illinois Geological Survey Bulletin $69,77 \mathrm{p}$.

Groff, S.L., 1963, Sillimanite group of refractory minerals, in Mineral and water resources of Montana: U.S. Congress, 88th, 1st session, Senate Committee on Interior and Insular Affairs, Committee Print, p. 100-101.

Gross, R.O., 1965, Geology of Sierra Tinaja Pinta and Cornudas Station areas, northern Hudspeth County, Texas: Austin, Tex., University of Texas, unpub. M.A. thesis.

Grout, F.F., and Schwartz, G.M., 1939, The geology of the anorthosites of the Minnesota coast of Lake Superior: Minnesota Geological Survey Bulletin 28, 119 p.

Grzymek, Jerzy, 1976, Prof. Grzymek's self-disintegration method for the complex manufacture of aluminum oxide and portland cement, in Leavitt, S.R., ed., Light metals 1976-Proceedings of sessions, 105th AIME annual meeting, Las Vegas, Nevada: New York, American Institute of Mining, Metallurgical, and Petroleum Engineers, v. 2, p. 29-39.

1978, Fabrication liée d'oxyde d'aluminium et de ciment à partir de matières à faible teneur d'aluminium par la méthode de J. Grzymek: 4th International Congress for the Study of Bauxites, Alumina and Aluminum, Athens, October 9-12, 1978, Proceedings, v. 3 , p. $74-95$

Gulyás, Imre, and Vámos, György, 1976, Problems of the production of alumina and cement based on low-grade aluminum carriers, and the optimum solution of the problems: Hungarian Heavy Industries, v. 27 , no. 3 , p. $36-42$.

Gummer, W.K., 1952, Potential sources of alumina in Canada: Canadian Mining and Metallurgical Bulletin, no. 486, p. 605-609.

Gusev, V.I., Steshe, M.K., and Solodovnikov, P.A., 1933, Extraction of aluminum from the ash from Moscow coals: U.S.S.R. Patent 31,425 .

Haas, F.C., 1975, Alumina recovery from oil shale residue: U.S. Patent $3,859,413$, assigned to The Oil Shale Corporation (TOSCO).

Haas, F.C., and Atwood, M.T., 1975, Recovery of alumina from dawsonitic oil shales, in Gary. J.H., ed., Proceedings of the eighth Oil Shale Symposium: Colorado School of Mines Quarterly, v. 70, no. 3 , p. 95-107.

Hagner, A.F., 1951, Anorthosite of the Laramie Range, Albany County, Wyoming, as a possible source of alumina: Wyoming Geological Survey Bulletin 43, 15 p.

Hall, R.B., 1978, World nonbauxite aluminum resources-Alunite: U.S. Geological Survey Professional Paper 1076-A, 35 p.

Hall, R.N., and Haas, F.C., 1970, Recovery of sodium aluminate from dawsonite: U.S. Patent $3,510,255$, assigned to The Oil Shale Corporation (TOSCO).

Hamer, C.A., 1977, Extraction of alumina from Hat Creek material coal-ash: Canada Centre for Mineral and Energy Technology CANMET Report MRP/MSL 77-304(TR), $10 \mathrm{p}$.

Hamer, C.A., Quon, D.H.H., and Winer, A.A., 1978, Extraction of alumina from Canadian non-bauxite materials: 4th International Congress for the Study of Bauxites, Alumina and Aluminum, Athens, October 9-12, 1978, Proceedings, v. 3, p. 96-107.

Hansen, Miller, 1959, Clays of North Dakota as a potential source of alumina: North Dakota Geological Survey Report of Investigations $33,15 \mathrm{p}$. 
Harrington, J.F., Ward, D.E., and McKelvey, V.E., 1966, Sources of fertilizer minerals in South America-A preliminary study: U.S. Geological Survey Bulletin 1240, 66 p.

Harris, J.F., 1969, Kaolin deposits of Tanzania: International Geological Congress Report of the Twenty-Third Session, Czechoslovakia, 1968, Proceedings of Symposium I, Kaolin Deposits of the World, B-Oversea Countries, p. 75-78.

Harris, L.A., Ernst, W., and Tennery, V.J., 1971, A high-temperature $\mathrm{X}$-ray and thermal analysis study of synthetic dawsonite: American Mineralogist, v. 56, nos. 5-6, p. 1111-1113.

Haw, V.A., 1954, Kyanite in Canada: Canadian Mining and Metallurgical Bulletin, no. 501, p. 27-35.

Hayashi, Masami, 1982, Atmospheric pressure desilication of leach liquors from lime-sinter processing of anorthosite: U.S. Bureau of Mines Report of Investigations $8713,14 \mathrm{p}$.

Hearn, B.C., Jr., Pecora, W.T., and Swadley, W C, 1964, Geology of the Rattlesnake quadrangle, Bearpaw Mountains, Blaine County, Montana: U.S. Geological Survey Bulletin 1181-B, 66 p.

Heier, K.S., 1966, Some crystallo-chemical relations of nephelines and feldspars on Stjernöy, north Norway: Journal of Petrology, v. 7, no. 1 , p. 95-113.

Herz, Norman, 1968, The Roseland alkalic anorthosite massif, Virginia, in Isachsen, Y.W., ed., Origin of anorthosite and related rocks: New York State Museum and Science Service Memoir 18, p. 357-367.

Herz, Norman, and Force, E.R., 1984, Rock suites in Grenvillian terrane of the Roseland district, Virginia. Part 1, Lithologic relations. Part 2, Igneous and metamorphic petrology, in Bartholomew, M.J., ed., The Grenville event in the Appalachians and related topics: Geological Society of America Special Paper 194, p. 187-214.

Hetrick, J.H., 1982, Clay mineral distributions in the central Georgia kaolin district: Georgia Geologic Survey Open-File Report 82-4, $68 \mathrm{p}$.

Hetrick, J.H., and Friddell, M.S., 1982, A geologic study of the central Georgia kaolin district, Part I: Georgia Geologic Survey Open-File Report 83-1(1), $14 \mathrm{p}$.

1983a, A geologic study of the central Georgia kaolin district, Part II: Georgia Geologic Survey Open-File Report 83-1(2), 36 p. 1983b, A geologic study of the central Georgia kaolin district, Part III: Georgia Geologic Survey Open-File Report 83-1(3), 38 p.

Hewitt, D.F., 1957, Nepheline syenite [Ontario], in Canadian Institute of Mining and Metallurgy, Industrial Minerals Division, The geology of Canadian industrial mineral deposits: Toronto, Commonwealth Mining and Metallurgical Congress, 6th, 1957, p. 186-189.

1961, Nepheline syenite deposits of southern Ontario: Ontario Department of Mines [Annual Report] 1960, v. 69, pt. 8, 194 p.

Hietanen, A.M., 1956, Kyanite, andalusite, and sillimanite in the schist in Boehls Butte quadrangle, Idaho: American Mineralogist, v. 41, nos. 1-2, p. 1-27.

1963, Anorthosite and associated rocks in the Boehls Butte quadrangle and vicinity, Idaho: U.S. Geological Survey Professional Paper 344-B, 78 p.

Higbie, K.B., Sullivan, A.C., and Trought, M.E., 1963, Bauxite: U.S. Bureau of Mines Minerals Yearbook 1962, v. 1, p. 289-309.

Highley, D.E., 1975, Ball clay: Great Britain Institute of Geological Sciences, Mineral Resources Consultative Committee, Mineral Dossier 11, $32 \mathrm{p}$.

1982, Fire clay: Great Britain Institute of Geological Sciences, Mineral Resources Consultative Committee, Mineral Dossier 24, $72 \mathrm{p}$.

Hignett, T.P., 1947, Production of alumina from clay by a modified Pedersen process: Industrial and Engineering Chemistry, v. 39, p. $1052-1060$.
Hignett, T.P., Siegel, M.R., Kelso, T.M., and Meline, R.S., 1957, Utilization of high-alumina phosphate ore from the Florida leached-zone ore deposits: Tennessee Valley Authority Chemical Engineering Bulletin 3, $32 \mathrm{p}$.

Hiku, Namiyuki, 1947, Alumina from coal ash or clay: Japanese Patent 174,718, assigned to Asahi Chem. Industries Co.

Hillebrand, W.F., 1885, On zunyite and guitermanite, two new minerals from the Colorado: Colorado Scientific Society Proceedings, v. 1, p. 124-132.

Hite, R.J., 1969, Extracting aluminum in solution from oil shales: U.S. Patent 3,481,695, assigned to the Secretary of the Interior, $3 \mathrm{p}$.

Hite, R.J., and Dyni, J.R., 1967, Potential resources of dawsonite and nahcolite in the Piceance Creek basin, northwest Colorado, in Colorado School of Mines, Fourth symposium on oil shale: Colorado School of Mines Quarterly, v. 62, no. 3, p. 25-38.

Hittner, H.J., 1981, Hydrothermal alkaline process to extract alumina from anorthosite: Comité International pour l'Étude des Bauxites, de l'Alumine et de l'Aluminium Travaux, no. 16, p. 13-21.

Hodges, F.N., 1975, Petrology, chemistry and phase relations of the Sierra Prieta nepheline-analcime syenite intrusion, Diablo Plateau, Trans-Pecos, Texas: Austin, Tex., University of Texas, Ph.D. thesis, 209 p.

Hoffman, J.I., and others, 1946, Development of a hydrochloric acid process for the production of alumina from clay: U.S. National Bureau of Standards Journal of Research, v. 37, p. 409-428.

Holderreed, Francis, and Sullivan, R.E., 1960, Production of silica-free alumina: U.S. Patent 2,947,606, assigned to Anaconda Company.

Hollingsworth, J.S., 1967, Geology of the Wilson Springs vanadium deposits, Garland County, Arkansas, in Central Arkansas economic geology and petrology-Geological Society of America, Field Conference 1967, Guidebook: Little Rock, Ark., Arkansas Geological Commission, p. 22-24.

Holser, W.T., 1959, Trans-Pecos region, Texas and New Mexico, in Warner, L.A., Holser, W.T., Wilmarth, V.R., and Cameron, E.N., Occurrence of nonpegmatite beryllium in the United States: U.S. Geological Survey Professional Paper 318, p. 130-143.

Holzer, H.F., and Wieden, Paul, 1969, Kaolin deposits of Austria: International Geological Congress Report of the Twenty-Third Session, Czechoslovakia, 1968, Proceedings of Symposium I, Kaolin Deposits of the World, A-Europe, p. 25-32.

Hoover, K.V., Saylor, T.E., Lapham, D.M., and Tyrell, M.E., 1971, Properties and uses of Pennsylvania shales and clays, southeastern Pennsylvania: Pennsylvania Geological Survey Mineral Resources Report M-63, $321 \mathrm{p}$.

Hosterman, J.W., 1969a, Clay deposits of Spokane County, Washington: U.S. Geological Survey Bulletin 1270, $96 \mathrm{p}$.

1969b, White clay deposits near Mount Holly Springs, Cumberland County, Pennsylvania: U.S. Geological Survey Professional Paper 650-B, p. B66-B72.

1984, White clays of Pennsylvania: U.S. Geological Survey Bulletin 1558-D, $38 \mathrm{p}$.

Hosterman, J.W., and Dyni, J.R., 1972, Clay mineralogy of the Green River Formation, Piceance Creek basin, Colorado-A preliminary study: U.S. Geological Survey Professional Paper 800-D, p. D159-D163.

Hosterman, J.W., and others, 1987, Mineralogy and instrumental neutron activation analysis of seven National Bureau of Standards and three Instituto de Pesquisas Tecnológicas clay reference samples: U.S. Geological Survey Circular 957, $38 \mathrm{p}$

Hosterman, J.W., Scheid, V.E., Allen, V.T., and Sohn, I.G., 1960, Investigations of some clay deposits in Washington and Idaho: U.S. Geological Survey Bulletin 1091, 147 p.

Hsieh, H.P., 1981, Extraction of alumina from anthracite coal waste ashes in the Shamokin (PA) area: Washington, D.C., Appalachian 
Regional Commission, 43 p. (Prepared under contract 79-205, PA6291-79-1302-0614 by Alcoa.)

Hubacek, Jan, and Svejda, Zdenek, 1965 [Production of alumina from clays and ashes by sintering with limestones]: Hutnicke Listy, v. 20, no. 4, p. 275-281. (In Czech. Article not seen by authors; information from Chemical Abstracts, v. 62, abstract 14211d.)

Huber, Hans, and Rohlfs, H.A., 1957, Alkali phosphates and alumina from phosphates containing insoluble impurities: Federal Republic of Germany Patent 963,152, assigned to Chemische Werke Albert.

Huddle, J.W., and Patterson, S.H., 1961, Origin of Pennsylvanian underclay and related seat rocks: Geological Society of America Bulletin, v. 72, no. 11, p. 1643-1660.

Hudson, L.K., 1977, Aluminum from coal wastes?, in Rose, J.G., ed., Proceedings, Third Kentucky Coal Refuse Disposal and Utilization Seminar, May 11-12, 1977, Lexington, Ky.: Lexington, Ky., University of Kentucky, p. 79-82.

Hudson, L.K., Savage, K.I., and Stinson, J.M., Jr., 1977, Recovery of alumina from high-silica ore: U.S. Patent $4,044,095$, assigned to Aluminum Company of America, $7 \mathrm{p}$.

Hudson, L.K., and Swansiger, T.G., 1976, Recovery of sodium aluminate from high-silica aluminous materials: U.S. Patent 3,998,927, assigned to Aluminum Company of America, $6 \mathrm{p}$.

Huggins, C.W., and Green, T.E., 1973, Thermal decomposition of dawsonite: American Mineralogist, v. 58, nos. 5-6, p. 548-550.

Huggins, C.W., Green, T.E., and Turner, T.L., 1973, Evaluation of methods for determining naheolite and dawsonite in oil shales: U.S. Bureau of Mines Report of Investigations 7781, 21 p.

Hunter, D.B., Sawyer, D.L., Jr., and Turner, T.L., 1984, Alumina miniplant operations-Influence of reactor design on the attrition of calcined kaolin during $\mathrm{HCl}$ leaching: U.S. Bureau of Mines Report of Investigations 8877, $21 \mathrm{p}$.

Huska, P.A., and Meissner, H.P., 1974, Apparatus and method for providing a pure concentrated aqueous solution of aluminum nitrate: U.S. Patent 3,816,590, assigned to Arthur D. Little, Inc., $10 \mathrm{p}$.

Huska, P.A., Meissner, H.P., and Lamb, T.J., 1972, Apparatus and method for converting aluminum nitrate solutions to alpha alumina: U.S. Patent 3,647,373, assigned to Arthur D. Little, Inc.

Hussein, M.K., Kolta, G.A., and Ismail, A.K., 1974, Extraction of alumina from local non-bauxitic aluminium deposits: Chemie der Erde, v. 33, no. 1, p. 62-108.

Husted, J.E., 1974, Potential reserves of domestic nonbauxitic sources of aluminum, in Forberg, Helge, ed., Light metals-Proceedings of the 103d AIME annual meeting, 1974: New York, American Institute of Mining, Metallurgical, and Petroleum Engineers, v. 3, p. 691-711.

-1977 , An integrated aluminum industry for the Southeast-Concerns and outlook: Mining Congress Journal, v. 63, no. 9, p. 28-33. 1983, Characterization of Georgia kaolins as ores of aluminum: U.S. Bureau of Mines Open File Report 172-84, 178 p.

Hyde, R.W., and Margolin, S.V., 1971, Extracting pure alpha-alumina from clays: U.S. Patent 3,586,481, assigned to Arthur D. Little, Inc., $9 \mathrm{p}$.

Ikonnikov, A.B., 1984, Notes on geology of bauxite deposits in China, in Jacob, Leonard, Jr., ed., Bauxite, Proceedings of the 1984 Bauxite Symposium, Los Angeles, California, February 27-March 1, 1984: New York, American Institute of Mining, Metallurgical, and Petroleum Engineers, Society of Mining Engineers, p. 539-555.

Indian Bureau of Mines, 1975, Kyanite \& sillimanite, a market survey: Indian Bureau of Mines Market Survey Series MS 2, $123 \mathrm{p}$.

Industrial Minerals, 1977, Boliden joins LKAB in alum shale project: Industrial Minerals, no. 122, p. 12. -1979a, Industria Penoles SA, of Mexico, has recently acquired the use of USSR's VAMI process to produce alumina from domestic sources of nepheline syenite: Industrial Minerals, no. 143 , p. 59.

1979b, Norway-The hunt for bauxite alternatives: Industrial Minerals, no. 142 , p. 13 .

1985, Sillimanite minerals: Industrial Minerals, no. 208, p. 41-63.

Isachsen, Y.W., and Moxham, R.L., 1968, Chemical variation in plagioclase megacrysts from two vertical sections in the main Adirondack metanorthosite massif, in Isachsen, Y.W., ed., Origin of anorthosite and related rocks: New York State Museum and Science Service Memoir 18, p. 255-265.

Iverson, H.G., and Leitch, Harold, 1968, Alumina extraction by autoclave precipitation of basic sodium aluminum sulfate: U.S. Bureau of Mines Report of Investigations 7162, $27 \mathrm{p}$.

Jackson, Jesse, Jr., Huggins, C.W., and Ampian, S.G., 1972, Synthesis and characterization of dawsonite: U.S. Bureau of Mines Report of Investigations 7664, $14 \mathrm{p}$.

Jager, D.H. de, 1963, Sillimanite in Namaqualand-Review of reserves and report on some low-grade deposits: South Africa Geological Survey Bulletin 40, 42 p.

Jahns, R.H., 1938, Analcite-bearing intrusives from South Park, Colorado: American Journal of Science, 5th ser., v. 36, no. 211, p. 8-26.

Jambor, J.L., Plant, A.G., and Steacy, H.R., 1976, A dawsonitebearing silicocarbonatite sill from Montreal Island, Quebec: Canada Geological Survey Paper 76-1B, p. 357-362.

Jardin, Louis, 1959, Alumina and trisodium or tripotassium phosphate: French Patent 1,198,093, assigned to Aluminium Pechiney.

Jenkins, E.C., 1959, Hypabyssal rocks associated with the Christmas Mountains gabbro, Brewster County, Texas: Austin, Tex., University of Texas, unpub. M.A. thesis.

Jewett, J.M., Schoewe, W.H., and others, 1942, Kansas mineral resources for wartime industries: Kansas Geological Survey Bulletin 41 , pt. 3, p. 69-180.

Joesten, R., 1977, Mineralogical and chemical evolution of contaminated igneous rocks at a gabbro-limestone contact, Christmas Mountains, Big Bend region, Texas: Geological Society of America Bulletin, v. 88, p. 1515-1529.

Johnson, D.R., Young, N.B., and Smith, J.W., 1977, Thermal analysis on oil shale-Determination of potential oil yields and dawsonite, nahcolite and nordstrandite content: U.S. Department of Energy, Laramie Energy Research Center, Report of Investigation 77/6, $18 \mathrm{p}$.

Johnson, S.S., Denny, M.V., and LeVan, D.C., 1965, Analyses of clay, shale and related materials-Southwestern counties: Virginia Division of Mineral Resources, Mineral Resources Report 6, 210 p.

Johnson, S.S., and Tyrrell, M.E., 1967, Analyses of clay and related materials-Eastern counties: Virginia Division of Mineral Resources, Mineral Resources Report 8, $232 \mathrm{p}$.

Jonas, Oskar, Weger, Kurt, and Trebitz, Gotthard, 1931, Process of extracting clay and other aluminous raw materials: U.S. Patent $1,796,107$, assigned to I.G. Farbenind A.-G.

Jones, G.P., 1972, Origin, diagenesis and structure of bauxite deposits in southeast Alabama, in Puri, H.S., ed., Geology of phosphate, dolomite, limestone and clay deposits-Proceedings of the Seventh Forum on Geology of Industrial Minerals, Tampa, Fla., 1971: Florida Bureau of Geology Special Publication 17, p. 23-28.

Jones, W.R., Peoples, J.W., and Howland, A.L., 1960, Igneous and tectonic structures of the Stillwater Complex, Montana: U.S. Geological Survey Bulletin 1071-H, p. 281-340. 
Jourdan, Félix, 1926, Metodo per produrre della leucite, dell'analcime e da altri consimili minerali potassici o sodici, sala di potassio o di sodio: Italian Patent 15.05. (Reference from Abbruzzese and Rinelli, 1981.)

Kaiser Engineers Corporation, 1986, Recovery of metal oxides from fly ash including ash beneficiation products: Electric Power Research Institute Report CS-4384, 3 v.

Kalinkin, M.M., 1969 [Tectonics of the Kukisvumchorr-Yukspor and Razvumchorr apatite-nepheline bodies in Khibiny Mountains]: Geologiya Rudnykh Mestorozhdeniy, v. 11, no. 3, p. 64-72. (In Russian.)

Kamlet, Jonas, 1960, Ferruginous aluminum ores: U.S. Patent $2,964,383$, assigned to Reynolds Metals Company.

Kapolyi, Laszlo, and others, 1980, High-purity alumina and hydraulic cement: U.S. Patent 4,226,632, assigned to Tatabanyai Szenbanyak, $4 \mathrm{p}$.

Kapolyi, Laszlo, Vámos, Gyoergy, Riederauer, Sz., and Szépvölgyi, J., 1981, Complex processing of aluminium silicates by dry technology: Comité International pour l'Étude des Bauxites, de l'Alumine et de l'Aluminium Travaux, no. 16, p. 171-182.

Keith, M.L., 1939, Petrology of the alkaline intrusive at Blue Mountain, Ontario: Geological Society of America Bulletin, v. 50, no. 12, pt. 1, p. 1795-1826.

Kelly, D.H., and Bruen, C.P., 1971, Alumina of low residual nitrate content from basic aluminum nitrates: U.S. Patent 3,622,271, assigned to Reynolds Metals Company, $6 \mathrm{p}$.

Kelly, D.H., and Yodis, A.W., 1968, Process for decomposition of aluminum nitrate nonahydrates: U.S. Patent $3,366,446$, assigned to Allied Chemical Corporation.

Kelmers, A.D., Egan, B.Z., Seeley, F.G., and Campbell, G.D., 1981, Direct acid dissolution of aluminum and other metals from fly ash: American Institute of Mining, Metallurgical, and Petroleum Engineers, The Metallurgical Society, Preprint A81-24, $16 \mathrm{p}$.

Kerr, P.F., 1932, The occurrence of andalusite and related minerals at White Mountain, California: Economic Geology, v. 27, no. 7, p. 614-643.

Kerr, P.F., and Jenney, Phillip, 1935, The dumortierite-andalusite mineralization at Oreana, Nevada: Economic Geology, v. 30, no. 3, p. $287-300$

Kersen, J.F. van, 1956, Bauxite deposits in Suriname and Demerara (British Guiana): Leidse Geologische Mededelingen, v. 21, pt. 1, p. 249-375.

Kibby, R.M., 1977, Carbothermic reduction process: U.S. Patent 4,033,757, assigned to Reynolds Metals Company, 9 p.

Kim, B.H., and Ishikawa, Heishichi, 1974 [Changes in the properties of synthetic dawsonite by thermal treatments]: Nippon Kagaku Kaishi, no. 8, p. 1417-1420. (In Japanese; English summary.)

Kim, D.S., and Kim, W.M., 1969, Studies on the preparation of polyaluminum chloride: Kungnip Kongop Yon'guso Pogo (South Korea National Industrial Research Institute Reports), v. 19, p. 225-230.

Kim, N.J., and Kang, P.C., 1965 [Geological map of Chingyo sheet and explanatory text in a separate booklet]: [South] Korea Geological Survey Sheet 6719-II, 33 p., scale 1:50,000. (In Korean; 10-p. English version of the explanatory text included in the booklet.)

Kimbell, C.L., 1967, The mineral industry of Argentina: U.S. Bureau of Mines Minerals Yearbook 1965, v. 4, p. 139-155.

Kinney, E.D., 1943, A process for extracting alumina from Kansas clay: Kansas Geological Survey Bulletin 47, pt. 4, p. 113-136.

Kirby, D.E., Singleton, E.L., and Sullivan, T.A., 1970, Electrowinning aluminum from aluminum chloride, operation of a singlecompartment cell: U.S. Bureau of Mines Report of Investigations $7353,24 \mathrm{p}$.
Kirby, R.C., and Barclay, J.A., 1981, Alumina from nonbauxitic resources: Comité International pour l'Étude des Bauxites, de l'Alumine et de l'Aluminium Travaux, no. 16, p, 1-12.

Kirpal', G.R., and Tenyakov, V.A., 1974 [Deposits of aluminium], in Smirnov, V.I., ed. [Ore deposits of the USSR, Volume 1]: Moscow, Nedra, p. 252-324. (English translation by D.A. Brown published in 1977 by Pitman Publishing, Belmont, Calif., 352 p.)

Klinefelter, T.A., and Cooper, J.D., 1961, Kyanite, a materials survey: U.S. Bureau of Mines Information Circular 8040, 55 p.

Knox, C.C., 1948, Investigation of Kiowa County clays, Kiowa County, Okla.: U.S. Bureau of Mines Report of Investigations 4329, $18 \mathrm{p}$.

Ko, H.C., Landsberg, Arne, and Henry, J.L., 1983, The vapor-liquid equilibria of the aluminum chloride-ferric chloride system: Metallurgical Transactions B, v. 14B, p. 301-303.

Korshunov, V.I., and Shmuk, E.I., 1957 [Aluminum oxide extraction from the tailings of coal flotation]: Izvestiya Akademii Nauk SSSR Otdelenie Tekhnischeskikh Nauk, 1957, no. 2, p. 153-155. (In Russian. Article not seen by authors; information from Chemical Abstracts, 1957, v. 51, abstract 15077g.)

Kostyun, V.P., 1975 [Pseudoleucite as a complex mineral raw material], in Problemy nefelinovogo syr'ya: Moscow, Akademiya Nauk SSSR Nauchnyi Sovet po Rudoobrazovaniyu, p. 33-34. (In Russian. Article not seen by authors; information from Chemical Abstracts, 1976, v. 85, abstract 127248x.)

Kramer, D.A., 1983, Economic and technical evaluation of the sulfurous acid-caustic purification process for producing alumina from kaolinitic clay: U.S. Bureau of Mines Information Circular 8959, $26 \mathrm{p}$.

Kramer, D.A., and Peters, F.A., 1983, Cost estimate of the Bayer process for producing alumina-Based on 1982 equipment prices: U.S. Bureau of Mines Information Circular 8958, $20 \mathrm{p}$.

Kurtz, H.F., 1972, Bauxite: U.S. Bureau of Mines Minerals Yearbook 1970 , v. 1, p. 211-223.

1976, Bauxite: U.S. Bureau of Mines Minerals Yearbook 1974 v. 1 , p. 199-216.

1978, Bauxite and alumina: U.S. Bureau of Mines Minerals Yearbook 1976, v. 1, p. 197-211.

Kužvart, Miloš, 1969a, Kaolin deposits of Czechoslovakia: International Geological Congress Report of the Twenty-Third Session, Czechoslovakia, 1968, Proceedings of Symposium I, Kaolin Deposits of the World, A-Europe, p. 47-73.

1969b, Review of kaolin deposits of Asia, Africa, America and Australia: International Geological Congress Report of the Twenty-Third Session, Czechoslovakia, 1968, Proceedings of Symposium I, Kaolin Deposits of the World, B-Oversea Countries, p. $7-13$.

Kwon, S.W., Kim, B.H., and Ishikawa, Heishichi, 1971 [Conditions of formation of dawsonite and its crystal structure]: Kogyo Kagaku Zasshi, v. 74, no. 12, p. 2411-2415. (In Japanese; English summary.)

Laist, Fredrick, 1960a, Production of silica-free alumina: U.S. Patent 2,947,604, assigned to Anaconda Company.

$1960 \mathrm{~b}$, Production of silica-free alumina: U.S. Patent 2,947,605, assigned to Anaconda Company.

Lamar, J.E., 1948, Clays and shales of extreme southern Illinois: Illinois Geological Survey Report of Investigations 128, $107 \mathrm{p}$.

Landi, M.F., 1975, Alumina production from leucite alkali sinter process in pilot plant: American Institute of Mining, Metallurgical, and Petroleum Engineers, The Metallurgical Society, Preprint A75-68, p. 225-231. (In English, Russian, and Italian.)

-1981 , Study on the behaviour of alkali aluminium silicates in the carbothermic reduction process: Comité International pour l'Étude des Bauxites, de l'Alumine et de l'Aluminium Travaux, no. 16 , p. $53-63$. 
Landi, M.F., Da Roit, S., Montesi, S., and Piras, L., 1984, The production of raw $\mathrm{Al} / \mathrm{Si}$ alloys from Italian leucitic minerals by a direct carbothermic process. Experiments and results on a pilot plant, in McGeer, J.P., ed., Light metals 1984-Proceedings of the technical sessions ***, 113th [AIME] annual meeting, Los Angeles, California, February 27-March 1, 1984: New York, American Institute of Mining, Metallurgical, and Petroleum Engineers, p. 601-618.

Landsberg, Arne, 1975, Chlorination kinetics of aluminum bearing minerals: Metallurgical Transactions B, v. 6B, p. 207-214.

1977, Some factors affecting the chlorination of kaolinic clay: Metallurgical Transactions B, v. 8B, p. 435-441.

1983, Aluminum from domestic clay via a chloride process - The state-of-the-art: U.S. Bureau of Mines Information Circular 8923, $15 \mathrm{p}$.

Landsberg, Arne, and Wilson, R.D., 1984, A study of the mechanisms of the salt catalyzed carbochlorination of kaolin: Metallurgical Transactions B, v. 15B, p. $695-700$.

Lang, W.B., and others, 1940, Clay investigations in the Southern States, 1934-35: U.S. Geological Survey Bulletin 901, 346 p.

Lang, W.B., Warren, W.C., Thompson, R.M., and Overstreet, E.F., 1965, Bauxite and kaolin deposits of the Irwinton district, Georgia: U.S. Geological Survey Bulletin 1199-J, 26 p.

Latrilhe, Edmond, 1959, Contribution à l'étude des phosphates alumineux de la région de Thiès (Sénégal): French West Africa Service de Géologie et de Prospection Minière Bulletin 25, 83 p.

Laurin, A.-F., 1965, Gouin Reservoir basin, Abitibi-East and Laviolette Counties-A geological outline: Quebec Department of Natural Resources Geological Report 130, $14 \mathrm{p}$.

Lawrence, W.F., and Coalgate, Jerold, 1973, Technical and economic evaluation of dewatering, production of structural materials, and recovery of alumina from limestone modified flyash produced by limestone, wet-scrubbing process: Morgantown, West Virginia University Coal Research Bureau. (Prepared under contract EHS D-7-11 from the U.S. Environmental Protection Agency.)

Lazarenko, E.A., and Mel'nikov, V.S., 1969 [Dawsonite from Transcarpathia]: Mineralogicheskiy Sbornik (Lvov), no. 23, pt. 3, p. 337-340. (In Russian; English summary.)

Leighton, Henry, 1941, Clay and shale resources in Pennsylvania: Pennsylvania Geological Survey, 4th ser., Bulletin M-23, 245 p.

Letteney, C.D., 1968, The anorthosite-norite-charnockite series of the Thirteenth Lake dome, south-central Adirondacks, in Isachsen, Y.W., ed., Origin of anorthosite and related rocks: New York State Museum and Science Service Memoir 18, p. 329-342.

Light Metal Age, 1961, Alumina from clay: Light Metal Age, April, p. 8.

Lin, C.H., and Chen, D.S., 1978 [Extraction of alumina from domestic aluminum-containing minerals and new energy-saving methods to produce aluminum]: K'o Hsueh Fa Chan Yueh K'an, v. 6, no. 12, p. 905-927. (In Chinese. Article not seen by authors; information from Chemical Abstracts, 1979, v. 90, abstract 155048d, and 1980, v. 92 , abstract $96199 \mathrm{v}$.)

Lippert, H.J., and others, 1969, Die Kaolinlagerstatten der Bundesrepublik Deutschland: International Geological Congress Report of the Twenty-Third Session, Czechoslovakia, 1968, Proceedings of Symposium I, Kaolin Deposits of the World, A-Europe, p. 85-105.

Lippman, Alfred, and Sebenik, R.F., 1978, Process for the production of aluminum chloride and related products: U.S. Patent $4,083,923$, assigned to Toth Aluminum Corporation.

Lippman, Alfred, Toth, Charles, and Sebenik, R.F., 1976, Carbochlorination of aluminum phosphate: U.S. Patent $3,935,297$, assigned to Toth Aluminum Corporation, $7 \mathrm{p}$.

Livingston, V.E., Jr., 1971, Geology and mineral resources of King County, Washington: Washington Division of Mines and Geology Bulletin 63, 200 p.
Logomerac, V.G., and Črnko, J.J., 1981, Occurrences of rare-earth elements in leucite rocks near Gnjilane (Kosovo, Yugoslavia), and possibilities of their recovery: Comité International pour l'Étude des Bauxites, de l'Alumine et de l'Aluminium Travaux, no. 16, p. 201-208.

Lonsdale, J.T., 1940, Igneous rocks of the Terlingua-Solitario region, Texas: Geological Society of America Bulletin, v. 51, no. 10, p. $1539-1636$.

Losche, C.K., McCracken, R.J., and Davey, C.B., 1970, Soils of steeply sloping landscapes in the southern Appalachian Mountains: Soil Science Society of America Proceedings, v. 34, no. 3, p. 473-478.

Loughnan, F.C., and Goldbery, R., 1972, Dawsonite and analcite in the Singleton coal measures of the Sydney basin: American Mineralogist, v. 57, nos. 9-10, p. 1437-1447.

Loughnan, F.C., and See, G.T., 1967, Dawsonite in the Greta coal measures at Muswellbrook, New South Wales: American Mineralogist, v. 52, nos. 7-8, p. 1216-1219.

Lundquist, R.V., 1963, Recovery of alumina from anorthosite, San Gabriel Mountains, California, using the lime soda sinter process, with a section on Geology, by G.B. Oakeshott: U.S. Bureau of Mines Report of Investigations 6288, $12 \mathrm{p}$.

MacMillan, R.T., and Jackson, Jesse, Jr., 1972, Producing solutions of high alumina concentration by alkali extraction of aluminumcontaining oil shale: U.S. Patent $3,700,766,3$ p.

Mah, A.D., 1982, Chemical equilibria in chlorination of clay: U.S. Bureau of Mines Report of Investigations 8696, $43 \mathrm{p}$.

Malamphy, M.C., and others, 1948, Investigation of Arkansas bauxite, Volumes I-XVIII: U.S. Bureau of Mines Report of Investigations $4251-4268$.

Manolov, N., Karanov, Khr., Karavasteva, O., and Tsonev, V., 1969 [Kaolin deposits of Bulgaria]: International Geological Congress Report of the Twenty-Third Session, Czechoslovakia, 1968, Proceedings of Symposium I, Kaolin Deposits of the World, A-Europe, p. 33-46. (In Bulgarian; English summary.)

Manos, Anthony, 1978, Industrial minerals of Rhodesia: Industrial Minerals, no. 126, p. 93-107.

Marburg, E.C., 1930, Alumina from clay: U.S. Patent 1,778,083, assigned to I.G. Farbenind A.-G.

March, C.C., 1943a, Alumina from clays. Part I, Beneficiation of Washington residual clays to increase the alumina content: Washington State Mining Experiment Station Bulletin E-3, 13 p. 1943b, Alumina from clays. Pt. II, Investigations into methods of producing pure alumina from kaolin by sulphate leaching: Washington State Mining Experiment Station Bulletin E-4, 40 p.

Margolin, S.V., and Hyde, R.W., 1974, The A.D.L. [Arthur D. Little] nitric acid process for recovery of alumina from aluminum-bearing minerals, in Forberg, Helge, ed., Light metals-Proceedings of the 103d AIME annual meeting, 1974: New York, American Institute of Mining, Metallurgical, and Petroleum Engineers, v. 2, p. $469-487$.

Mark, Helen, 1963, High-alumina kaolinitic clay in the United States, exclusive of Alaska and Hawaii: U.S. Geological Survey Mineral Resource Map MR-37, scale 1:3,168,000.

Marks, J.H., and Jackson, K.C., 1975, Trace elements in a syenite and minor syenite dikes from one outcrop; Bauxite, Arkansas [abs.]: Geological Society of America Abstracts with Programs, v. 7, no. 2, p. 213-214.

Marsh, S.P., and Sheridan, D.M., 1976, Rutile in Precambrian sillimanite-quartz gneiss and related rocks, east-central Front Range, Colorado: U.S. Geological Survey Professional Paper 959-G, $17 \mathrm{p}$.

Martín Vivaldi, L., 1969, Kaolin deposits of Spain: International Geological Congress Report of the Twenty-Third Session, Czech- 
oslovakia, 1968, Proceedings of Symposium I, Kaolin Deposits of the World, A-Europe, p. 225-261.

Massacci, Paolo, 1978, Mining and mineralurgical problems related to the exploitation of raw materials substitutive of bauxite: 4th International Congress for the Study of Bauxites, Alumina and Aluminum, Athens, October 9-12, 1978, Proceedings, v. 2, p. 553-570.

Massacci, Paolo, Pinzari, M., and Sciotti, M., 1981, The Latium "leucitic tuffs" as a source for the extraction of alumina or aluminium: Comité International pour l'Étude des Bauxites, de l'Alumine et de l'Aluminium Travaux, no. 16, p. 39-51.

Mathias, M., 1974, Alkaline rocks of southern Africa, in Sørensen, H., ed., The alkaline rocks: New York, John Wiley and Sons, p. 189-202.

Maurel, Pierre, and Duhart, Pierre, 1971, Process for acid treatment of aluminous ores for the recovery of alumina: U.S. Patent $3,620,671$, assigned to Aluminium Pechiney.

-1975, Process for the continuous acid treatment of crude clay and schist: U.S. Patent 3,862,293, assigned to Aluminium Pechiney.

Maxey, L.R., 1976, Petrology and geochemistry of the Beemerville carbonatite-alkalic rock complex, New Jersey: Geological Society of America Bulletin, v. 87, no. 11, p. 1551-1559.

May, J.T., and Seidel, D.C., 1976, Recovering aluminum from a copper leach liquor by ion exchange, an exploratory study: U.S. Bureau of Mines Report of Investigations 8174, $22 \mathrm{p}$.

Maysilles, J.H., Traut, D.E., and Sawyer, D.L., Jr., 1982, Aluminum chloride hexahydrate crystallization by $\mathrm{HCl}$ gas sparging: U.S. Bureau of Mines Report of Investigations 8590, 38 p.

McAllister, J.F., 1952, Rocks and structure of the Quartz Spring area, northern Panamint Range, California: California Division of Mines Special Report 25, $38 \mathrm{p}$.

McCawley, F.X., and Stephenson, P.A., 1984, Aluminum: U.S. Bureau of Mines Minerals Yearbook 1983, v. 1, p. 81-102.

MeCracken, R.J., and others, 1971, Soils of the Hayesville, Cecil, and Pacolet series in the southern Appalachian and Piedmont regions of the United States: North Carolina State University, North Carolina Agriculture Experiment Station, Southern Cooperative Series, Bulletin 157.

MeCulloch, H.W., 1967, A review of the investigations into the possibility of producing alumina and aluminum from South African ores: South Africa National Institute for Metallurgy, Research Report no. $143,57 \mathrm{p}$.

McCullough, R.F., 1959, Processing of high-aluminum phosphate ores: U.S. Patent 2,905,526, assigned to U.S. Atomic Energy Commission.

McCullough, R.F., and Adams, J.B., 1959, Recovery of alumina, uranium oxide, and phosphates from low-grade phosphate ore: U.S. Patent $2,894,809$, assigned to U.S. Atomic Energy Commission.

McKelvey, V.E., and others, 1953, Domestic phosphate deposits, in Pierre, W.H., and Norman, A.G., eds., Soil and fertilizer phosphorus in crop nutrition: New York, Academic Press, p. 347-376.

McQueen, H.S., 1943, Geology of the fire clay districts of east central Missouri: Missouri Geological Survey and Water Resources, 2d ser. [Reports], v. 28, 250 p.

Messner, Georg, 1976, Method for the fabrication of pure alumina from alumina- and silica-containing raw materials by leaching with hydrochloric acid: U.S. Patent 3,959,438, 11 p.

Metals Sourcebook, 1974, Aluminum: Metals Sourcebook, v. 2, no. 4, p. 4.

Middelhoek, S., Santing, G., and Dost, N., 1977, Electric process: U.S. Patent 4,049,425, assigned to Shell International.

Mikhaylov, B.M., and others, 1977, Geological prerequisites for expanding the raw-material base of the aluminum industry in
Siberia and the Far East: International Geology Review, v. 19, no. 10, p. 1216-1224. (Translated from Sovetskaya Geologiya, 1976 , no. 7 , p. 3-14.)

Miller, E., Call, G.E., Haskett, P.R., and Nicks, L.J., 1983, Fluidizedbed decomposition of aluminum chloride hexahydrate, in Adkins, E.M., ed., Light metals 1983-Proceedings of technical sessions ***, 112th AIME annual meeting, Atlanta, Georgia, March 6-10, 1983: New York, American Institute of Mining, Metallurgical, and Petroleum Engineers, p. 253-271.

Miller, R.H., 1959, Mineral resources of South Dakota: Pierre, South Dakota Industrial Development Expansion Agency, $96 \mathrm{p}$.

Miller, T.P., 1972, Potassium-rich alkaline intrusive rocks of western Alaska: Geological Society of America Bulletin, v. 83, no. 7, p. 2111-2128.

Milliken, T.H., Jr., 1957, Alumina and phosphates from phosphate rock: U.S. Patent 2,817,578, assigned to Houdry Process Corporation.

Milton, Charles, Dwornik, E.J., and Finkelman, R.B., 1975, Nordstrandite, $\mathrm{Al}(\mathrm{OH})_{3}$, from the Green River Formation in Rio Blanco County, Colorado: American Mineralogist, v. 60, nos. 3-4, p. 285-291.

Milton, Charles, and Eugster, H.P., 1959, Mineral assemblages of the Green River Formation, in Abelson, P.H., ed., Researches in geochemistry: New York, John Wiley and Sons, p. 118-150.

Mining Annual Review, 1971, [Aluminum in] Argentina: Mining Annual Review, 1971, p. 78.

1988, Senegambia: Mining Annual Review, 1988, p. 405-406.

Mining Engineering, 1963, Anaconda develops new alumina process: Mining Engineering, v. 15, no. 9, p. 9.

-1977 , Boliden, LKAB join forces to extract Swedish alum shales: Mining Engineering, v. 29, no. 12, p. 14-15.

Mining Journal, 1959, $\$ 500,000$ alumina pilot plant: Mining Journal, v. 253 , no. 6478 , p. 368.

1964, Aluminium from clay: Mining Journal, v. 262, no. 6703, p. 99 .

1965, Aluminium from clay: Mining Journal, v. 264, no. 6771, p. $425-426$.

1971, Bauxite-free alumina: Mining Journal, v. 276, no. 7082, p. $384-385$.

-1977, Georgia-Kaolin interest: Mining Journal, v. 289, no. 7417 , p. 315.

-1981, Japan-New aluminium process studied: Mining Journal, v. 296 , no. 7610 , p. 497.

Mining World, 1953, Florida's phosphate beds may become new source of aluminum raw material: Mining World, v. 15 , no. 6 , p. 87.

Morrison, E.R., 1976, Some aluminium minerals in Rhodesia, with a section on Bauxite, by P.L.C. Grubb: Rhodesia Geological Survey Mineral Resources Series, no. 18, 41 p.

Moses, J.H., and Michell, W.D., 1963, Bauxite deposits of British Guiana and Surinam in relation to underlying unconsolidated sediments suggesting two-step origin: Economic Geology, v. 58, no. 2 , p. $250-262$.

Moyd, L.S., 1949, Petrology of the nepheline and corundum rocks of southeastern Ontario: American Mineralogist, v. 34, nos. 9-10, p. 736-751.

Mullens, M.C., 1973, Bibliography of the geology of the Green River Formation, Colorado, Utah, and Wyoming, to March 1, 1973: U.S. Geological Survey Circular 675, $20 \mathrm{p}$.

Müller-Vonmoos, Max, and Bach, R., 1969, Thermoanalytic-mass spectrometrical investigation of an oil shale containing dawsonite, in Schwenker, R.F., Jr., and Garn, P.D., eds., Thermal analysisProceedings of the Second International Conference on Thermal Analysis, held at Holy Cross College, Worcester, Massachusetts, August 18-23, 1968: New York, Academic Press, v. 2, p. $1229-1238$ 
Munsell Color Company, 1929-1960, Munsell soil color charts: Baltimore, Md.

Munyan, A.C., 1938, Supplement to sedimentary kaolins of Georgia: Georgia Geological Survey Bulletin 44-A, 42 p.

Murray, H.H., 1984, Geology, mineralogy, and geochemistry of kaolin at Weipa, Queensland, Australia [abs.]: Clay Minerals Society, 21st Annual Meeting, Baton Rouge, La., 1984, Programs with Abstracts, p. 87.

Murray, H.H., and Patterson, S.H., 1976, Kaolin, ball-clay, and fire-clay deposits in the United States - Their ages and origins, in Bailey, S.W., ed., Proceedings of the International Clay Conference, 1975, Mexico City, Mexico: Wilmette, Ill., Applied Publishing Ltd., p. 511-520.

Murray, H.H., and Smith, John M., 1973, The geology and mineralogy of the Grahamstown, South Africa, kaolin deposit [abs.]: Clay Minerals Conference, 22d, Program and Abstracts, p. 48.

Murtha, M.J., and Burnet, George, 1976, Recovery of alumina from coal fly ash by high-temperature chlorination: Iowa Academy of Sciences Proceedings, v. 83, no. 4, p. 125-129.

-1978, Power plant fly ash as a source of alumina, in Aleshin, Eugene, ed., Proceedings of the Sixth Mineral Waste Utilization Symposium, cosponsored by the U.S. Bureau of Mines and ITT Research Institute, 2-3 May 1978, Chicago, Illinois: Chicago, ITT Research Institute, p. 334-339.

1979, Processes to increase utilization of power solid wastes, in Solid waste research and development needs for emerging coal technologies [workshop proceedings]: New York, American Society of Civil Engineers, p. 135-152.

National Materials Advisory Board, 1970, Processes for extracting alumina from nonbauxite ores: National Academy of Sciences Publication NMAB-278, 88 p.

National Research Council, Committee on Accessory Elements, 1979, Redistribution of accessory elements in mining and mineral processing. Part II, Uranium, phosphate, and alumina: Washington, D.C., National Academy of Sciences, $169 \mathrm{p}$.

Neilson, J.M., 1953, Albanel area, Mistassini Territory: Quebec Department of Mines, Geological Surveys Branch, Geological Report 53, $35 \mathrm{p}$

Nemecz, Erno, and others, 1976a, Process for producing aluminum trichloride: U.S. Patent 3,956,454, assigned to Toth Aluminum Corporation.

1976b, Production of aluminum chloride from raw materials containing coal: U.S. Patent 3,950,485, assigned to Toth Aluminum Corporation.

Newhouse, W.H., and Hagner, A.F., 1957, Geologic map of anorthosite areas, southern part of Laramie Range, Wyoming: U.S. Geological Survey Mineral Investigations Field Studies Map MF-119, scale 1:63,360.

Nichols, R.L., 1944, Preliminary report on the Molalla high-alumina clay deposit near Molalla, Clackamas County, Oregon: U.S. Geological Survey Open-File Report, $24 \mathrm{p}$.

-1945, Preliminary report on the Cowlitz high-alumina clay deposit near Castle Rock, Cowlitz County, Washington: U.S. Geological Survey Open-File Report, $18 \mathrm{p}$.

1946, Preliminary report on the King County, Washington, high-alumina clay deposits: U.S. Geological Survey Open-File Report, $41 \mathrm{p}$.

Nielsen, Irvin, 1969, The amazing Piceance mineral suite and its industrial potential for energy-oil-metals-chemicals: Engineering and Mining Journal, v. 170, no. 1, p. 57-60.

Nowak, Zygfryd, 1974, Iron and alumina extraction from powerplant fly ash in Poland, in Faber, J.H., Eckard, W.E., and Spencer, J.D., comps., Ash utilization, Proceedings [of the] Third Interna- tional Ash Utilization Symposium, ***, Pittsburgh, Pa., March 13-14, 1973: U.S. Bureau of Mines Information Circular 8640, p. 224-230.

Nozhkin, A.D., and Cherepnin, V.K., 1967, First finding of nepheline rocks in northern Yenisey Range: International Geology Review, v. 9, no. 9, p. 1177-1179. (Translated from Geologiya i Geofizika, 1966, no. 11, p. 104-106.)

Nunn, R.F., Chuberka, P., Malm, L., and San Jose, A.V., 1979, The comparative economics of producing alumina from U.S. nonbauxitic ores, in Peterson, W.S., ed., Light metals 1979-Proceedings of technical sessions ***, 108th AIME annual meeting in New Orleans, Louisiana, February 18-22, 1979: New York, American Institute of Mining, Metallurgical, and Petroleum Engineers, p. 283-334.

Nurmagambetov, Kh. N., and others, 1977 [Pilot plant testing of ash concentrate processing by sintering]: Metallurgia i Metallovedenie (Alma-Ata), v. 6, p. 58-66. (In Russian.)

Oberg, F.N., and Le Baron, I.M., 1959, Concentrating phosphate ores with recovery of alumina and uranium oxide: U.S. Patent 2,868,618, assigned to U.S. Atomic Energy Commission.

Odom, I.E., and Parham, W.E., 1968, Petrography of Pennsylvanian underclays in Illinois and their application to some mineral industries: Illinois Geological Survey Circular 429, $36 \mathrm{p}$.

Olive, W.W., and Finch, W.I., 1969, Stratigraphic and mineralogic relations and ceramic properties of clay deposits of Eocene age in the Jackson Purchase region, Kentucky, and in adjacent parts of Tennessee: U.S. Geological Survey Bulletin 1282, 35 p.

Olmsted, J.F., 1968, Petrology of the Mineral Lake intrusion, northwestern Wisconsin, in Isachsen, Y.W., ed., Origin of anorthosite and related rocks: New York State Museum and Science Service Memoir 18, p. 149-161.

Olsen, R.S., and others, 1982, Effects of feed preparation on $\mathrm{HCl}$ leaching of calcined kaolinitic clay to recover alumina: U.S. Bureau of Mines Report of Investigations 8618, $24 \mathrm{p}$.

1983a, Factors affecting the preparation of misted clay feed and solids-liquid separation after HCl leaching: U.S. Bureau of Mines Report of Investigations 8772, $25 \mathrm{p}$.

1983b, Leaching aluminum from calcined kaolinitic clay with nitric acid: U.S. Bureau of Mines Report of Investigations 8834, $14 \mathrm{p}$.

-1983c, Leaching rates for the $\mathrm{HCl}$ extraction of aluminum from calcined kaolinitic clay: U.S. Bureau of Mines Report of Investigations $8744,11 \mathrm{p}$.

O'Neill, B.J., Jr., and others, 1965, Properties and uses of Pennsylvania shales and clays: Pennsylvania Geological Survey Bulletin M51 (Mineral Resources Report), 448 p.

O'Neill, J.J., 1914, St. Hilaire (Beloeil) and Rougemont Mountains, Quebec: Canada Geological Survey Memoir 13, 108 p.

Osborne, F.F., 1935, Labelle-L'Annonciation map area: Quebec Bureau of Mines Annual Report, 1934, pt. E, 52 p.

Ostojic, Slavko, 1980, Aluminium from non-bauxite sources: International Bauxite Association Quarterly Review, v. 6, no. 2, p. 28-42.

Overstreet, W.C., 1961, Saprolite, in Yearbook of science and technology: New York, McGraw-Hill Book Co., p. 447-448.

Overstreet, W.C., and Griffitts, W.R., 1955, Inner Piedmont belt, in Russell, R.J., ed., Guides to southeastern geology-Prepared for the 1955 annual meeting of the Geological Society of America and associated societies: New York, Geological Society of America, p. $549-577$.

Overstreet, W.C., Yates, R.G., and Griffitts, W.R., 1963, Heavy minerals in the saprolite of the crystalline rocks in the Shelby quadrangle, North Carolina: U.S. Geological Survey Bulletin 1162-F, 31 p. 
Paiva, Glycon de, Capper Alves de Souza, Henrique, and Abreu, S.F., 1937, Ouro e bauxita na região do Gurupy (Pará e Maranhão): Brazil Serviço de Fomento da Produção Mineral Boletim 13, 172 p.

Papadopoulos, M.N., and Ueber, R.C., 1972, Producing oil from an oil shale formation containing nahcolite and dawsonite: U.S. Patent $3,700,280$, assigned to Shell Oil Company, $4 \mathrm{p}$.

Parham, W.E., 1970, Clay mineralogy and geology of Minnesota's kaolin clays: Minnesota Geological Survey Special Publication Series SP-10, $142 \mathrm{p}$.

Parker, J.M., III, 1946, Residual kaolin deposits of the Spruce Pine district, North Carolina: North Carolina Department of Conservation and Development, Division of Mineral Resources, Bulletin $48,45 \mathrm{p}$.

Parker, R.L., and Calkins, J.A., 1964, Geology of the Curlew quadrangle, Ferry County, Washington: U.S. Geological Survey Bulletin $1169,95 \mathrm{p}$.

Parker, R.L., and Hildebrand, F.A., 1963, Preliminary report on alkalic intrusive rocks in the northern Wet Mountains, Colorado: U.S. Geological Survey Professional Paper 450-E, p. E8-E10.

Parkman, H.C., 1935, Sulphuric acid leaching of Washington clays for the production of alumina and aluminum metal: The State College of Washington, School of Mines and Geology, and the State Metallurgical Research Laboratory, Bulletin E, 51 p.

Patterson, S.H., 1967, Bauxite reserves and potential aluminum resources of the world: U.S. Geological Survey Bulletin 1228, $176 \mathrm{p}$.

-1971, Investigations of ferruginous bauxite and other mineral resources on Kauai and a reconnaissance of ferruginous bauxite deposits on Maui, Hawaii: U.S. Geological Survey Professional Paper 656, 74 p.

Patterson, S.H., and Dyni, J.R., 1973, Aluminum and bauxite, in Brobst, D.A., and Pratt, W.P., eds., United States mineral resources: U.S. Geological Survey Professional Paper 820, p. $35-43$.

Patterson, S.H., and Hosterman, J.W., 1962, Geology and refractory clay deposits of the Haldeman and Wrigley quadrangles, Kentucky: U.S. Geological Survey Bulletin 1122-F, 113 p.

Patterson, S.H., Kurtz, H.F., Olson, J.C., and Neeley, C.L., 1986, World bauxite resources: U.S. Geological Survey Professional Paper 1076-B, $151 \mathrm{p}$.

Patterson, S.H., and Murray, H.H., 1984, Kaolin, refractory clay, ball clay, and halloysite in North America, Hawaii, and the Caribbean region: U.S. Geological Survey Professional Paper 1306, 56 p.

Patton, W.W., Jr., and Miller, T.P., 1968, Regional geologic map of the Selawik and southeastern Baird Mountains quadrangles, Alaska: U.S. Geological Survey Miscellaneous Geologic Investigations Map I-530, scale 1:250,000.

Paulin, A., Jobson, B.A., and Vukčević, Slobodanka, 1981, Chloration of aluminous materials in fluidized beds: Comité International pour l'Étude des Bauxites de l'Alumine et de l'Aluminium Travaux, no. 16 , p. 161-170.

Pecora, W.T., 1942, Nepheline syenite pegmatites, Rocky Boy stock, Bearpaw Mountains, Montana: American Mineralogist, v. 27, no. 6, p. 397-424.

Pedersen, H., 1927, [Process of manufacturing] aluminum hydroxide: U.S. Patent $1,618,105$.

Pennsylvania Geological Survey, 1964, Map of the Mercer clay and adjacent units in Clearfield, Centre, and Clinton Counties, Pennsylvania: Pennsylvania Geological Survey, 4th ser., Map 12.

Peters, F.A., Johnson, P.W., and Kirby, R.C., 1962, Methods for producing alumina from clay, an evaluation of the sulfurous acid-caustic purification process: U.S. Bureau of Mines Report of Investigations $5997,21 \mathrm{p}$
Petrick, Alfred, Jr., Bennett, H.J., Starch, K.E., and Weisner, R.C., 1973, The economics of byproduct metals (in two parts), 1. Copper system: U.S. Bureau of Mines Information Circular 8569, $105 \mathrm{p}$.

Petrov, V.P., 1969 [Kaolin deposits of the USSR]: International Geological Congress Report of the Twenty-Third Session, Czechoslovakia, 1968, Proceedings of Symposium I, Kaolin Deposits of the World, A-Europe, p. 289-319. (In Russian.)

Philippines Bureau of Mines, 1978, Extraction of alumina from Batag Island, northern Samar clay: Philippines Bureau of Mines Annual Report, 1977, p. 17-18.

Phillips, C.V., and Wills, K.J., 1979, Review of methods available for extraction and production of smelter-grade alumina from United Kingdom indigenous resources, with particular reference to the micaceous residues of the china clay industry: Institution of Mining and Metallurgy (London) Transactions, Sec. C, v. 88, p. C153-C160.

Phinney, W.C., 1968, Anorthosite occurrences in Keweenawan rocks of northeastern Minnesota, in Isachsen, Y.W., ed., Origin of anorthosite and related rocks: New York State Museum and Science Service Memoir 18, p. 135-147.

1969, The Duluth Complex in the Gabbro Lake quadrangle, Minnesota: Minnesota Geological Survey Report of Investigations $9,20 \mathrm{p}$.

1972a, Northern prong, Duluth Complex, in Sims, P.K., and Morey, G.B., eds., Geology of Minnesota, a centennial volume: St. Paul, Minn., Minnesota Geological Survey, p. 346-353. 1972b, Northwestern part of Duluth Complex in Sims, P.K., and Morey, G.B., eds., Geology of Minnesota, a centennial volume: St. Paul, Minn., Minnesota Geological Survey, p. 335-345.

Piros, R.J., Jr., 1956, Recovery of alumina, phosphates, and uranium from phosphate ores: U.S. Patent 2,767,046, assigned to U.S. Atomic Energy Commission.

Pirsson, L.V., 1905, Petrography and geology of the igneous rocks of the Highwood Mountains, Montana: U.S. Geological Survey Bulletin $237,208 \mathrm{p}$.

Plummer, N.V., and Romary, J.F., 1947, Kansas clay, Dakota Formation: Kansas Geological Survey Bulletin 67, 241 p.

Ponomarev, V.D., and Sazhin, V.S., 1959, Mechanism of the decomposition of nephelines by alkaline solutions: Journal of Applied Chemistry of the USSR, v. 31, no. 8, p. 1134-1139. (Translated from Zhurnal Prikladnoi Khimii, 1958, v. 31, no. 8, p. 1143-1149.)

Porter, J.L., 1957, Extraction of alumina from aluminum phosphate ores: U.S. Patent 2,812,239, assigned to Kaiser Aluminum and Chemical Corporation.

1959, Calcium aluminate and alumina from phosphate ores: U.S. Patent 2,908,338, assigned to Kaiser Aluminum and Chemical Corporation.

Potter, M.J., 1980, Kyanite and related minerals, in Mineral facts and problems, 1980 edition: U.S. Bureau of Mines Bulletin 671, p. $481-491$.

1982, Kyanite and related minerals: U.S. Bureau of Mines Minerals Yearbook 1981, v. 1, p. 505-508.

1985, Kyanite and related minerals, in Mineral facts and problems, 1985 edition: U.S. Bureau of Mines Bulletin 675, p. 425-432. 1988, Kyanite and related materials: U.S. Bureau of Mines Minerals Yearbook 1986, v. 1, p. 573-575.

Prats, Michael, 1970, Recovering oil and dawsonite from oil shale: U.S. Patent 3,502,372, assigned to Shell Oil Company, $4 \mathrm{p}$.

Quinn, A.W., 1937, Petrology of the alkaline rocks at Red Hill, New Hampshire: Geological Society of America Bulletin, v. 48, no. 3, p. 373-401.

Quon, D.H.H., 1976, Extraction of alumina from Canadian and American anorthosite by the lime-soda-sinter process: Canada Centre for Mineral and Energy Technology CANMET Report 76-26, 31 p. 
Radcliffe, Dennis, 1976, Kyanite: Mining Engineering, v. 28, no. 3, p. $39-40$.

Raddatz, A.E., Gomes, J.M., and Wong, M.M., 1981, Laboratory investigation of sulfurous acid leaching of kaolin for preparing alumina: U.S. Bureau of Mines Report of Investigations 8533, 15 p.

Rado, T.A., 1981, Production of aluminum chloride and related products: U.S. Patent 4,283,371, assigned to Kerr-McGee Corporation, $7 \mathrm{p}$.

Rao, Y.K., and Soleiman, M.K., 1983, Catalytic chlorination of alumina: U.S. Bureau of Mines Open File Report 112-84, 59 p.

Ray, S.S., and Parker, F.G., 1977, Characterization of ash from coal-fired power plants: U.S. Environmental Protection Agency Report EPA-600-7-77-010.

Raza, H.A., and Iqbal, M.W.A., 1977, Mineral deposits, in Shah, S.M.I., ed., Stratigraphy of Pakistan: Pakistan Geological Survey Memoirs, v. 12, p. 98-120.

Read, W.A., and Dean, J.M., 1978, High-alumina fireclays in the Passage Group of the Clackmannan syncline, Scotland: Great Britain Institute of Geological Sciences Report 78/12, $21 \mathrm{p}$.

Redden, J.A., and Norton, J.J., 1975, Precambrian geology of the Black Hills, in Mineral and water resources of South Dakota: U.S. Congress, 94th, 2d session, Senate Committee on Interior and Insular Affairs, Committee Print, p. 21-28.

Redlich, Otto, and others, 1946, Extraction of alumina from clay: Industrial and Engineering Chemistry, v. 38, p. 1181-1187.

Rehim, A.A., 1974, Extraction of alumina from nepheline syenite: Annales Universitatis Scientiarum Budapestinensis de Rolando Eotvos Nominatae, Sectio Geologica, 1973, v. 17, p. 249-258.

Reynolds, J.E., and Williams, A.R., 1981, Process for chlorinating clays and bauxite: U.S. Patent 4,288,414, assigned to Public Service Company of Albuquerque, New Mexico.

Ridgway, J.M., 1982, Common clay and shale: Great Britain Institute of Geological Sciences, Mineral Resources Consultative Committee, Mineral Dossier 22, $164 \mathrm{p}$.

Riley, J.M., Edlund, V.E., and Nissen, W.I., 1983, Shaft furnace reduction-oxidation roasting of pelletized alunite dust: U.S. Bureau of Mines Report of Investigations 8821, $21 \mathrm{p}$.

Ripley, L.G., 1976, Extraction of alumina from Canadian anorthosite by the lime-sinter process: Canada Centre for Mineral and Energy Technology CANMET Report MRP/MSL 76-299(IR), $51 \mathrm{p}$.

1979a, Extraction and recovery of alumina from fly ash by hydrochloric acid-hydrofluoric acid leaching: Canada Centre for Mineral and Energy Technology CANMET Report MRP/MSL 79-62(IR), $40 \mathrm{p}$.

1979b, Extraction of alumina from Hat Creek coaly waste by the modified lime-sinter process: Canada Centre for Mineral and Energy Technology CANMET Report MRP/MSL 79-101(IR), $39 \mathrm{p}$.

Robb, W.A., and Smith, J.W., 1974, Mineral profile of oil shales in Colorado core hole No. 1, Piceance Creek basin, Colorado, in Murray, D.K., ed., Energy resources of the Piceance Creek basin, Colorado: Rocky Mountain Association of Geologists Field Conference, 25th, Guidebook, p. 91-100.

Robb, W.A., Smith, J.W., and Trudell, L.G., 1978, Mineral and organic distributions and relationships across the Green River Formation's saline depositional center, Piceance Creek basin, Colorado: U.S. Department of Energy, Laramie Energy Technology Center, Report of Investigation 78/6, $44 \mathrm{p}$.

Roberson, M.L., and others, 1977, Bayer process production of alumina: U.S. Patent 4,036,931, assigned to Kaiser Aluminum and Chemical Corporation, $8 \mathrm{p}$.

Robl, T.L., and Bland, A.E., 1977, The distribution of aluminum in shales associated with the major economic coal seams of eastern Kentucky, in Rose, J.G., ed., Proceedings, Third Kentucky Coal
Refuse Disposal and Utilization Seminar, May 11-12, 1977, Lexington, Ky.: Lexington, Ky., University of Kentucky, p. 97-101. Rocky Mountain News, 1972, Anorthosite deposit purchased by Alcoa: Rocky Mountain News, Denver, Colo., June 28, p. 85.

Rothrock, E.P., 1944, Mineral resources, Part 3 of A geology of South Dakota: South Dakota Geological Survey Bulletin 15, 255 p.

Roy, W.R., Thiery, R.G., Schuller, R.M., and Suloway, J.J., 1981, Coal fly ash-A review of the literature and proposed classification system with emphasis on environmental impacts: Illinois Geological Survey Environmental Geology Notes, no. 96, 69 p.

Royce, D.V., Jr., and Drown, H.L., 1974, Process for the crystallization of aluminum nitrate nonahydrate: U.S. Patent 3,804,598, assigned to Reynolds Metals Company.

Russ, W., 1924, The phosphate deposits of Abeokuta Province: Nigeria Geological Survey Bulletin 7, $43 \mathrm{p}$.

Russell, A.S., 1981, Pitfalls and pleasures in new aluminum process development: Metallurgical Transactions B, v. 12B, p. 203-215.

Ryder, Graham, Malcuit, R.J., and Vogel, T.A., 1975, Differentiation of an andesine-type anorthosite; the San Gabriel suite: Lithos, v. 8, no. 4, p. 311-316.

Sahama, T.G., 1952, Leucite, potash nepheline, and clinopyroxene from volcanic lavas from southwestern Uganda and adjoining Belgian Congo: American Journal of Science, Bowen Volume, pt. 2, p. 457-470.

St. Clair, H.W., and others, 1959, Operation of experimental plant for producing alumina from anorthosite: U.S. Bureau of Mines Bulletin $577,127 \mathrm{p}$.

Sakamoto, Takao, 1951, Aluminous shale; geology and mineral resources of Far East, Manchuria: Tokyo Geographic Society [Journal?], v. 6, pt. 8a, Metallic ore deposits. (Translated into English by the U.S. Army Corps of Engineers, April 1958.)

Sancho, J.P., Iglesias, J.G., Brime, C., and Verdeja, L.F., 1981, Mechanical activation of non bauxitic aluminous ores: Comité International pour l'Étude des Bauxites, de l'Alumine et de l'Aluminium Travaux, no. 16, p. 71-82.

Sancho, J.P., Verdeja, L.F., Encinas, M., and Brime, C., 1981, Some new contributions on the processing of non bauxitic aluminous ores: Comité International pour l'Étude des Bauxites, de l'Alumine et de l'Aluminium Travaux, no. 16, p. 83-97.

Sarbu, N., Sarbu, M., and Hollo, I., 1981 [Extracting alumina from nonbauxitic materials]: Metalurgia (Bucharest), v. 33, no. 5, p. 254-255. (In Romanian.)

Sato, M., and others, 1956, Aluminum, in Japan Geological Survey, Geology and mineral resources of Japan: Kawasaki-shi, p. 197-198.

Sawyer, D.L., Jr., and Turner, T.L., 1985, Pressure leaching alumina from raw kaolinitic clay using hydrochloric acid: U.S. Bureau of Mines Report of Investigations 8978, $18 \mathrm{p}$.

Sawyer, D.L., Jr., Turner, T.L., and Hunter, D.B., 1983, Alumina miniplant operations-Overall mass balance for clay- $\mathrm{HCl}$ acid leaching: U.S. Bureau of Mines Report of Investigations 8759, $29 \mathrm{p}$.

Schaller, J.L., Hunter, D.B., and Sawyer, D.L., Jr., 1982, Alumina miniplant operations-Production of misted raw kaolin feed: U.S. Bureau of Mines Report of Investigations 8712, $20 \mathrm{p}$.

Scheid, V.E., 1946, Preliminary report, Excelsior high-alumina clay deposit, Spokane County, Washington: U.S. Geological Survey Open-File Report, 66 p.

1947, Excelsior surface, an intra-Columbia River basalt weathering surface [abs.]: Geological Society of America Bulletin, v. 58, no. 12 , pt. 2 , p. 1224-1225.

Scheid, V.E., and Sohn, I.G, 1946, Preliminary report, Deary highalumina clay deposit, Latah County, Idaho: U.S. Geological Survey Open-File Report, 38 p. 
Schmidt-Collerus, J.J., and Hollingshead, R.D., 1968, Investigations into the nature of dawsonite in the Green River formations: Colorado School of Mines Quarterly, v. 63, no. 4, p. 143-167.

Schultz, A.R., and Cross, Whitman, 1912, Potash-bearing rocks of the Leucite Hills, Sweetwater County, Wyoming: U.S. Geological Survey Bulletin 512, $39 \mathrm{p}$.

Scofield, N.L., 1975, Layered series of the Wichita Complex, Oklahoma: Geological Society of America Bulletin, v. 86, no. 6, p. $732-736$.

Scott, T.R., 1962, Alumina by acid extraction: Journal of Metals, v. 14, no. 2, p. 121-125.

Seeley, F.G., and others, 1981, Determination of extraction equilibriums for several metals in the development of a process designed to recover aluminum and other metals from coal combustion ash: Hydrometallurgy, v. 6, nos. 3-4, p. 277-290.

Sever, C.W., Catheart, J.B., and Patterson, S.H., 1967, South Georgia Minerals Program-Project Report 7, Phosphate deposits of south-central Georgia and north-central peninsular Florida: Atlanta, Georgia Department of Mines, Mining and Geology, $62 \mathrm{p}$.

Seyfried, W.R., 1949, The ammonium sulphate process for the extraction of alumina from clay and its application in a plant at Salem, Oregon: American Institute of Mining and Metallurgical Engineers Transactions, v. 182, p. 39-50.

Shaaban, A.S., 1971, A laboratory investigation of the technological feasibility of extraction of alumina and production of commercial alums from Wadi Kalabsha kaolin deposit, in Said, Kushdi, and Mansour, A.O., eds., The discovery of a new kaolin deposit in Wadi Kalabsha, Nubia, Egypt: Egypt Geological Survey and Mining Authority Paper 54, p. 129-138.

Shabad, Theodore, 1976a, Raw material problems of the Soviet aluminium industry: Resources Policy, v. 2, no. 4, p. 222-234. 1976b, Soviet experiment in aluminum fails: The New York Times, Sunday, May 8th, sec. 3, p. 5.

Shafer, H.E., Jr., and Solomon, J.A., 1967, The effect of selected calcining temperatures on alumina extraction from coal-associated draw-slate: American Institute of Mining, Metallurgical, and Petroleum Engineers, Society of Mining Engineers, Transactions, v. 238, p. 101-103.

Shaikh, N.A., 1977, Non-bauxite sources of alumina in Scandinavia and Finland, in Fleming, R.F.S., ed., Proceedings of the 2nd 'Industrial Minerals' International Congress, Munich, 1976: London, Metal Bulletin Ltd., p. 189-198.

Shanks, D.E., Eisele, J.A., and Bauer, D.J., 1981, Hydrogen chloride sparging crystallization of aluminum chloride hexahydrate: U.S. Bureau of Mines Report of Investigations 8593, $15 \mathrm{p}$.

Shawe, D.R., 1956, Significance of roll ore bodies in genesis of uranium-vanadium deposits on the Colorado Plateau, in Page, L.R., Stocking, H.E., and Smith, H.B., comps., Contributions to the geology of uranium and thorium by the United States Geological Survey and Atomic Energy Commission for the United Nations International Conference on Peaceful Uses of Atomic Energy, Geneva, Switzerland, 1955: U.S. Geological Survey Professional Paper 300, p. 239-241.

Shul'gin, L.P., Kochetkova, R.D., and Petrova, V.I., 1975 [Treatment with alkaline solutions of the product from sintering kyanite with sodium carbonate], in Shul'gin, L.P., ed., Khimiya $i$ khimicheskaya tekhnologia mineral'nogo syr'ya [Chemistry and chemical technology of mineral raw materials]: Kirovsk, Akademiya Nauk SSSR, Kol'skiy Filial, p. 8-12. (In Russian. Article not seen by authors; information from Chemical Abstracts, 1977 , v. 86 , abstract 173695 .)

Singleton, E.L., Kirby, D.E., and Sullivan, T.A., 1968, Electrowinning aluminum from aluminum chloride, operation of a twocompartment cell: U.S. Bureau of Mines Report of Investigations $7212,15 \mathrm{p}$.
Sivarajasingham, S., Alexander, L.T., Cady, J.G., and Cline, M.G., 1962, Laterite, in Advances in agronomy, v. 14: New York, Academic Press, p. 1-60.

Size, W.B., 1973, Petrology of the Red Hill syenitic complex, New Hampshire: University of Hawaii Institute of Geophysies Contributions, 1972 , p. 445-458.

Slansky, M., Lallemand, A., and Millot, G., 1964, La sédimentation et l'altération latéritique des formations phosphatées du gisement de Taïba (République du Sénégal): Alsace-Lorraine Service de le Carte Géologique Bulletin, v. 17, no. 4, p. 311-324.

Smith, J.W., 1980, Alumina from oil shale: American Institute of Mining, Metallurgical, and Petroleum Engineers Preprint 80-62, $8 \mathrm{p}$.

Smith, J.W., Beard, T.N., and Wade, P.M., 1972, Estimating nahcolite and dawsonite content of Colorado oil shale from oil-yield assay data: U.S. Bureau of Mines Report of Investigations 7689, 24 p.

Smith, J.W., and Milton, Charles, 1966, Dawsonite in the Green River Formation of Colorado: Economic Geology, v. 61, no. 6, p. 1029-1042.

Smith, J.W., and Young, N.B., 1969, Determinations of dawsonite and nahcolite in Green River Formation oil shales: U.S. Bureau of Mines Report of Investigations 7286, $20 \mathrm{p}$.

-1975, Dawsonite-Its geochemistry, thermal behavior, and extraction from Green River oil shale: Colorado School of Mines Quarterly, v. 70, no. 3, p. 69-93.

Smith, K.M., 1949, Investigation of the Aiken kaolin district, Aiken County, S.C.: U.S. Bureau of Mines Report of Investigations $4606,35 \mathrm{p}$.

Smith, R.W., 1929, Sedimentary kaolins of the Coastal Plain of Georgia: Georgia Geological Survey Bulletin 44, 482 p.

-1931, Shales and brick clays of Georgia: Georgia Geological Survey Bulletin 45, $348 \mathrm{p}$.

Smorgunenko, N.S., and Vlasov, V.V., 1981, Processing alunite with the use of sulfuric acid to produce alumina, sulfuric acid, potassium sulfate and other products by VAMI method: Comité International pour l'Étude des Bauxites, de l'Alumine et de l'Aluminium Travaux, no. 16, p. 65-69.

Snavely, P.D., Jr., and Wagner, H.C., 1961, Differentiated gabbroic sills and associated alkalic rocks in the central part of the Oregon Coast Range, Oregon: U.S. Geological Survey Professional Paper 424-D, p. D156-D161.

Sohn, H.Y., 1983, The use of coal wastes for the production of alumina: U.S. Bureau of Mines Open File Report 139-84, 71 p.

Sohn, I.G., 1952, Geologic environment map of alumina resources of the Columbia Basin: U.S. Geological Survey Resource Map MR-1, scale 1:1,500,000.

Sorensen, R.T., 1982, Alumina miniplant operations-Removal of iron from aluminum nitrate pregnant liquor by solvent extraction: U.S. Bureau of Mines Open File Report 64-83, 19 p.

Sorensen, R.T., Amey, E.B., III, and Sawyer, D.L., 1981, The removal of iron from aluminum chloride leach liquor by solvent extraction: U.S. Bureau of Mines Report of Investigations 8560, $28 \mathrm{p}$.

Sorensen, R.T., and Sawyer, D.L., Jr., 1984, Alumina miniplant operations-Separation of aluminum chloride liquor from leach residue by horizontal belt filtration: U.S. Bureau of Mines Report of Investigations $8831,44 \mathrm{p}$.

Sorensen, R.T., Sawyer, D.L., Jr., and Turner, T.L., 1983, Alumina miniplant operations-Separation of aluminum chloride liquor from leach residue solids by classification and thickening: U.S. Bureau of Mines Report of Investigations 8805, $23 \mathrm{p}$.

Sorensen, R.T., and Schaller, J.L., 1983, Evaluation of alumina extraction from coal waste-Composition and availability: U.S. Bureau of Mines Information Circular 8940, $19 \mathrm{p}$. 
Sotka, Pentti, and Soderholm, Bengt, 1980, Alumiinituotanto ja Suomen potentiaaliset alumiinin raaka-aineet [World aluminum production and its potential raw materials in Finland]: Vuoriteollisuus-Bergshanteringen, v. 38, no. 1, p. 23-26. (English summary.)

Souza Santos, Persio de, 1976, New sedimentary kaolin deposits in the Amazon region; Jarí and Capim Rivers, Brazil [abs.], in Bailey, S.W., ed., Proceedings of the International Clay Conference, Mexico City, Mexico, July 16-23, 1975: Wilmette, Ill., Applied Publishing Ltd., p. 553.

Specketer, H., Münch, G., and Rossteutscher, F., 1924, Production of pure alumina: U.S. Patent $1,519,880$, assigned to a German company through American Lurgi Corporation.

Spedden, H.R., and Schellinger, A.K., 1969a, Continuous hydrolysis of copper leaching solutions to decrease the multivalent ion content and increase the acidity: U.S. Patent $3,436,177$, assigned to Kennecott Copper Corporation, $5 \mathrm{p}$.

-1969 b, High-purity alumina: U.S. Patent $3,436,176$, assigned to Kennecott Copper Corporation, $4 \mathrm{p}$.

Spence, G.M., 1961, Sodium aluminate from alumina-containing minerals in sintering: U.S. Patent 2,973,244, assigned to Monolith Portland Midwest Company.

Spicer, T.S., 1971, Pennsylvania anthracite refuse-A summary of a literature survey on utilization and disposal: Pennsylvania State University, Coal Research Section, Special Report SR-79.

Stanfield, K.E., Rose, C.K., McAuley, W.S., and Tesch, W.J., Jr., 1957, Oil yields of sections of Green River oil shale in Colorado, 1952-54: U.S. Bureau of Mines Report of Investigations 5321, $132 \mathrm{p}$.

Stanin, S.A., and Cooper, B.R., 1968, The Mt. Montro kyanite deposit, Grand Bassa County, Liberia: Liberia Geological Survey Bulletin $2,20 \mathrm{p}$.

Stankovich, I.D., 1978, The aluminium industry in the Soviet Union: London, Metal Bulletin Ltd., 62 p.

Staufer, Richard, and Konopicky, Kamillo, 1934, Alumina from argillaceous material: U.S. Patent 1,956,139, assigned to Alterra A.-G.

Stevenson, J.S., and Stevenson, L.S., 1978, Contrasting dawsonite occurrences from Mont St-Bruno, Quebec: Canadian Mineralogist, v. 16 , pt. 3, p. $471-474$.

Störr, M., Schwerdtner, G., and Buchwald, J., 1969, Kaolinlagerstatten der Deutschen Demokratischen Republik: International Geological Congress Report of the Twenty-Third Session, Czechoslovakia, 1968, Proceedings of Symposium I, Kaolin Deposits of the World, A-Europe, p. 107-140.

Stout, Wilber, Stull, R.T., McCaughey, W.J., and Demorest, D.J., 1923, Coal-formation clays of Ohio: Ohio Geological Survey, 4th ser., Bulletin 26, 588 p.

Stow, S.H., 1968, The heavy minerals of the Bone Valley Formation and their potential value: Economic Geology, v. 63, no. 8, p. 973-975.

Sukhanova, N.N., and Ponomarev, V.D., 1969 [Production of aluminum sulfate solutions from Ekibastuz coal beneficiation wastes]: Akademiya Nauk Kazakhskoi SSR, Khimiko-Metallurgicheskogo Instituta, Trudy, v. 7, p. 138-143. (In Russian. Article not seen by authors; information from Chemical Abstracts, 1970, v. 73, abstract 79018a.)

Sun, S.-C., Chao, Tze, Hirsh, William, and Freed, B.A., 1967, The extraction of alumina and the removal of iron from Pennsylvania aluminous clays: Pennsylvania State University, College of Earth and Mineral Sciences, Earth and Mineral Sciences, v. 37, no. 3, p. 21-24.

Sun, S.-C., Vasquez-Rosas, H., and Augenstein, D., 1971, Pennsylvania anthracite refuse-A literature survey on the chemical elements in coal and coal refuse: Pennsylvania State University, Coal Research Section, Special Report SR-83.
Swadley, W C, 1958, Petrology of the Christmas Mountains Gabbro, Brewster County, Texas: Austin, Tex., University of Texas, unpub. M.A. thesis.

Sweet, P.C., 1973, Analyses of clay, shale, and related materials-Southern counties: Virginia Division of Mineral Resources, Mineral Resource Report 12, $183 \mathrm{p}$.

Tackett, J.E., Jr., 1970, Oil shale processing; extraction of dawsonite: U.S. Patent 3,503,705, assigned to Marathon Oil Company, 2 p.

Tallon, W.A., and Hunter, R.G., 1959, High-aluminum clays of West Virginia: West Virginia Geological and Economic Survey Report of Investigations 17, $49 \mathrm{p}$.

Tardy, Yves, 1969, Géochimie des altérations-Étude des arènes et des eaux de quelques massifs cristallins d'Europe et d'Afrique: Alsace-Lorraine Service de la Carte Géologique Mémoire 31, $199 \mathrm{p}$.

Tardy, Yves, and Nahon, Daniel, 1985, Geochemistry of laterites, stability of $\mathrm{Al}$-goethite, Al-hematite, and $\mathrm{Fe}^{3+}$-kaolinite in bauxites and ferricretes-An approach to the mechanism of concretion formation: American Journal of Science, v. 285, no. 10, p. 865-903.

Taylor, R.B., 1964, Geology of the Duluth Gabbro Complex near Duluth, Minnesota: Minnesota Geological Survey Bulletin 44, $63 \mathrm{p}$.

Teague, K.H., 1950, Sillimanite in the Southeast: Mining Engineering, v. 187 , no. 7 , p. $785-789$.

Temperley, B.N., 1953, Kyanite in Kenya: Kenya Geological Survey Memoir 1, $87 \mathrm{p}$.

Temple, A.K., and Grogan, R.M., 1965, Carbonatite and related alkalic rocks at Powderhorn, Colorado: Economic Geology, v. 60, no. 4, p. $672-692$.

Templeton, C.C., 1971, Recovery of aluminum compounds and oil from oil shale formations: U.S. Patent 3,572,838, assigned to Shell Oil Company, $5 \mathrm{p}$.

Thomas, Gordon, and Ingraham, T.R., 1959, The alum-amine process for the recovery of alumina from shale: Canada Department of Mines and Technical Surveys, Mines Branch, Research Report $\mathrm{R} 45,25 \mathrm{p}$.

Thompson, A.M., 1975, Anorthosite in the Piedmont of northern Delaware [abs.]: Geological Society of America Abstracts with Programs, v. 7, no. 1, p. 124-125.

Thompson, R.M., 1944a, Geologic map of the principal clay area of Twiggs County, Georgia: U.S. Geological Survey Open-File Report.

-1944b, Geologic map of the principal clay area of Washington County, Georgia: U.S. Geological Survey Open-File Report.

Thorsen, G.W., 1966, High-alumina refractory materials, in Mineral and water resources of Washington: U.S. Congress, 89th, 2d session, Senate Committee on Interior and Insular Affairs, Committee Print, p. 219-224.

Tomilov, N.P., Berger, A.S., and Vorsina, I.A., 1971, Sinteticheskiy dausonit i yego fiziko-khimicheskiye kharakteristiki [Synthetic dawsonite and its physical and chemical characteristics]: Vsesyuznoye Mineralogicheskoye Obshchestvo Zapiski, v. 100, no. 3, p. 297-302.

Tomka, L., 1974, Technology of aluminium oxide production from low modulus bauxites by the sintering method: Comité International pour l'Étude des Bauxites, des Oxydes et des Hydroxydes d'Aluminium Travaux, no. 12, p. 195-211.

Toth, Charles, 1969, Production of aluminum: U.S. Patent 3,615,359, assigned to Applied Aluminum Research Corporation, $27 \mathrm{p}$. 1975, Aluminum by reduction of aluminum trichloride with manganese: U.S. Patent 3,918,960, assigned to Applied Aluminum Research Corporation, $8 \mathrm{p}$.

Tourtelot, H.A., 1962, Preliminary investigation of the geologic setting and chemical composition of the Pierre Shale, Great Plains region: U.S. Geological Survey Professional Paper 390, 74 p. 
1964, Bauxite deposits of the Tippah-Benton district, Mississippi: U.S. Geological Survey Bulletin 1199-C, 31 p.

Tracey, J.I., Jr., 1944, High-alumina clays of Pulaski and Saline Counties, Arkansas: American Ceramic Society Journal, v. 27, no. 8, p. 246-249.

Trudell, L.G., Beard, T.N., and Smith, J.W., 1970, Green River Formation lithology and oil shale correlations in the Piceance Creek basin, Colorado: U.S. Bureau of Mines Report of Investigations 7357, $212 \mathrm{p}$.

Turner, T.L., and Rogers, D.T., 1983, Alumina miniplant operationsEvaporative crystallization of aluminum nitrate nonahydrate from aluminum nitrate solutions: U.S. Bureau of Mines Report of Investigations $8830,29 \mathrm{p}$.

Turner, T.L., Sawyer, D.L., Jr., Hunter, D.B., and Amey, E.B., III, 1982, Alumina miniplant operations-Calcination of kaolin in a direct-fired rotary kiln: U.S. Bureau of Mines Report of Investigations $8736,24 \mathrm{p}$.

Upton, B.G.J., 1974, The alkaline province of south-west Greenland, in Sørensen, H., ed., The alkaline rocks: New York, John Wiley and Sons, p. 221-238.

U.S. Bureau of Mines, 1939, Aluminum: U.S. Bureau of Mines Mineral Trade Notes, v. 9, no. 6, p. 2-9.

1953, Materials survey, bauxite: U.S. Bureau of Mines [MS 3], [309] p.

-1965, Argentina: U.S. Bureau of Mines Mineral Trade Notes, v. 60 , no. 6 , p. 45 .

1967, Potential sources of aluminum: U.S. Bureau of Mines Information Circular 8335, $148 \mathrm{p}$.

1972a, An economic analysis of an oil shale, nahcolite, dawsonite complex in Colorado, Option II, circa 1971: U.S. Bureau of Mines Open File Report 32-72, 175 p.

1972b, An economic analysis of an oil shale, nahcolite, dawsonite complex in Colorado, Option III, circa 1971: U.S. Bureau of Mines Open File Report 33-72, 176 p.

U.S. Department of the Interior, 1968, Prospects for oil shale development-Colorado, Utah, and Wyoming: Washington, D.C., $134 \mathrm{p}$.

U.S. Energy Research and Development Administration, 1977, A bibliography of publications dealing with oil shale and shale oil from U.S. Bureau of Mines, 1917-1974, and the ERDA Laramie Energy Research Center, 1975-1976: U.S. Energy Research and Development Administration Report RI-77/7, $51 \mathrm{p}$.

Vachtl, Josef, 1969, Review of kaolin deposits of Europe: International Geological Congress Report of the Twenty-Third Session, Czechoslovakia, 1968, Proceedings of Symposium I, Kaolin Deposits of the World, A-Europe, p. 13-24.

Valentine, G.M., and Huntting, M.T., 1960, Nonmetallic minerals, pt. 1 of Inventory of Washington minerals: Washington Division of Mines and Geology Bulletin 37, 2d ed., 2 v. (v. 1, text, 175 p.; v. 2, maps, $83 \mathrm{p}$.)

Van Nordstrand, R.A., 1968, Recovery of aluminum from retorted shale and conversion of sodium aluminate to sodium aluminum carbonate hydroxide: U.S. Patent $3,389,975$, assigned to Sinclair Research, Inc., $4 \mathrm{p}$.

Van Noy, R.M., Petersen, N.S., and Gray, J.J., 1970, Kyanite resources in the northwestern United States: U.S. Bureau of Mines Report of Investigations 7426, $81 \mathrm{p}$.

Varley, E.R., 1965, Sillimanite [group]-Andalusite, kyanite, sillimanite: London, Great Britain Overseas Geological Surveys, 165 p.

Vereinigte Aluminium-Werke A.-G., 1955, Extracting aluminum from raw materials containing aluminum oxide: British Patent 763,709.

Visser, H.N., and Schoch, A.E., 1973, The geology and mineral resources of the Saldanha Bay area: South Africa Geological Survey Memoir 63, 150 p.
Volkova, A.N., and Rekshinskaya, L.G., 1975 [Epigenetic dawsonite of the Kuznetsk Basin Carboniferous formation], in Bushinskiy, G.I., ed., Problemy genezisa boksitov [Problems of bauxite genesis]: Moscow, Nauka, p. 303-308.

Waagé, K.M., 1950, Refractory clays of the Maryland coal measures: Maryland Department of Geology, Mines and Water Resources Bulletin 9, $182 \mathrm{p}$.

1953, Refractory clay deposits of south-central Colorado: U.S. Geological Survey Bulletin 993, 104 p.

-1961 , Stratigraphy and refractory clayrocks of the Dakota Group along the northern Front Range, Colorado: U.S. Geological Survey Bulletin 1102, $154 \mathrm{p}$.

Wade, Arthur, and Prider, R.T., 1940, The leucite-bearing rocks of the west Kimberley area, Western Australia: Geological Society of London Quarterly Journal, no. 381, v. 96, pt. 1, p. 39-98.

Walker, W.W., and Stevens, D.N., 1974, The Earth Sciences-National Steel-Southwire alunite-to-alumina project: American Institute of Mining, Metallurgical, and Petroleum Engineers, The Metallurgical Society, Preprint A74-64, p. 683-688.

Walton, B.J., 1973, The structure and stratigraphy of the anorthosite complex in the area north of Björnesund, near Fiskenaesset, in Progress report on the geology of the Fiskenaesset region, SouthWest Greenland: Grönlands Geologiske Undersögelse Rapport 51, p. $60-64$.

Ward, W.C., Jr., and Husted, J.E., 1977, Alumina from kaolin II: Atlanta, Georgia Institute of Technology, Engineering Experiment Station, $32 \mathrm{p}$.

Ward, W.C., Jr., Husted, J.E., Howard, W.C., and Collins, Amy, 1972, Alumina from kaolin potentials: Georgia Institute of Technology, Engineering Experiment Station, Project A-1343, 64 p.

Warren, W.C., 1943, Bauxite and kaolin deposits of Wilkinson County, Georgia: U.S. Geological Survey Open-File Report, 2 sheets.

Warren, W.C., Bridge, Josiah, and Overstreet, E.F., 1965, Bauxite deposits of Virginia: U.S. Geological Survey Bulletin 1199-K, $17 \mathrm{p}$.

Warren, W.C., and Clark, L.D., 1965, Bauxite deposits of the Eufaula district, Alabama: U.S. Geological Survey Bulletin 1199-E, 31 p.

Waugh, W.N., Hill, W.E., Jr., Galle, O.K., and Hladik, W.B., 1964, The amenability of Kansas clays to alumina extraction by hydrochloric acid treatment: Kansas Geological Survey Bulletin 170, pt. 7, $14 \mathrm{p}$.

Weed, W.H., and Pirsson, L.V., 1900, Geology of the Little Belt Mountains, Montana: U.S. Geological Survey Annual Report 20 (1898-99), pt. 3, p. 257-581.

Weichman, B.E., 1974a, Shale oil and mineral recovery: U.S. Patent $3,821,353$, assigned to Superior Oil Company, $12 \mathrm{p}$.

1974b, Some effects of the Rio Blanco project nuclear detonation on the leached zone in the Parachute Creek Member of the Green River Formation, in Murray, D.K., ed., Energy resources of the Piceance Creek basin, Colorado: Rocky Mountain Association of Geologists Field Conference, 25th, Guidebook, p. 205-215.

1976, Oil shale is not dead, in Gary, J.H., ed., Proceedings of the ninth Oil Shale Symposium: Colorado School of Mines Quarterly, v. 71 , no. 4 , p. $71-84$.

Wheeler, H.A., 1896, Clay deposits: Missouri Geological Survey, 1st Series, Report, v. 11, $622 \mathrm{p}$.

White, J.C., 1984, Domestic saprolites as potential substitutes for refractory-grade bauxite: U.S. Bureau of Mines Report of Investigations $8881,10 \mathrm{p}$.

White, J.C., Henry, J.L., and Krogh, C.J., 1982, Removal of organic contaminants from aluminum chloride solutions: U.S. Bureau of Mines Report of Investigations 8619, $17 \mathrm{p}$.

White, J.C., Henry, J.L., and Traut, D.E., 1982, Calcination of aluminum nitrate nonahydrate in a fluidized bed: U.S. Bureau of Mines Report of Investigations $8705,23 \mathrm{p}$. 
White, J.C., Mauser, J.E., and Henry, J.L., 1985, Reduction-grade alumina and soda ash from dawsonite oil shale section. Chemistry and process investigations, in Gary, J.H., ed., Eighteenth Oil Shale Symposium proceedings: Golden, Colo., Colorado School of Mines Press, p. 182-195.

White, W.A., comp., 1959, Chemical and spectrochemical analyses of Illinois clay materials: Illinois Geological Survey Circular 282, $55 \mathrm{p}$.

White, W.S., 1965, Bauxite deposits of the Warm Springs district, Meriwether County, Georgia: U.S. Geological Survey Bulletin 1199-I, $15 \mathrm{p}$.

White, W.S., and Denson, N.M., 1966, Bauxite deposits of northwest Georgia: U.S. Geological Survey Bulletin 1199-M, 42 p.

Wiedbrauck, Erich, and Büche, Karl, 1934, Process for the production of monobasic aluminum sulfite: U.S. Patent 1,971,668, assigned to Th. Goldschmidt A.-G.

1935, Decomposition of siliceous aluminous minerals: U.S. Patent 2,006,851, assigned to Th. Goldschmidt A.-G.

Wijatno, H., 1977, Aluminum recovery from coal fly ash by high temperature chlorination: Iowa State University, Ames Laboratory, Report IS-T-777, $88 \mathrm{p}$.

Williams, N.F., and Plummer, N.V., 1951, Clay resources of the Wilcox Group in Arkansas: Arkansas Division of Geology Information Circular 15, 98 p.

Wills, K.J., and Phillips, C.V., 1977, A review of the [United Kingdom] indigenous resources for aluminium: Camborne School of Mines Journal, v. 77, p. 57-60.

Wilmot, R.C., Sullivan, A.C., and Trought, M.E., 1960, Bauxite: U.S. Bureau of Mines Minerals Yearbook 1959, v. 1, p. 223-240.

Wilson, Hewitt, and Goodspeed, G.E., 1934, Kaolin and china clay in the Pacific Northwest: Washington University (Seattle) Engineering Experiment Station Bulletin 76, $188 \mathrm{p}$.

Windley, B.F., 1969, Anorthosites of southern west Greenland, in Kay, Marshall, ed., North Atlantic-Geology and continental drift: American Association of Petroleum Geologists Memoir 12, p. 899-915.

Winer, A.A., 1977, Sources of Canadian non-bauxite alumina, in Rose, J.G., ed., Proceedings, Third Kentucky Coal Refuse Disposal and Utilization Seminar, May 11-12, 1977, Lexington, Ky.: Lexington, Ky., University of Kentucky, p. 103-106.

Winer, A.A., and Quon, D.H.H., 1979, Non-bauxite sources of alumina in Canada-Extraction of alumina from anorthosite by alkali sintering: Comité International pour l'Étude des Bauxites, de l'Alumine et de l'Aluminium Travaux, no. 15, p. 209-222.

Winer, A.A., and Tibbetts, T.E., 1976, Shales and coal refuse for alumina production: Canada Centre for Mineral and Energy Technology CANMET Report MRP/MSL 76-168(OP).
1978, Coal associated materials as potential non-bauxite sources of alumina: Canada Centre for Mineral and Energy Technology CANMET Report 78-31, $14 \mathrm{p}$.

Winston-Salem Journal, 1971, Newspapers win Pulitzer Prize: Winston-Salem Journal (North Carolina), May 4th, p. 1.

Wise, W.D., 1971, Removal of chromium from aluminum nitrate solutions containing iron oxide: U.S. Patent $3,615,183$, assigned to Reynolds Metals Company, $4 \mathrm{p}$.

Wolff, J.E., 1938, Igneous rocks of the Crazy Mountains, Montana: Geological Society of America Bulletin, v. 49, no. 10, p. 1569-1626.

Woody, R.J., 1943, Bibliography literature on the extraction of alumina from clay with short discussions: Washington State Mining Experiment Station Bulletin E-1, 31 p.

World Mining, 1980, Italy: World Mining, v. 33 , no. 4, p. 87.

Wright, L.A., 1957, Kyanite, andalusite, and related minerals, in Wright, L.A., ed., Mineral commodities of California: California Division of Mines Bulletin 176, p. 275-280.

Yates, R.G., and Thompson, G.A., 1959, Geology and quicksilver deposits of the Terlingua district, Texas: U.S. Geological Survey Professional Paper 312, $114 \mathrm{p}$.

Yodis, A.W., and Schnoor, W.G., 1968, Process for producing highpurity aluminum nitrate solutions from low-grade aluminous ores of intermediate iron content: U.S. Patent $3,415,618$, assigned to Allied Chemical Corporation.

Young, N.B., and Smith, J.W., 1970, Dawsonite and nahcolite analyses of Green River Formation oil-shale sections, Piceance Creek basin, Colorado: U.S. Bureau of Mines Report of Investigations 7445, $22 \mathrm{p}$.

Young, N.B., Smith, J.W., and Robb, W.A., 1975, Determination of carbonate minerals of Green River Formation oil shales, Piceance Creek basin, Colorado: U.S. Bureau of Mines Report of Investigations $8008,41 \mathrm{p}$.

Zanin, Y.N., Krivoputskaya, L.M., and Zamirailova, A.G., 1977 [Highalumina minerals in the supergene phosphorites of the Dzhanytas ore deposits in the Karatau Basin]: Geologiya i Geofizika, v. 18, no. 9, p. 143-146. (English translation by Allerton Press in Soviet Geology and Geophysics, 1978, v. 18, no. 9, p. 113-115.)

Zapp, A.D., 1943, Andersonville bauxite district, Georgia: U.S. Geological Survey Open-File Report, 1 sheet. 1949, Geology of the Andersonville bauxite district, Georgia: U.S. Geological Survey Open-File Report, $60 \mathrm{p}$.

1965, Bauxite deposits of the Andersonville district, Georgia: U.S. Geological Survey Bulletin 1199-G, 37 p.

Zapp, A.D., and Clark, L.D., 1965, Bauxite in areas adjacent to and between the Springvale and Andersonville districts, Georgia: U.S. Geological Survey Bulletin 1199-H, 10 p.

Zen, E-an, and Hammarstrom, J.G., 1975, Quantitative determination of dawsonite in Green River shale by powder-sample X-ray diffraction-Effect of grinding: U.S. Geological Survey Journal of Research, v. 3, no. 1, p. 21-30. 



\section{Geology and Resources of Aluminum}

A. World Nonbauxite Aluminum Resources-Alunite

By ROBERT B. HALL

B. World Bauxite Resources

By SAM H. PATTERSON, HORACE F. KURTZ, JANE C. OLSON, and CATHY L. NEELEY

C. World Nonbauxite Aluminum Resources Excluding Alunite By JOHN W. HOSTERMAN, SAM H. PATTERSON, and ELIZABETH E. GOOD

U.S. GEOLOGICAL SURVEY PROFESSIONAL PAPER 1076

This volume was published as separate chapters $A-C$

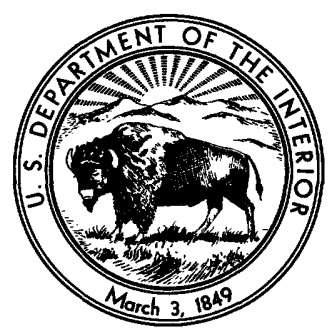




\section{DEPARTMENT OF THE INTERIOR}

MANUEL LUJAN, Jr., Secretary

\section{U.S. GEOLOGICAL SURVEY}

Dallas L. Peck, Director

Any use of trade, product, or firm names in this publication is for descriptive purposes only and does not imply endorsement by the U.S. Government 


\section{CONTENTS}

[Letters designate the separately published chapters]

(A) World Nonbauxite Aluminum Resources-Alunite, by Robert B. Hall.

(B) World Bauxite Resources, by Sam H. Patterson, Horace F. Kurtz, Jane C. Olson, and Cathy L. Neeley.

(C) World Nonbauxite Aluminum Resources Excluding Alunite, by John W. Hosterman, Sam H. Patterson, and Elizabeth E. Good. 